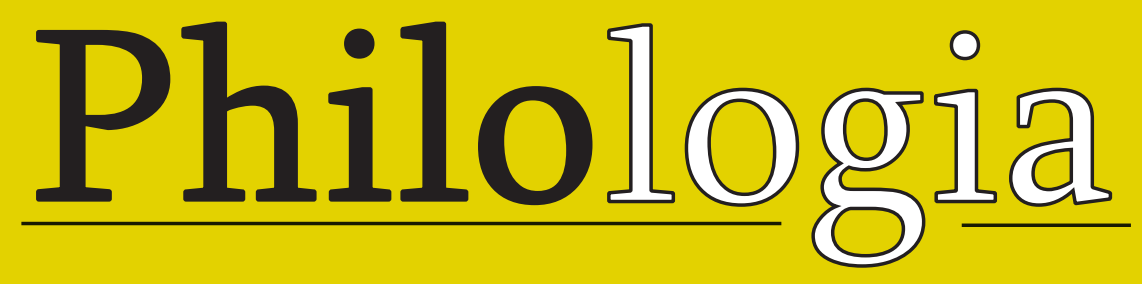

LXIII 

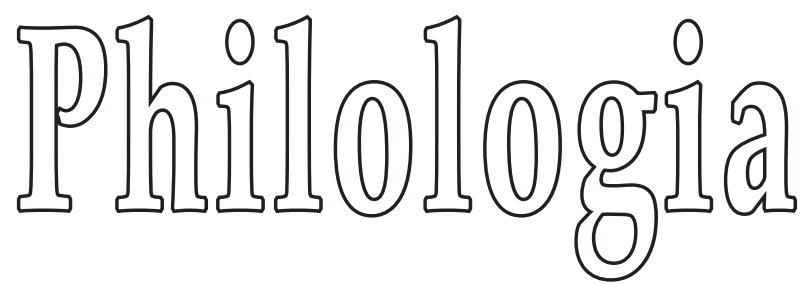

LXIII

https://doi.org/10.52505/1857-4300.2021.2(314)

\section{Revista Philologia este indexată în:}

\section{ERIHPLUS}

INFOBASE INDEX

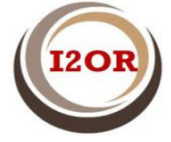

INSTITUTUL

CULTURAL

$\mathrm{R} \cap \mathrm{M} \hat{A} \mathrm{~N}$
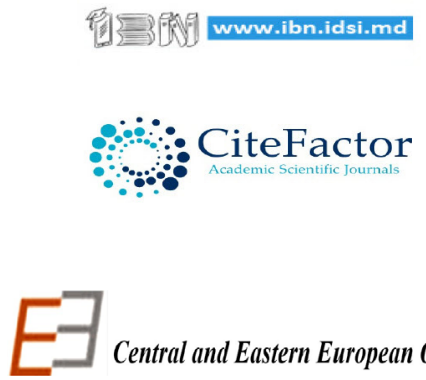

Central and Eastern European Online Library
STW WorldCat'

ULRICHSWEB"

GLOBAL SERIALS DIRECTORY

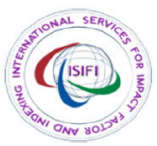

Revista apare cu sprijinul Institutului Cultural Român din Bucureşti

Revista este editată în cadrul proiectului 20.80009.1606.01 Valorificarea științifică a patrimoniului lingvistic național în contextul integrării europene

Fondator: Institutul de Filologie Română „Bogdan Petriceicu-Hasdeu”

Înregistrată la Camera Naţională a Cărţii la 19.05.2010, nr. 4300-1948-1905

\section{Publicaţie ştiinţifică recenzată}

Categoria „B”

Revista Philologia este moştenitoarea de drept şi continuatoarea publicaţiilor Limba şi Literatura moldovenească (1958-1989) şi Revistă de lingvistică şi ştiinţă literară (1990-2009).

Articolele se vor trimite pe adresa de e-mail: philologia.if@gmail.com

Orice material publicat în Philologia reflectă punctul de vedere al autorului.

Responsabilitatea pentru conţinutul fiecărui articol aparţine în exclusivitate semnatarului. Drepturile de autor asupra articolelor publicate aparțin semnatarilor.

CC Institutul de Filologie Română „Bogdan Petriceicu-Hasdeu” al MECC, 2021 


\section{COLEGIUL DE REDACȚIE \\ REDACTORI-SEFI:}

dr. Viorica RĂILEANU

dr. Marian Gheorghe SIMION
Institutul de Filologie Română „B. P.-Hasdeu”, Chișinău, Republica Moldova

Universitatea Harvard; Institutul pentru Studii de Pace în Creștinismul Răsăritean, SUA

\section{REDACTORI ADJUNCTI:}

dr. Ana VULPE, Institutul de Filologie Română „B. P. -Hasdeu”, Chişinău, Republica Moldova

dr. hab. Ion PLĂMĂDEALĂ, Institutul de Filologie Română „B. P. -Hasdeu”, Chișinău, Republica Moldova

\section{DIRECTOR ONORIFIC:}

dr. hab. Vasile BAHNARU, Institutul de Filologie Română „B. P. -Hasdeu”, Chișinău, Republica Moldova

\section{Acad. Mihai CIMPOI}

Academia de Științe a Moldovei, Institutul de Filologie Română „B. P.-Hasdeu”,

Chișinău, Republica Moldova

\section{Acad. Eugen SIMION}

Academia Română, Institutul de Istorie

şi Teorie Literară „G. Călinescu”,

București, România

\section{M. c. Gheorghe CHIVU}

Academia Română, Universitatea din București, România

\section{Dr. Ioan-Gheorghe ROTARU}

Institutul Teologic Creștin după Evanghelie

„Timotheus” din București, România

\section{Dr. Oana URSACHE}

Universitatea din Granada, Spania

\section{Dr. Brîndușa STERPU}

Institutul Naţional de Cercetări Economice,

Academia Română, București, România

\section{Dr. Mihai COVACI}

Universitatea „Hiperion”, București, România

Dr. hab. Gheorghe POPA

Universitatea de Stat „Alecu Russo” din Bălţi,

Republica Moldova

\section{Dr. Bogdan CREŢU}

Institutul de Filologie Română „A. Philippide”,

Academia Română, Filiala Iaşi, România

\section{Dr. Eugenia BOJOGA}

Universitatea „Babeș-Bolyai”, Cluj-Napoca, România;

Pontifico Instituto Orientale, Vatican

\section{Dr. Adrian TUDURACHI}

Institutul de Lingvistică şi Istorie Literară

„Sextil Puşcariu”, Cluj-Napoca, România

\section{MEMBRI:}

Dr. Silvia PITIRICIU

Universitatea din Craiova, România

Dr. Sorin ALEXANDRESCU

Universitatea din București, România

Dr. Eugen MUNTEANU

Institutul de Filologie Română „A. Philippide”, Iaşi, România

Dr. Ala SAINENCO

Memorialul Ipoteşti - Centrul Naţional de Studii „Mihai Eminescu”, Botoşani, România

Dr. Felix NICOLAU Universitatea din Lund, Suedia

Dr. hab. Maria ȘLEAHTIȚCHI Institutul de Filologie Română „B. P.-Hasdeu”, Chișinău, Republica Moldova

Dr. Paul CERNAT

Institutul de Istorie şi Teorie Literară „G. Călinescu”, București; Universitatea din București, România

Dr. Doina BUTIURCĂ Universitatea „Petru Maior”, Târgu-Mureș, România

Dr. hab. Nina CORCINSCHI Institutul de Filologie Română „B. P.-Hasdeu”, Chişinău, Republica Moldova

Dr. hab. Eugenia MINCU Institutul de Filologie Română „B. P. -Hasdeu”, Chișinău, Republica Moldova

Dr. hab. Alexandru BURLACU Institutul de Filologie Română „B. P.-Hasdeu”, Chișinău, Republica Moldova

Dr. hab. Andrei ȚURCANU Institutul de Filologie Română „B. P.-Hasdeu”, Chișinău, Republica Moldova

REDACTOR: Ecaterina PLEȘCA 
SUMAR

\section{DIN OPERA SAVANTULUI EUGENIU COȘERIU: \\ 100 DE ANI DE LA NAȘTERE}

Eugeniu COȘERIU, Structurile lexematice . . . . . . . . . . . . . . . 7

\section{CRITICĂ ȘI ISTORIE LITERARĂ}

Nina CORCINSCHI, Erosul - de la heros la performance . . . . . . . . . 22

Alexandru BURLACU, Pan Halippa, un poet cu „Flori de pârloagă” . . . . . 31

Galina ANIȚOI, Paradoxurile tranziției. Personajele lui Dan Lungu,

Iulian Ciocan și Dumitru Crudu între nostalgie și schimbare . . . . . . . . . 45

Oxana GHERMAN, Povestea „Ivan Turbincă” de Ion Creangă

și noul experiment hipertextual . . . . . . . . . . . . . . . . . . . . . 54

Dumitru APETRI, Receptarea prozei din Republica Moldova

în Ucraina în a doua jumătate a secolului al XX-lea . . . . . . . . . . . . 61

\section{GRAMATICĂ}

Elena CONSTANTINOVICI, Structuri fundamentale cu pronume reflexiv la cazul dativ în limba română . . . . . . . . . . . . . 69

Petru BUTUC, Aspecte definitorii ale subiectului logic în propoziție 76

\section{ISTORIE A LIMBII}

Galaction VEREBCEANU, Studiu lingvistic asupra manuscrisului „Sandipa". Morfologia (3.2.). Pronumele . . . . . . . . . . . . . . . . . 84

\section{LEXICOLOGIE ȘI TERMINOLOGIE}

Liliana BOTNARI, Indici lexicali variaţionali în „Amintiri din copilărie” de Ion Creangă . . . . . . . . . . . . . . . . . . . . . . . . . . . 94 
Livia CARUNTU-CARAMAN, Englezisme recente - din uz

în dicționar . . . . . . . . . . . . . . . . . . . . . . . . . . . . 103

Eugenia MINCU, Repere mitologice ale dubletelor greco-latine

şi terminologia . . . . . . . . . . . . . . . . . . . . . . . . 111

\section{FOLCLORISTICĂ}

Tatiana BUTNARU, Balada „Meşterul Manole”: o interpretare arhetipală . . 119

\section{RECENZII}

Eugeniu Coșeriu: vocația universalității. Chișinău: Știința, 2021, 484 p.

(Galaction VEREBCEANU) .

Maria Onofraş, Tamara Pahomi, Valeriu Sclifos, Lidia Vrabie, Ana Vulpe.

Dicţionar explicativ tematic. Universul. Natura. Omul. Chişinău: Tipogr.

„Reclama”, 2020, 460 p. (Liliana POPOVSCHI) . . . . . . . . . . . . . . 132

\section{ANIVERSĂRI}

Nina CORCINSCHI, Gheorghe POPA, Un vis cât o viață sau o viaţă de vis . . . . . . . . . . . . . . . . . . . . . . . . . . . 135 


\section{SUMMARY}

\section{FROM THE WORK OF THE SCIENTIST EUGENIU COȘERIU: 100 YEARS FROM BIRTH}

Eugeniu COȘERIU, Lexical Solidarities . . . . . . . . . . . . . . . . . 7

\section{LITERARY CRITICISM AND HISTORY}

Nina CORCINSCHI, Eros - from heros to performance . . . . . . . . , . . 22

Alexandru BURLACU, Pan Halippa, a Poet with „Flori de pârloagă” . . . . 31

Galina ANIT,OI, Paradoxes of Transition. Dan Lungu, Iulian Ciocan and Dumitru Crudu's Characters between Nostalgia and Change . . . . . . . 45

Oxana GHERMAN, The story „Ivan Turbincă” by Ion Creangă and the New Hypertextual Experiment . . . . . . . . . . . . . . . . . . 54

Dumitru APETRI, The Reception of Prose from the Republic of Moldova in Ukraine in the Second Half of the 20th Century . . . . . . . . 61

\section{GRAMMAR}

Elena CONSTANTINOVICI, Fundamental Structures with Reflexive Pronoun in Dative in Romanian . . . . . . . . . . . . . . . . 69 Petru BUTUC, Defining Aspects of the Logical Subject in the Sentence . . . . 76

\section{HISTORY OF LANGUAGE}

Galaction VEREBCEANU, Linguistic Study on the „Sandipa” Manuscript. Morphology (3.2.). Pronouns . . . . . . . . . . . . . . . . . 84

\section{LEXICOLOGY AND TERMINOLOGY}

Liliana BOTNARI, Lexical Indices of Variation in „Amintiri din Copilărie” by Ion Creangă . . . . . . . . . . . . . . . . . . . . . . . . . . . 94 
Livia CARUNTU-CARAMAN, Recent Anglicisms - from use

in the Dictionary . . . . . . . . . . . . . . . . . . . . . . . . . . 103

Eugenia MINCU, Mythological References of Greek

and Latin Doublets and Terminology . . . . . . . . . . . . . . . . . . 111

\section{FOLKLORISTICS}

Tatiana BUTNARU, The Ballad „Meşterul Manole”:

an Archetypal Interpretation

\section{REVIEWS}

Eugeniu Coșeriu: vocația universalităţii. Chișinău: Știința, 2021, 484 p.

(Galaction VEREBCEANU) . . . . . . . . . . . . . . . . . . . . . 127

Maria Onofraş, Tamara Pahomi, Valeriu Sclifos, Lidia Vrabie, Ana Vulpe.

Dicţionar explicativ tematic. Universul. Natura. Omul. Chişinău: Tipogr.

„Reclama”, 2020, 460 p. (Liliana POPOVSCHI) . . . . . . . . . . . . . . 132

\section{ANNIVERSARIES}

Nina CORCINSCHI, Gheorghe POPA, A Dream as a Life or a Dream Life . . . . . . . . . . . . . . . . . . . . . . . . . . 135 


\title{
Eugeniu COŞERIU
}

\section{STRUCTURILE LEXEMATICE*}

\section{Lexical Structures}

\begin{abstract}
In the present study Eugeniu Coşeriu talks about the lexical structures that can be identified in the vocabulary of a language. As the author shows, they can be either paradigmatic or syntagmatic. Paradigmatic structures, in turn, can be primary (lexical fields and lexical classes) or secondary (structures of modification, development, composition), and syntagmatic structures or solidarity can be of three types, conventionally called: affinity, selection and implication.

Keywords: vocabulary, semantics, signifier, meaning, lexical point of view, semasiological point of view, lexical structures.

\section{Rezumat}

În studiul de faţă Eugeniu Coşeriu vorbeşte despre structurile lexematice ce se pot identifica în vocabularul unei limbi. După cum arată autorul, acestea pot fi fie paradigmatice, fie sintagmatice. Structurile paradigmatice, la rândul lor, pot fi primare (câmpuri lexicale şi clase lexicale) sau secundare (structuri de modificare, de dezvoltare, de compunere), iar structurile sintagmatice sau solidarităţile pot fi de trei tipuri, numite convenţional: afinitate, selecţie şi implicaţie.

Cuvinte-cheie: vocabular, semantică, semnificant, semnificat, punct de vedere lexematic, punct de vedere semasiologic, structuri lexematice.

0.1. Ne limităm aici la expunerea tipurilor de structuri lexematice ce se pot identifica în vocabularul unei limbi. Preliminariile teoretice şi metodologice, la fel ca şi distincţiile prealabile necesare pentru identificarea acestor structuri, le-am expus în alte părţi, în special, în raportul nostru Structura lexicală şi însuşirea vocabularului, publicat în „Actes du premier colloque international de linguistique appliquée", Nancy, 1966 (= Annales de

* Nota redacției: Traducerea este semnată de Silviu BEREJAN și publicată în RLȘL, 1992, nr. 6, p. 41-58. Datele originalului: Les structures lexématiques par Eugenio Coseriu. În: Zeitschrift für französische Sprache und Literatur. Beiheft. Neue Folge. Heft 1, 1968. Wiesbaden, S. 3-16.
\end{abstract}


l'Est, Mémoire nr. 31), p. 175-217. Va fi suficient de a aminti aici că e vorba de structura conţinutului (,,semnificatul”) lexical.

0.2. Aceasta implică chiar de la început o distincţie între raporturile de semnificare (significare) şi raporturile de desemnare (designare). Raporturile de semnificare (significare) sunt raporturi între semnificaţi, în timp ce raporturile de desemnare (designare) sunt raporturi între semne în întregimea lor şi realităţile extralingvistice desemnate:

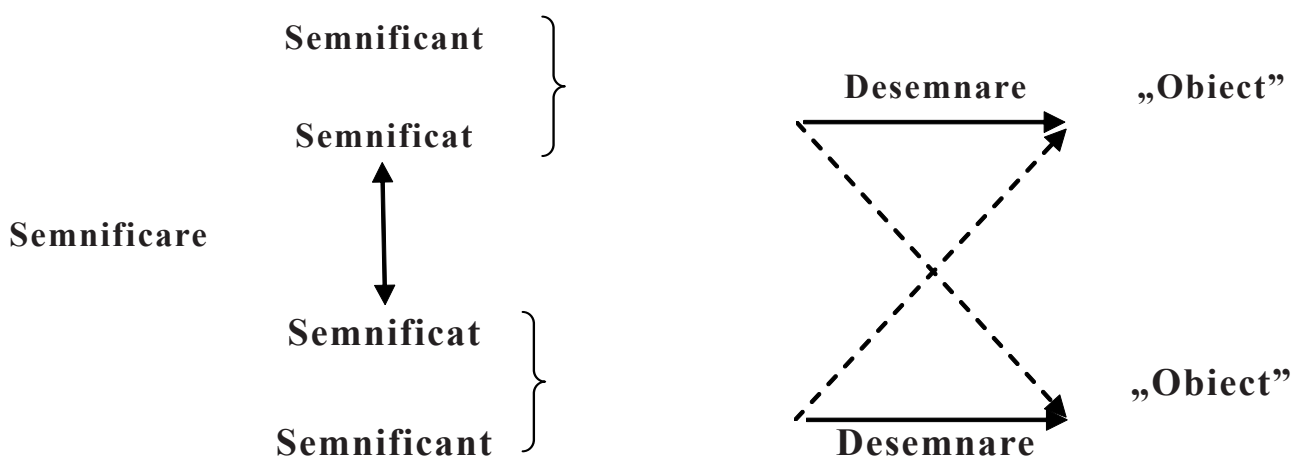

Astfel, desemnarea (designarea) a două semne poate fi identică fără ca semnificaţii lor să fie la fel. De exemplu, clasele desemnate prin cuvintele greceşti brotós şi ánthrōpos sunt identice (este vorba în ambele cazuri de clasa «Fiinţe umane»), în timp ce semnificaţii respectivi nu sunt identici, deoarece brotós înseamnă 'om ca non-dumnezeu', pe când ánlhrōpos înseamnă 'om ca non-animal'. În lexematică este vorba exclusiv despre structurarea raporturilor de semnificare (significare).

1.1. Acest punct de vedere separă lexematica de alte discipline lexicologice, care, de asemenea, au fost numite „structurale” şi care, de asemenea, se referă la „semantică”, în sensul larg al acestui termen.

1.2.1. Întâi şi întâi, punctul de vedere lexematic nu trebuie să fie confundat cu punctul de vedere onomasiologic. În onomasiologie, punctul de pornire este un se mnificat şi se studiază raporturile dintre acest semnificat şi diferiţii s e mnificanţi care îl exprimă. După părerea noastră, dacă se exclud parafrazele, definiţiile şi cazul particular al semnificaţilor arhilexematici, aceste raporturi sunt totdeauna de natură ,interlingvistică”: este vorba despre semnificanţi aparţinând la diferite limbi. Aceste limbi diferite pot fi limbi istorice (de exemplu: franceza, italiana, spaniola etc.) sau limbi funcţionale în interiorul aceleiaşi limbi istorice (dialecte, niveluri, stiluri de limbă). Astfel, exemplul invocat de dl Heger, pentru a justifica onomasiologia (soixante-dix opus lui septante), se referă la limbi diferite din interiorul francezei. Semnificatul conotativ al lui septante ('belgian', 'elveţian') revelează cu precizie acest fapt şi nu aparţine semnificatului lexical (denotativ $-n$. tr.), în sens lexematic: acesta e un semnificat care caracterizează sisteme lingvistice întregi. 
1.2.2. Pe de altă parte, punctul de vedere lexematic trebuie să fie separat de punctul de vedere semasiologic. În semasiologie, punctul de pornire este un s e $\mathrm{m} n$ i f i c a n t şi se studiază raporturile care unesc acest semnificant cu diferiţii s e m n i f i c a ţ i pe care el îi poate exprima. Aceste raporturi sunt „intralingvistice” în cazul omofoniei (de exemplu: fr. [so], 'sot', 'seau', 'sceau' etc.); în afara acestui caz, ele sunt raporturi interlingvistice, referindu-se în aceeaşi măsură la diferite limbi istorice sau la diferite limbi funcţionale în interiorul aceleiaşi limbi istorice.

1.2.3. Aceste două puncte de vedere sunt absolut-legitime, dar ele sunt diferite de punctul de vedere al lexematicii, care se referă doar la semnificaţii lexicali ai unei singure şi aceleiaşi limbi funcţionale (sistem lingvistic). În plus, aceste două puncte de vedere depind, după părerea noastră, de lexematică, deoarece ele implică identificarea unuia sau a câtorva semnificaţi lexicali. Astfel, în cazul onomasiologiei verbelor franceze se rappeler se souvenir 'a-şi aminti', recent studiate de dl Baldinger, operaţia lexematică preliminară, de care depinde tot restul, este constatarea opoziţiei dintre 'se souvenir' şi 'se rappeler', or, tratamentul onomasiologic este posibil, pentru că punctul de plecare este un semnificat arhilexematic ('se rappeler'). Într-adevăr, un semnificat arhilexematic, în mod firesc, poate fi exprimat de toţi semnificanţii lexematici ai câmpului lexical respectiv. Astfel, semnificatul 'siège' poate fi exprimat de diferiţi semnificanţi lexematici ai câmpului «Siège», studiat de dl B. Pottier (tabouret 'taburet', chaise 'scaun', fauteuil 'fotoliu', canapé 'canapea' etc.).

1.3. O formă particulară a punctului de vedere semasiologic este aşazisa „semantică structurală” a lui Katz şi Fodor. În realitate, în această semantică este vorba nu despre structura semnificatului, ci despre structura interpretării, prezentată sub forma unor dependențe, la fel cum se prezintă structura sintactică. Astfel, pornind de la:

The man hit the ball 'Omul loveşte mingea'

se ajunge în analiza sintactică până la elementele morfematice (semnificanţi) combinate în această frază (de exemplu, până la ball), după care se pune problema de a alege între semnificaţii lexicali posibili ai acestor semnificanţi (în cazul lui ball: 'bal', 'minge', 'proiectil'). Vasăzică, analiza sintactică stabileşte elementele morfematice combinate cu adevărat, în timp ce aşazisa ,analiză semantică” îşi propune să identifice semnificaţii lexicali prezenţi, eliminând alţi semnificaţi lexicali posibili ai aceloraşi semnificanţi. Punctul de pornire al acestei „semantici” este, prin urmare, un s e m n ificant lexical şi problema care se pune este cea a interpretării sale, adică cea a identificării semnificatului său. Or, întrucât semnul este constituit dintr-un semnificant şi un semnificat, „structurarea”, propusă de această „semantică”, se reduce la identificarea semnelor (dezambiguare): prin urmare, se stabileşte că e vorba despre semnul «ball - 'minge'», şi nu despre semnul «ball - 'bal'». Adevărul este că această semantică nu face deosebire între identificarea semnului şi analiza semnificatului, deoarece ea întrebuinţează anume elemente ale semnificatului pentru identificare; dar ea 
nu este o metodă de analiză a semnificatului, cum se pretinde a fi, pentru că rămâne în afara raporturilor de semnificare (significare) şi nu stabileşte paradigme de conţinut.

În rest, problema d e z a m b i g u ă r i i nu este limitată la lexicologie. De asemenea, se poate „dezambigua” în gramatică. Să luăm, de exemplu, unitatea (grafematică) latină exercitus 'armată': ea poate fi atât 'singular', cât şi 'plural'; dacă este 'singular', ea poate fi atât 'genitiv', cât şi 'nongenitiv', şi dacă este 'non-genitiv', ea poate fi atât 'nominativ', cât şi 'vocativ'; dacă, din contra, este un plural, ea poate fi atât 'acuzativ', cât şi 'non-acuzativ', şi dacă este 'non-acuzativ', ea poate fi din nou atât 'nominativ', cât şi 'vocativ':

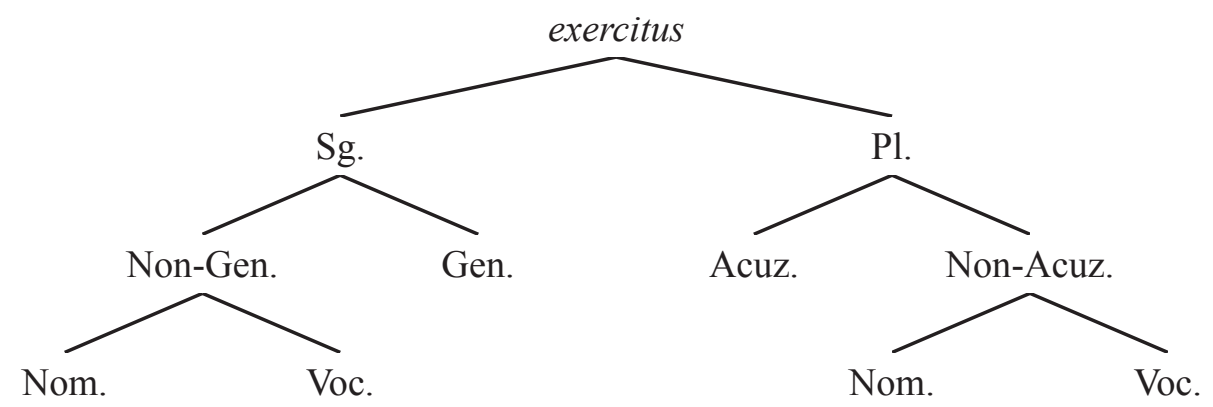

De asemenea, se pot „dezambigua” numele proprii, unde, evident, nu avem de-a face cu semnificaţi lexicali opozitivi (cf. mai jos exemplul Santiago).

Pe de altă parte, nefiind decât structură de interpretare, această „structură” nu corespunde raporturilor de semnificare (significare). Astfel, când semnificanţii nu coincid, valoarea 'nominativ singular' este diferită de cea de 'genitiv singular', de exemplu, în cazul lui amicus amici 'prieten', unde, urmând schema „structurală” a interpretării, aceasta nu se aplică decât semnificantului ambiguu amici, dar nu şi lui amicus, semnificant imediat interpretabil:

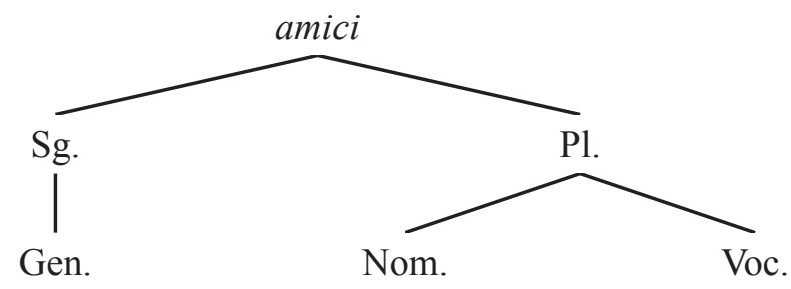

Într-adevăr, acest tip de ,structură” este întotdeauna diferit, după omofoniile semnificanţilor şi după omofonele pe care le examinăm. De exemplu, pentru un semnificant, cum ar fi Santiago, se poate pune chiar de la început problema: 'persoană' sau 'nume de loc'? Mai apoi, pentru 'nume de loc' s-ar putea pune alternativa: 'munte' sau 'non-munte': 'insulă' sau 'non-insulă'; pentru 'non-insulă': 'provincie' sau 'oraş'; pentru' 'oraş': 'în Europa sau 'în America'; pentru 'în Europa': 'în Spania' sau 'în Portugalia'; pentru 'în Portugalia': Santiago do Escoural' sau 'Santiago do Cacém' şi aşa mai departe. Or, am putea să ne întrebăm 
ce au toate acestea cu structura semnificatului ca atare, dacă cu adevărat cineva nu cunoaşte semnificatul lui Santiago de Chili, de exemplu, dacă el nu ştie că există o serie de Santiago în alte părţi.

Această „semantică” nu este eronată, dar ea este absolut inutilă în ceea ce priveşte descrierea structurilor şi opoziţiilor semantice (În realitate, ea presupune aceste structuri ca deja cunoscute şi le întrebuinţează la identificare). Ea nu este decât un aranjament de semnificaţi şi de accepţiuni ce corespund unui semnificant, adică un aspect al practicii lexicografice. Şi chiar ca practică lexicografică, ea nu are posibilitate să facă distincţie între lexeme (unităţi semantice lexicale), accepțiuni (variante semantice lexicale) şi metafore. În sfârșit, întrucât pornește de la semnificant, ea nu mai poate coincide cu definiţia lexicografică adevărată şi curată. Într-adevăr, definiţia trebuie să indice „genul” şi „diferenţa specifică”, adică lexemul imediat superior ce o conţine (arhilexemu1) şi trăsăturile distinctive ale lexemului examinat prin opoziţie cu acest arhilexem şi cu alte lexeme ce se conţin în acelaşi arhilexem (dacă el există), pe când „dezambiguarea” nu face decât să identifice un semn fără a specifica semnificatul său opozitiv. Sunt lingvişti care consideră semantica lui Katz şi Fodor drept o revoluţie în semantică. In realitate, ea nu este revoluţionară decât în raport cu bloomfieldismul şi, de fapt, ea nu este o revoluţie în semantică, pentru că nu se referă la structura planului semnificatului.

1.4. În fine, se cuvine să deosebim structurile lexematice de câmpurile a s oc i a ti ve (tratate, de ex., de Bally, Matoré, Guiraud). Acestea nu sunt structuri în adevăratul înţeles al termenului, ci „configuraţii”: ele nu se referă la structurarea semnificatului prin intermediul trăsăturilor distinctive (opoziţiile semantice), ci la asocierile unui semn cu alte semne, asocieri stabilite prin similitudine sau prin contiguitate, atât de semnificanţi, cât şi de semnificaţi. În parte, de altfel, ele ţin de asocierile privind lucrurile şi nu unităţile lingvistice ca atare.

1.5. Evident, tot ce tinde să fie separat de lexematică se referă, de asemenea, la funcţionarea limbajului şi trebuie să fie studiat. Nu este vorba pentru noi decât de a distinge ceea ce ţine şi ceea ce nu ţine de structura s e mantică în măsura în care ea este s t r u c t u ră a se m n ifi c a t u lui . Toată problema, într-un anume sens, este,,semantică”, dacă ea ţine de semnificare (significare). Însă o problemă ,semantica” nu este 1 e x e m a ti c ă, dacă ea nu se referă la raporturile structurale paradigmatice şi sintagmatice ale semnificaţilor lexicali în unul şi acelaşi sistem lingvistic.

2. Structurile lexematice ce se pot identifica în vocabularul unei limbi sunt fie paradigmatice, fie sintagmatice. Structurile paradigmatice, la rândul lor, pot fi pri ma r e (câmpuri lexi ca le şi clase lexicale) sau secundare (structuri de modificare, de dezvoltare şi de compunere). Structurile sintagmatice sau s o li d a rit ăţi le potfidetreitipurice vorfi numite convenţional: a fi n it a te, selecţie şi implicaţie**. Tabloul general al structurilor lexematice pe care propunem să le distingem este, în consecinţă, următorul:

** Despre solidarităţile lexicale şi tipurile lor în viziunea prof. Eugeniu Coşeriu se poate citi mai amănunţit în studiul său Solidarităţile lexicale, publicat pentru prima dată în româneşte în RLŞL, 1992, nr. 5, p. 37-45; precum şi în Philologia, 2021, nr. 1, p. 7-17. 
$\underline{\text { Structuri paradigmatice }}$

(opozitive)

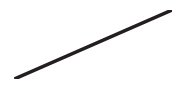

Primare

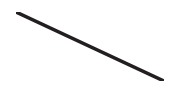

$\underline{\text { Secundare }}$ $\underline{\text { Structuri sintagmatice }}$

(combinatorii)
Afinitatea

Selecția

Implicația
Câmpul lexical

Clasa lexicală
Modificarea

Dezvoltarea

Compunerea

3.0.1. Structurile paradigmatice sunt, în lexic, de aceea şi natură ca şi structurile paradigmatice din restul unui sistem lingvistic. Ele sunt structuri constituite de unităţi lexicale ce se află în opoziţie pe axa selecţiei. Astfel: 'bun' - 'rău', 'casă' - 'căsuţă', 'a muri' - 'mortal' sunt opoziţii ce manifestă structuri paradigmatice. O structură paradigmatică este primară, dacă termenii săi se implică reciproc fără ca unul să fie primar în raport cu celelalte (astfel, de exemplu, 'tânăr' implică pe 'bătrân' şi 'bătrân' implică pe 'tânăr', dar nici unul dintre aceşti doi termeni nu este primar în raport cu celălalt). O structură paradigmatică este secundară, dacă implicaţia între termenii săi este în ,sens unic”, de ex., în cazul unei structuri cu doi termeni, dacă unul dintre aceşti termeni îl implică pe celălalt, dar nu invers. Astfel, 'casă' - 'căsuţă', 'a muri' - 'mortal', 'a lucra' - 'lucrător' sunt structuri secundare, pentru că primul termen din fiecare cuplu este implicat de cel de al doilea, dar nu invers (de exemplu, definiţia conţinutului 'casă' este independentă de conţinutul 'căsuţă', în timp ce definiţia conţinutului 'căsuţă’ înglobează în mod necesar conţinutul 'casă').

3.0.2. Există două tipuri de structuri paradigmatice primare: câmpul lexical şiclasa lexicală .

3.1.1. Un câmp 1 ex i c a 1 este o structură paradigmatică constituită din unităţi lexicale ce îşi împart o zonă de semnificare (significare) comună şi se află în opoziţie imediată unele cu altele. Criteriile pentru delimitarea câmpurilor lexicale au fost stabilite explicit de dl Lyons. Este vorba întotdeauna despre unităţi lexicale între care se poate face alegere într-un punct dat al lanţului vorbit. Astfel, de exemplu, dacă avem contextul: am fost la Mayence timp de..., alegerea ce se poate opera este limitată la paradigma: secundă, minut, oră, zi, săptămână, lună, an etc., în timp ce termeni ca arbore, elev, caiet etc. sunt excluşi din alegere. Prezentând lucrurile în alt 
mod, se poate spune că un câmp lexical este constituit de termenul prezent într-un punct dat al lanţului vorbit şi termenii pe care prezenţa sa îi exclude. De exemplu, prezenţa lui roşu în expresia acest lucru e roşu exclude pe $a l b$, verde, galben etc. (termeni aparținând aceluiaşi câmp), dar nu pe mare, mic, lung, scurt etc., ce aparţin altor câmpuri. Astfel, lat. senex 'bătrân' vetulus - vetus 'vechi'/ iuvenis 'tânăr' - novellus - novus 'nou' sau chiar sp. viejo 'bătrân joven 'vechi' - nuevo 'nou' sunt câmpuri lexicale (în care nu se iau în consideraţie decât termenii fundamentali).

3.1.2. Câmpurile lexicale sunt analogice sistemelor de consoane sau de vocale din fonologie, fiind ca şi acestea analizabile în trăsături distinctive. O unitate de conţinut lexical exprimată în sistemul lingvistic (de exemplu, conţinutul 'senex' în latină) este un 1 e x e m. Un lexem al cărui conţinut este identic în întregime cu conţinutul unui câmp lexical este un a rh i 1 e x e m. Trăsăturile distinctive ce constituie lexemele pot fi numite s e m e (termen folosit, de ex., de dl Pottier).

În esenţă, această concepţie a câmpului lexical, pe care am propus-o încă în 1962, coincide cu concepţia structurii lexicale elaborată aproape în acelaşi timp şi într-un mod independent de dnii Pottier şi Greimas (şi, în parte, de asemenea, cu cea a dlui Lyons). Cu toate acestea, în practică, noi ne deosebim atât de dl Pottier, care propune să fie analizate câmpuri întregi pornind de la domenii obiective ale realităţii extralingvistice, cât şi de dl Greimas, care îşi propune să ajungă chiar de la început la elementele distinctive minimale ale lexemelor. Noi propunem, din contra, să pornim de la opoziţiile imediate, de exemplu, între două sau trei lexeme, să identificăm trăsăturile distinctive care contrapun aceşti termeni şi să construim câmpul lexical într-un mod treptat, stabilind noi opoziţii între termenii deja examinaţi şi alţi termeni. La fiecare etapă a analizei vom avea, pe de o parte, trăsături distinctive minimale identificate de acum şi, pe de alta, o valoare comună a termenilor depistaţi, valoare care va putea, la rândul ei, să fie analizată în trăsături distinctive minimale şi într-o valoare comună mai redusă, prin opoziţia lor cu alţi termeni. Astfel, de exemplu, se poate porni de la grupul german:

$$
\begin{aligned}
& \text { 'sitzen' ('a şedea') - 'liegen' ('a sta culcat') - } \\
& \text { 'stehen' ('a sta în picioare') }
\end{aligned}
$$

în care valoarea comună este 'poziţie în raport cu o suprafaţă', iar trăsăturile distinctive care caracterizează fiecare dintre aceşti termeni corespund, de fiecare dată, unei poziţii diferite (ce poate fi reprezentată, de exemplu, prin: I_, , I). Apoi, acest grup se poate opune grupului: 'setzen' ('a aşeza') - 'legen' ('a pune culcat, orizontal') - 'stellen' ('a pune în picioare, vertical') prin 


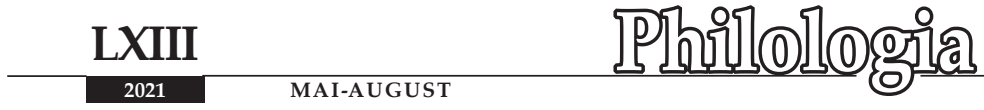

trăsăturile distinctive: 'staticitate'/ 'dinamicitate'. La o a treia etapă, cei şase termeni în discuţie se vor putea opune termenului 'stecken' ('a băga, a vârî'), prin mijlocirea trăsăturilor 'poziţie vizibilă'/ 'poziţie invizibilă'. După care, cei şapte termeni examinaţi de acum se vor putea opune termenului 'sein' ('a fi') prin intermediul trăsăturilor 'poziţie'/ 'non-poziţie'. Iar mai apoi, după ce am stabilit opoziţiile dintre adjectivele ce se referă la vârsta fiinţelor sau lucrurilor ('tânăr', 'nou', 'vechi' etc.), toate aceste adjective împreună se vor putea opune adjectivelor de felul lui 'mic', 'mare' etc., identificând, în ceea ce la prima etapă era pur şi simplu valoare comună a lexemelor examinate, noi trăsături distinctive cum ar fi 'dimensiune în timp'/ 'dimensiune în spaţiu'. În realitate, acest procedeu este analog procedeului din fonologie, unde avem, de exemplu, opoziţii între foneme ca $p-b-m$ şi, respectiv, între $t-d-n$ şi contrapunem apoi cele două valori comune ale fiecăruia dintre cele două grupuri: „bilabialitate”/ „dentalitate”.

3.1.3. Analogia cu fonologia poate fi urmărită şi în alte privinţe, dar analogia nu înseamnă identitate. Într-adevăr, trebuie observat că există diferenţe însemnate între câmpurile lexicale şi sistemele de vocale sau de consoane:

a) În câmpurile lexicale putem avea arhilexeme efectiv realizate la mai multe nivele. Acest fapt nu este necunoscut în fonologie, dar în lexematică nivelele capabile de a fi exprimate prin arhiunităţi pot fi mult mai numeroase. Astfel, lexemul românesc 'bou' aparţine arhilexemului 'vita', acesta din urmă, la rândul său, aparţine unui arhilexem de nivel superior 'dobitoc' inclus apoi în arhilexemul 'făptură', care, în fine, este inclus într-un arhilexem 'fiinţă'. Acesta e ca şi când am avea într-un sistem fonologic arhifoneme corespunzând, de exemplu, tuturor vocalelor sau tuturor consoanelor.

b) În cazul fonologiei, substanţa fonică posibilă nu este în întregime organizată de unităţile fonologice ale unei limbi. Domenii mai mult sau mai puţin largi ale acestei substanţe rămân în afara structurării fonice a unei limbi date. Astfel, de exemplu, substanţa $\hat{u}$ nu aparţine nici unui fonem italian: din punctul de vedere al limbii italiene, ea este pur şi simplu substanţă fonică neorganizată lingvistic. Altfel se prezintă lucrurile în ce priveşte substanţa semantică lexicală care, chiar dacă nu este structurată prin unităţi lexematice, poate fi structurată prin perifraze ocazionale sau tradiţionale (cf. românescul cu scaun la cap pentru fr. raisonnable sau cu dare de mână, cu tragere de inimă pentru it. facoltoso, volenteroso).

c) În lexic se constată adesea interferenţe între diferite câmpuri, cu arhilexeme ce există pentru fiecare câmp. Ceea ce demonstrează interferenţele constatabile în câmpul lexical românesc «Făptură»: 


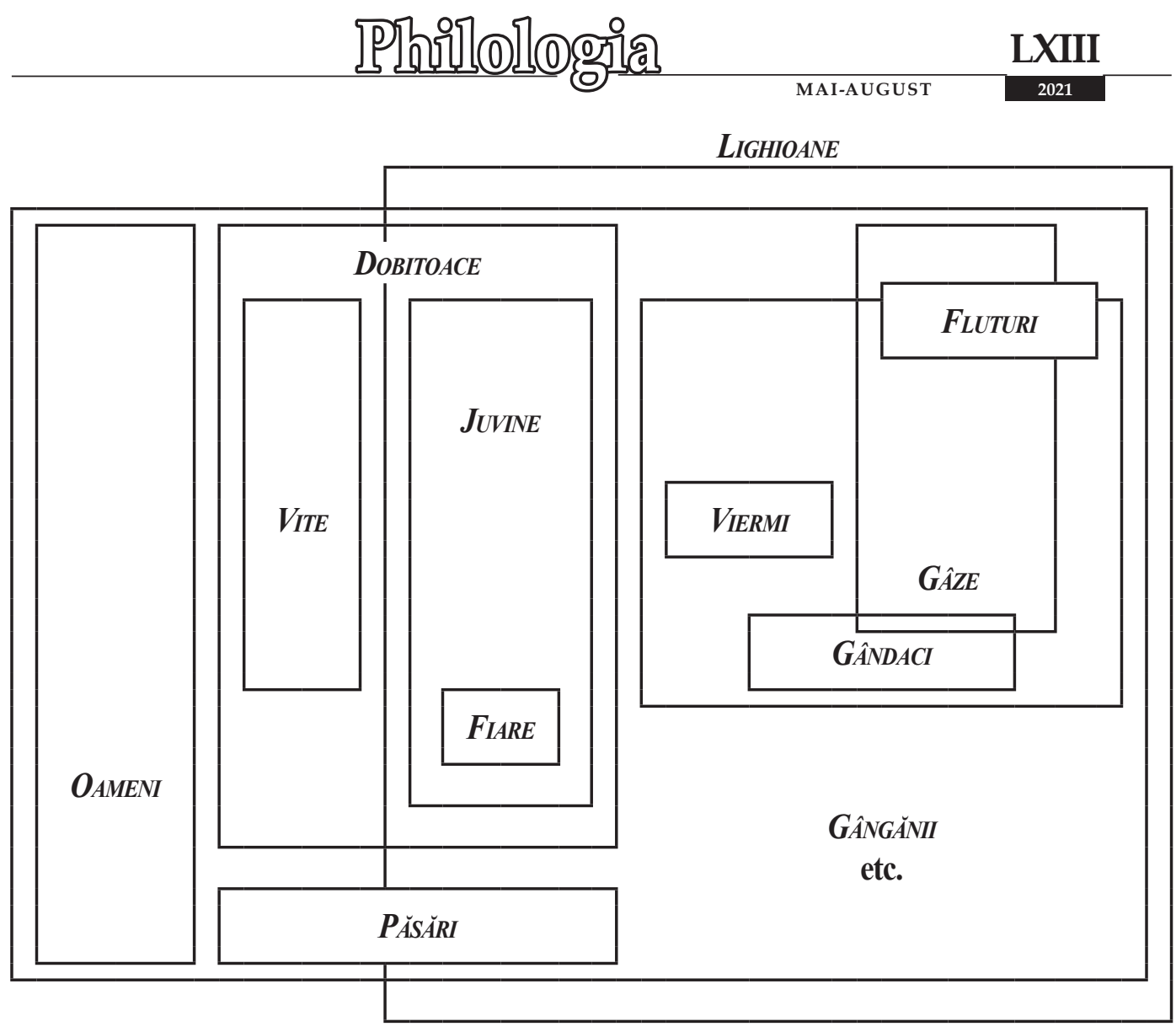

E ca şi când am avea într-un sistem fonologic arhifoneme, de exemplu, pe de o parte, pentru toate fonemele surde, pe de alta, pentru toate fonemele oclusive, pentru toate fonemele dentale etc. Acest lucru depinde de faptul că lexicul unei limbi nu constituie la etape succesive o clasificare de tipul taxonomiilor elaborate de ştiinţe, ci, în realitate, reprezintă o serie de clasificări simultane şi diferite, încât acelaşi termen poate corespunde mai multor arhilexeme în acelaşi timp.

d) Un lexem poate funcţiona în mai multe câmpuri în acelaşi timp fără a exista diferenţă de nivel între aceste câmpuri. Astfel, fr. frais 'proaspăt' funcţionează în câmpul adjectivelor de felul lui neuf, nouveau 'nou', vieux 'vechi' etc. cât şi în câmpul adjectivelor ce se referă la temperatură (froid 'rece', chaud 'cald' etc.). Acest fapt este analog funcţionării aceluiaşi fonem atât în sistemul vocalelor, cât şi în sistemul consoanelor aceleiaşi limbi. Dar el pare a fi mai frecvent în lexic decât în domeniul fonologiei.

e) În lexic se pot constata neutralizări şi sincretisme între diferite câmpuri. Astfel, de exemplu, fr. petit, germ. klein 'mic' pot fi aplicate copiilor (les petits, die Kleinen 'cei mici', prin opoziţie cu les grands, die Grossen 'cei mari'), ceea ce implică o neutralizare între câmpul dimensiunii spaţiale şi cel al dimensiunii vitale. Într-un mod analog, fr. enfants, germ. Kinder 'copii' funcţionează în acelaşi timp în câmpul dimensiunii vitale şi, 


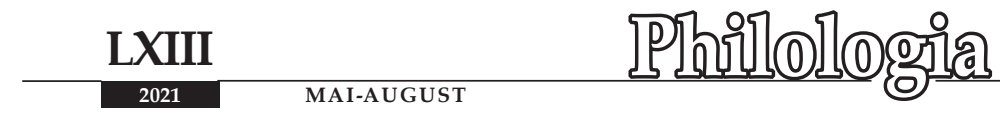

totodată, ca termeni neutri respectivi pentru fils et filles, Söhne und Töchter 'fii şi fiice', ceea ce reprezintă, în consecinţă, un sincretism între aceste două câmpuri.

3.2. O c la s ă 1 e x i c a $1 \breve{a}$ este o clasă de lexeme determinate de un c 1 a s e m, acesta fiind o trăsătură distinctivă ce funcţionează într-o întreagă categorie verbală (sau, cel puţin, într-o întreagă clasă deja determinată de un alt clasem), într-un mod, în principiu, independent de câmpurile lexicale. Clasele se relevă în îmbinările gramaticale sau lexicale de lexeme: aparţin aceleiaşi clase lexemele care permit aceleaşi îmbinări lexicale sau gramaticale, sau lexicale şi gramaticale în acelaşi timp. Astfel, de exemplu, lat. 'miles' ('soldat'), 'rex' ('rege'), 'magister' ('magistru') etc. se îmbină cu 'senex' ('bătrân'), în timp ce 'quercus' ('stejar'), 'canis' ('câine'), 'aquila' ('vultur') etc. se îmbină, pentru un semnificat analog, cu 'vetulus' ('vechi'); din cauza aceasta miles, rex, magister etc. aparţin aceleiaşi clase, diferite de clasa căreia îi aparţin quercus, canis, aquila etc. Spre exemplu, pentru substantive se pot, stabili clase, cum ar fi «Fiinţe vii», «Lucruri», iar în interiorul clasei «Fiinţe vii», de exemplu, clase ca «Fiinţe umane», «Fiinţe non-umane» etc. Pentru adjective există clase cum ar fi «Pozitiv», «Negativ», care justifică îmbinările copulative de tipul 'bello e buono' ('frumos şi bun'), 'grande e grosso' ('mare şi gras'), 'piccolo e brutto' ('mic şi urât') etc. (adjective ce aparţin de fiecare dată aceleiaşi clase), sau îmbinări adversative de tipul 'povero ma onesto' ('sărac, dar cinstit') (adjective ce aparţin unor clase diferite). Pentru verbe există, de exemplu, clasele bine cunoscute ale tranzitivelor şi intranzitivelor (eventual cu o serie întreagă de subclase). Însă, cu toate acestea, se pot stabili clase verbale diferite. Spre exemplu, pe baza unui clasem al direcţiei în raport cu agentul acţiunii, se poate stabili clasa verbelor «Adlative» (acheter 'a cumpăra', recevoir 'a primi', prendre 'a lua', saisir 'a sesiza' etc.) şi cea a verbelor "Ablative» (vendre 'a vinde', donner 'a da', laisser 'a lăsa', lâcher 'a da drumul' etc.).

În ceea ce priveşte clasele, s-ar putea pune întrebarea dacă ele aparţin lexicului sau gramaticii. În opinia noastră, există clase ce aparţin evident lexicului, deoarece ele implică îmbinări lexicale care le sunt proprii şi care se deosebesc de clasele gramaticale propriu-zise. Astfel, de exemplu, germ. Mensch 'om' este un masculin în gramatică, în timp ce e un termen „,neutru” (aplicându-se atât bărbaţilor, cât şi femeilor) din punct de vedere lexical; Mann 'bărbat' este masculin atât în gramatică, cât şi în lexic, iar Weib 'femeie', Mädchen 'fată' sunt neutre în gramatică, dar feminine în lexic (ceea ce justifică construcţiile de felul das Mädchen mit ihren Brüdern 'fata cu fraţii ei').

Pe de altă parte, trebuie să se facă distincţie între clas e le determinante şi clasele determinate. Clasele determinante sunt clase caracterizate prin claseme, în timp ce clasele determinate sunt clase caracterizate prin trăsături distinctive ca 'ce ţine de clasa X'. Spre exemplu, a se insura - a se mărita, napol. 'nzurarse-maritarse aparţin claselor determinate prin trăsăturile distinctive 'pentru clasa bărbaţilor', 'pentru 
clasa femeilor'; mourir 'a muri' - crever 'a crăpa', bouche 'gură' - gueule 'bot', main 'mână' - patte 'labă', Mund 'gură' - Maul 'bot' etc. aparţin claselor determinate prin trăsăturile distinctive 'pentru fiinţe omeneşti' şi, respectiv, 'pentru animale'. Acest lucru permite clasamente ale lexemelor determinate clasematic după clasele determinate cu care ele se îmbină. Astfel, de exemplu, adjectivele pot fi clasate, în raport cu clasele determinante «Fiinţe vii» - «Lucruri», întâi în adjective sensibile şi în adjective insensibile la aceste clase; iar adjectivele sensibile la aceste clase determinante pot fi clasate în adjective exclusive pentru o clasă (de ex. inteligent, care nu se aplică la lucruri, afară de cazurile când e vorba de activitatea expresivă a fiinţelor vii) şi în adjective diferenţiate după clase (de exemplu, roşcat în raport cu roşu sau blond în raport cu galben).

3.3. Clasele şi câmpurile se pot afla într-unul dintre următoarele trei tipuri de raporturi:

a)

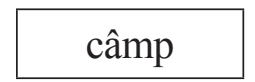

b)

c)

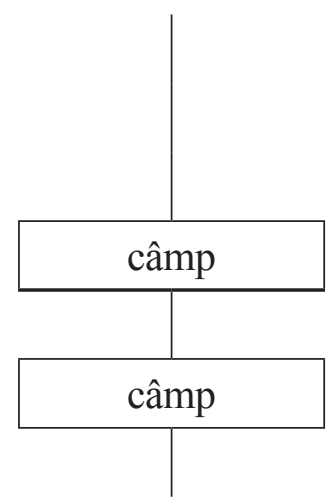

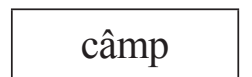

În primul caz, un câmp lexical aparţine în totalitate unei clase. De exemplu, 'om', 'femeie', 'copil', 'băiat', 'fată' etc. constituie un câmp ce aparţine în întregime clasei de «Fiinţe umane». În cazul al doilea, un câmp se află la intersecţia dintre două clase. Astfel, de exemplu, 'a cumpăra' şi 'a vinde' aparţin aceluiaşi câmp, dar sunt separate de clasemele «Adlativ»/ «Ablativ». În cel de-al treilea caz, un lexem se află, de asemenea, la intersecţia a două clase, dar el este insensibil la diferenţa clasematică, întrebuințându-se indiferent într-o clasă sau alta. Este, de exemplu, cazul fr. louer 'a închiria', care poate fi atât adlativ, cât şi ablativ, în timp ce germana face, în cazul dat, o diferenţă clasematică analoagă celei pe care o face franceza pentru acheter 'a cumpăra' şi vendre 'a vinde' (mieten 'a lua în chirie' - vermiten 'a da în chirie'). În cazul unui lexem insensibil la diferenţa de clasă, valoarea clasematică nu se relevă decât în context (cf. rom. a împrumuta cuiva - a împrumuta de la cineva).

4.0.1. Structurile s e c und a r e corespund domeniului tradiţional al formării cuvintelor. Din punct de vedere lexematic, ele se disting prin faptul că implică întotdeauna transformarea ireversibilă a unui termen primar ce există în limbă în calitate de lexem de conţinut şi de expresie. Asta înseamnă 


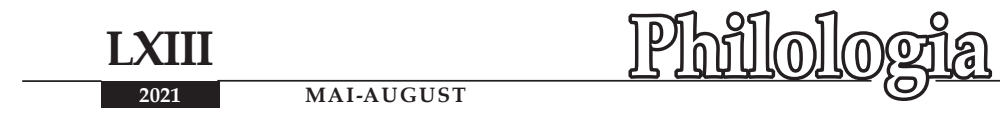

că un termen primar capătă o determinare gramaticală şi cu această determinare gramaticală implicită el este redat din nou lexicului (în sensul că el poate căpăta determinările gramaticale explicite ale termenilor primari). Astfel, de exemplu, căsuţă implică determinarea gramaticală de casă, dar, în acelaşi timp, este un termen ce poate intra în toate categoriile gramaticale proprii termenului casă.

4.0.2. Se disting trei tipuri de structuri secundare, după determinarea gramaticală a termenului primar pe care îl implică şi anume: m o d i fi c a r e a, dezvoltarea şi compunerea.

4.1. Modificare a corespunde unei determinări gramaticale ,inactuale”, adică unei determinări care nu implică o funcţie specifică (în frază) a termenului primar modificat. În general, este vorba despre o cuantificare a termenului primar. Acestei structuri îi corespund, de exemplu, formaţiile diminutive, colectivele, verbele de formaţie prefixală (de exemplu, maison 'casă' - maisonnette 'căsuţă', cavallo 'cal' - cavallino 'căluţ', rufus 'roşiatic' - subrufus 'roşcovan', crier 'a striga' - criailler 'a ţipa' (despre păsări), pleurer 'a plânge' - pleurnicher 'a scânci', rouge 'roşu'-rougeâtre 'roşietic', quercia 'stejar' - querceto 'stejăriş', venir 'a veni' - revenir 'a reveni', voir 'a vedea' - prevoir 'a prevedea').

4.2.1. O d e z v o lt a r e corespunde unei determinări gramaticale ce implică o funcţie specială a termenului primar în frază. Astfel, de exemplu: frumos + functie predicativă $\rightarrow$ frumuseţe ('faptul de a fi frumos'); roșu + funcţie de epitet $\rightarrow$ roşul; en barque 'în barcă' $\rightarrow$ embarquer 'a îmbarca'; de la barque 'din barcă' $\rightarrow$ débarquer 'a debarca'. După cum se vede, o dezvoltare implică întotdeauna schimbarea categoriei verbale a unui termen primar.

4.2.2. Prin urmare, un termen dezvoltat poate constitui punctul de plecare al unei noi dezvoltări. În acest caz, în limbi se pot constata dezvoltări în serie, perfect identificabile în cazurile când este paralelism între expresie şi conţinut. De exemplu: bogat - a se îmbogăţ - imbogăţire, naţiune - naţional - a naţionaliza - naţionalizare.

În calitate de procedeu, existenţa dezvoltării în serie permite să se sară peste etape, adică să se creeze termeni succesivi fără ca termenul implicat anterior să existe efectiv în norma limbii. Astfel, lat. barbatus 'bărbos' implică, din punctul de vedere al sistemului limbii, un verb barbare ('a dota cu o barbă') care, după cum ar părea, n-a fost niciodată format. Vasăzică, dezvoltarea implicată în acest caz a fost: barba 'barbă' $\rightarrow$ (verb) $\rightarrow$ barbatus 'dotat cu barbă'. Tocmai orientarea determinată şi în sens unic a dezvoltării permite constatarea lacunelor din seriile dezvoltate, din punctul de vedere al sistemului lingvistic realizat efectiv.

În afară de aceasta, dezvoltarea implică la fiecare etapă o „deconcentrare” a semnificării (significării). Astfel, de exemplu, it. d'inverno înseamnă 'ce aparţine iernii; de iarnă' (cf. giornata d'inverno 'zi de iarnă'), în timp ce termenul dezvoltat invernale înseamnă atât 'de iarnă', cât şi 'asemănător cu ceea ce aparţine iernii' (cf. giornata invernale 'zi ca de iarnă'). În această privinţă, Charles Bally făcea distincţie între derivarea gramaticală 
(chaleur tropicale $=$ 'căldură de tropice'; héroïne cornelienne = 'eroină de-a lui Corneille') şi derivarea semantică (chaleur tropicale = 'căldură asemănătoare cu cea care este la tropice'; héroïne cornélienne = 'eroină asemănătoare eroinelor lui Corneille'). Or, noi credem că nu e cazul să se facă această distincţie şi că noi avem de-a face în fiecare caz cu o singură valoare a limbii, însă cu o valoare lărgită în raport cu baza dezvoltării.

4.2.3. Dezvoltarea ce porneşte de la baze diferite poate duce la omofonii cu totul diferite de omofoniile cazuale ale termenilor primari. Astfel, de exemplu, în franceză există două serii omofone mortel - mortalité, prima dezvoltată pornind de la conţinutul 'mourir' ('l'homme est mortel' 'la mortalité de l'homme'), a doua - pornind de la conţinutul 'tuer' (le coup a été mortel' - 'la mortalité du coup'). În afară de aceasta, trebuie observat că, deşi dezvoltarea implică întotdeauna o întrebuinţare a termenului primar, putem întâlni dezvoltări diferite după accepţiunea implicată de acest termen (cf., de ex., it. fegato 'ficat' $\rightarrow$ fegatoso 'hepatic'; terra 'pământ' $\rightarrow$ terrestre 'pământesc', terroso 'de (cu) pământ', terreno 'la pământ'; sp. esperar 'a aştepta' $\rightarrow$ espera 'faptul de a aştepta', esperanza 'faptul de a spera').

4.2.4. Se remarcă, în fine, că putem avea combinaţii ale modificării cu dezvoltarea, de exemplu: it. passeggiare 'a se plimba' $\rightarrow$ passeggiata 'plimbare' (dezv.) $\rightarrow$ passegiatina 'loc pentru plimbare' (mod.); germ. gehen 'a merge' - durchgehen 'a trece prin' (mod.) $\rightarrow$ Durchgang 'trecătoare' $($ dezv.); fr. voir 'a vedea' $\rightarrow$ revoir 'a revedea' (mod.) $\rightarrow$ revision 'revizie' (dezv.).

4.3.1. C o m p u n e r e a implică întotdeauna prezenţa a două elemente de bază în raport gramatical. Există două tipuri de compunere şi anume: c ompunerea generic ă (sau ,pronominală”), în care unul din elementele îmbinate este un element generic neidentificabil cu un lexem ce există în limbă, şi c o m p u n e r e a s p e c i f i c ă (sau „nominală”), în care ambele elemente implicate sunt lexeme. Primul tip corespunde unui compartiment a ceea ce se numeşte tradiţional „derivare" (de asemenea, desemnare ce corespunde de multe ori modifi cări i noastre şi d e zvoltări i noastre). Al doilea tip coincide cu ceea ce se numeşte tradiţional „compunere” (exceptând totuşi aşa-zisa compunere verbală pe care noi o clasăm la modificare). Compunere generică avem, de exemplu, în pomme 'măr' (fruct) $\rightarrow$ pommier 'măr' (pom); limón 'lămâie' $\rightarrow$ limonero 'lămâi'; handeln 'a face comerț' $\rightarrow$ Händler 'comerciant'; compunere specifică avem în cazuri precum kaufen + Mann ('om care cumpără') $\rightarrow$ Kaufmann 'cumpărător'.

4.3.2. În rest, cele două tipuri pot să se îmbine; de exemplu: Kindergärtnerin 'lucrătoare la grădiniţa de copii' (comp. specifică [Kindergarten 'grădiniţă de copii'] + comp. generică); Schullehre 'învăţător şcolar' (comp. generică [Lehrer 'învăţător'] + comp. specifică). Tipul francez şi romanic coupe-papier 'cuţit de tăiat hârtie' reprezintă de asemenea o îmbinare a două tipuri, deoarece implică o compunere generică a morfemului expresiei zero (couper 'a tăia' $\rightarrow$ coupe 'taie' - [echivalent al lui 'coupeur' (tăietor), 'ce 


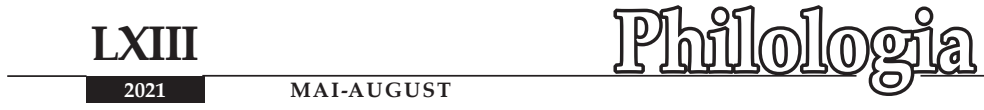

qui coupe' (cel ce taie)]) şi o compunere specifică (compusul generic coupe'cel ce taie' + papier 'hârtie').

5.0. Structurile lexematice sintagmatice sunt solidarităţi între lexeme motivate prin valoarea lor de limbă (linguală). Într-o solidaritate este întotdeauna un termen determinant şi un termen determinat, acesta din urină implicând, în calitate de trăsătură distinctivă, aplicabilitatea la clasa sau la câmpul termenului determinant, sau chiar la membrul determinant dat ca atare. Din acest punct de vedere, se pot distinge trei tipuri de solidarităţi pe care noi le numim: afinitate, selecţie şi implicaţie.

5.1.1. În a f i $\mathrm{n}$ i t a t e este vorba de clasa termenului determinant care funcţionează în calitate de trăsătură distinctivă a termenului determinat (acesta conţine, în consecinţă, o trăsătură distinctivă de tip 'în exclusivitate pentru clasa...'). Este, de exemplu, raportul dintre clasa «Femei» şi lat. nubor 'noră', dintre clasa «Fiinţe omeneşti» şi lat. senex 'bătrân' sau dintre clasa «Animale» şi fr. queule 'bot'.

5.1.2. În s e le cţ i e este vorba de arhilexemul termenului determinant care funcţionează în calitate de trăsătură distinctivă în termenul determinat. Este, de exemplu, raportul pe care îl constatăm între germ. Schiff 'vapor', Zug 'tren' etc. și fahren: Schiff, Zug etc. aparţin arhilexemului 'vehicul' și fahren înseamnă anume 'a se deplasa într-un vehicul'. Întrucât există câmpuri lexicale şi, în consecinţă, valori arhilexematice de diferite niveluri, există şi selecţii la niveluri diferite. Astfel, de ex., oland. varen este rezervat pentru deplasarea întrun vehicul flotant (barcă, corabie, navă etc.).

5.1.3. În i m p 1 i c a ţ i e, în fine, este vorba de orice lexem determinant care funcţionează în calitate de trăsătură distinctivă în lexemul determinat. Astfel, oland. fietsen înseamnă 'a se deplasa cu bicicleta'; fr. alezan, it. baio, rom. roib etc. sunt adjective ce se aplică cailor.

5.2. Deoarece termenul determinat de o solidaritate implică deja în conţinutul său o parte din lexemul determinant (sau chiar acest lexem determinant în întregime), el poate să se întrebuinţeze de unul singur anume cu această implicaţie, chiar în absenţa termenului determinant. Astfel, senex poate să însemne de unul singur 'moşneag' ('persoană în etate'), întrucât el înseamnă 'în etate' (pentru persoane); ich bin gefahren 'eu am plecat cu un vehicul' implică un vehicul nespecificat şi un alezan 'un roib' se întrebuinţează curent pentru un cheval alezan 'un cal roib'.

5.3. Pentru mai multe detalii asupra solidarităţii cf. articolul nostru Lexicalische Solidaritäten. Poetica 1, 3 (1967), p. 293-303 (versiunea românească - în RLŞL, 1992, nr. 5, p. 37-45; Philologia, 2021, nr. 1, p 7-17).

5.4. Dl B. Pottier admite, de asemenea în această privinţă, o categorie pe care el o numeşte „,virtuèm”, reprezentată prin îmbinări firești şi frecvente în întrebuinţarea lexemelor. Astfel, el consideră că îmbinarea mouette blanche "pescăruş alb" este un fapt de limbă, pentru că există o foarte mare probabilitate ca un pescăruş să fie alb şi pentru că, de exemplu, există o probabilitate foarte redusă ca albă să fie o măslină. Or, acesta este un fapt care se referă la lucruri şi la proprietăţile lor obiective, şi nu la limbi. Frecvenţa îmbinării adjectivului blanc 'alb' cu substantivul 
mouette 'pescăruş' este în realitate un fapt ce se referă la pescăruşi, şi nu la limba franceză, întrucât 'blanc' nu conţine trăsătura distinctivă 'pentru pescăruşi'. Cheval alezan 'cal roib', din contra, este un fapt de limbă, deoarece alezan 'roib' implică în conţinutul sau anume aplicabilitatea exclusivă la cai. Este adevărat că cheval vert 'cal verde', cheval bleu 'cal albastru' pot fi îmbinări mai rare decât cheval blanc 'cal alb', însă aceasta n-are nimic lingvistic, pentru că 'blanc' nu este solidar din punct de vedere lingvistic cu 'cheval' şi 'vert', 'bleu' nu sunt determinate lingvistic ca 'neaplicabile la cai'. Trebuie, în consecinţă, să distingem cu grijă solidarităţile lexicale curat lingvistice (motivate prin însuşi conţinutul lexemelor) şi îmbinările determinate de proprietăţile obiective sau atribuite de realitatea extralingvistică.

Traducere din limba franceză de SILviu BEREJAN 


\title{
CRITICĂ ŞI ISTORIE LITERARĂ
}

https://doi.org/10.52505/1857-4300.2021.2(314).02

CZU:821.135.1-31.09

\section{EROSUL - DE LA HEROS LA PERFORMANCE}

\author{
NinA CORCINSCHI \\ Doctor habilitat în filologie, conferențiar universitar \\ E-mail: ninacorcinschi@gmail.com \\ ORCID: https://orcid.org/0000-0002-4903-4477 \\ Institutul de Filologie Romană „Bogdan Petriceicu-Hasdeu” (Chișinău) \\ Eros - from heros to performance
}

\begin{abstract}
Cornul inorogului (The Unicorn's Horn) by Bogdan Cretu imposes a new episteme of eros: the experiment that tests the body, which removes taboos, prejudices and shows how far one can compete with one's own body. Intimacy is the only space in which the truth can be articulated, in which you can still be identical with yourself, contemporary with what you are in essence. The novel is also a journey in the history of erotic imaginary; it is a reinvention of the impediment and a rediscovery of erotic tension and intensity. The characters are projections of mythological consciousness, from the perspective of which art is always in full synchrony with life. Cornul inorogului (The Unicorn's Horn) is a novel about eros, death, literature and the electrifying connections between them.
\end{abstract}

Keywords: eros, death, literature, seduction, excess, tension, intensity.

\section{Rezumat}

Cornul inorogului de Bogdan Crețu impune o nouă epistemă a erosului: experimentul care pune în probă corpul, care înlătură tabuurile, prejudecățile și arată până unde se poate ajunge în competiția cu propriul trup. Intimitatea este singurul spațiu în care se mai poate articula adevărul, în care mai poți fi identic cu tine însuți, contemporan cu ceea ce ești în esență. Romanul e și un periplu în istoria imaginarului erotic, e o reinventare a impedimentului și o regăsire a tensiunii și a intensității erotice. Personajele sunt proiecții ale conștiinței mitologice, din perspectiva căreia arta e mereu în deplină sincronie cu viața. Cornul inorogului este un roman despre eros, moarte, literatură și conexiunile electrizante dintre acestea.

Cuvinte-cheie: eros, moarte, literatură, seducție, exces, tensiune, intensitate.

Cine citește cu atenție textele de critică literară ale lui Bogdan Crețu, nu are cum să nu remarce în ele și sensibilitatea prozatorului. Discursul percutant al hermeneutului e narativizat de combustia lui ideatică, asociativă, de suplețea 
stilului (uneori de o putere de nuanțare superioară textelor despre care scrie) și de modul empatic, organic chiar, în care se raportează la literatură și se lasă sedus de ea. De aceea, n-ar trebui să ne uimească faptul că romanul său de debut Cornul inorogului (Polirom, 2021) e de o maturitate care se întâlnește doar la meseriașii cu mâna îndelung exersată.

Cartea își așază înțelesurile pe câteva paliere narative: erosul, moartea, literatura și conexiunile lor electrizante, formând prin intensitatea gesturilor şi acțiunilor personajului principal, Dinu Zărnescu, un circuit energetic de o tensiune maximă.

Dinu este scriitor și profesor universitar de literatură. Este un personaj de succes, romanele lui sunt apreciate, cariera universitară e una mulțumitoare, are charisma și șarmul care-i asigură mulți prieteni și admiratori. Dar când îi moare tatăl, o umbră destinală pune în cumpănă aparențele unei realităţi împlinite. În viața lui se produce o acută criză de conștiință de o gravitate derutantă, strivitoare prin înțelegerea că de acum încolo nu se mai poate ascunde. În fața morții tatălui, trebuie să-și asume curajul propriei vieți. Tatăl său, un absolvent excelent al facultății de chimie, autor de brevete și descoperiri în domeniul agrochimiei, un cercetător de succes la un institut academic, este pedepsit de autorități pentru că semnase apelul lui Paul Goma din 1977 și refuzase, la insistența lor, să-și retragă semnătura. Curajul l-a costat scump, fiind detaşat undeva în provincie, în satul Fălciu, ca inginer chimist. Acolo își întemeiază o familie în care se naște Dinu. Ratarea carierei de savant îl frânge, sfârşind ca un alcoolic cirozat. Stigmatul tatălui, mutat pe o orbită greșită a destinului, se transmite fiului. Nașterea lui Dinu este direct legată de condiţia de condamnat a tatălui său, nevoit să trăiască altă viaţă decât cea pe care ar fi meritat-o: „S,i eu sunt un efect al pedepsei, fac parte din ea”. El va resimţi acut vina de a fi fost un produs al destinului frânt al părintelui, de a se fi născut în scenariul unei existențe falsificate, ultragiate, înstrăinate de la direcția ei firească. De aici, neliniștea curioasă a fiului, căutarea în vacarmul uniformizant al existenței a formei care să definească adevăratul-fiu-al-tatălui-său-adevărat și a reflexelor eului contemporan cu sinele său.

Dinu are convingerea că spaţiul public nu mai produce semnificație, este privat de înțelesuri adevărate, care se pierd în ideologie, în retorică, în mărunte lupte de putere. Adevărul se ascunde dincolo de cortine, în intimitate, acolo unde se verifică simțurile, se testează receptorii, se probează visceralitatea. Conștiința morții va acutiza la limită simțirea erotică a personajului. Moartea, al cărei prag îl pipăise cu privirea, și erotismul sunt singurele experiențe-limită care îi pun ființa în cumpănă. Pentru împătimitul de literatură, acestea două (moartea și erotismul) au o cheie de boltă: filtrul estetic. „Erotismul e un act cultural, el presupune inițiere, lucru cu sine și mai ales recuperare a primitivismului. Primitivi mai putem deveni filtrându-ne simțurile prin cultură - asta era convingerea lui Dinu Zărnescu și asta voia să verifice aici" (Crețu, 2011, p. 55). Primitivismul, râvnit de personaj, presupune recuperarea candorii într-o civilizație prea plină de ea însăși, epuizată de propriul discurs, de propriile dogme. Reîntoarcerea la primordial ar fi șansa ruperii de cutume și forme anchilozate, posibilitatea existenței de a se revigora și a căpăta noi înțelesuri. 


\section{Pil Billologita}

\section{Naturalizarea artei, estetizarea vieții}

Dinu se simte atras de acel dincolo, după care lucrurile, viața, oamenii să-și recapete puritatea, incandescența primară. „Naturalețea radicală” la care aspiră e, pentru el, un proces de metabolizare estetică a vieții. Realitatea nu are relevanță în sine decât dacă e fabricată și integrată literar, dacă se ficționalizează. Iar pentru a se aprofunda uman și nuanța literar, existența trebuie împinsă în exces și verificate spaimele și ororile ei. Excesul care pune în tensiune, care sperie și fascinează. Asta ar trebui să facă artistul cu propria viață pentru a stoarce sensuri noi. Dinu Zărnescu ar vrea ca arta să nu mai fugă de realitate, să nu se lase sedusă de propriile ei accesorii, ci să coboare - cu riscul fracturilor și suferinței - în carnalitatea existenței, în viscerele vieții, în tenebrele ființei. În acest sens, modelul lui artistic este artista Marina Abramovici și experimentul ei estetic, în care-și pune la bătaie propriul trup pentru a înțelege până unde poate merge animalul eliberat din om. Ce spații străbate fantezia umană, atunci când „întră într-o convenție”. „...șii-ar fi dorit să poată să-și ducă scrisul la limita la care își dusese Marina trupul și să-și asume scrisul așa cum își asumase ea arta performance" (ibidem, p. 47). E, de fapt, condiția artistului care plătește cu propriul sânge, cu tendoanele corpului său prețul artei. Un alt model - de această dată literar - este scriitoarea Iza Weingold, admirată de Dinu pentru ,verva, vitalitatea, patima" cu care lua în posesie realitatea. Aceste femei au ceva în comun: sunt contemporane cu ele însele. Nu trișează. Arta lor e corporalizată, în sensul în care se nutrește din ritmul lor sangvin, din zbaterea pulsului din carne, transmite suflul lor inconfundabil de sensibilitate.

Fugind de banal, de normalitatea cotidiană, Dinu mută convenția literaturii în existență. Convins că literatura e o esențializare și o estetizare a vieții (ficțiunea este concentrare a esenței realului, este normativă, scria undeva Bogdan Crețu), personajul își va însoți trăitul la limită cu scrisul la limită. Reacțiile viscerale vor fi analizate cu migală, iar deasupra lor se va așterne pânza vaporoasă a stratului literar. „Singura formă veritabilă de risc e cea fizică”, deci va risca cu propriul trup, conștient că ,asta era miza, să-și împingă trupul dincolo de limită prin scris”.

Dacă în spațiul public premiile, funcțiile, onorurile sociale îl lasă aproape rece, în planul intimității, Dinu se va autoprovoca, dar, mai ales, se va lăsa provocat. Își va inerva simțurile, le va testa prin înfometare și exces, le va controla prin disciplină și austeritate.

Jocul intimității devine unul destinal când o întâlnește pe Diana, discipola Marinei Abramovici, artista performance-lui. Frumoasă și fascinantă prin radicalismul cinic, Diana îi induce gustul fatalității. Îndrăgostit de ea, Dinu plonjează în spațiul intimității lor cu senzorii la limită. Corpurile lor se ating, dezlănțuindu-se până în pragul hybrisului. Acestea sunt regulile jocului propus de Diana. „Hai să procedăm altfel decât e normal, ce zici? Altfel? Da, hai să nu facem ce e de făcut, hai să nu ne culcăm unul cu altul, oricum am fi ajuns mai departe, dacă am fi făcut-o de la început, să împingem starea asta până la demență, până la puritate, vrei să încercăm? (...) pentru că va veni și momentul când nu vom mai putea să rămânem lucizi, când animalul va câștiga, până atunci să-1 hrănim cu șoareci de câmp și cu pui de fazan, și cu alte făpturi nevinovate" (ibidem, p. 68). 
Prin tehnica abstinenței se încearcă acumularea tensiunii care să ridice actul erotic la amplitudinea lui maximă. Austeritatea sexuală e orientată spre o ceremonializare a erosului, perceput ca scenariu estetic al simțrilor, nu ca efect grosier al penetrării fizice. Prin practica abstinenței, Dinu și Diana își propun să ridice erotismul la demnitatea artei, să-1 ordoneze estetic. Să-1 aducă la puritate și intensitate, după o intensă metabolizare a tensiunii senzoriale. „Pentru ca ceea ce era între ei să rămână pur și intens trebuiau să respecte regula provizoratului: se vor întâlni când și când, în rest își vor scrie, dar vor refuza să-și amestece carnea, vor acumula tensiune și vor face în așa fel încât trupurile lor să se apropie numai atunci când vor smiorcăi că nu mai pot îndura presiunea..." (ibidem, p. 69).

Așadar, Diana îi propune testul trupului. Ca timp de un an să-și înfrunte limitele. Să performeze erotic prin aventuri sexuale cu alte femei, care să-l dezbrace de tabuuri, de pudori, de prejudecăți, de inerții. Să transgreseze limitele propriului corp. Acest exercițiu mai presupune să se aplice pe trunchiul existențial carcasa convenției literare, „să caute femei interesante, tot mai interesante, să fie asta un fel de creație, ca și cum ar construi niște personaje" (ibidem, p. 71). Să-și ajusteze perfect corpul cu scrisul, viața cu textul. Să ajungă să (se) ințeleagă, pentru că doar ordonat în scris, plonjonul în apele tulburi ale existenței devine inteligibil, își capătă coerența și sensul.

\section{Desenul mitologic din covor}

Trecut prin filtrul literar, putem spune că prin acest joc personajele reînvie impedimentul - vechiul cronotop erotic, garantul pasiunii, cel care ține vie incandescența, tensiunea și teroarea tensiunii. Adică intensitatea. În romanele medievale impedimentul crea distanțe care, îndepărtând îndrăgostiții - îi apropia și mai tare. Primii îndrăgostiți ai literaturii marchează o tradiție a intensificării iubirii prin obstacol, prin perpetua neîmplinire a proiectului erotic. Lipsa de tensiune a generației sale („noi pentru cine mai luptăm azi? Cum ne mai „probăm libertatea?"), invocată de Dinu Zărnescu, e și o lipsă a tensiunii erosului. O diluare a conștiinței erotice a omului de azi. După ce erotismul și-a scos la vedere toate secretele, după ce i s-au stins spectrele de lumină și i s-au așezat energiile, cum să mai răzbată de sub straturile timpului fosforescenţa lui dintâi? Vibrația misterului? Tremurul tainei inefabile? Postmodernitatea și-a epuizat resursele mistice, conștiința îndrăgostitului de astăzi s-a anemizat, și-a tocit reliefurile, s-a diluat în comoditate și confort. Cine ne mai împiedică azi să iubim? Părințiii? Societatea? Cenzura politică? Ideologia? E limpede că sentimentele s-au blazat, au ieșit din tabuuri, că erotismul a pierdut mirarea și spaima. Imaginația erotică, prinsă în țarcul conformismelor, s-a cumințit, s-a diluat. Realitatea, ca să se încarce semantic, își caută reflexele în cultură, se primenește estetic. Existența personajelor își probează șansa de reprezentativitate simbolică în conștiința culturală. Trăitul trebuie să palpite în scris, ,,pulsul să treacă în text”. Transferată în planul mitologic, Diana e (și) o zeiță a vânătorii; tot de acolo, inorogul e ,puritatea instinctului”, e sexualitatea nudă. Diana, conștiința mitologică a romanului, îl pune pe Dinu în fața problemei de recuperare a impedimentului. „Tu nu înțelegi? Trebuie să pui mereu obstacole între tine și mine, obstacole adevărate, care să te 


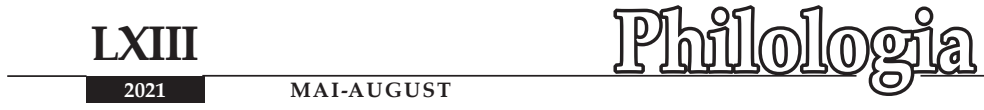

intereseze cu adevărat, să te confiște, să te bulverseze, să te seducă, să te oripileze, să te facă să nu mă uiți..." (ibidem, p. 84).

Astfel, încercările trubadurești, spectacolul masculinității de sub balconul iubitei, când eros îl invoca neapărat pe heros, se transformă, în romanul lui Bogdan Crețu, în exercițiu de performance postmodern. Erosul ca performance presupune o confruntare. Nu e o confruntare cu un obstacol exterior, cu părintii, cu societatea, cu un rival, rivală etc., ci cu propria interioritate a personajului, în hrubele întunecate ale corpului, în lumea nebuloasă a intimității. Diana este zeiţa vânătorii, ,iubita inaccesibilă”, care-și îndepărtează și pedepsește adoratorii. E pretextul mitologic, care invocă goana, neliniștea, starea paroxistică, pentru a atinge nivelul superior al trăirii senzoriale. Rolul ei e să-l arunce în luptă pe Dinu Zărnescu, ,trebuie să treci câteva probe ca să ai dreptul la mine". Să-l determine să se reinventeze, punându-se in probă. E îndemnul situării corpului în tensiune, e excitarea la limită a simţurilor, e lunecarea din jos în mai jos pentru a se atinge straturile ultime ale decăderii, ale mirării-şi-descoperirii-de-sine, pentru a ieși, astfel, înnoit de acolo: „trebuia să-și oripileze simțurile, să le umple de scârbă, în așa fel încât ele să se cumințească și să fie mai întâi stupefiate, șocate, să-și lingă rănile, smiorcăindu-se undeva în întuneric, apoi să redevină, ușor-uşor, firești, alerte, mereu la pândă, dar, oricum, ieșite din isterie" (ibidem, p. 74).

Rolul Dianei e dublu - conștiință mitologică și expresie a hybrisului erotic, rămânând, în consecință, o himeră, o prezență destinată absenței, perpetuei căutări imaginare. Poate de aceea Dinu simte că pasiunea alături de ea - mistuitoare, anulând-o pe cea a scrisului, adică depersonalizându-l-ține de regimul imposibilului.

\section{(Im)puritățile intimității}

Dinu are o certă vocație erotică. Așa cum Don Juan-ii își aleg victimele nu printre femeile frumoase în mod convențional, ci printre cele interesante - precum le numea Don Juan-ul lui Kierkegaard ( Kierkegaard, 1992, p. 66) pe cele înzestrate cu grația expresivă a feminitătii -, Diana și-a ales drept „discipol” (nu se voia maestra lui?) un bărbat cu vocația nu a iubirii, ci a erosului, a senzualității. Care-i va putea vorbi femeii pe limba corpului ei. Într-un exces de sinceritate, Ana va defini exact tipul inteligenței lui erotice bine calibrate: „Tu, Dinu, tu ești păpușa perfectă, ești golanul simpatic, ești vibratorul nostru comun!”. Și când va hotărî să-1 pedepsească, îl va sfida în chiar vocația lui de amant, refuzându-i corpului vibrația la atingerile lui.

Senzualitatea acestui bărbat ia uneori proporții paroxistice. Se pare că, deși este un erudit, cunoașterea lumii îi vine nu din raţionamente și teorii, ci dintr-un continuum senzorial al realității. Reușește să-și prezerve în erotism uimirea, spaima și stângăcia - adică fascinația. În acest fel, conservă misterul, ocrotește taina. Literatura 1-a învăţat să nu aibă prejudecăți în alegerea partenerelor. La fel ca și personajul lui Proust, e capabil să se lase captivat de feminitate în ipostaze dintre cele mai variate, disonante, ieșite din convenție. Excepție face doar impostoarea literară, femeia care reprezintă un atac la ceea ce iubește el cel mai mult - literatura. $\mathrm{Cu}$ fiecare femeie își potrivește din mers - și o face bine - conduita amoroasă. $\mathrm{Cu}$ fecioara Fulvia e tandru și atent, evită gesturile brutale, repezite (pe care le 
preferă „,nerușinata de Marta”, bunăoară), mângâierea lui e o „nici-măcar-atingere”, e o tensionare și o electrizare a aerului din jurul corpului ei de fecioară. Cu Diana, deși o dorește nebunește, reușește să se mențină mereu în secunda care precedă hybrisul. $\mathrm{Cu}$ Ana (care i-ar fi fost perechea ideală, dar ea nu-i răscolea viscerele) trăiește armonia erotică, extazul reciproc al corpurilor. Pentru Venera are tandrețea pe măsura suferinței ei. Pentru Medeea la fel, îi însoțește - ca un ecou - strigătul de crepuscul al tineretii.

Toate femeile care intră în viaţa lui Dinu sunt ipostaze ale femeii și ale erosului, dar și trepte săpate în galeriile lui interioare. Și, pentru că viața își probează sensurile în reprezentările ei artistice - sunt și peripluri prin istoria literară a imaginarului erotic. Emancipata Diana e „un semn al fatalității”, e erosul magnetic, pasional, adus la nebunie. Ana e iubirea statornică, ocrotitoare - tentația lui agapé, conciliat cu philia și eros. Maribelle este reflexia platoniciană a erosului, adorația frumuseții pure. Marta e erosul nestăpânit și obraznic, Sidonia e ultragierea spiritului, ,impostura literară” (,dintre toate încercările lui din ultima vreme, asta fusese cea care-1 chinuise cel mai tare, care-1 făcuse să se disprețuiască, să se simtă murdar, scârbit de sine"), iar Olimpia e însăși limita, e umilirea trupului, e victoria (dar și înfrângerea) animalului care se ascunde în întunericul simţurilor.

Toate aceste căutări în viscerele femeii sunt rătăciri în abisul propriei identități. Pentru a se cunoaște pe sine, Dinu recurge la celălalt, cu care să parcurgă un spațiu al purei intimități. Ințtelege că doar prin exces acest nivel aproape imposibil de intimitate poate fi captat. Expresia radicală a limitei este intrarea în moartea în care cei doi nu mai sunt discontinuități separate, ci ating pragul continuității infinite, într-o pulsaţie identică de „natură metafizică” (Evola, 2006, p. 158). Exemplul intimității liminale i-1 oferă lui Dinu cuplul Aliona și Șerban: „A merge până la capăt cu intimitatea, până la culmile intensității înseamnă intensificarea instinctului morții și râvna infinitudinii. E nevoia de absorbție a celuilalt, dorința furibundă de-al asimila pe celălalt în intimitatea ta, în cercurile ei mistuitoare de foc. Și arderea ta în el, așa încât sentimentul chinuitor al diferenței să se topească într-un aliaj nou, al celor doi deveniți unul. Nu iubire, că nu despre iubire e vorba aici, ci această febră a intimității a pus în mâinile celor doi obiectul morții, a calculat mișcările, a fixat unghiul, a străpuns cu exactitate matematică cordul celuilalt" (ibidem, p. 158). Arta desăvârșită a cruzimii, pe scena intimității lor, provoacă spaima, laolaltă cu admirația și fascinația lui Dinu Zărnescu. Iată un prag paroxistic, în care trupul de carne devine contemporan cu fenomenalitatea lui culturală și ipso facto emoțională!

\section{Venerele lui Dinu}

Femeile care-1 marchează pe Dinu au un semn distinctiv comun. Iza avea o cicatrice pe partea din spate a coapsei drepte, Diana și Ana aveau o cicatrice pe reversul coapsei drepte, la fel, Medeea și Venera. Cicatricea de pe coapsa Statuii Venerei Capitolina o poartă femeile lui Dinu ca pe un însemn al faptului că „arta e convenția viului”. Iar ele sunt niște Venere umane, reprezentări vii ale artefactului, demonstrând că frumusețea este vulnerabilă. Și perisabilă. Oricând poate fi rănită, spintecată, vandalizată, dizolvată. Frumusețea nu e ceva diafan și vaporos, despărțit categoric de obscen, de vulgar, de morbid. Trupul 


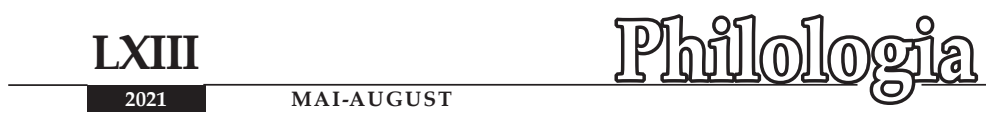

e un loc al suferinței și al memoriei suferinței, iar primele indicii ale degradării trupului, primele semne vestitoare ale morții pot însoți formele cele mai splendide. În imaginația lui Dinu, trupul gol întrunea împreună frumusețea cu suferința. Prima dată văzuse un trup gol la femeile din lagărele morții de la Auschwitz și Buchenwald, unde femeile erau dezbrăcate și duse către moarte. „Niște soldați aveau armele îndreptate către ele, iar lui i s-a părut că aceștia se apără, că trupurile goale sunt mai amenințătoare decât puștile și pistoalele. Goliciunea strălucea mai tare decât oroarea; în plus, amestecul de sexualitate strivită, umilită și brutalitate îl cutremura” (ibidem, p. 299). De atunci „A asociat mereu trupul gol al femeii cu sentimentul de vinovăție”, iar ,ideea de sexualitate a rămas cumva legată de cea de tragedie, de moarte, de suferință". Moartea însoțește, în felurite chipuri, orice formă de viață și lecția pe care i-o dă Venera lui Dinu e că moartea trebuie acceptată, suferința trebuie îmblânzită și îngrijită, ca pe un membru schilod al familiei, așa cum își îngrijește ea fiul, pe Dănuț, - cu blândețe, cu resemnare senină și acceptare. Scena de iubire a lui Dinu și Venera în cada cu apă e o uniune a contrariilor temporale și metafizice: a copilăriei și maturității reîntâlnite într-o imagine cronotopică a fetiței devenite femeie, prin actul păgân al privirii. E și trăire a extazului vieții în vecinătatea morții care dormitează răbdătoare în camera lui Dănuț, o declanșare a bucuriei disperate a simțurilor, a jubilației clipei, a frumuseții de miracol al vieții, pe care se citesc umbrele suferinței permanente, veghind aici, aproape, alături. Existența sordidă, banală își capătă temeiul prin artă. Se înnobilează prin literatură. Vera e o Veneră împământenită, ducând cu ea, în spatele coapsei drepte, semnele memoriei unei frumuseți ideale, ale Venerei celeste, aurorale, din memoria de copil a lui Dinu.

Gloria atinsă de însemnele morții a gladiatorului din Muzeele Capitoline este un alt reper cultural al interferențelor existenței cu literatura. Imaginea bărbatului rănit reprezintă un prag între viață și moarte, o suspendare epifanică a timpului cronologic. Privirea asupra sângelui de pe corpul străpuns de armă semnalează, crede Dinu, ințelegerea. Moartea ca experiență limită deschide accesul la o altfel de revelație. Statuia gladiatorului provoacă și acutizează instinctul erotic, în cel care privește moartea ca pe o imagine statuară. Aventura erotică cu spectatoarea fragilă nu e doar o aventură, e o revanșă a vieții asupra morții, un spectacol erotic oferit morții pânditoare din piatră, o încarnare glorioasă a instinctului vital. Din corpul-obiect al gladiatorului se arată rana și sângele, adică semnele umanitătii muribunde, acest gust al vieții murind vrea să-1 simtă Frida, ducându-și la gură degetul ,înfipt” în sângele reprezentat sculptural. Spectatoarea, intrată în convenția artei, vrea să simtă gustul vieții în cumpănă, al vieții intrate cu un picior în moarte. Iconicul se dilată în narativ, arta trece în existență, contemplația - în trăire, emoția estetică - în senzația viscerală.

Arta și viața se potențează reciproc, prin imaginație. Pentru Frida, venită să privească galul, să-l atingă, Dinu devine uşa de carne, pretextul pentru intrarea în hybris. Energia lui umană amplifică efectul senzorial al contemplării obiectului estetic și declanșează starea de transă, nebunia erotică, şocul, pierderea de sine. Înlănțuirea erotică dintre Dinu și Frida este electrizarea aerului care „,părea de piatră”, e ieșirea gladiatorului din istorie, descătușarea energiei erotice a herosului 
și convertirea acestuia în exercițiu de performance. E instinctul vieții trezit de cel al morții. Iar Dinu acceptă curios provocarea Fridei, urmându-i gesturile, care refuză exprimarea verbală, și - în tăcerea cea mai asurzitoare a simțurilor - face ca întâlnirea dintre el și Frida „să funcționeze exact ca o operă de artă”.

Dintre toate ispitele lui Dinu, suprema Veneră o reprezintă literatura. Visele, fantasmele și pulsiunile lui doar în ficțiune își capătă strălucirea intensă, vigoarea copleșitoare. Pregătirea pentru scris, starea de dinainte, freamătul de până la..., adrenalina în creștere - toate sunt preludii amoroase. Scrisul în sine o voluptate tactilă, mentală, viscerală. $\mathrm{O}$ angajare totală a corpului într-un dans frenetic, ființial: „Se ridica uneori brusc, desena prin aer gesturi dislocate, nefuncționale și dintr-odată se repezea înspre peretele acoperit de cărți și se oprea cu vreo doi centimetri înainte de a se izbi de rafturi, apoi se retrăgea fluid, cu pași de balet, și se prăbușea pe scaunul surpat pe care nu se hotăra să-1 schimbe" (ibidem, p. 107). Neprihănita Fulvia simte pe pielea ei senzualitatea romanului scris de Dinu Zărnescu - energia erotică a cărții o traversează cu voluptatea palmelor unui amant.

\section{Testul lui Swann}

Diana reprezintă inițial un corp-obiect - o ușă de carne, destinată să intimideze și chiar să paralizeze privirea spectatorului. Ceea ce se și întâmplă cu ceilalți spectatori, care treceau „la început ezitând, apoi indiferenți printre cele două corpuri goale, de parcă important ar fi fost să pătrundă cât mai repede dincolo". Dinu încalcă convenția și „umanizează” ușa corporală cu respirația lui fierbinte, cu ochii lui arzători. Depăşind pragul estetic, personajul trece și un prag ontologic. După întâlnirea cu Diana, nimic nu mai e la fel, el trebuie să oblige viaţa să ia forma artei. Și aici intră în scenă Proust. Miza vieții ca performance, la care îl împinge Diana, are în fundal și opera proustiană, mai exact erotismul irigat de cultură a lui Swann (care este și un mediator erotic al întâlnirilor dintre ei). Experiențele erotice ale lui Dinu sunt toate și pretexte literare. Femeile cu care se combină Dinu sunt ipostaze ale lui Odette, care trebuie să se prefacă în Zephora, adică în artă. Nu prin efortul și străduința lor, ci prin imaginația creatorului, a lui Dinu. Prin modul în care el învață să le privească și să le proiecteze în propria lume. Ridicând o femeie obișnuită la demnitatea artistică a Zephorei, Dinu avea șansa să clatine registrul absolutului și al categoricului în care o situase pe Diana.

Trăitul până la capăt este experimentat visceral cu Olimpia și estetic - cu Iza, femeia nobiliară prin curajul și superioritatea conștiinței, acel factotum feminin (e mama Romaniței - fiica poporului român), care știe că a venit momentul când Dinu trebuie să se retragă din concretețea existenței în jocul-totului-posibil, în zborul imprevizibil al splendidului bolid la viteza lui maximă.

Curajul prefăcut în artă e și miza de scriitor a lui Dinu Zărnescu. Să transforme vibrația, incandescența trăirii în text, păstrându-le vii, ducându-le până la ultima consecință a scrisului. Să ajungă toate o rostire intensă a intimității: ,să tremure fraza, să vibreze, căuta un limbaj care să se muleze perfect pe scenă, să gâfâie sau să jubileze, un limbaj tragic sau anodin, sobru sau erotizat, banal ori extravagant" (ibidem, p. 45). Textul lui Bogdan Crețu exact asta face: își ajustează sintaxa la 


\section{LXIII \\ 2021 \\ MAI-AUGUST

ritmul respirației auctoriale, cuvintele se încarcă de carnalitate, exprimând formele reflexive și visceralizante ale sensibilității sale și puterea de somatizare a lumii scrise. Așa cum visa personajul său: „...cu liniile conturului său de om din carne suprapuse milimetric peste liniile conturului său de om făcut din fum, din iluzii, din dorințe care veneau de undeva de departe și care nu aveau nici o legătură cu el" (ibidem, p. 301). De la trup la scris, senzațiile trec în sensuri, percepțiile exterioare se interiorizează, reflecția caută motivații ontologice. Intermitența și fluiditatea stărilor își găsesc expresia pe cât de senzitivă, pe atât de elastică şi senzuală. De la un personaj la altul, de la o istorie la alta, Bogdan Crețu surprinde configuraţia spasmului erotic și dinamica lui fulgerătoare. Declanșarea energiei seducției, circuitul subtil al fluizilor, jocul receptorilor etc. sunt captate în nuanțele lor infinitezimale. $\mathrm{Nu}$ (doar) întâlnirea privirilor, ci zvâcnetul interior, care stă să izbucnească în priviri, nu atingerea, ci vibrația aerului care anticipează atingerea, nu cuvintele, nu doar cuvintele - ci ritmul sacadat al respirației, din care erupe vocea. În spasmul visceral şi pulsiunea semiotică, autorul caută unitatea contrariilor: efluviile de voluptate săgetate de durere, vinovăția și plăcerea, înălțarea și prăbușirea. Astfel, scrisul său se corporalizează intens, se somatizează, respiră.

„Pentru a fi în stare sa deguști natura cu sensibilitatea mereu pânditoare, ai nevoie de cultură”. Iată miza atinsă de romanul lui Bogdan Crețu!

...și o concluzie

Romanul lui Bogdan Crețu probează șansele literaturii de-a se re-umaniza, de-a ieși din ticuri, din inerții, din automatisme. De a-și recăpăta candoarea, prospețimea, intensitatea și, în cele din urmă, vitalitatea. De a-i oferi omului ceea ce acesta riscă să piardă, dacă nu chiar a pierdut - preluând tot mai mult din rolul de pilot automat al mașinii sale - o posibilitate de acces la propria sa intimitate. O întoarcere către sine, prin literatură. „Să trăim totul în deplin acord cu noi înșine, să ne redescoperim ca ființe întregi. Asta e, asta ar trebui să fie literatura".

\section{Referințe bibliografice:}

CREȚU, Bogdan. Cornul inorogului. Iași: Polirom, 2021.

KIERKEGAARD, Søren. Jurnalul seducătorului, trad. de Kjeld Jensen și Elena Dan. București: Scripta, 1992.

EVOLA, Iulius. Metafizica sexului, trad. de Sorin Mărculescu, ed. a III-a. București: Humanitas, 2006.

Notă: Articolul a fost realizat în cadrul proiectului de cercetare 20.80009.1606.03 Contexte socioculturale autohtone şi interconexiuni europene în creaţia populară şi literatura cultă din Basarabia (sec. XIX până în prezent), Institutul de Filologie Română „B. P.-Hasdeu” al MECC. 


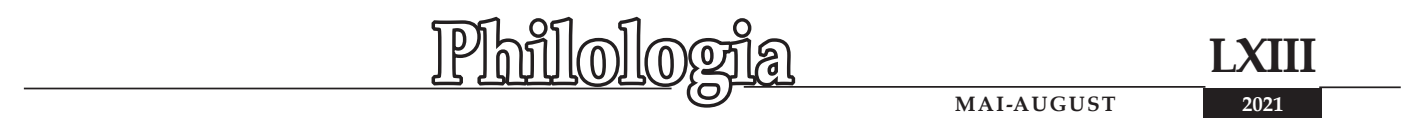

https://doi.org/10.52505/1857-4300.2021.2(314).03

CZU:821.135.1.09(478)

\title{
PAN HALIPPA, UN POET CU ,FLORI DE PÂRLOAGĂ”
}

\author{
Alexandru BURLaCU \\ Doctor habilitat în filologie, profesor universitar \\ E-mail: alexburlacu1@gmail.com \\ ORCID: https://orcid.org/0000-0002-3424-1588 \\ Institutul de Filologie Romană „Bogdan Petriceicu-Hasdeu” (Chișinău)
}

Pan Halippa, a Poet with „Flori de pârloagă”

\begin{abstract}
This article examines the poetry of Pan Halippa, who, like Alexei Mateevici or Ion Buzdugan, started from a special understanding of the canons of poetics. The Bessarabian poets of the Union generation, as well as the Ardelians on the other side of Romanianism, were constantly concerned with the national idea, the ardent ethics, the continuation of a trenchant direction of direct, mimetic poetry based on the way of transfiguration classicizing convention, the poetics of sight, the transitive language. In an essentialized formula, Halippa's poetry is an adaptation of romanticism to samanatorism.

Keywords: minor poet, eclectic poetics, occasional poetry.

\section{Rezumat}

În acest articol este examinată poezia lui Pan Halippa, care, ca și Alexei Mateevici sau Ion Buzdugan, a pornit de la o înțelegere aparte a canoanelor poeticității. Poeții basarabeni din generația Unirii, ca şi ardelenii de la cealaltă margine a românismului, au fost preocupați constant de ideea națională, de eticul ardent, de continuarea unei direcții tranșante a poeziei directe, mimetice care să aibă la baza modalității de transfigurare convenția clasicizantă, poetica văzului, limbajul tranzitiv. Într-o formulă esențializată, poezia lui Halippa este o adaptare a romantismului la sămănătorism.

Cuvinte-cheie: poet minor, poetică eclectică, poezie ocazională.

Poezia şi publicistica literară ale lui Pan Halippa constituie partea cea mai puțin cunoscută, în prezent, de marele public. E creaţia unui scriitor care s-a identificat totalmente cu destinul Basarabiei, iar sensul acestei opere trebuie găsit în contextul său cultural, istoric și literar. $\mathrm{Cu}$ adevărat, nu putem evita măsurătorile justificate de necesităţile culturalului sau de eliadesca teroare a istoriei care, atât de cumplită în Basarabia, a avut, în plan artistic, un impact decisiv şi a marcat profund
\end{abstract}




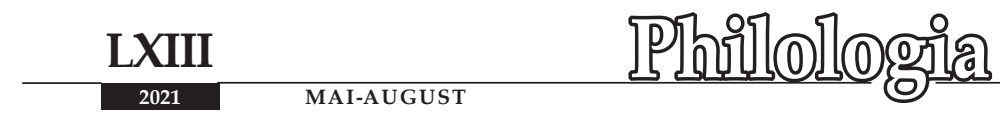

profilul ontologic al scriitorului basarabean. Vedem în aceste considerente un cerc hermeneutic de care, în cazul dat, nu putem face abstracție.

Aflat într-o cronică retardare, scriitorul basarabean ca şi cum lucrează în contratimp. Cum altfel am explica acest post-sincronism permanentizat, fenomen, se pare, specific literaturii române din spațiul pruto-nistrean. Tradiționalismul basarabean e înfătișat de epigonii eminescieni care cultivă convenția clasicizantă, de esență sămănătoristă. Acest tradiționalism e remarcabil prin exaltarea trecutului istoric, a fondului originar, a spaţiului şi timpului dacic sau prin descoperirea folclorului neaoș. Spiritualizarea existenței, transfigurarea particularităților sufletului şi etosului basarabean au mers pe linia puternică a credinței ortodoxe, a accentuării valorilor ei sacre. Oricât de mult am vrea să elucidăm unele atitudini de creație ale condeierilor basarabeni prin conservatorismul lor ancestral sau prin matricea spirituală a spațiului mioritic, nu poate fi neglijată seceta culturală din Basarabia.

Gheorghe Cardaș, în prefața la antologia Poeții şi prozatorii Basarabiei până la Unire (1812-1918), remarcă: „O bună parte dintre cei mai talentați scriitori basarabeni au trecut Prutul venind în principate, unde şi-au tipărit operele lor literare. Dacă Alecu Russo, Costache Stamati, Teodor Vârnav, Alexandru Donici, Bogdan P. Hasdeu, Ştefan Basarabeanu (Victor Crăsescu), Zamfir C. Arbore, Dumitru C. Moruzi, Sergiu Cujbă ar fi rămas în Basarabia sau dacă şi-ar fi tipărit operele lor în această provincie, cultura românească de aici s-ar fi putut menţine mai multă vreme, rezistând în fața nefastei influențe rusești. Chiar şi în domeniul religios şi juridic cărțile cele mai răspândite veneau din tipografiile de peste Prut.

Scriitorii rămași acasă: Ion Sârbu, Alexandru Hâjdău, Alexis Nacco, Matei Donici, Gheorghe Păun, Tudose Roman, Alexe Mateevici, Pantelimon Halippa, Ion Buzdugan şi alții au avut de dus o grea luptă pentru menţinerea limbii spiritului românesc" (Cardaş, 1937, p. 7).

Rămasă fără limbă, fără carte, fără gazetă, făă intelectuali, Basarabia, întradevăr, nu putea să însemne decât o uriașă temniță în care lumina era îngăduită prin ferestruica străjuită dinspre răsărit. În rezistența pe care au arătat-o basarabenii față de ,încercările rușilor de a-i înstrăina, instinctul de conservare a neamului a jucat primul rol" (Ciobanu, 1993, p. 257).

În Istoria literaturii române contemporane. 1900-1937, Eugen Lovinescu comentează scurt pe doi: „De contribuția literară a Basarabiei nu ne putem apropia decât cu interes cultural și cu amorțirea scrupulelor estetice. Numai gândul că unele din aceste versuri au fost scrise înainte de război și că reprezintă, prin urmare, dovezi de continuitate culturală românească dintr-o epocă de înstrăinare ne face să răsfoim, de pildă, Miresme din stepă ale lui Ion Buzdugan sau Poeziile lui A1. Mateevici, cu o poezie citabilă (Limba noastră) și chiar Flori de pârloagă ale lui Pan Halippa" (Lovinescu, 1989, p. 68-69).

S-a afirmat şi se afirmă, pe bună dreptate, că peste poeții români din Basarabia a trecut Neantul. Este un adevăr incontestabil, desigur, pentru o bună parte dintre poeții generației Unirii, pentru acei care au exprimat cu necontrafăcută sinceritate amarul înstrăinării, cântarea pătimirii noastre, dar fără o capacitate de expresie. Capacitatea aceasta se câștigă în timp. Cei mai mulți dintre ei, cu adevărat, n-au 
avut timp să se gândească la formă, la ,inginerii verbale”, la „arabescuri virtuoase”, la manierisme năucitoare.

Pantelimon Halippa, poet, publicist și memorialist, s-a născut la 1 august 1883 în comuna Cubolta, județul Soroca. După studiile făcute la Școala duhovnicească din Edineț, apoi la Seminarul Teologic din Chișinău (1898-1904), a decis să renunțe la o posibilă carieră ecleziastică și s-a înscris la Facultatea de Științe Naturale și Agronomie a Universității din Dorpat (Iuriev, astăzi orașul Tartu, Estonia). Participă la grevele studențești din 1905; ia parte la Congresul Uniunii Țărănești de la Moscova, ca delegat din partea tăăănimii basarabene. Impreună cu Constantin Stere și Ion Pelivan, editează la Chișinău (1906) prima gazetă în limba română Basarabia, semnând mai multe articole cu pseudonimele Pintilie Cubolteanu, Pintilie Basarabeanu. Mai târziu, se înscrie la Facultatea de Litere și Filosofie a Universității din Iași (1908-1912). Susține rubrica Scrisori din Basarabia în revista Viața Românească. Revenind la Chișinău, fondează împreună cu Nicolae Alexandri ziarul Cuvânt moldovenesc, în paginile căruia pledează pentru interesele naționale ale românilor din Basarabia. Colaborează şi la publicaţiile Ardealul (Transilvania), România nouă. În anul 1917, după abdicarea țarului Nicolae al IIlea, Pantelimon Halippa a creat Partidul Naţional Moldovenesc. A negociat dreptul românilor basarabeni la autodeterminare cu Kerenski, Lenin și Troțki. A fost ales vicepreședinte, apoi președinte al Sfatului Țării din Basarabia, a obținut votarea Unirii Basarabiei cu Regatul României. În 1918, el a luat parte la adunările din Cernăuți și Alba Iulia, care au decis Unirea Bucovinei și a Transilvaniei cu România.

În perioada interbelică Pantelimon Halippa deține mai multe funcții, care i-au marcat o carieră politică excepțională: ministru secretar de stat pentru Basarabia, în guvernul condus de Alexandru Vaida-Voevod (1 decembrie 1919 - 13 martie 1920), ministru al Lucrărilor Publice, în guvernul prezidat de Barbu Știrbei (4-20 iunie 1927), ministru al Lucrărilor Publice și Comunicațiilor, în guvernul Iuliu Maniu (10 noiembrie 1928 - 7 iunie 1930), ministru al Muncii, Sănătății și Ocrotirii Sociale, în guvernul Iuliu Maniu (13 iunie 1930 - 10 octombrie 1930), apoi ministru de stat, în guvernele Mironescu (10 octombrie 1930-18 aprilie 1931, Vaida (11 august 1932 - 19 octombrie 1932), Maniu (20 octombrie 1932 - 13 ianuarie 1933), Vaida (14 ianuarie 1933 - 13 noiembrie 1933), precum și senator și deputat în Parlament (1918-1934).

În 1932 fondează la Chișinău revista de cultură generală Viaţa Basarabiei, al cărei director este până la data suprimării publicației (iulie 1944). In 1950 a fost arestat și dus în închisorile din Sighet. După 2 ani, a fost predat autorităţilor sovietice, care 1-au adus la Chișinău, unde a fost condamnat la 25 de ani de muncă silnică în Siberia. Revine în țară în 1955, dar a ajuns tot într-o temniță din Gherla, unde a stat închis până în 1957. Moare la 30 aprilie 1979, la București. Este înmormântat în cimitirul mănăstirii Cernica. A fost membru corespondent al Academiei Române, membru al Uniunii Scriitorilor. A tradus din Pușkin, Lermontov și alți poeți ruși.

Debutează cu poezii în limba rusă în revista pentru elevi a Seminarului Teologic din Chișinău (1901). P. Halippa este autorul studiilor istorice Bessarabia do prisoedineniea $k$ Rossii /Basarabia până la alipirea la Rusia/ (1914), Basarabia sub împăratul Alexandru I (1812-1825) (1914), Bogdan Petriceicu 


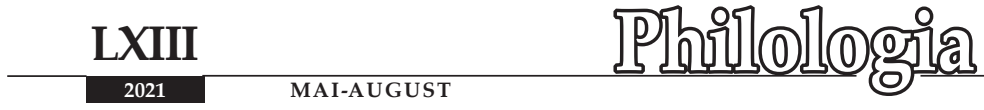

Hasdeu (1939) etc., a volumului de poezii Flori de pârloagă (1912-1920), care a apărut în 1921 la Iași.

Mihail Sadoveanu, în Prefață la Flori de pârloagă, remarca: „Deși adăpat la literatura noastră nouă, deși de timpuriu familiarizat cu marea literatură rusă, Pantelimon Halippa nu purcede nici de la Eminescu, nici de la Coșbuc, nici de la Puşkin, nici de la Lermontov. Poetul Florilor de pârloagă e un produs deosebit al obijduitei Basarabii. El se ridică pe propriile-i mijloace în armonie cu începuturile de cultură ale moldovenilor de peste Prut şi cu nevoile lor sufletești. El este pentru Basarabia ceea ce au fost pentru Moldova şi Muntenia poeții renașterii noastre dinainte de Eminescu" (Sadoveanu, 1921, p. 3).

Specificul acestei poezii stă în vârsta ei necultivată culturalicește. Într-un limbaj accesibil, ea pune în valoare suferința, ,jalea lumii”, propagă ideea mântuirii prin Unire. E o poezie în contratimp, scrisă după alte legi, în contrasens cu mișcarea liricii moderniste. Românii din Basarabia au fost mereu niște întârziați mai în toate domeniile activităţii spirituale. În poezie, de exemplu, Florile din pârloagă par tot atât de exotice și întârziate cam cum apăreau Florile Bosforului (1866) de Dimitrie Bolintineanu în raport cu Florile răului (1857) de Charles Baudelaire. Dar plaga cea mai mare a fost totuşi limba acestei literaturi şi apoi mentalitatea şi complexele ei de inferioritate.

$\mathrm{Cu}$ privire la îndelunga hibernare basarabeană, Nicolae Iorga observa cu acuitate și pătrundere: „Românii din Ardeal şi Ungaria, sau cum îşi zic ei : românii din Ardeal, Banat și Țara Ungurească, pentru că Banatul ține să aibă o situație deosebită, privilegiată, românii aceștia se deosebesc de românii din Basarabia şi de românii din Banat, sub raportul politic, prin aceea că n-au făcut parte din același stat cu noi: românii din Basarabia sunt moldoveni desfăcuți de noi la 1812; până la 1812, viața noastră şi a românilor basarabeni a fost întru toate aceeași. Dacă ar vrea să aibă cineva icoana vieții noastre vechi, de la începutul veacului al XIX-lea, n-are decât să treacă în Basarabia şi să privească rosturile românești de acolo: o să găsească târguri cum erau la 1812, grație bunului guvern rusesc: şi este pentru noi foarte interesant să vedem cum eram cu câtăva vreme înainte. Bieții români basarabeni au fost prinși de gheața rusească cum e prinsă o broască într-un sloi de gheață şi îi găsim astăzi nestricați, întregi, așa cum i-a prins frigul strașnic din bolovanul de gheață" (Iorga, 1908, p. 17-18).

Literatura română din Basarabia, în derutele începutului, a crescut în umbra culturii rusești sau, cel puţin, a avut în față modelele rusești. Odată cu acestea, ea, prin subconștient sau memorie genetică, a reconstituit eclectic şi într-un timp scurt/ condensat momente istorice de la iluminismul Școlii ardelene la sămănătorism/ poporanism sau de la sămănătorism la neo-sămănătorism, conjugat cu gândirism, şi, rar de tot, a încercat să se sincronizeze cu căutările moderniste ale literaturii din centru.

Pentru Nicolae Iorga, Pan Halippa e un ,vechi scriitor sincer, într-o formă naivă, dar bun traducător din rusește" (Iorga, 1985, p. 280). În același sens, George Călinescu nota: „Ceea ce este simpatic la Pan. Halippa, ca la basarabeni în general (mai putem cita pe I. Buzdugan), este acea vorbire apăsată care sună pentru urechile noastre de azi cum trebuie să sune pentru francezi franțuzeasca 
canadienilor" (Călinescu, 1986, p. 941). Călinescu găsește citabile trei strofe din Poezie-datorie:

„Într-o zi din cea junie

Am jurat, așa în hohot,

Să mă las de poezie,

Zăvorând cuvântu-mi slobod.

Dar cuvântu-mi dat năprasnic

L-am călcat de-atunci mereu

Și la tristul vieții praznic

Cântu-a fost prinosul meu...

Și eu cânt atuncea viața

Moldovenilor din sate,

Ce orbecăiesc prin ceață

De dureri nenumărate"

În înțelegerea lui Pan Halippa, poezia e, înainte de toate, o obligație morală, impusă de sentimentul de dreptate: „Viața m-a-nfrățit cu jalea,/ Jalea m-a-nfrățit cu cântul,/ Cântecu-mi deschise calea/ Să fiu frate cu pământul" (Cântul meu), iar poetul, ,frate cu pământul”, este, în inerția liricii profetice, alesul care cântă jalea mulțimii, exprimată nu fără un (afișat) gigantism în forme și ritmuri energetice:

„El inima-și struni și prinse

Să zică doină fermecată

În vorbe de oțel, aprinse,

Ca-n pieptul altor să răzbată.

Părea că foc îi suflă gura,

Că-n pieptu-i clocotesc vulcane

Şi versul, sclipitor ca zgura,

Cădea în ritmuri de ciocane.

Durerea lumii el plângea

Și lumea-i răspundea-n suspinuri,

Căci chinul lui se înfrățea

$\mathrm{Cu}$-ale mulțimii grele chinuri”

(Poetul-luptător).

Pan Halippa, ca și Alexei Mateevici sau Ion Buzdugan, a pornit de la o înțelegere aparte a canoanelor poeticității. Poeții basarabeni din generația Unirii, ca şi ardelenii de la cealaltă margine a românismului, au fost preocupați constant de ideea națională, de eticul ardent, de continuarea unei direcții tranșante a poeziei directe, mimetice, care să aibă la baza modalității de transfigurare în convenția 


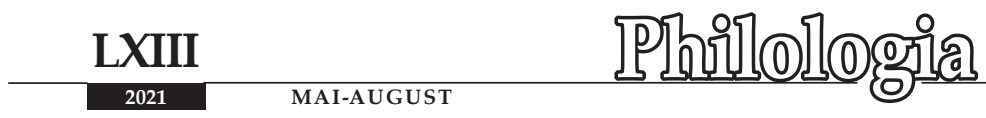

clasicizantă poetica văzului, limbajul tranzitiv. Direcția aceasta a fost şi rămâne tentantă și fertilă, la noi, pentru lirica patriotică, profetică, vindicativă pe tot parcursul secolului trecut. Definiții ale poeziei sau ale statutului poetului vor reveni în ,spiritul timpului” în instantanee de romantism autentic:

„Vreau spirit de proroc

Și inspirații sfinte.

Să ard cu bici de foc,

S-audă din morminte

Și morții glasul meu"

(Poem).

Subiectul ,pătimirii noastre”, din pledoariile publicistice ale lui Pan Halippa, revine constant mai cu seamă pe paginile revistei Viața Basarabiei. Poezia aceasta, deliberat tradiționalistă, are în prim-plan pe rapsodul Plugarului: „Cântul meu e cânt de slavă/ Pentru-a plugărimii gloată;/ În orașe, cu-a lor pleavă,/ În zadar el rost își cată”. Conflictul dintre sat și oraș, ca un dat ineluctabil, inspirat de programul sămănătorist, se schițează și în opoziția dintre prezentul mizerabil și trecutul glorios: „În aleea mare, unde-i umbra deasă,/ Stau bătrâni pe bancă, cu luleli aprinse:/ Ei bârfesc prezentul și din greu oftează,/ Scormonind trecutul cu amurguri stinse" (In parc).

După modelul sămănătorist, stihuitorul caută frumusețea în etosul și etica „sănătoasă”, plină de poezie a satului. Țăranul, evocat în straie de sărbătoare, în armonie cu natura, este fericit de „sârjoaca înspicată/ Pe întinsele ogoare”: „Casa mică țăănească/ Este așa de încăpătoare/ Pentru el ca să domnească/ La o zi de sărbătoare!// A lui locuri îndrăgite:/ Codrul verde cu poiene,/ Șesul cu cirezi de vite,/ Câmpul plin de buruiene;// Și nimic în lumea toată/ Nu-1 încântă-așa de tare,/ Ca sârjoaca înspicată/ Pe întinsele ogoare!" (Cântul meu). Dar odată cu acestea, locul imaginarului edenic îl ia povestea unui neam robit: „Cetind a neamului poveste,/ o jale mare făr-de veste/ se naște-n sufletu-mi trudit./ Azvârl atuncea cartea tristă,/ M-așez afară jos pe prispă/ Șỉ-n juru-mi caut obosit./ Și iar priveliști triste văd,/ Căci frații tot în lanuri șăd,/ Robia veche tot domnește./ În juru-mi văd, ca în trecut,/ Un neam robit, un neam bătut/ Și simt că-un plâns mă podidește" (Pe scoarța unui letopiseț). Ștergând colbul de pe cronici, Halippa e tentat, de acum încolo, să renască virtuțile unui ,neam robit”, să-1 lumineze, să ridice în cultură „neamul bătut”.

Poetica lui Pan Halippa este evident eclectică, reconfigurând câteva vârste ale poeziei: iluministă, sentimentalistă, un amalgam de elemente romantice impregnate cu idei poporanisto-sămănătoriste; în linii mari, conturează traiectul unei poezii posteminesciene, de orientare conservatoare, specifice etapei de tranziție de la începutul secolului trecut. Într-o formulă esențializată, poezia lui Halippa ar fi o ,adaptare a romantismului la sămănătorism” (Radu G. Țeposu). Temele și motivele sămănătoriste alternează cu călătoriile în „,munții prăpăstioși” cu ,pereți de stânci cernite" (Munții), cu transfigurări în simbolistica revoluționară (marea, furtuna, albatrosul) în spiritul celebrului Albatros al lui Maxim Gorki, invocate și în publicistica sa: 
„Se-nalţă albatroșii, Apoi ca pietre pică, Și-n zborul fulgeratic Șuviți de-argint despică.

O, suflete bicisnic, La lupte te avântă! Ia pildă de la mare, Pe ea furtuni o-ncântă..." (Marea Neagră).

Poeme ca Marea Neagră, Poetul-luptător, Poem, Poezie-datorie, Cântec de leagăn ș.a. (nu multe la număr!) arată o cu totul altă față a creației lui Pan Halippa, în care poetul e identificat cu poezia prevestitoare de o nouă epocă. Poezia e inclusă în existența lui sau viceversa: destinul/ biografia lui spirituală e turnată în poezie, dar care totuși abundă în clișee.

Într-o formă esențializată, vocea poetului se contopește cu vocile predecesorilor: „Lan de spice, lan de aur,/ Cât privești cu ochiu-n zare./ Scump nemărginit tezaur,/ Străbătut, scăldat de soare...// Vânt șăgalnic unduiește/ Pânza limpede de fire.../ Fiecare fir trăiește/ Zile dulci de fericire...// Spic cu spic se pupă-n gură/ Într-o dragoste curată./ Soarele cu a lui căldură/ Le aprinde, le îmbată...// Ciocârlia-n cer albastru/ Cântă-n voie, cum i-i placul:/ Undeva în loc sihastru,/ Îi răspunde pitpalacul.// Aerul e plin de miros/ Si de sunete ușoare,/ Parc-ar fi un cânt din cliros,/ Adiat de-o slabă boare..." (Lan de spice).

Modelul Alecsandri transpare în mod firesc, dar măreția naturii din poezia „bardului de la Mircești” e contrapusă ideii nimicniciei ființei. Omul e judecător al tuturor lucrurilor, dar, în trecere pe pământ („Și tu om, martor pe-aice”), e nimic în „clipa cea repede”, un „vierme al pământului” în fața veșniciei, infinitului: „Tot cuprinsul i-o minune.../ Și tu om, martor pe-aice,/ Nici-un chip n-ai a nu spune:/ Sunt nimic, dar sunt ferice!” (ibidem). Poanta „Sunt nimic, dar sunt ferice” aruncă o nouă lumină peste întreaga lui lirică peisagistică.

Ritmurile și atmosfera campestră au ceva ce amintesc de idilele lui George Coșbuc: „Sara caldă, liniștită/ Se topește-n raze stinse/ Miroasă a peliniță/ Din câmpiile întinse...// Năvălesc timide umbre/ Îmbrăcate-n fum subțire./ Biruit de somn și lene/ Totul trece-n nesimțire.// Visuri blânde, ca vedenii,/ Vin încet, cu pas himeric.../ Cere inima-mi hodină,/ Liniște și întuneric...// Și din largul stepei mute/ Vântul pare că-mi îndreaptă/ Șoapta lui liniștitoare: «Fii cuminte și așteaptă!»" (În stepă).

Nu mai puțin elocvente sunt versurile din Toamna, in grădină sau Iarnă: „Cade cel dintâi omăt,/ Frigul se tot întărește,/ Gospodina iarnă-ncet/ Pânza albăși nevedește.// Lucrul iernii e-ntr-ales:/ Fir de-argint cu râvnă pune,/ Și când cați spre largul șes -/ Te orbește, i-o minune...// Și omătul cade-ntruna,/ Aerul e plin de fulgi,/ Cerul și pământul una,/ Peste tot e-un mândru giulgiu.// Peste noapte 


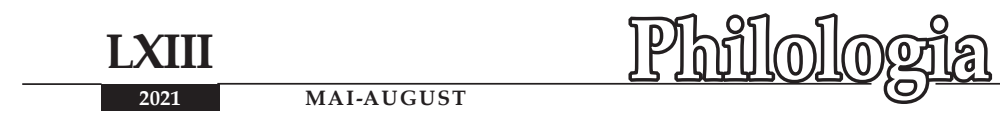

încă ninge,/ Troienind și sat, și drum./ Casele le pot distinge/ Numai după stâlpi de fum.// Firea doarme somn de moarte,/ Tot cuprinsu-i troienit.../ Omule, avea-vei parte/ Și tu azi să dormi tihnit?”.

În secvențe de pastel e surprinsă Valea Răutului: ,Șes întins, fântâni în cale,/ Printre lanuri un drumeag,/ Stuhării colo în vale;/ Peste vale culmi șirag.// Nu se vede unde-i gârla,/ Doar colo un pârăiaș/ Se zărește unde-i târla/ Și s-aude-un fluieraș.// Mai departe apa lină/ Se ascunde-n păpuriș/ Și de-acolo la lumină/ Iese numai pe furiș.// Zarea-i dulce, cenușie./ Aeru-i păinjinit/ De o boare argintie,/ Ce plutește-n val grăbit.// Pe întinsele ogoare/ Muncă sub aprinsul cer;/ Pe urcuş, sclipind la soare/ Pânza drumului de fier...// Cine-ar spune, că alt-dată/ Pe aici s-a scurs puhoi/ De barbari din lumea toată/ Pân a nu veni la noi?// Ne-o spun șirul de movile,/ Ce răsar pe-ntinsul șes/ Carte mută, fără file,/ Dar cu mare înțeles". Orizontul idilic din „Cartea mută, fără file,/ Dar cu mare înțeles” se înscrie în arsenalul imagistic al lumii ca o carte, cu nelipsitele implicații paseiste.

În Altarul străbunilor, discursul e centrat pe aceeași „temă cu variațiuni”: antiteză dintre generații, dintre străbunii ,rumeni, drepți ca niște brazi” și „,vlăstarul lor de azi -/ Slab și mic la-nfățișare”, prezentul deplorabil, ruinat și trecutul, pe exaltarea trecutului în defavoarea prezentului: „Umbre blânde vin tiptil/ Dinspre valea adormită,/ Și cu buze de copil/ Fruntea îmi sărut trudită.// Stau culcat pe prispa casei/ Din străbuni lăsată mie: -/ Toți s-au dus, iar eu rămasei/ Al ruinei strajă vie...// Mă gândesc la vremea veche, -/ Căci cu umbrele-mpreună,/ Să-mi șoptească la ureche/ Vin străbuni de voie bună.// Rumeni, drepți ca niște brazi,/ Ei privesc cu jale mare/ La vlăstarul lor de azi -/ Slab și mic la-nfățișare...// Simt că inima-mi se zbate,/ Când străbunii intră-n casă/ Pe uși joase și-aplecate,/ Din vechime-așa rămasă...// Dar când luna își arată/ Fața rece de aramă,/ Umbrele purced de-odată/ Peste gard și peste cramă.// Și străbunii le urmează,/ Părăsind pe-al lor vlăstar,/ Care pururea veghează/ Ruinatul lor altar”.

Narațiunile poetice, cu substrat autobiografic, abundă în destăinuiri nostalgice, în traditia confruntării prezentului cu trecutul idilic: ,S, S-am poposit în casa veche,/ Unde-am trăit copil în voie/ Cea vrâstă fără de pereche,/ Când nu știi grijă și nevoie.// Și mi-am adus în minte iarăși/ Din cele petrecute-atunci,/ Când hoinăream cu buni tovarăși/ Prin sat, pe dealuri și prin lunci...//Ah, vremuri sfinte de-altădată,/ Departe-n urmă ați rămas! / Pierzându-vă, eu nu o data/ Mă-ntreb: pe unde sunteți azi?// Și mă izbesc cu-a mea gândire/ De-o singură dorință vie:/ Să mă întorc din rătăcire/ La cuibul din copilărie..." (În cuibul copilăriei).

Altă dată, poetul, evocând „veacuri de robie”, „crudă dușmănie” în total dezacord cu „catastiful sămănătorist”, cheamă la „lupta mare” pentru a reinstaura, este adevărat, ,așezăminte bune/ Cum au fost în vremi străbune”: „Moldoveni, stăpâni ai tăriii,/ Bate ceasul învierii/ Pentru visurile sfinte/ Ingropate în morminte.// ...Deci cu toți treziți-vă/ Și ca frați uniți-vă,/ Ca să-ncepem lupta mare/ Pentru cele ce ne doare:// Pentru-așezăminte bune,/ Cum au fost în vremi străbune,/ Pentru drepturi și pământ,/ Că acesta ni-i mai sfânt" (Spre unire).

Unul dintre ,,cântecele de leagăn”, scris în 1915, dar oprit de cenzura rusească, apărut în Viața Basarabiei (1937, nr. 5-6) cu remarca „Din «Caietul uitat», 1913”, pare exemplar pentru o poetică centrată pe vitalism, realism și autenticitate: 
„Dormi, sprâncenatule,

Dormi, neînduratule,

Dormi, cât măicuța te ține la brațe,

Sub chiorăitul flămândelor mațe -

Cântec amarnic de inimă-albastră.

Cântecul foamei, muzica noastră!...

Dormi, obiditule,

Dormi, osânditule,

Dormi, de pe-acum răzvrătitul de foame,

Moise părtaș la „revolte islame”

De răsturnare a ,ordinii sfinte”

$\mathrm{Cu}$ închisori pentru bietu-țí părinte!...

Dormi, țărănaşule,

Dormi, buclucașule,

Dormi, cât al nostru bordei nu e ocnă.

Dormi, cât picioarele mele nu-s bocnă,

Dormi, cât muncesc ca o roabă, cinstită,

Și n-am ajuns de vânzare ca vită!...

Dormi, moldovanule,

Dormi, năzdrăvanule,

Care mă faci să mai cred în scriptură:

Chiar dacă toți mă înșală, mă fură

Și mă lovesc nemilos ca pe-un câine, -

Tu-mi pregătești răzbunarea de mâine!..."

Poemul, reprodus de Halippa în articolul Ceva despre țăranul basarabean (Viața Basarabiei, 1942, nr. 10-11), își află reflexe inedite în însemnările lui Petru Comarnescu Poezii energetice și dinamice scrise la 1907 și 1915, găzduite de Revista Fundațiilor Regale (1943, nr. 3), din care reținem câteva observații privind: „stilul energetic, cu expresii dure și tăioase, obișnuit în ultimii ani în scrisul acelor poeți care cultivă eroicul și preamăresc mai ales țărănismul, vroind să-1 sugereze și prin forma și ritmica poeziilor, a existat cu mult înainte” sau: „La 1907 și $1915 \mathrm{nu}$ este posibil ca poeții Mateevici și Halippa să cunoască modelele străine, în afară poate de unii poeți ruși (...) E în poezia aceasta mult din ritmica, imprecațiile și răzvrătirea liricii unui Whitman, unui Carl Sandburg sau Esenin, geniali instigatori şi profeți în diferite sensuri, dar participând la crearea unui aceluiaşi stil de poezie dinamică și energetică, într-adevăr profetică și cutremurătoare, mai mult prin fondul care depășește și robește forma" (Comarnescu, 1943, p. 709-711).

Modelul poeziei tranzitive domină în lirica socială, în care cantabilitatea și dexteritatea ritmică e schimbată pe versul prozastic, pe limbajul personificat și hiperbolic, intensificând, prin tehnica aglomerării, dimensiunea nenorocirii lumii: 


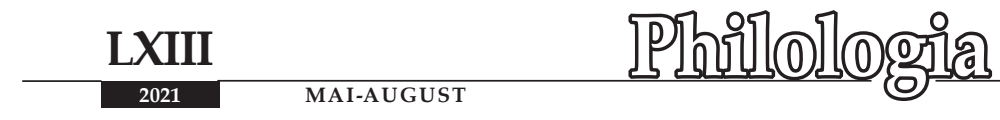

„Te duci în lumea neființei,/ An groaznic și mânjit de sânge,/ An plin de-atâtea suferințe,/ Că-n urma ta cu toți vor plânge.// Călău nebun și crud din fire,/ Te duci, și-n oarba-ți nepăsare/ Nu te gândești ce moștenire/ Lași vremurilor viitoare!// Diata-ți, ce cu sânge-i scrisă,/ Ingheață sângele din vine;/ Și lumea, cu-a ei răni deschise,/ Blestem avea-va pentru tine.// Te-or blestema părinţi și mume,/ Copii rămași fără de tată,/ Soții nenorocite-n lume,/ Ce-și văd nădejdea îngropată.// Te du deci an de vijelie!/ Și las ca-n neagra-ți pomenire/ O pildă veșnică să fie/ Pentru trudita omenire!" (Anului 1914).

Halippa e un împătimit al creației orale (s-a păstrat un caiet al poetului cu culegeri din folclorul autohton). Dragostea pentru țăran și pentru poezia populară se manifestă din primele îndeletniciri literare atât în lirica socială, cât şi în cea erotică. În manieră cvasifolclorică, memorabile sunt compunerile în care se recurge la personificări, la dialoguri cu codrul sau cu bătrânul Nistru: „,- Bună ziua, Nistrule,/ Nistrule, bătrânule!/ Am venit să te mai văd,/ Să tentreb, la sfat să şăd:/ Că tu, frate, multe știi,/ Multe vezi, pe unde vii,/ Multe prinzi și multe-auzi/ Prin huceagul un-te-ascunzi!.../ Ce mai veste ne aduci,/ Pe-ale tale unde dulci,/ De la frații cei din sus/ Și acei de la apus?/ Ce mai știi de viața lor/ Sub jugul străinilor?/ Spune, dragă, de ce taci?/ Oare nu cumva te faci,/ Că n-auzi, Măria Ta,/ Rugămintea caldă-a mea! -/ Însă Nistru parcă-i mut,/ Parcă-i un moșneag tăcut./ Ce-a văzut, 1-a întristat, - / O rușine ș-un păcat:/ Că români-s ferecați/ De hainii împărați.../ Și eu plec, cum am venit, / Amărât, nedumerit,/ Cu nădejdea-mi - praf în vânt, / Cu avântu-n două frânt" (La Nistru). Textul (datat august 1913, Soroca) este un dialog cu poemul Vorbeau azi noapte două ape de Octavian Goga, scris cu prilejul comemorării unui veac de la răpirea Basarabiei: „N-auzi cum strigă Basarabii/ Blestemul zilelor ce vin,/ Cum sună-n bucium pârcălabii/ De la Soroca la Hotin?/ Eu simt cum matca mea tresare? De-al amintirilor șuvoi,/ Arcașii lui Ștefan cel Mare/ Îmi cer azi moaștele-napoi”.

Forma folclorică e activată în lirica socială care, prin oralitatea și simplitatea expresiei, amintește de Cântecul zorilor de Alexei Mateevici: „Plouă, ninge. -/ Hai la drum!/ N-ai când plânge,/ Frate bun!// Drumul vieții/ Este lung:/ Sure cete/ Îl ascund./ Grea e calea/ Și cu chin:/ Multă-i jalea,/ Mult suspin../ Da tu, frate,/ Nu căta/ Peste toate/ Vei călca!/ Cu credință/ Mereu, mereu,/ Biruința-i/ Scopul tău!/ Las' hodina/ Celor morți:/ Fii albină/ Pentru toți./ Odihni-vei/ Trupul tău,/ Când sfârși-vei/ Drumul greu.// De răsplată,/ De-i muri,/ Bunul Tată/ S-a-ngriji!..// Deci de ninge,/ Hai la drum!/ N-ai când plânge,/ Ș-apoi cum?/ Doar ai casă/ Și copii:/ Cer pe masă, -/ Bine-o știi!"' (La drum!).

În poezia ocazională apelează la unitatea tuturor românilor. De regulă, poezia se confundă cu improvizația reductibilă la strigarea bucuriei libertății, exprimată în stereotipia simbolisticii elementare (nou soare, vechea ceață, suflă vânt de primăvară): „Suflă vânt de primăvară,/ Ca nicicând din miază-noapte,/ Și ne-aduce veste-n țară/ Despre scumpa libertate.// Piere groaznica robie,/ Ce de-un veac ne tot apasă;/ Peste-ntreaga-mpărăție/ Un nou soare vrea să iasă.// El alungă vechea ceață/ Și îndeamnă lumea toată/ Să-și rodească-o nouă viață/ Largă, slobodă, bogată.// Obosiți de învrăjbire,/ Toți se trag la acest soare:/ El vestește înfrăţire/ Între tagme 
și popoare...// Să primim deci cu credință/ Vestea ce ne vine, iată!/ Și de vechea umilință/ Să ne scuturăm odată!// Moldoveni, ce-ați fost de-ocară,/ Ridicați și voi privirea:/ Suflă vânt de primăvară,/ Vine, vine primenirea!” (Vestirea libertății).

Sau: „Moldoveni, la joc odată!/ Azi e zi de sărbătoare/ Pentru mic și pentru mare,/ Pentru românimea toată.// Am fost robii tuturora/ Și mereu supuși ocării.../ Azi e ziua neatârnării,/ Deci cu toți să-ncingem hora!" Vocea poetului e concurată de vocea omului politic: „Că de astăzi înainte/ Țara nu va mai fi sclavă;/ îndreptați cu drepturi sfinte..." (Hora neatârnării Basarabiei).

La congresul ostașilor moldoveni (20-28 octombrie 1917), Pan Halippa se adresa către militari cu cuvinte care mai apoi vor fi reluate în versuri: „Sunt nespus de fericit că am ajuns să urez în fața voastră floarea neamului nostru moldovenesc. Frații mei! Veacuri întregi noi am umblat rătăciţi unul de altul, de veacuri întregi pe noi ne întind și ne dezbină vrăjmașii, de veacuri întregi pământul nostru strămoșesc geme sub jugul străin și iată acum, după atâtea răzlețiri, după atâția ani de jale și suferințe, ne-am strâns frații grămăjoară. $\mathrm{O}$, cine va spune bucuria noastră? Grea a fost soarta noastră crudă, lungă a fost noaptea în care am zăcut, dar cum după noapte răsar zorile și lumina zilei ia rândul întunericului, așa și în viața noastră, a neamului moldovenesc, după robie s-a simțit apropierea izbăvirii. Frați ostași! În voi este toată nădejdea noastră. Țara se îneacă în lacrimi şi sânge. Vrăjmașii noștri stau la hotare - vrăjmași câtă frunză și iarbă la spatele nostru și înăuntrul țării noastre, dar cei mai mari dușmani sunt în mijlocul nostru. Aceasta este neunirea! Frații mei, biruiţi acest straşnic duşman și noi vom birui totul". Trăit autentic, evenimentul e transpus într-o poezie a dialogurilor cu miza pe știința ostaşului moldovean, văzut ca o ființă gânditoare și simțitoare: „Ori credeți voi că Rusu-și schimbă/ Năravul de stăpân cu sila?/ E meșter gâdele la limbă,/ Dar sufletu-i nu știe mila.// Ostași, a vorbelor beție/ Lăsați-o celor în smintire:/ Pe voi, la minte-ntregi, vă-mbie/ A voastră țară cu iubire!// Ori n-auziți voi cum vă cheamă/ Părinții voștri dați uitării?/ Ori n-auziți voi glas de mamă,/ Zbucnit din ghearele ocării?// Săriţi cât este încă vreme,/ Surorilor, spre apărare:/ De nu, pe capul vost' blesteme/ Cădea-vor greu doborâtoare!// Veniți să punem stăpânire/ Pe vatra noastră strămoșească!/ Destul străină-oblăduire/ Pe Țara noastră Românească!’ (Către ostașii moldoveni). Este o poezie emblematică pentru starea de spirit în mișcarea de eliberare națională, o poezie angajată în înțelegerea/ exprimarea revoluției în desfășurare.

Poezia sentimentului religios e copleșită de pietate creștină, de suferințe și ,,de rugă fierbinte spre ceruri”: „Din căi rătăcite, Stăpâne,/ La netede drumuri mă scoate,/ Ș-ajută-mă, Sfinte Părinte,/ Să scap de dureri și păcate.// Păzește-mă, Bunule Tată,/ De multele lațuri întinse/ Și vindecă-mi inima slabă/ De pofte și patimi cuprinsă.// Spre neamul meu blând în durere/ Îndreaptă-mi, Stăpâne, privirea,/ Căci n-avem aiurea un sprijin/ Și-n Tine vedem mântuirea.// E timp să se facă dreptate/ Și nouă ce tragem durere!/ Îndură-Te-n ceasul pieirii,/ Căci altfel ni-i peste putere !"’

Ruga este expresia unui suflet identificat cu durerea neamului, o durere ajunsă la starea de paroxism, amestecată cu un sincer și puternic atașament pentru ideea mântuirii, exprimată la modul abstract, indecis; evlavia e răzbită de „,cernita îndoială”: ,Și-mi arde pe buzi rugăciunea,/ Ca mucul luminii în sfeșnic;/ Iar blândul 


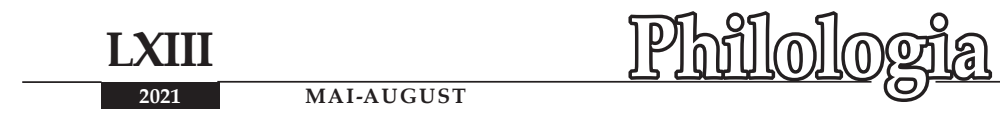

Hristos mă mângâie/ Cu zâmbetu-i dulce și veșnic...// Dar iată că mucul se-ndoaie/ Și sfârâie-n ceara topită,/ Apoi lumânarea se stânge/ În noaptea amarnic cumplită.// Și-n sufletu-mi slab și molatic/ Cernita-ndoială răzbește;/ Iar ruga, fierbintea mea rugă,/ Pe buze încet se sleiește..." (În miez de noapte).

Îndemnul către o autentică trăire a vieții e în Sfat creștin pentru că: „Din toate câte sunt în viață/ Pe-acest pământ rotund sub soare/ Stăpâni suntem abia pe-o ceață/ De clipe grabnic trecătoare”. Gânduri cernite îi adăpostesc ființa în năzuința că: „Deșertăciune-s, dragă, toate/ Și praf din drum suflat de vânt” $(P e$ o filă de psaltire). În figura lui Isus de pe crucea Golgotei îl surprinde revelația înfrățirii în suferință: „O, fraților în suferință,/ Răbdați și inimile sus?/ Căci noi avem în umilință/ Ca-ntâi tovarăş pe Isus" (Isus pe cruce). Isus, ca întâi tovarăș în umilință, devine simbolul deșteptării: „Azi se nașe Adevărul:/ Oameni, deșteptați-vă!/ Ca lumina Lui din ceruri/ Luminați-vă! (De Crăciun).

La 1917 învierea lui Hristos nu este concepută altfel decât prin deșteptarea „tagmei de jos”, prin înfăptuirea unirii: „Din clopotnița din sat/ Sună clopotele, sună,/ Vestind lumii veste bună,/ Că Hristos a înviat.// Cele mici în cor duios/ Sună des cu voioșie,/ Că e zi de veselie/ Pentru tagma cea de jos.// Iar cel mare, cam dogit,/ Sună rar, sună agale,/ Că s-a dus vremea de jale/ Șl că răul s-a sfârșit...// Sunați, clopote, sunați/ Și vestiți la lumea toată,/ Că robia e sfărmată/ Și că toți de-acuma-s frați!// Și mai spuneți tuturor,/ Că sunt vremile unirii/ Și că-i timpul primenirii/ Stărilor bătrânilor” (Clopotele invierii). „Timpul primenirii" e binecuvântat de Hristos, prevestind o nouă epocă, o nouă ordine în haosul barbar.

Lirica de dragoste se remarcă prin simplitate și sinceritate, prin ritualul așteptării/ împlinirii erotice, prin ceremonia comportamentului jucăuș, la care iau parte elementele arhetipale: fântâna, stelele, luna, mierla: „Sus pe cerul plin de stele/ Luna-ncet călătorește,/ Nourași în horboțele/ $\mathrm{Cu}$ argint îi poleiește.// Mierla cântecu-și îngână,/ Pe când eu în așteptare,/ De ghizdele, la fântână,/ Răzimat stau în picioare.// Stau ș-aştept pe puica mea,/ După apă ca să vie.../ Apă, zău, că n-ași prea vrea,/ De-un sărut mi-i sete mie...// Căci arsura dorului/ Nu se stinge cu băutul/ Din apa izvorului, -/ Ci se stinge cu sărutul...// Ah, și setea-mi crește-ntr-una,/ Pe când puica zăbovește,/ Iar în cer, vrăjită, luna/ Spreasfințit se tot grăbește...// Vino, puică, te îndură/ De-a mea patimă nebună./ De-a mea strașnică arsură,/ De-al meu dor născut pe lună" (Cântec).

Invocarea sentimentului erotic e de un patetism și de o naivitate debordantă: „Vino, dragoste nebună,/ Vagabondă prin natură,/ Și-n grozava ta furtună/ Îmi aruncă-a mea făptură...// Mult, prea mult am fost cuminte;/ N-am fugit numai o dată/ De-ale tale dulci cuvinte,/ Când mi le-a rostit vreo fată.// Astăzi însă las chilia/ Vieții mele solitare,/ Vino, adă-mi bucuria:/ Șoaptele de alintare!..." (Chemare). Versificatorul nu este lipsit de fantezie inventivă în definirea dragostei în Amor, Scrisoare, Altă scrisoare sau în texte ca acesta: „Copilă dragă, nu te-ncrede-n vorba lui,/ Căci nestatornic ca poetul nimeni nui.// De dragoste cuprins puternic într-o Luni,/ El Marți era să fie pus printre nebuni.// Ca Miercuri dragostea iubitei să-și declare,/ Iar Joi să fie ziua grea de așteptare.// Și cum nici Vineri nu primise un răspuns,/ De Sâmbătă un gând de 
moarte 1-a pătruns.// Dar când veni Duminică, un dor de viață/ Îi șterse de pe fruntea lui a morții ceață” (Din albumul unei domnișoare).

Uneori poetul-luptător se resimte un învins: „Am cântat și eu odată,/ Astăzi nu mai cânt;/ Am luptat din greu și iată:/ Sunt răpus, înfrânt!// Dar în suflet n-am tristeță/ Și căință n-am:/ Închinat-am tinereță/ Țintei ce urmam.// Resemnat în dor și gânduri,/ Nu-s pentru bucluc:/ Alte vremuri, alte cânturi, -/ Eu, cel vechi, mă duc!// Vie alții să-mi ia iocul -/ Și cu rod bogat!/ Viața să le dea norocul,/ Ce nu mi 1-a dat!” (Resemnare) sau: „Azi sufletu-mi, în lupta grea învins,/ Petrece-n jale-amară și suspine" (Sonet).

Alteori se vede un inadaptat, un dezrădăcinat: „Cândva și eu o țarăaveam!/ Ca-n paradis/ În codri cu poieni trăiam.../ Dar a fost vis! ...// Viată-n plin duceam noi doi,/ Și de ne-nvins/ Părea iubirea între noi.../ Dar ea s-a stins!// Azi vagabond, mereu la drum,/ Într-un abis/ Aș vrea să cad, să mă fac scrum.../ Ce jalnic vis!..." (Amărăciune).

Formați în școli rusești, Alexei Mateevici, Pantelimon Halippa sau Ion Buzdugan, literații grupați în jurul revistei Cuvânt moldovenesc reprezintă etapa de trecere a scrisului de aici „de la Basarabia rusească la Basarabia românească" (Onisifor Ghibu). Nu încape îndoială că Pan Halippa pare un poet minor, anacronic, un „scriitor nerealizat” (M. Cimpoi), chiar și cu cele două volume de poezii Cântare omului și Pământul nădejdilor mele, conținutul cărora îl putem intui lejer. Ne o demonstrează cu prisosință cele 280 de poezii publicate pe parcursul vieții sale. A eșuat și tentativa de a edita un manuscris după eliberarea din gulag și închisori. Din perspectiva zilei de azi, poezia lui, în pofida lipsei de originalitate artistică, a figurației poetice precare, rămâne, cu siguranță, foarte importantă ca ,document uman”.

Versurile de până la Marea Unire atât cele incluse în Flori de pârloagă, cât și acele din „caietele uitate”, majoritatea apărute pe paginile revistei Viața Basarabiei (1932-1944), prezintă un mare interes cultural. Sunt lăudabile și traducerile din poeții ruși. Se rețin traducerile care exprimă stări de spirit, idei nestrăine creației sale. Remarcabile sunt Nu cânta de A. Pușkin, Iahtul de M. Lermontov, Cântec de leagăn de A. Fet, Cântece populare rusești ș.a. Unele texte, nu numai de publicistică literară, apărute în Cuvânt moldovenesc, Foaia plugarilor, Calendarul Basarabiei, Viața Basarabiei, cu conținut didactic sau social-politic, surprind prin actualitatea lor.

\section{Referințe bibliografice:}

CĂLINESCU, George. Istoria literaturii române de la origini până în prezent. Ediția a II-a, revăzută şi adăugată. București, 1986.

CARDAȘ, Gheorghe. Prefață În: Poeții şi prozatorii Basarabiei până la Unire (1812-1918). București, 1937.

CIOBANU, Ștefan. Cultura românească în Basarabia sub stăpânirea rusă. Chișinău, 1993. 
COMARNESCU, Petru. Poezii energetice și dinamice scrise la 1907 şi 1905. În: Revista Fundațiilor Regale, 1943, nr. 3.

IORGA, Nicolae. Calendarul ligii culturale pe anul 1909. Vălenii de Munte, 1908.

IORGA, Nicolae. Istoria literaturii românești contemporane. București, 1985.

LOVINESCU, Eugen. Istoria literaturii române contemporane. 1900-1937. București, 1989.

SADOVEANU, Mihail. Prefață În: Pan. Halippa Flori de pârloagă (1912-1920). Iaşi, 1921.

Notă: Articolul a fost realizat în cadrul proiectului de cercetare 20.80009.1606.03 Contexte socioculturale autohtone şi interconexiuni europene în creaţia populară şi literatura cultă din Basarabia (sec. XIX până în prezent), Institutul de Filologie Română „B. P.-Hasdeu” al MECC. 


\title{
PARADOXURILE TRANZIȚIEI. PERSONAJELE LUI DAN LUNGU, IULIAN CIOCAN ȘI DUMITRU CRUDU ÎNTRE NOSTALGIE ȘI SCHIMBARE
}

\author{
Galina ANIȚOI \\ Doctor în filologie, conferențiar cercetător \\ E-mail: galina.anitoi@gmail.com \\ ORCID: https://orcid.org/0000-0002-3166-1472 \\ Institutul de Filologie Romană „Bogdan Petriceicu-Hasdeu” (Chișinău)

\section{Paradoxes of Transition. Dan Lungu, Iulian Ciocan and Dumitru Crudu's Characters between Nostalgia and Change}

\begin{abstract}
One of the transition paradoxes from totalitarianism to democracy is nostalgia for the communist past that persists in society and 30 years after the fall of the totalitarian regime. This phenomenon represents, according to the specialists in the field, the expression of the revolt against the socio-political and economic transformations of the transition. Nostalgia becomes a place of refuge for those who do not find themselves in today's society.

In the present work there will be analyzed the novels „Heaven of the Hens” and „I am a communist woman!” by Dan Lungu, „Slaughter in Georgia” and „People from Chisinau” by Dumitru Crudu, „Sasha Kozak's Land” by Iulian Ciocan which configure literary typology of the nostalgic character after communism.

Keywords: transition, paradox, postcommunism, Romanian literature, character, nostalgia, change.

\section{Rezumat}

Unul din paradoxurile tranziției de la totalitarism la democrație îl constituie nostalgia după trecutul comunist, care persistă în societate și la 30 de ani după căderea regimului totalitar. Acest fenomen reprezintă, potrivit specialiștilor în domeniu, expresia revoltei împotriva transformărilor social-politice și economice ale tranziției. Nostalgia devine un loc de refugiu pentru acei care nu se regăsesc în societatea prezentului.

În articolul de față vor fi analizate romanele „Raiul găinilor” și „Sunt o babă comunistă” de Dan Lungu, „Măcel în Georgia” și „Oameni din Chișinău” de Dumitru Crudu, „Tărâmul lui Sașa Kozak” de Iulian Ciocan, care configurează tipologia literară a personajului nostalgic după comunism.

Cuvinte-cheie: tranziție, paradox, postcomunism, literatura română, personaj, nostalgie, schimbare.
\end{abstract}


În literatura de specialitate fenomenul social-politic al tranziției postcomuniste este abordat în strânsă legătură cu dilema continuitate - discontinuitate. „Continuitatea constă în moştenirea regimului comunist, a mentalităţii formate în condiţiile societăţii totalitariste, dar şi a patrimoniului tradiţional, în general, iar discontinuitatea se referă la efortul deliberat de reorganizare a vechiului sistem de valorificare a experienţei sale" (Capcelea, 2012, p. 112).

Această dilemă a generat, susțin cercetătorii tranziției (cf. Capcelea, 2012, p. 135-142; Saca, Tataru, 2016, p. 77-78), mai multe paradoxuri în ceea ce privește mentalitatea și comportamentul actorilor sociali în perioada de tranziție a societății de la un regim totalitar la democrație, paradoxuri care „pe parcurs (...) s-au modificat căpătând noi nuanțe" (Saca, Tătaru, 2016, p. 78). Unul din ele ar fi „fantoma comunismului” care bântuie încă societățile postcomuniste și la 30 de ani după căderea regimurilor totalitare comuniste (cf. Anton, 2020, p. 6) sau, altfel spus, coexistența - în cazul României, dar mai cu seamă al Republicii Moldova, unde tranziția pare a fi interminabilă (acestea constituind arealul nostru de cercetare) - a unor ,elemente incompatibile, democratice și totalitare” (Saca, Tataru, 2016, p. 77).

La începuturile sale, tranzitiia postcomunistă promitea reforme sociale radicale, transformări benefice majore în toate sferele vieții, a căror finalitate era, în sens larg, libertatea și prosperitatea tuturor, precum și instaurarea valorilor și principiilor democrației. Realitatea însă a fost departe de așteptările și entuziasmul marii majorități a populației care aspira la o îmbunătătire rapidă a nivelului de trai, unul ,asemănător cu cel din Occident” (Cerna, 2014), tranziția dovedindu-se a fi „dificilă și plină de capcane” (Anton, 2020, p. 7).

Reformele întârziate, tergiversate sau stagnate, prăbușirea industriei, liberalizarea pieței, politicul defectuos au atras după sine pierderea locurilor de muncă, inflația, sărăcia, șomajul, inechitatea economică, proliferarea corupției etc. Transformările înnoitoare s-au lăsat cu multe „costuri sociale” și efecte negative (chiar dacă pe termen scurt), generând în sânul societății o stare de incertitudine și neîncredere în valorile democrației. În aceste condiții, o mare parte dintre oameni (,victime ale tranziției”), mai inertă și lipsită de capacitatea de adaptare, nu s-a putut regăsi în noua societate. În consecință, aceștia au început să se raporteze cu multă nostalgie la timpurile de odinioară, la trecutul comunist, pe care îl asociau cu stabilitatea, siguranța, bunăstarea, existența fericită, fară griji, contrapunându-1 tranzitiei confuze.

E necesar să menționăm că fenomenul nostalgiei comuniste a devenit subiect de interes pentru specialiști din mai multe domenii: sociologie, istorie, antropologie, politologie, filozofie etc. Ceea ce, aproape unanim, consemnează/ constată multitudinea de studii consacrate acestui fenomen e faptul că referințele la perioada comunistă nu vizează componenta ideologică și nu se nasc din dorul după ordinea politică de altădată. Acest tip de nostalgie reprezintă, cum bine observă Mioara Anton, „expresia dezamăgirilor prezentului” (ibidem, p. 7) aflat în tranziție spre beneficiile capitaliste, a unei revolte împotriva noului și necunoscutului, a unui „,mecanism de apărare în fața ritmurilor accelerate ale schimbărilor și răsturnărilor istoriei" (Boym, 2001, p. XV). 
Problematica tranziției și, legat de aceasta, paradoxul nostalgiei comuniste au pătruns și în ficțiunea literară.

În rândurile ce urmează ne vom referi la romanele Raiul găinilor și Sunt o babă comunistă! de Dan Lungu, Măcel în Georgia și Oameni din Chişinău de Dumitru Crudu, Tărâmul lui Sașa Kozak de Iulian Ciocan, care configurează tipologia literară a personajului nostalgic după comunism. Scriitorii își recrutează prototipurile din mediul obişnuit: pensionari dezamăgiți, muncitori ajunși șomeri, tineri debusolați etc., care ilustrează/ întruchipează mentalități și comportamente ale unei societăți în plină primenire și redefinire.

În Raiul găinilor (2004), roman care „presupune, pe lângă plăcere estetică, reflecție" (Matei, 2007, p. 201), Dan Lungu ne oferă cea mai sugestivă metaforă a tranziției: un „tunel”, unul „luuung de ți se acrește” (Lungu, 2007, p. 85), vorba personajului Mitu. Nu există aici un protagonist, în centrul atenției se află personajul colectiv - comunitatea mică, mahalaua, mai exact locuitorii de pe Strada Salcâmilor.

Aparent insignifiante, lipsindu-le o structură complexă, aceste personaje de la periferia unui oraș, neantrenate în nici o activitate, își trăiesc existența anostă povestind istorii de viață, proprii sau ale altora, sau rememorându-și trecutul comunist, oftând, o parte din ele, că ,înainte era mai bine”. Din poveștile și comportamentul lor deducem că acest ,înainte era mai bine” transpune melancolia comunității după vremurile de până la tranziție, deși în roman identificăm și o altă perspectivă asupra comunismului. Relu Covalciuc, bunăoară, este vocea celor care suspină că „nimic nu mai este ca înainte!” (ibidem, p. 113), acest „,ca înainte” fiind expresia perioadei de până la 1989, când toți aveau un loc de muncă și ,se putea fura în voie tot felul de materiale" (ibidem, p. 109) care prindeau bine în gospodărie: „Doar gardurile, confecționate din sârmă scoasă din fabrică, drese cu scânduri sau pătrate de tablă și zugrăvite cu vopsea din proprietatea statului, doar aleile dintre dependințe, construite cu bolțari și cărămizi furate din gară, ori șoproanele și magaziile, acoperite cu carton și smoală sustrase din întreprindere, le mai aminteau de vechiul loc de muncă. Și pensia «de să te caci în ea», îi dădu dreptate, în gând, lui Titi Burduja, fostul său coleg de serviciu" (ibidem, p. 112).

În drum spre „Tractorul șifonat”, crâșma străzii, unde bărbații se adună ca într-o „mică-mare familie” (Vakulovski, 2007, p. 205), Relu Covalciuc răscolește amintirile din anii comunismului despre viața percepută de el (și mulți alții ca el) frumoasă şi îndestulată: „Nimic nu mai era ca înainte, constată pentru sine Relu Covalciuc, scuturându-și din nou o pietricică din șlapi. E-he, pe vremuri dom'Petrică era pictor. (...) Statul îi răsplătea talentul și munca. Cu banii câștigați o ducea destul de bine. Chiar dacă în magazin nu era cine știe ce marfă, găseai să cumperi în altă parte. Totul era să fii harnic, să cauți. Acum intri în magazin, te zgâiești la galantare și la rafturile ticsite, înghiți în sec și te întorci acasă. (...) Înainte nu se găsea nimic, dar congelatoarele erau pline. Trebuia să te descurci. Toată lumea se descurca! (...) Dom'Petrică era ditamai pictorul! (...) Era cineva! Era pictor la Î.L.F., Întreprinderea de Legume și Fructe! Acum? (...) Ce se întâmplă acum cu talentul lui dom'Petrică? Exact ce se întâmplă cu sute și sute de maiștri, pricepuți și specializați, care stau pe prispă acasă sau pe vreun butuc de salcâm la un Ticu Zidaru" (Lungu, 2007, p. 113). 


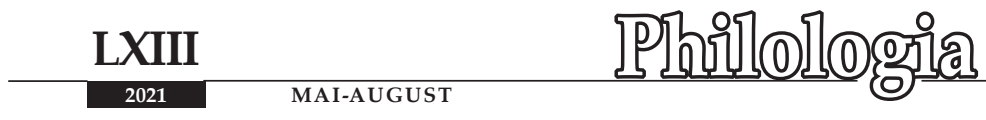

O altă voce care se aude mereu în incinta „Tractorului șifonat” e cea a lui nea Mitu. Acesta spune bancuri despre Ceaușescu, dar și alte povești de viață, din care desprindem atât o ușoară nostalgie după vechea orânduire, cât și atitudinea sa față de realitatea de după revoluția din 1989. Despre viaţa în comunism nea Mitu relatează cu mult haz, fapt ce ne dă temei să credem că acest personaj care, deși nu e încântat de tranziție, considerându-se ,pârlitul tranziției” (ibidem, p. 77), ,calicul tranziției” (ibidem, p. 79), „fraier al tranziției” (ibidem, p. 81), realizează, fie și într-o mică măsură, că „,pe timpul lui Ceașcă” (Ceaușescu - n.n.), chiar dacă avea ,mai mult mălai” (ibidem, p. 77), „, ceva parale” (ibidem, p. 79), ,ca sculer-matrițer te mai învârteai de-un bacșiş" (ibidem, p. 88), nu mai trăia Partidul Comunist exclusiv cu grija poporului, căci și membrii de partid ,erau oameni, le ghiorăiau și lor mațele de foame, aveau și ei copii la facultate. Furau (...) pe ruptelea, că doar aveau de unde" (ibidem, p. 29-39).

Există și alte voci în roman care susțin că bunăstarea de altădată a fost una înșelătoare. Disputele pe tema dacă pe vremea comuniștilor s-a trăit mai bine sau mai rău vorbesc de la sine: „«Și ce, bă, era rău când erau comuniștii?» «Ba era bine, cum nu? Mie și-acu' mi-i dor de-o coadă la carne, de să n-am butelie să-mi fac un ceai.» «Degeaba spui, de foame nu s-a murit.» «Io zic că mai degrabă de sete nu s-a murit. Că era rachiu pe toate drumurile, să-1 iei cu polonicu'.» «Iar când intrai în serviciu, îți dădea casă... Acu' ce-ți dă? Un rahat îți dă.» "Ce să zic, că dădea din buzunarul lui...» «Chiar așa, nu tot noi ăștia cu palmele crăpate le făceam?» (...) «Și ce, era rău?» «Da' la tine-n casă n-ai văruit tot din cauza lui Ceaușescu? Ții doliu după el? (...) Dacă înainte se văruia, nu-nseamnă, frate, că era mai bine, asta vreau să zic. (...) poate eu n-aveam chef să văruiesc. (...) Nu puteai! Vrând-nevrând, hai la văruit, tovarăși! (...) Și dacă nu mergeai cu tovarășii la văruit... Atâta îți trebuia. Erai huligan, legionar, poponar, aveai tu ceva.» «Așa le trebuie puturoșilor! Chiar mai rău!» «Mâncare n-avem, tovarăși, dar, hai, luați bidineaua și dați un var, să fie frumos, c-așa-i în comunism, totul trebuie să fie ca nou când vine șefu'. Și punem și-un pic de muzică, să nu se-audă mațele ghiorăind»" (ibidem, p. 174-175).

Personajul colectiv din Raiul găinilor îl reprezintă foștii meseriași care au ținut pe umerii lor industria țării și care s-au pomenit acum, în prezentul tranziției spre o viață mai bună, aruncați la periferie. Existența lor insipidă, aparent fără rost, se consumă în întâlnirile zilnice ale bărbaților la crâșma „Tractorul șifonat” (unde se bea mult, se povestesc bancuri despre Ceaușescu, se ironizează, se rememorează viața din perioada comunistă), în vizionarea telenovelelor, în comentarea zvonurilor, întâmplărilor etc., disimulând, de fapt, drama ființei umane ,atrofiată chiar în esența ei” (Diaconu, 2007, p. 202). Este drama celor profund marcați de „tarele totalitarismului" (ibidem, p. 202), povară de care nu mai pot scăpa. Din cauza unui soi de inerție în gândire, conduită, manifestări etc. care se hrănește din refrenul ,înainte era mai bine”, această umanitate se dovedește incapabilă, neputincioasă în a-și căuta și găsi reperele în noua realitate provocată de schimbarea regimurilor.

Tema nostalgiei paradoxale după comunism este reluată cu mai multă pregnanță în romanul Sunt o babă comunistă! (2007), fapt pe care autorul însuși îl declară întrun interviu: totul ,a pornit de la sesizarea unui paradox care m-a intrigat: cum se 
poate ca mulți, chiar foarte mulți oameni care au trăit într-un regim totalitar, inuman, fără sa se fi bucurat de privilegii și favoruri, acum să fie capabili de nostalgii? Prin intermediul unei bătrâne, care, la persoana întâi, își relatează propria viață, încerc să demontez mecanismele nostalgiei și să dezleg enigma psihologică" (Crețu, 2007). Titlul romanului este o replică a personajului principal, Emilia (Mica) Apostoae, pensionară, care și-a trăit o bună parte din viață în anii comunismului românesc. Ea întruchipează prototipul omului „,care regretă din rărunchi comunismul” (ibidem) și a cărui nostalgie după vechea orânduire e de o îndărătnicie greu de înțeles și acceptat. Ca și Relu Covalciuc (dar și alte personaje din Raiul găinilor) a cărui „filosofie” de viață din tranziție se sprijină pe convingerea că ,înainte era mai bine”, și Emilia Apostoae își idealizează trecutul, considerând că a trăit mult mai bine în vechiul sistem decât acum: „Doamne, ce bine am dus-o pe timpul comunismului!” (Lungu, 2010, p. 85).

Discuția la telefon cu fiica ei, Alice, stabilită în Canada, despre viitoarele alegeri și opțiunile lor electorale îi developează atașamentul pentru valorile unui timp revolut și îi pune în evidență condiția de nostalgică incorigibilă după fostul regim:

„-- Ia spune-mi, mamă, cu cine votezi duminică? Și de asta te-am sunat.

- De asta nu dormiți voi în Canada? Că nu știți cu cine votez eu?

- Nu e încă o problemă de interes internațional (...), dar eu aș vrea să știu... Ia zi!

- Dar tu votezi?

- Sigur, la ambasadă... Ia zi!

- Ă-hă-hăăă, până duminică mai e o grămadă... am timp să mă gândesc și să mă răzgândesc de o sută de ori...

- Ufff, mă duci cu vorba. Stai să-ți explic. Eu aici fac parte dintr-o asociație românească... și ne-am propus să facem și noi ceva pentru alegerile din România... așa că fiecare trebuie să-i vorbească unei persoane, două, trei, câte cunoaște, și să le convingă să voteze pentru democrație...

- Adică faceți campanie electorală, nu?

- Păi, nu chiar... Ideea e nu să voteze cu cutare sau cutare partid, ci să nu voteze cu foștii comuniști.

- Daaa? Dar atunci cu cine să voteze, cu Papa Pius?

- Hai, mamă, eu vorbesc serios...

- Dar ce, eu glumesc? Pentru mine, lucrurile sunt simple: înainte de revoluție o duceam muuult mai bine decât acum. (...)

- Cred că exagerezi cu «mult mai bine», mamă. Îți amintești ce cozi erau la carne? Făceau înconjurul blocului...

- E drept, erau cozi pe atunci, dar acum intri în magazin, admiri cotletele, înghiți în sec și ieși frumușel afară, că nu ai cu ce le cumpăra. Eventual te uiți la un proaspăt îmbogățit cum ia două kile de mușchi. Nu știu, zău, când era mai bine... Acum am văzut la televizor oameni care mor de foame, familii cu copii care dorm în stradă... Pe vremea comunismului nu se întâmpla asta.

- O să se regleze și astea... Deocamdată suntem în tranziție... (...) Dar libertatea, mamă? Asta nu se compară cu nimic. Atunci ne era frică și de umbra 


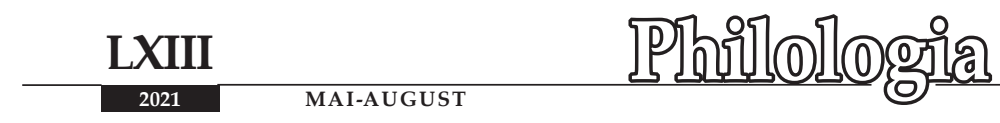

noastră... Faptul că acum poți să spui ce vrei și să scrii ce vrei, să călătorești și să strigi «Jos guvernul!»...

- Știi ce, călătoresc tot îmbogățiții, cei care au furat ce-am muncit noi. Cât de strigat, acum strigi până nu mai poți, că oricum nu te ascultă nimeni... Dacă ar fi după mine, eu și mâine aș vrea să se întoarcă comunismul.

- Vai, mamă, eu ziceam că te faci, dar tu ești mai comunistă decât credeam!

- Uite că mi-am dat arama pe față. Sunt o babă comunistă, dacă nu știai. Asta sunt." (ibidem, p. 61-63).

Lucrurile nu se consumă odată cu încheierea discuției. Dimpotrivă, această convorbire telefonică, în urma căreia Emilia Apostoae conștientizează incompatibilitatea de viziune și de simțire între ea și fiica sa, îi declanșează amintirile despre existența, din punctul ei de vedere, frumoasă şi îndestulată, pe care a dus-o în anii de glorie ai comunismului, generând, totodată, și conflictul interior al personajului. Femeia, fostă muncitoare la o fabrică de construcții metalice, își rememorează viața din perspectiva beneficiilor de care a avut parte atunci: „În primul și în primul rând, pe mine comunismul m-a făcut orășeancă. (...) Dacă nu se făceau fabrici, drumuri, apartamente... dar fabrici în special... noi două, Emilia și Alice, la ora asta călcam tizic de ne ieșeau ochii, undeva într-un sat ascuns între gloduri. (...) După un loc de muncă, comunismul mi-a dat apartament și butelie... Gratis, reține" (ibidem, p. 63-64).

Drama personajului vine din faptul că nu se poate adapta acestui prezent postdecembrist, care propune cu totul alte valori și convingeri decât cele pe care le împărtășește ea. Își construiește propriul univers, compus din amintiri, care îi oferă sentimentul de siguranță și pe care îl opune realităţii sociale în care trăiește și cu care este în dezacord. Mai mult, în naivitatea ei de nostalgică, îi trece prin minte ideea de a reface ceva din trecut, de a redeschide atelierul de confecții metalice, dar nu este susținută nici de sora sa, Sanda, nici de foștii ei colegi. Drama femeii se amplifică atunci când constată atitudinea negativă a celor din anturajul ei față de regimul de altădată, când realizează că nimeni nu mai rezonează cu ,ideea raiului comunist”: „Cum să fie prost un sistem în care eu am dus-o bine?” (ibidem, p. 209).

$\mathrm{Cu}$ toate că disputa cu Alice, istoria de viață a doamnei Rozalia - care, spre deosebire de ea, a avut de suferit de pe urma regimului totalitar - și discuțiile cu fostele ei colege o deconcertează, făcând-o să trăiască și (scurte) momente de îndoială și reflecție, „baba comunistă” rămâne neclintită în nostalgia și „,credința în perfecțiunea acelor vremuri după care tânjea" (Nica, 2013, p. 95), devenind, la nivel de personaj literar, ,vocea colectivă a tuturor nostalgicilor” (Anton, 2020, p. 16).

Dincolo de faptul că personajele lui Dan Lungu întrunesc caracteristici ale unei tipologii umane cu mentalitate și comportament „,comuniste”, acestea sunt simpatice și memorabile. Savoarea lor vine din umorul, hazul și maniera specifică prin care le prezintă autorul.

În cazul prozatorilor basarabeni, vom remarca tușele grotești care predomină în modalitatea de reprezentare a nostalgicilor.

Situația își găsește explicarea în contextul social-politic specific al Republicii Moldova, în care ,pe unul dintre primele planuri în perioada tranziției s-au impus 
atât problemele democratizării, cât și cele ale identității naționale" (V. Saca, 2001, p. 43). Pe lângă dificultățile impuse de tranziție (sărăcie, corupție, șomaj, migrație etc.), societatea basarabeană e nevoită să înfrunte și divergențele nesfârșite dintre comuniști și democrați. Căci în Republica Moldova - spațiul (ex-sovietic) în care ai impresia că mersul lucrurilor s-a oprit în loc, în care trăiești sentimentul de „încremenire în tranziție” -, la trei decenii de la căderea regimului totalitar, Partidul Comunist există pe bune, reunind indivizi conservatori, refractari la tot ce înseamnă înnoire, modernizare și valori democratice, europene. $\mathrm{Cu}$ ascendențe în „homo sovieticus", o mare parte a pro-comuniștilor din Basarabia o constituie nostalgicii după URSS. Această realitate contradictorie, paradoxală este foarte bine surprinsă în prozele lui Dumitru Crudu și Iulian Ciocan.

Măcel în Georgia (2008) este romanul care aduce în prim-planul narațiunii atmosfera încinsă, tensionată a anilor ' 90 (din Georgia și din R. Moldova). E perioada care marchează sfârșitul Uniunii Sovietice, nu și a „,răului imens pe care 1-a făcut popoarelor pe care le-a stăpânit" (Alexe, 2012, p. 125), așa cum bine observă Maria Alexe, căci „mentalitățile au supraviețuit” (ibidem). URSS-ul dispare, dar nu toți se bucură de acest fapt.

Dacă personajele lui Dan Lungu regretă comunismul lui Ceaușescu, cele ale lui Dumitru Crudu deplâng comunismul sovietic. Este important să subliniem faptul că nucleul narațiunilor lui Crudu îl constituie dilemele identitare și conflictele interetnice din spațiul tranziţiei basarabene, unde disensiunile dintre indivizi/ grupări cu viziuni diametral opuse continuă decenii la rând. Oricât ar părea de paradoxal și absurd, există persoane care idolatrizează defunctul imperiu. Nedumerirea eroului principal, care a scăpat ca prin minune de o bătaie cruntă din cauză că a arborat tricolorul deasupra discotecii din satul de baștină, sporește pe măsură ce realizează că cei care iubeau pătimaș un sistem dictatorial care i-a privat de libertate și drepturi sunt chiar semenii săi, cei cu care a copilărit: ,(...) îi știam pe fiecare în parte. $\mathrm{Cu}$ toții erau fii de țărani, o duceau greu, nici unul dintre ei nu avea blugi, adidași sau o geantă cu curea, nici unul nu avea schiuri sau magnetofon și eu îi priveam încurcat și nu înțelegeam de ce acești adolescenți de 16 ani sau acești flăcăi de 21 sau 22 de ani iubesc Uniunea Sovietică, odată ce Uniunea Sovietică nu le-a dat aproape nimic în această viață. Dar ei o iubeau. O iubeau cu patimă. O iubeau aproape ca pe o femeie. O iubeau fără a se gândi de ce o iubesc și fără a face vreo legătură între părinții lor, care smulgeau de dimineață până seara târziu frunze de tutun pe câmpiile accidentate din jurul satului. (...) Dar tinerii, care se zborșeau la mine, nu vedeau nici o legătură între faptul că încă din clasa întâi căraseră și ei în spate grămezi de frunze de tutun și acest drapel roșu care flutura deasupra cozorocului ușii. Ei iubeau la nebunie tot ceea ce ținea de Uniunea Sovietică, cu toate că părinții lor nu ajunseseră mai departe de Ungheni; nici măcar Chișinăul sau Bălțiul nu îl văzuseră, nu văzuseră nici o singură țară străină; nu fuseseră niciodată la mare sau într-o stațiune; nu știau cum arată o salată de crabi și nu mâncaseră niciodată măsline. Ei iubeau patria sovietică" (Crudu, 2008, p. 146-147).

Există în roman încă un personaj care se înscrie perfect în galeria literară a nostalgicilor după comunism: Nadejda Filipovna Ostroumnaia. Situată în proximitatea Emiliei Apostoae, „baba comunistă” a lui Dan Lungu, prin 


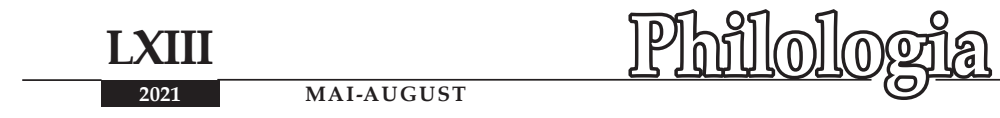

obstinația cu care susține și apără comunismul sovietic, Nadejda Filipovna, această bătrână „fleșcăită”, speră că sovieticii se vor întoarce. Mai mult chiar, fiind convinsă că se vor întoarce, ea urcă pe vârful unui munte cu un steag roșu în geantă: „Da, Nadejda Filipovna mergea pe brânci. Cu cât suișul era mai greu, cu atât mai mare era îndârjirea Nadejdei Filipovna de-a se vedea urcată pe cel mai înalt pisc și când, în cele din urmă, a pus piciorul ei zaharisit pe creasta muntelui, am observat că satisfacția Nadejdei Filipovna nu mai avea margini: se simțea învingătoare; câștigase pariul cu muntele îndărătnic. (...) a scos din tașcă medaliile tovarășului Ostroumnâi și le-a agățat de reverul bluzei ei decoltate. Tot din geantă a scos și chipiul de militar al soțului ei, pe care 1-a afundat pe cap. (...), după care a pornit-o spre crângul revenos din apropiere, examinând cu multă migală crengile copacilor, iar după ce a ales un ram lung, subțire și drept, a scos bărdița din tașcă. L-a tăiat și 1-a strujit cu mare grijă și s-a reîntors în punctul cel mai înalt al piscului. A deschis din nou geanta, a scos un ac, o ață și o flamură roșie, pe care a înfășurat-o în jurul bățului și a cusut-o. Apoi a ridicat steagul deasupra capului, nu înainte însă de a-l pupa îndelung și cui poftă. Era drapelul Uniunii Sovietice, pe care erau imprimate chipul lui Lenin și stema țării sovietelor, secera și ciocanul. Bătrâna aia dichisită și fleșcăită îl înălța, cu semeție, spre cer. Îl agita nervoasă deasupra capului ei grizonant, făcând cercuri tot mai largi pe piscul prăpăstios. Nadejda Filipovna alerga fericită, cu drapelul Uniunii Sovietice deasupra capului, pe creștetul chel și posomorât al muntelui" (ibidem, p. 332-333).

Același atașament irațional, ,patologic” față de tot ce înseamnă comunism și comuniști îl manifestă și bătrâna rusoaică Valentina Pavlovna, unul dintre personajele romanului Oameni din Chişinău (2011), roman al cărui „,centru de greutate" îl constituie „febra socială generată de evenimentele din 7 aprilie 2009" (Corcinschi, 2013, p. 42). „Hoașca” trecută de șaptezeci de ani ajunge în piața din fața Guvernului, unde aveau loc protestele împotriva fraudării alegerilor și, pitită după un copac, spiona pe cei care scandau împotriva președintelui comunist pe care ea îl adora. Sentimentul de ură pe care-l trăiește în raport cu protestatarii care mărșăluiesc împotriva președintelui atinge cote paroxistice: „,...) știam ce boală avea pe oamenii care răcneau contra președintelui pe care ea atât de mult îl iubea. Îi detesta cu o forță egală celei cu care îl admira pe președinte. Treaba asta i se citea pe față. Era de-a dreptul stacojie, de parcă se pregătea să se arunce asupra mulțimii adunate în piață. Nici măcar nu încerca să-și ascundă mânia care o cuprinsese, fiind gata să-i frece oricui ridichea sub nas sau să-și scoată cuțitul din teacă” (Crudu, 2011, p. 64).

Și pensionarul Oleg Olegovici Liulin din romanul Tărâmul lui Sașa Kozak (2011) al lui Iulian Ciocan e un nostalgic după timpurile comunismului sovietic. Afectat de nepăsarea oamenilor care ignorau tomberonul și aruncau gunoiul în mijlocul curții - semn al „hidoșeniei” tranziției interminabile -, acesta „regreta dispariția Uniunii Sovietice, a țării în care era ordine" (Ciocan, p. 2011, p. 7), însă conștientiza faptul că e neputincios în fața timpurilor noi. Nu-i rămâne decât să se resemneze cu cotidianul sordid al tranziției, așa cum s-a întâmplat cu mulți alții ca el. 
Concluzii. Nostalgicii lui Dan Lungu, Dumitru Crudu, Iulian Ciocan indică asupra remanențelor unei mentalități afectate de un sistem totalitar, în fond fals și alienant. Aceste personaje sunt întruchiparea unei umanități „viciate” de comunism, care, simțindu-se lipsită de protecția unei entități statale, s-a rătăcit în nebuloasa tranziției.

\section{Referințe bibliografice:}

ALEXE, Maria. Ineditul prozei postmoderne în Balcani. Timișoara: Brumar, 2012.

ANTON, Mioara. Comunismul în postcomunism. Nostalgii și nostalgici. În: Polis. 2020, nr. 3, p. 5-33.

BOYM, Svetlana. The Future of Nostalgia. New York: Basic Books, 2001.

CAPCELEA, Valeriu. Tranziția moldovenească: fazele, elementele structurale, dimensiunile, paradoxurile, eșecurile și avatarurile ei. Chișinău: Arc, 2012.

CERNA, Silviu. Un sfert de veac de tranzitie. În: Economistul, nr. 49-50, 15 decembrie 2014 [online]. Disponibil: file:///C:/Users/Admin/AppData/Local/Temp/ UNSFERTDEVEAC.pdf [citat 13.05.2021]

CIOCAN, Iulian. Tărâmul lui Sașa Kozak. București: Tracus Arte, 2011. 2013.

CORCINSCHI, Nina. Soarele și păunul. Chișinău: S. C. Profesional Service SRL,

CREȚU, Bogdan. Ascensiunea și declinul omului nou. În: Observator cultural, nr. 363, 15.03.2007 [online]. Disponibil: https://www.observatorcultural.ro/articol/ ascensiunea-si-declinul-omului-nou-2/ [citat 15.05.2021]

CRUDU, Dumitru. Măcel în Georgia. Iași: Polirom, 2008.

CRUDU, Dumitru. Oameni din Chișinău. Iași: Polirom, 2011.

DIACONU, Mircea A. Referințe critice. În: Lungu, Dan. Raiul găinilor: fals roman de zvonuri și mistere. Iași: Polirom, 2007.

LUNGU, Dan. Raiul găinilor: fals roman de zvonuri și mistere. Iași: Polirom, 2007.

MATEI, Alexandru. Referințe critice. În: Lungu, Dan. Raiul găinilor: fals roman de zvonuri și mistere. Iași: Polirom, 2007.

NICA, Marius. Personaje feminine și melancolia comunistă în romanele lui Dan Lungu. În: The Proceedings of the EUROPEAN INTEGRATION-BETWEEN TRADITION AND MODERNITY Congress. Târgu-Mureș: Editura Universităţii „Petru Maior”, 2013. Volume Number 5, p. 89-96. [online]. Disponibil: http://old.upm.ro/facultati_departamente/ stiinte_litere/conferinte/situl_integrare_europeana/Lucrari5/IETM5_Part12.pdf [citat 22.05.2021]

SACA, Victor. Interese politice și relații politice: dimensiuni tranzitorii. Chișinău: CE USM, 2001.

SACA, Victor, TATARU, Valeriu. Impactul mentalității asupra calității democrației în societățile de tranziție a Federației Ruse, Ucrainei și Republicii Moldova. În: Revista de Filozofie, Sociologie și Științe Politice, 2016, nr. 3, p. 65-80.

VAKULOVSKI, Mihai. Referințe critice. În: Lungu, Dan. Raiul găinilor: fals roman de zvonuri și mistere. Iași: Polirom, 2007.

Notă: Articolul a fost realizat în cadrul proiectului de cercetare 20.80009.1606.03 Contexte socioculturale autohtone şi interconexiuni europene în creaţia populară şi literatura cultă din Basarabia (sec. XIX până în prezent), Institutul de Filologie Română „B. P.-Hasdeu” al MECC. 


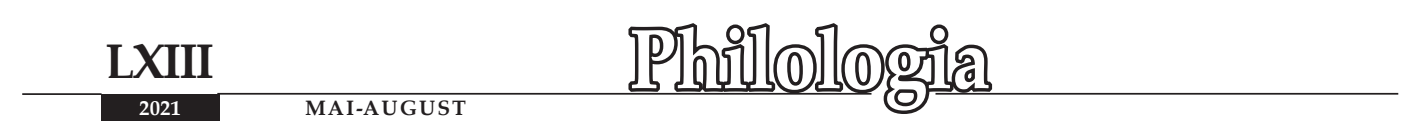

https://doi.org/10.52505/1857-4300.2021.2(314).05

CZU: 821.135.1.09+004.55

\title{
POVESTEA „IVAN TURBINCĂ” DE ION CREANGĂ ŞI NOUL EXPERIMENT HIPERTEXTUAL \\ OXANA GHERMAN
}

\author{
Doctor în filologie \\ E-mail: oxana.gherman@yahoo.com \\ ORCID: https://orcid.org/0000-0001-7366-2599 \\ Institutul de Filologie Română „Bogdan Petriceicu-Hasdeu” (Chișinău)

\section{The Story „Ivan Turbincă” by Ion Creangă and the New Hypertextual Experiment}

\begin{abstract}
The article presents the results of the research of hypertextual relationship between the story Ivan Turbinca (Iasi, 1878) by Ion Creanga and Ivan Turbinca 2.0. A Continuation of the Story by Ion Creangă (Iasi, 2019) by Alexandru Vakulovski. Having the status of hypertext, the 2019 version of the story is created through the process of transposing the fabulous world in another spatio-temporal framework, in a cross-cultural virtuality. The mechanism that generates the image of the new artistic world is based on the process of symbolic transfiguration of the essence of ethnic history. The author studies the process of codifying the national history in the system of symbols of the hypetext and the dialogical relations between the voices. identity.

Keywords: hypertextuality, dialogue, artistic world, fabulous, sociopolitical,

\section{Rezumat}

Articolul expune rezultatele cercetării raportului hipertextual dintre povestea Ivan Turbincă (Iași, 1878) de Ion Creangă și Ivan Turbincă 2.0. O continuare a poveștii lui Ion Creangă (Iași, 2019) de Alexandru Vakulovski. Având statut de hipertext, varianta din 2019 a poveștii este creată prin procedeul transpoziției lumii fabuloase într-un alt cadru spațio-temporal, într-o virtualitate transculturală. Mecanismul care generează imaginea noii lumi artistice are la bază procesul de transfigurare simbolică a esenței destinului etnic. Autoarea studiază procesul de codificare a istoriei naționale în sistemul de simboluri al poveștii, dar și raporturile dialogale dintre vocile hipoși hipertextului.
\end{abstract} identitate.

Cuvinte-cheie: hipertextualitate, dialog, lume artistică, fabulos, sociopolitic,

Raportarea contemporaneității la tradiția și la moștenirea literară este un aspect care a intrat zgomotos în sfera cercetărilor în postmodernism și, mai cu seamă, în 
momentul când, prin viziunile genettiene asupra fenomenului transtextualității, au putut fi conceptualizate multiple forme de relaționare între literaturile diferitelor epoci și/ sau spații culturale. Au fost stabilite câteva modalităţi noi de creaţie artistică care presupun proliferarea literaturii prin transfigurarea textelor clasicizate (imitație, pastișă, parodie, travesti ș.a.). În acest mod, s-a putut constata că, odată cu textele care continuă, prin transformări succesive, o tradiție, înaintând în siajul unor fenomene literare de durată, dar și cu apariția, la răspântia epocilor, a unor creații de tranziție sau de inovație, se desfășoară și un proces de recuperare a valorilor trecutului, de repunere în circuit a operelor canonizate.

Este binecunoscut faptul că lucrările care marchează o epocă sau un gen, care constituie matricea estetică a unei literaturi, devin, în timp, resorturile ei interioare și sunt periodic regenerate prin diverse posibilități de (re-/ inter-/ meta-/ hiper-)textualizare, ceea ce le redescoperă. Între acestea, fenomenul hipertextualitătii presupune cele mai sofisticate procedee creative. În concepția teoreticianului francez Gerard Genette, hipertextualitatea reprezintă ,relația dintre în text B (pe care îl vom numi hipertext) cu un text anterior A (hipotext), pe care îl grefează într-un mod diferit de cel al comentariului” (Genette, 1982, p. 7-19). Cercetătoarea Lucia Țurcanu explică ,înțelesul genettian de derivare a unui text din altul, prin imitație sau transformare, în regim satiric sau grav" și enumeră strategic varietăţile hipertextualităţii: ,imitația ludică (pastişa), satirică (şarja) şi serioasă (forjeria); transformarea ludică (parodia), satirică (travestirea burlescă) şi serioasă (transpoziția)" (Țurcanu, 1999, p. 26). Textul derivat printr-o procedură de hipertextualizare are un statut descensiv și constituie ceea ce G. Genette numește literatură de grad secund. În studiul oricărui text de gradul doi, ne interesează câteva aspecte de ordin tehnic: procesul prin care se creează cea de-a doua lume artistică prin extinderea/ transformarea dimensiunilor primei, raporturile dialogale dintre instanțele intra- și extratextuale (vocile textului-sursă și cele ale textuluiderivat), „granițele” convenționale care delimitează lumea hipertextului de cea a hipotextului ș.a.

Experimentul hipertextual este o modalitate de creație care se practică în proza contemporană. Un exemplu ilustrativ ar fi, bunăoară, evoluția în calitate de resursă de creație a poveștilor lui Ion Creangă. La un secol și jumătate de la apariție, scrierile crengiene adoptă statutul de hipotexte pentru noi povești, scrise de prozatorii zilelor noastre. Proiectul editorial Creangă 2.0 din cadrul Festivalului Internațional de Literatură și Traducere (FILIT) 2019 include o colecție de cinci volume semnate de câțiva scriitori români care au creat continuările unor povești de Ion Creangă: Capra cu trei iezi 2.0 de Matei Vișniec, Prostia omenească 2.0 de Bogdan Alexandru Stănescu, Harap Alb 2.0 de Veronica D. Niculescu, Punguța cu doi bani 2.0 de Lavinia Braniște și Ivan Turbincă 2.0 de Alexandru Vakulovski. Astfel, operele au fost readuse la zi, transfigurate, revalorizate și extinse pe anumite dimensiuni ale imaginarului fabulos. Fiecare hipertext presupune o formă de raportare a posterității la creația crengiană, dar și o dovadă a deschiderii prozatorilor postmoderni față de experimentul artistic. Angajate într-un inedit proces creativ, poveștile devin texte-sursă, texte-origine.

Ivan Turbincă 2.0. O continuare a poveștii lui Ion Creangă (Iași, 2019) de Alexandru Vakulovski, este creată prin transpoziția unei lumi fabuloase în contextul actualității. Autorul păstrează codul și convenția hipotextului, dar modifică 


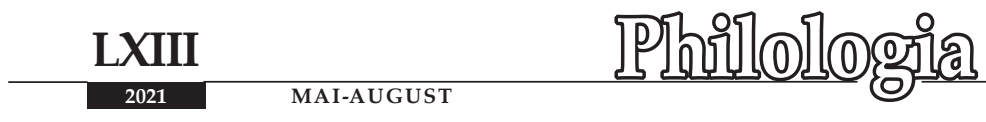

structura imaginarului spațio-temporal, transformându-1 într-un sistem semnificant. Fără a trăda, la nivelul discursului, dificultățile ce țin de constrângerile convenției, se creează o voce narativă supraindividuală, omniprezentă și omniscientă, care transgresează spații și timpuri, prezentând, cât se poate de organic, lumea interioară a protagonistului în raport cu realitățile în care trăiește. Instanța narativă (cu statut demiurgic) se încadrează firesc în lumea reprezentată de hipertext, iar discursul rămâne în albia stilului crengian, chiar dacă absoarbe (prin cuvinte-cheie și simboluri) limbajele anumitor epoci istorice. Narațiunea menține cititorul în mreaja fabulosului, dar, în același timp, întreține și conexiunile dialogice între ficțiune și realitate, or, povestea codifică câteva momente din istoria basarabenilor.

Hipertextul Ivan Turbincă 2.0 continuă linia de subiect a poveștii crengiene: personajul este imaginat în alt cadru spațio-temporal, unde interacționează cu alte tipuri umane și trăiește noi aventuri fabuloase, nu fără legătură cu realitatea. După ce năstrușnicul Ivan (la sfârșitul poveștii lui Creangă) își câștigă - ca pe o pedeapsă - nemurirea, pornește în explorarea altor spații întru împlinirea scopului vieții lui („tabacioc, votchi și femei”) și se confruntă, inevitabil, cu problema de pretutindeni: nefericita întâlnire cu forțele malefice. Dacă la Creangă interferența diavolilor în ordinea lumii se limitează la niște competiții de agerime, jocuri haioase sau vicleșuguri care strică relațiile sau confortul oamenilor, atunci, în varianta hipertextualizată aceasta produce o adevărată debandadă socială, maleficul fiind ilustrat drept primă cauză a degradării umanului.

În povestea lui Alexandru Vakulovski, centrul de atenție se mută ușor dinspre acțiunea personajului spre spiritul locului. Unul dintre mecanismele prin care se generează imaginea lumii fabuloase presupune procesul de transfigurare simbolică a specificului sociopolitic și istoric al spatiului pe care îl explorează Ivan. Incipitul presupune o combinație ludico-simbolică pe cât de antrenantă, pe atât de sugestivă: „A fost odată ca niciodată, că de n-ar fi, nu s-ar povesti, o țară mică-mică în care s-a trezit închis Ivan Turbincă. De fapt, nici măcar nu era țară, ci o bucată de țară. Sau, mai bine zis, o bucățică dintr-o bucată. Și această țară era comparată ba cu o palmă, ba cu un strugure, dar adevărul e, cum i se părea lui Ivan Turbincă, că semăna mai mult cu turbinca lui de pe vremuri, în care dacă intra ceva, apoi ieșea mai greu. De-a lungul vremii oamenii acestei fâșii de pământ dintre două râuri se culcau seara într-o împărătie și se trezeau dimineața în altă împărăție, fără să iasă din sat." (Vakulovski, 2019, p. 1). Incipitul nu lasă vreo îndoială în ceea ce privește semnificația sistemului de simboluri care exprimă esența echivalentului real al acestui tărâm al minunilor, în care se pomenește Ivan Turbincă.

Hipertexul dezvoltă o fabulă dinamică, progresivă, aventura personajului evoluează din spațiul etnic într-o virtualitate transculturală, păstrând ,„pânza de interconexiuni" (A. Grati) cu hipotextul. Liantele între textul-origine și hipertext sunt atât aluziile, reluările rezumative ale unor momente-cheie din hipotext, cât și transformarea instanței auctoriale a acestuia în personaj fabulos. Uriașul roșcat, pe care Ivan Turbincă îl întâlnește pe ciudatul tărâm, nu-i decât întruchiparea lui Ion Creangă. Jocul creativ prin care autorul poveștii originare devine personaj în povestea derivată este un element care asigură buna funcționare a întregului mecanism de transpozitie a realitătii în dimensiunea fabulosului. Pe de altă parte, acest truc tehnic conferă spațiului românesc (transfigurat în lume fabuloasă) o imagine unitară, or, personajul migrează fără impedimente dintr-o parte în alta. 
Printre altele, rescrierea creativă, cu implicații și aluzii sociopolitice, a poveștii Ivan Turbincă nu este de absolută noutate. În anii '60, în literatura din Basarabia, apare nuvela cinematografică „Se caută un paznic” de Vlad Ioviţă (rev. „Nistru”, 1966, nr. 1), pelicula fiind interzisă în 1970, din cauza conținutului subversiv: „în povestea lui Creangă, Ivan Turbincă păzește raiul de rele, de cei păcătoși; în textul lui Ioviţă, dimpotrivă, lumea e ,pe dos”, pentru că se caută un paznic care să oprească evadarea din rai a sfinţilor (a se citi din raiul comunist)" (Băicean, 2015, p. 8). Lucrarea lui Vlad Ioviță țintește „fenomenul evadării din rai”, transfigurare cu vădite corespondențe în realitatea timpurilor.

Imaginarul hipertextului creat de Alexandru Vakulovski scoate în evidență alte câteva probleme de ordin sociopolitic, cum ar fi cea a identității etnice sau cea a granițelor absurde dintre două bucăți ale aceluiași întreg geografic: „Fără să se grăbească, printre rațe și gâște, Ivan Turbincă a ajuns și la marea apă, a traversat-o înot, că oricum nu se putea îneca. Deși trecut prin multe, nu și-a dat seama despre ce fel de apă e vorba. Una care separă, care foarte rar te primește în ea cum l-a primit pe Ivan. Mai des ea e păzită de pe ambele maluri, iar oamenii sunt ciuruiți de soldați care își pescuiesc frații cu gloanțe de plumb" (Vakulovski, 2019, p. 3). Descrierea cu aluzii a spațiului „dintre ape" încifrează istoria reală a locului unde Dumnezeu are „vocea înfundată” pentru că „,dracii cu ochii tulburi de drojdie se cătărau pe biserici, rupeau crucile, dădeau foc la icoane" (ibidem, p. 6). Mai multe secvențe reprezentative ale istoriei etnice a basarabenilor sunt absorbite în narațiune.

Problema identității este reflectată și prin observațiile lui Ivan asupra tiparului comportamental al unor categorii de personaje pe care le întâlnește în spațiul numit și „cușcă”: oameni „cu ochii tulburi” (semnificând viziunea opacă asupra realității a oamenilor angrenați în sistem), care „se poartă de parcă n-ar ști de ei" (cu o identitate deformată sub presiunea ideologiei). In lumea acestora, Ivan, fiind dotat cu o conștiință limpede, își dă seama de situația locului numit „,palma dintre ape", de oamenii supuși mutilării și de originea factorului perturbator, a „forțelor drojdiei”: „Lui Ivan i se părea curios că cei mai mulți oameni cu ochii tulburi îi vorbeau în limba lui. Dar nu se lăsa amăgit, nu erau de-ai lui." (ibidem). Personajul află despre câteva dintre consecințele unor experimente diabolice, de pildă, cum înnebuniseră oamenii după „foametea groaznică în care Scaraoschi bagă lumea", și înțelege prea bine și cum s-a întâmplat că, dintre oamenii locului, „cei care au putut observa asta erau închiși în beciuri, băgați în trenuri și duși departe în robie, să înghete, să nu poată vedea mai departe de ziua de mâine" (ibidem). Din moment ce face distinctia între oamenii locului și forțele diabolice care iau chipuri umane și duc în derivă această mică lume „dintre ape”, Ivan se înrolează într-o acerbă luptă contra răului.

Dealtfel, în poveștile crengiene din categoria celor cu motive religioase (Dănilă Prepeleac, Povestea lui Stan Pătitul și Ivan Turbincă), cercetătorii observă că iadul își schimbă treptat localizarea - de la întunericul subteran la suprafață: „,Spre deosebire de iadul din celelalte două poveşti... (Dănilă Prepeleac, Povestea lui Stan Păţitul-n.a.), iadul din povestea Ivan Turbincă nu mai reprezintă spaţiul subteran, ci, asemenea legendelor despre rai, acesta se situează undeva la suprafaţa pământului, aşa că Ivan, după cum ne spune şi povestitorul, îl găsește fără prea mult efort: „nemailungind vorba, îndată porneşte la iad. Şi el știe pe unde cotigeşte, că nu umblă tocmai mult şi numai iaca ce dă şi de poarta iadului" (Creangă, 2013, p. 251). Dacă în 
povestea Dănilă Prepeleac şi în Povestea lui Stan Păţitul iadul era un spaţiu în care se cobora, în povestea Ivan Turbincă ,la iad” se ajunge. Iadul, în unele reprezentări mitice, este spaţiul deschis, în sensul că este predispus să primească pe orişicine, iar în povestea dată, acesta are porţi, adică elementul separator..." (Ivanov, 2017, p. 83-84). Imaginea iadului de pe pământ se conturează mult mai pregnant în povestea lui A. Vakulovski, unde nu mai există „granițe” sau ,porți” între comunitatea umană și cea diabolică, or, acestea se suprapun într-un spațiu al mutațiilor și mutanților, în care diavolii iau chip uman, iar unii oameni se demonizează.

Autorul îl plasează pe Ivan Turbincă în ipostaza unui om simplu, dintr-un sat care este, ca și țara din care face parte, înconjurat de ape. Satul e o parte care reprezintă în mod fidel întregul. Astfel, eroul trece prin tot felul de experiențe în acele vremuri „tulburi”: este pus la muncă forțată, se angajează paznic la o brigadă de tractoare ,în satul înconjurat de iazuri”, unde oamenii beau cât pot, fură cât pot, unora li se tulbură definitiv ochii, iar altora, care devin ,ușor chiori și surzi”, li se luminează ochii când mai fac, cu ajutorul lui Ivan, unele năzdrăvănii ca să-și protejeze lucrurile sfinte. Istoria locală, cea a satului ,înconjurat de iazuri”, aflat sub dominația împărăției dracilor, este o reprezentare în mic a „spațiului dintre râuri”.

Dacă iadul subteran și cel de pe pământ, din cele trei povești ce formează categoria celor cu motive religioase, este un spațiu al deliciilor, al marilor plăceri, inaccesibile pe pământ și, cu atât mai mult, în rai; e un iad pe care Ivan îl caută și la care dorește să obțină acces cu tot dinadinsul; atunci iadul din povestea Ivan Turbincă 2.0 este unul în care se întâmplă să intre fără să-și dea bine seama, e un spațiu atroce, al turpitudinii, al degenerării umanului. Ivan ỉnventează un ,detector de draci” și alte unelte de „corectură” a oamenilor demonizați, execută strategic tot felul de acte de exorcizare, în care folosește boțuri de mămăligă fiartă cu aghiasmă pe post de bombe și grăunțe sfințite în loc de ghiulele. Această luptă comică și tragică în același timp, de esență carnavalescă, care începe în povestea originarắ, este dezvoltată cu o uimitoare dexteritate și imaginație în hipertext. Ivan își găsește si un partener - ,un învătător de pe aceeași stradă” cu brigada unde lucrează. Învățătorul are un scop nobil: să scape satul de draci și de conducerea diabolică. Acești doi eroi fac echipă bună în lupta cu răul, până când, Învățătorul, muritor fiind, se trece din viață și-l lasă pe Ivan singur în slujba binelui.

Aventura lui Ivan continuă până în secolul nostru, când eroul, traversând diverse granițe spațio-temporale, călătorește în camioane, petrece prin crâșme, pe la concerte rock (unde confundă artiștii cu dracii și îi atacă), mănâncă burgeri și privește TV-ul (care arată doar „mirări inutile”). Spre finalul poveștii, Ivan Turbincă se alătură fraților Winchester în lupta cu spiritele malefice. Cu această ocazie, autorul folosește câteva autoreferințe ingenioase: când se prezintă fraților Winchester, Ivan le oferă povestea lui Ion Creangă drept CV, făcând aluzie și la variantele ei ecranizate (alte produse hipertextuale). Pe lângă referințe, aluzii, reluări rezumative, în sistemul de interconexiuni al textului derivat cu textul originar intră și raportul discursului cu produsele noii culturi virtuale (serialul american „Supernatural”, în care personajele centrale vânează demoni). Finalul poveștii lui Alexandru Vakulovski ilustrează creația unui text literar prin hibridizare, la interferența prozei cu cinematografia fantasy. Aceste aspecte transformă textul într-o ficțiune interactivă și antrenantă nu doar pentru cititorii zilei de astăzi, ci și pentru cei ai viitorului. Încheierea poveștii 
pune în centrul atenției o problemă de ordin spiritual, metafizic, ontologic, în măsură să rezolve multe alte dileme de orice tip și nivel: obosit să mai lupte contra diavolilor, Ivan Turbincă se gândește, în ultimă instanță, că e timpul să pornească în căutarea lui Dumnezeu. Finalul, este, așadar, un mesaj adresat lumii actuale.

Functionalitatea hipertextualității, a raportului între hipo- și hipertext, este asigurată de consecvența pe care o păstrează textul derivat în câteva aspecte de bază: păstrarea tiparului interior al personajului central și conturarea esenței lui prin alte mișcări comportamentale, continuarea faptelor lui în lupta cu răul, menținerea convenției textului originar - a dimensiunilor fabuloase ale lumii artistice. Partea inovativă a hipertextului ține de codificarea istoriei naționale în sistemul de simboluri al poveștii, dar și de deplasarea eroului din fantasticul atemporal (transgresând câteva epoci succesive) în contextul actualității sociale, fără a disipa atmosfera de basm.

$\mathrm{Nu}$ poate fi trecută cu vederea natura hibridă a discursului narativ. Este remarcabil, în primul rând, faptul că în țesătura hipertextului se interferează câteva limbaje care aparțin unor instanțe diferite: limbajul naratorului crengian, ancorat (parcă) în epoca în care a trăit autorul, care valorifică oralitatea, regionalul, expresivitatea paremiologică, a cărui discurs este preluat de o altă voce în hipertext, care exprimă o viziune cu totul diferită asupra ficțiunii basmului, dar și asupra lumii. Citit în continuarea poveștii lui Creangă, textul lui Alexandru Vakulovski realizează trecerea insesizabilă de la un discurs la altul, însă vocile narative nu se „contopesc”, ci rămân autonome, distincte. Mai mult, acestea sunt interconectate dialogic. Pentru a anula discrepanța dintre limbajele aflate la un secol și jumătate distanță, autorul textului derivat face uz de elemente specifice/ memorabile din vocabularul personajului crengian, cuvinte și formule pe care i le-a atribuit primul autor („Pașol, Vidma, na turbincu!”; „a ciomăgi”, ,a slobozi”, „hărmălaie”), folosește expresii paremiologice (,fugeau crăpând pământul”; ,s-a dus pe apa sâmbetei”) și forme ale vorbirii orale (,tăt”, „,măligă”, ,popușoi”, ,ciocleji”). Însă, treptat, sunt introduse și unități lexicale care trimit la unele perioade sociopolitice reale, concrete (,brigadă”, „carnet de partid”), iar spre sfârșitul aventurii apar câteva neologisme și expresii din sfera actualității (,camion”, „,televizor”, ,,supermarket”, „, laptop”, ,hamburger”, „rock”, ,agenți FBI”; „a i se tăia maioneza”), discursul rămânând la fel de nuanțat și expresiv. Putem vorbi, în acest context, de o particularitate a textului polifonic, pe care M. Bahtin o numește heteroglosie: hipertextul pune în conexiune dialogică nu doar două voci narative și două categorii diferite de personaje, ci și limbajele diferitor epoci și culturi. Hipertextul, produs prin hibridizare, presupune amestecul câtorva limbaje sociale în același enunț, bivocitatea fiind un fenomen care funcționează pe mai multe niveluri, pornind de la identitatea personajului central, de la numele hibrid Ivan Turbincă, până la finalul lucrării, care contrapune viziunea generațiilor actuale asupra lumii (suspendarea valorilor biblice) unei alte viziuni (căutarea/ regăsirea elementului sacral). Are loc interferența, în același discurs, a cel puțin două „conștiințe lingvistice” din diferite epoci sau spații sociale. Memorabilă, în acest sens, fiind bivocitatea formulei ,glume proaste" în următorul context: ,... Învățătorul chiar îi dădea sfaturi bune, că nu degeaba avea ore la seral, ca să mai facă o carboavă, unde trebuia să studieze Biblia, ca să râdă de ea cu tractoriștii care voiau să termine 7 clase. Tot râzând, învățătorul și-a dat seama că râde degeaba, că, mai degrabă, ar fi de plâns și că glumele proaste pe care trebuia să le predea 


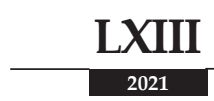

MAI-AUGUST

erau croite tot de Tălpoi” (Vakulovski, 2019, p. 13-14). În semantica expresiei „glume proaste" sunt contrapuse două percepții asupra elementelor sacrale: cea a conștiinței tulbure a celor deformați ideologic, care critică vehement Biblia și râd de credință ca de o naivitate, ca de o tendință obscură, nejustificată, absurdă a oamenilor, dar și cea a conștiinței care, în condițiile întunecatelor timpuri, își păstrează luciditatea, înțelegând că atitudinea represívă față de credință/ religie nu este altceva decât o ,glumă proastă”. Sunt două poziții ideologice opuse pe care vocea narativă le expune, reclamând astfel punctul de vedere al celui care citește. Naratorul are, în acest sens, funcția de operator intertextual; în discursul său sunt încorporate și interconectate discursuri, viziuni, percepții străine, prin intermediul cărora vocea autorului empiric se adresează cititorului real.

Așadar, fenomenul hipertextualizării, ilustrat de povestea Ivan Turbincă 2.0. O continuare a poveștii lui Ion Creangă de Alexandru Vakulovski, reprezintă una dintre căile de evoluție procesuală a literaturii române prin extinderea domeniilor primordiale ale imaginarului fantastic. Ficțiunea poveștii crengiene renaște într-o altă ficțiune, care reflectă nu doar o lume fabuloasă de esență maniheistă, ci și esenta unui destin etnic. Are loc transpoziţia unui sistem semnificant (arhitectura lumii artistice, rețeaua de personaje, sistemul de simboluri etc.) în dimensiunile altuia, articulat în același mod, însă cu elemente de conținut inovatoare, care poate fi receptat în mod optim prin conectare la datele referențiale. Subtextualizarea planurilor istoric, etnic, identitar, sociopolitic printr-un sistem de semne și simboluri apropie textul poveștii crengiene de convenția postmodernistă în care se încadrează hipertextul, o aventură ficțională expusă într-un discurs stratificat, cu nenumărate deschideri dialogice.

\section{Referințe bibliografice:}

BĂICEAN, Iraida. „Lumea pe dos” şi paznicul subversiv (Vlad Ioviţă în dialog intertextual cu Ion Creangă). În: Philologia, 2015, nr. 1-2, p. 8-14.

CREANGĂ, Ion. Amintiri din copilărie. Povești. Povestiri. București: Humanitas, 2013, p. 244-263.

GENETTE, Gérard. Palimpseste. La littérature au second degré. Paris: Seuil, 1982.

IVANOV, Constantin. Spaţiile damnate şi semnificaţia lor în Povestea lui Stan Păţitul şi în povestea Ivan Turbincă de Ion Creangă. În: Revistă de știinţe socioumane, 2017, nr. 3 (37), p. 76-86.

ȚURCANU, Lucia. Ultima epifanie. Chișinău: Arc, 1999.

VAKULOVSKI, Alexandru. Ivan Turbincă 2.0. O continuare a poveștii lui Ion Creangă. Iaşi: Editura Muzeelor Literare, 2019.

Notă: Articolul a fost realizat în cadrul proiectului de cercetare 20.80009.1606.03 Contexte socioculturale autohtone şi interconexiuni europene în creaţia populară şi literatura cultă din Basarabia (sec. XIX până în prezent), Institutul de Filologie Română „B. P.-Hasdeu” al MECC. 
https://doi.org/10.52505/1857-4300.2021.2(314).06

CZU:821.135.1-3(478).09"XX"

\title{
RECEPTAREA PROZEI DIN REPUBLICA MOLDOVA ÎN UCRAINA ÎN A DOUA JUMĂTATE A SECOLULUI AL XX-LEA
}

\author{
DuMitru APETRI \\ Doctor în filologie, conferențiar cercetător \\ E-mail:dm_apetri@yahoo.com \\ ORCID: https://orcid.org/0000-0003-4374-2154 \\ Institutul de Filologie Română „Bogdan Petriceicu-Hasdeu” (Chișinău)

\section{The Reception of Prose from the Republic of Moldova in Ukraine in the Second Half of the 20th Century}

\begin{abstract}
The process of receiving Romanian prose from the Republic of Moldova to Ukraine through artistic translations, carried out between 1954-1989, is treated, in general, under two aspects: the selection and individuality of translators. It is found that, in most cases, there were selected and published not only valuable works but also some writings that lack vigor and authenticity, composed in the spirit of socialist realism. The vast majority of the promoters of Romanian prose in the Ukrainian area represent distinct literary personalities. In the event of continuing the Romanian-Ukrainian literary dialogue, the author suggests selection for translation of other substantial epic works created in the Romanian area east of the Prut until 1940 without ignoring northern Bukovina and Herta. In this regard, the author proposes a list of epic creations that have enjoyed appreciation both in the local literary context and beyond. Only by taking these recommendations into account will the Ukrainian reader be given the true picture of the epic genre in these areas.
\end{abstract}

Keywords: translation, reception, dialogue, selection, process, collaboration.

\section{Rezumat}

Procesul de receptare a prozei românești din Republica Moldova în Ucraina prin mijlocirea traducerilor artistice, efectuate între anii 1954-1989, este tratat, în linii mari, sub două aspecte: selecția și individualitatea traducătorilor. Se constată că, în majoritatea cazurilor, au fost selectate și editate opere valoroase, dar și câteva scrieri lipsite de vigoare și autenticitate, alcătuite în spiritul realismului socialist. Majoritatea covârșitoare a promotorilor prozei româneşti în spațiul ucrainean reprezintă personalități literare distincte. În eventualitatea continuării dialogului literar româno-ucrainean, autorul propune să se selecteze pentru traducere și opere epice substanțiale create în spațiul românesc de la est de Prut până la 1940 și să nu fie ignorat nordul Bucovinei și ținutul Herța. În acest scop, se propune o listă de creații epice care s-au bucurat de aprecieri în contextul literar autohton și nu numai. Doar luându-se în seamă aceste recomandări, cititorului ucrainean i se va oferi imaginea veridică a genului epic din zonele respective.

Cuvinte-cheie: traducere, receptare, dialog, selecție, proces, conlucrare. 


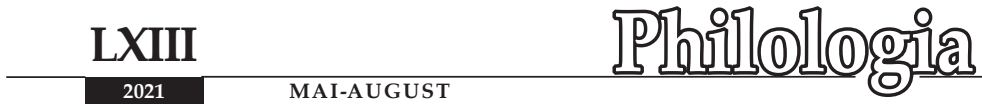

În 1940 Moldova de la est de Prut (Basarabia) a fost alipită la Uniunea Sovietică, stat în care se afla şi Ucraina. Pentru a asigura conviețuirea și funcționalitatea imperiului hrăpăreț pe teritoriile ocupate, Kremlinul promova ideea prieteniei între popoare, ce presupunea, printre alte actiuni, o conlucrare a domeniilor spirituale. În consecință, a fost lansată lozinca „Prietenia popoarelor prietenia literaturilor". Ce-i drept, întrucât literatura rusă și cea ucraineană se bucurau de un statut privilegiat, fiind considerate superioare celorlalte domenii literare naţionale din imperiu, dialogul literelor, și nu numai acesta, nu se desfășura ca între entități spirituale egale. Mai exact, literaturile nominalizate figurau mereu în ipostaze de donatori, celelalte - cu preponderență în stadii de receptori.

Astfel, spre exemplu, în cadrul relaţiilor literare Moldova - Ucraina, situația se prezintă în felul următor: în RASSM, între anii 1924-1940, au fost traduse 40 de cărți ale scriitorilor ucraineni, iar în Republica Moldova, din 1940 până în 1984, au apărut 88 de unități editoriale ${ }^{1}$. Deși în anii '30 editurile din Ucraina au întreprins 2-3 încercări foarte modeste de a transpune câte ceva din scrierile literare apărute în RASSM, un veritabil proces de traducere a pornit doar în 1953. De atunci și până în prezent, editurile din Ucraina au elaborat 66 de cărți ce cuprind scrieri diferite ca gen și specie. Deci, un dialog literar româno-ucrainean real funcționează doar în ultimele şapte decenii. Cât privește necesitatea unei astfel de comunicări literare, reproducem constatarea care aparține dlui Dan Grigorescu, critic literar și de artă, specialist în probleme de literatură comparată (autor al studiului „Introducere în literatura comparată. Teoria”. București, Univers, 1982), traducător în română al unor capodopere ale lui W. Shakespeare: „Principalele întrebări puse de cultură, accentuează el, sînt nu neapărat cele ale creației, ci cele ale receptării”’’.

Ipostaza de donator a Republicii Moldova, în cadrul dialogului literar nominalizat, a început a funcționa cu o întârziere de 3 decenii. Printre operele publicate, prioritatea îi aparține genului epic, or, cititorului ucrainean i s-a pus la dispoziție 30 de volume de scrieri în proză. Multiple și numeroase sunt lucrările științifice (studii monografice, culegeri de articole, recenzii și eseuri) editate în R. Moldova și Ucraina care reflectă diverse aspecte ale dialogului intercultural și literar româno-ucrainean, însă principiile și modalitățile de selectare a operelor artistice românești recreate în limba ucraineană nu au fost până acum discutate.

De menționat că procesul de traducere a prozei noastre pentru maturi a cunoscut două modalități de recreare: versiuni obișnuite și autorizate. De prima modalitate țin scrierile: „Dimineața pe Nistru” de Ion Canna, „Tovarășul Vanea” de Samson Șleahu, „Povara bunătătii noastre” de Ion Druță, „Mesagerii” de Alexei Marinat, „Ninsori în primăvară” de Gh. Gheorghiu și „Podgorenii” de Ion C. Ciobanu; cea de-a doua modalitate a fost aplicată următoarelor opere: „Frunze de dor” și „Ultima lună de toamnă” de Ion Druță, „Codrii” de Ion C. Ciobanu, „La cântatul cucoșilor” de Ana Lupan, „Acasă” de Vl. Beșleagă, „Elegie pentru Ana-Maria” de Vasile Vasilache și „Omul din oglindă” de Nicolae Vieru.

${ }^{1}$ Date concrete în acest sens aflăm în studiul monografic: Dumitru Apetri. Dialog intercultural. Aspecte ale receptării literare. Chișinău: CEP USM, 2006. - 170 p.

${ }^{2}$ Grigorescu, Dan. O carte antrenantă. În: Viața Românească, 1993, nr. 6-7, p. 154. 
Alături de traducători, în procesul de includere a prozei românești în contextul literar ucrainean, au participat și personalități din domeniul culturii. Spre exemplu, redactorii de text: V. F. Baranov, Z. I. Reabcik, V. O. Kornienko, V. I. Kolegova, Z. G. Kovali ș.a.; pictorii și graficienii: V. A. Kononenko, I. M. Gavriliuk, L. Nikitin, V. T. Goncearenko, V. V. Rudenko, E. G. Muștenko, V. V. Kuzmenko ș.a.

O privire generală asupra selectării prozei (aici ne referim doar la edițiile pentru maturi) scoate în evidență următorul tablou: au fost alese, traduse și editate doar scrieri plăsmuite în spațiul pruto-nistrean în perioada sovietică. $\mathrm{O}$ atare predilecție a impus contextului receptor o imagine trunchiată și incompletă a genului literar respectiv. Situaţia creată o datorăm amestecului grosolan și primitiv al politicului în procesul comunicării literar-culturale între națiuni. La mijloc ar fi promovarea preceptului ideologic eronat precum că literatura creată în perioada sovietică reprezintă o etapă superioară a evoluției literare desfășurate în decurs de secole, adică până la această orânduire statală. În realitate, starea de lucruri e de altă natură. Spre regret, o atare orientare scoate în vileag încă o scăpare profund regretabilă absența totală a prozei românești din regiunea Cernăuți. Regretul persistă și prin faptul că oamenii de cultură români din zona respectivă (scriitorii Vasile Levițchi, Mircea Lutic, Grigore Bostan, Ilie T. Zegrea, Grigore Crigan, Simion Gociu, Vasile Tărâțeanu, profesoara universitară poliglot Zinaida Peniuc și unii dintre jurnaliști și publiciști) se manifestă ca traducători foarte activi de literatură ucraineană clasică și contemporană. Dar să trecem la ceea ce s-a realizat.

Bucură faptul că printre cele 15 unități editoriale destinate cititorilor maturi figurează Ion Druță, cel mai de seamă prozator basarabean din ultimele şapte decenii, cu romanele „Frunze de dor” (în variantă ucraineană - „Gheorghe, fecior de văduvă"2), „Povara bunătății noastre” și cu povestirea antologică „Ultima lună de toamnă"; prozatorii Vladimir Beșleagă (pânza epică „Acasă”), Vasile Vasilache și George Meniuc cu povestirile de proporții „Elegie pentru Ana-Maria”, „Delfinul” ș.a.; Alexei Marinat, Nicolae Vieru, Gheorghe Gheorghiu și Ana Lupan cu romanele „Mesagerii” și „Fata cu harțag”, şi respectiv, „Omul din oglindă”, „Ninsori în primăvară”, „La cântatul cucoșilor”. Aceste scrieri epice formează o bună parte a potențialului de bază al genului epic creat în Basarabia în a doua jumătate a sec. al XX-lea. Bibliografia traducerilor cuprinde însă și scrieri ticluite în spiritul realismului socialist: dilogia „Codrii” și „Podgorenii” de Ion C. Ciobanu, „Dimineața pe Nistru” de Ion Canna și „Tovarășul Vanea” de Samson Șleahu.

Ultimele trei scrieri, calificate la timpul lor ca romane, rămân a fi mărturii ale perioadei potrivnice spiritului creator, iar în cadrul spiritualității ucrainene nu sunt capabile nici să contribuie la o cunoaștere veridică a realităților basarabene, nici să aducă un oarecare spor la imaginea autentică a genului epic din care, în virtutea împrejurărilor, fac parte. Păcat că aceste plăsmuiri tendențioase, anemice și bicisnice, care promovau ideologia comunistă, au apărut în limba lui Taras Șevcenko în tiraje ce variază între 15 și 65 de mii de exemplare.

Am enumerat mai sus vreo zece pânze epice care, după convingerea noastră, formează partea ponderabilă a genului epic basarabean recreat de ucraineni în limba lor maternă. Prezența acestor opere în cadrul dialogului literar româno-ucrainean e salutabilă, însă satisfacția sporește și mai mult când aflăm printre promotorii 
operelor nominalizate personalităţi de seamă ucrainene: scriitori, tălmăcitori, cercetători literari etc.

În prima jumătate a anilor '80, două edituri din Ucraina au întreprins noi eforturi de completare a arsenalului epic basarabean editând următoarele trei culegeri antologice: „Nuvelistica sovietică moldovenească” (Kiev, Dnipro, 1980.), selecție de Ion Podoleanu, serialul „Nuvela sovietică”; „Melodiile codrilor” (Kiev, Molodi, 1984), prefață de Vladimir Beșleagă, alcătuire de Eugen Lungu, serialul „Proza tânără a țării”; „Povestirea sovietică moldovenească” (Kiev, Dnipro, 1985), antologator fiind savantul filolog Stanislav Semcinsky - promotor activ al dialogului cultural-literar româno-ucrainean.

Primul volum conține nuvele ce aparțin generației în vârstă de scriitori: Ion Druță, George Meniuc, Vladimir Beșleagă, Pavel Boțu, Aureliu Busuioc, Vasile Vasilachi, Vlad Ioviță, Alexei Marinat, Mihail Gh. Cibotaru, Ariadna Șalari ș.a. A doua culegere întrunește scrieri ale prozatorilor din promoția relativ tânără pe atunci (anii '80): Lida Istrati, Haralambie Moraru, Ion Bogatu etc. În prefața „Pe cărările sufletului”, V1. Beșleagă relevă că, prin anii '80, proza moldovenească a obținut întâietate în peisajul literar autohton și că se dezvoltă pe două căi: prima însuşirea celor mai bune tradiții ale creației populare și ale culturii clasice; a doua - apropierea de modalităţile tehnice ale prozei contemporane. A treia unitate editorială cuprinde doar patru povestiri semnate de scriitori diferiți ca vârstă: Ion Druță, Aurel Scobioală, Ariadna Șalari și Nicolae Vieru.

Am menționat mai sus ca factor pozitiv și îmbucurător prezența în listă a operelor narative semnate de scriitori basarabeni dintre cei mai valoroși: Ion Druță, George Meniuc, Vladimir Beșleagă, Vasile Vasilachi și Nicolae Vieru. Următorul factor benefic, în cadrul domeniului discutat, este prezența scriitorilor, a traducătorilor și a cercetătorilor literari ucraineni dintre cei mai valoroși, deci e necesar să scoatem în evidență, în primul rând, individualitatea traducătorilor. Asupra interpretărilor critice (studii propriu-zise, introductive, prefețe, postfețe, adnotări) ne vom expune într-un articol aparte ${ }^{3}$.

Prima personalitate de spiritualitate ucraineană care se cuvine menţionată este Stanislav Semcinsky, eminent savant şi om de cultură, cunoscător perfect al limbilor ucraineană şi română. În acţiunile de promovare a prozei româneşti în ţara vecină, S. Semcinsky este cunoscut ca traducător, prefaţator şi antologator, aducând o contribuție cu adevărat solidă. El transpune în ucraineană povestirile „Demobilizarea” de Ion C. Ciobanu, „Oameni obişnuiţ̧” de Iosif Gaisaniuc şi „La un pahar de vin” de Ariadna Şalari; scrie prefeţe la romanul „Codrii” de Ion C. Ciobanu şi la volumul „Delfinul: nuvele şi povestiri” de George Meniuc; alcătuieşte culegerea antologică „Povestirea contemporană moldovenească”.

În calitate de recreatori ai scrierilor epice românești s-au manifestat și alte câteva personalităţi. Romanele „Frunze de dor” de Ion Druţă şi „Fata cu harţag” de Alexei Marinat s-au plasat în albia limbii ucrainene datorită lui Ivan Glinskii poet, autor de scrieri dramatice („Când florile explodează”, „Vă aşteaptă mamele”),

${ }^{3}$ Informații privind modalitatea de traducere, anul apariției, denumirea editurilor, serialul de scrieri, numele ilustratorilor și tirajul le aflăm în lista bibliografică anexată textului de față. 
ştiinţifice şi de numeroase tălmăciri în limba lui Taras Şevcenko. Capodopera druţiană „Povara bunătăţii noastre”, povestirile antologice „Ultima lună de toamnă” şi „Clopotniţa”, precum şi romanele „La cântatul cucoşilor” de Ana Lupan, „Acasă” de Vladimir Beşleagă, „Omul din oglindă” de Nicolae Vieru, povestirile „Scorbura” de Ana Lupan şi „Pomul lui Arsene” de Victor Prohin au fost transpuse în ucraineşte de Marina Slovianova, una dintre cele mai active traducătoare de opere literare româneşti create în spaţiul pruto-nistrean.

Prodigiosul scriitor Andrii Miastkivskii (căriua îi aparţin vreo 20 de volume de poezie pentru maturi şi copii, trei romane, cinci cărţi de povestiri şi nuvele, un şir solid de traduceri) a adus pe masa cititorului ucrainean volumul „Delfinul: nuvele şi povestiri” de George Meniuc, povestirile „Pianista şi strungarul” de Aureliu Busuioc şi „Fata de la țară” de Gheorghe Urschi. La tălmăcirea romanului „Mesagerii” de Alexei Marinat, a povestirii „Elegie pentru Ana-Maria” de Vasile Vasilache, „Florile pământului”" de Raisa Lungu, „Tăietorii de pădure” de Nicolae Roşca ş.a. a trudit criticul literar şi traducătorul Volodimir Pianov - personalitate care s-a impus în contextul autohton cu un şir de versiuni ucrainene din literaturile bielorusă şi română.

Dintre traducătoarele ucrainene se prezintă cu o contribuţie solidă Galina Berejna. Romanele „Ninsori în primăvară” de Gheorghe Gheorghiu, „Podgorenii” de Ion C. Ciobanu, povestirile „Maria” şi „Motanul sălbatic” de Nicolae Vieru, „Glasul din preajma somnului” de Victor Dumbrăveanu, „Prăpastia” de Silvia Celac şi „Povestiri scurte” de Anatol Gondiu poartă semnătura acestei doamne, care a efectuat tălmăciri din proza lui M. Sadoveanu, Titus Popovici şi Iuliu Raţiu.

Povestirea Ariadnei Şalari „Dâmbul unde nu se pune vie” a căpătat veşmânt lingvistic ucrainean prin pana experimentatului interpret Mikola Cişcevîi. Datorită acestui traducător, dăinuie în spațiul literar ucrainean un şir de pânze epice româneşti: „De neamul şoimăreştilor” de Mihail Sadoveanu, „Jocul cu moartea” de Zaharia Stancu, „Castelul fetei în alb” de Constantin Chiriţă, „Inundaţie” de Alexandru Ivasiuc, „Toate pânzele sus” de Radu Tudoran ş.a. Se cuvine să-l pomenim aici şi pe poetul şi traducătorul ucrainean Olexa Noviţkii care a trudit asupra scrierii lui Ion Canna „Dimineaţa pe Nistru”.

$\mathrm{Nu}$ am fi obiectivi dacă am afirma că în procesul de traducere a prozei din R. Moldova şi-au adus contribuţia doar figuri literare de primă mărime. De exemplu, pe foaia de titlu a fabricatei scrieri a lui Samson Şleahu ,Tovarăşul Vanea" sunt imprimate două nume: V. Babii şi O. Skripnik, care nu figurează ca scriitori sau tălmăcitori nici în cele două volume bibliografice „Scriitorii Ucrainei Sovietice", scoase de sub tipar la editura "Scriitorul Sovietic" în anii '80, nici în solidul tratat „Istoria literaturii ucrainene”, vol. 2 (Kiev, Naukova dumka, 1988), elaborat de Institutul de Literatură „Taras Şevcenko” al Academiei de Ştiinţe a RSS Ucrainene - lucrări de referinţă, care reflectă activitatea scriitoricească din a doua jumătate a secolului al XX-lea (sursele sunt, bineînțeles, în limba ucraineană).

Despre procesul de receptare a prozei românești din spaţiul de la est de Prut în Ucraina s-a scris foarte puțin. Dacă facem abstracție de cele câteva prefețe, 


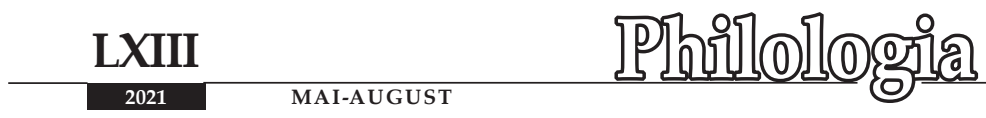

postfețe și adnotări ce figurează în cărţile traduse, ne pomenim în posesia doar a următoarelor articole: Alexandrina Cernov, profesoară la Universitatea de Stat din Cernăuți: „Переклади I. Друце українською мовою” („Traduceri din I. Druță în limba ucraineană”). În: Актуальні пітання суспільних наук, історії, філології. Львів, 1974; Nicolae Bogaiciuc, director al Școlii pedagogice din Cernăuți. „Творчество Йона Крянгэ на Украине”. În: „Limba și literatura moldovenească”, 1979, nr. 2; „Creangă în limba ucraineană. Omagiu la 80 de ani de la moartea scriitorului". În: Zorile Bucovinei, 1969, 31 decembrie; „Творець чарівних казок” („Creator de povești fermecătoare”). În: Радянська Буковина, 1970, 20 ianuarie (traducerile acestor denumiri din ucraineană aparțin subsemnatului); N. Florea-Cimpoi „Nuvela moldovenească în limba ucraineană” (Tinerimea Moldovei, 1980, 7 octombrie). Ne oprim aici, deoarece principalii promotori ai prozei noastre în albia spiritualității ucrainene sunt indicați în lista bibliografică anexată la articol.

In anul 2022 se vor împlini trei decenii de la apariția ultimei cărți de proză basarabeană tradusă și publicată de ucraineni. În speranța că dialogul intercultural româno-ucrainean va fi reluat de curând și va avea ca scop includerea în circuitul literar și a unor opere din patrimoniul epic de până la 1940, propunem câteva nume și opere importante create în spațiul Basarabiei și în localitățile românești din actuala regiune Cernăuți.

Spațiul Basarabiei. Bogdan Petriceicu-Hasdeu: nuvela „Micuţa”, Alecu Russo: legendele „Piatra Teiului” și „Stânca corbului”, Alexei Mateevici: nuvela „Toamna”, Constantin Stere: bildungsromanul „În preajma revoluției” și povestirea "In voia valurilor. Icoane din Siberia", Gheorghe V. Madan: povestirea "Ciubotelele lui Ionel”, nuvelele „Pățania lui Irimia Pârțag”, „Tinerei și străinei”, „Așa-i războiul”, „Povestea unui cântec vechi” ș.a., Leon Donici: romanele „Noul seminar”, „Revoluția rusă”, nuvelele „Marele Arhimedes”, „Recviem” și „Anticrist”.

Dintre prozatorii basarabeni contemporani, când se va purcede la selectarea operelor pentru traducere, merită atenție: Vladimir Beșleagă: romanul „Viața și moartea nefericitului Filimon sau Anevoioasa cale a cunoașterii de sine", Nicolae Dabija: romanele „Tema pentru acasă”, „Te blestem să te îndrăgostești de mine”, Victor Dumbrăveanu: „Nesomnul bărbaților”, „Iubirea noastră-i ca și ura”, Elena Damian: romanul „Spulber”, Petru Cărare: volumul de proze umoristice „Zodia musafirului”, Nicolae Rusu: romanele „Lia”, „S,obolaniada”, „Al șaptelea simț”, „Cu ochii celuilalt”, Aurelian Silvestru: „Fărâme de suflet”, Ghenadie Postolachi: romanele „Pastorala” , „Lecții de fotosinteză”, proza scurtă „Sezonul cerșetorilor”.

Nordul Bucovinei și ținutul Herța. Gheorghe Asachi: nuvela „Sfidrighelo”, cronica romanțată „Elena Moldovei”, Vasile Gherasim: nuvela „Înspre soare”; Mircea Streinul: romanele „Ion Aluion”, „Lupul din Țara Huțulilor”, „Drama Casei Timoteu" - toate trei s-au bucurat de aprecieri din partea savanților filologi Perpessicius, Ion Simuț și a scriitorului Ion Radu Paraschivescu; Anița NandrișCudla: romanul „20 de ani în Siberia. Destin bucovinean”, în 1992 această scriere se învrednicește de Premiul „Lucian Blaga” al Academiei Române; Grigore Bostan: „O evadare în Eterna 1", Serafim Saka: romanele „Vămile”, „Linia de plutire”, volumul de proză „Era târziu”; Gr. Crigan: „Vornicul Miron”, nuvelă istorică; Viorica Chibac-Cuciureanu: „La răspântia Boianului”, Dumitru Hrinciuc: „Când 
frunzele se despart de ramuri”, „Vișinul”, nuvele; Mihai Prepeliță: romanele „Îmblânzirea curcubeului”, „Tânguiosul glas de clopot”, „Vântul și măștile”, povestirea „Mama noastră - Pasăre albastră”; Gheorghe Calamanciuc: romanele „Don Juan de mucava”, „Celebritatea ghinionistului”, „Cerul din Ilicatinca”, volumele de povestiri și nuvele „Vise cu brândușe”, „Să-ți fie dor de tine”; Simion Gociu: „Priporul căprioarelor”, proză; Ștefan Broască: „Hăitași de clipe”, proză; Nicolae Spătaru: „Îngerașul poartă fustă mini”, proză scurtă; „Măștile lui Brejnev”, roman; Dumitru Apetri: „Amurguri”, proză ${ }^{4}$.

Concluzii. E salutabil faptul că în ultimele şapte decenii între R. Moldova și Ucraina se desfășoară un dialog literar real prin intermediul traducerilor artistice. Diverse ca gen și specie, cele 66 de cărți create în spațiul românesc de la est de Prut și traduse în limba ucraineană, dintre care 30 de volume aparțin genului epic, constituie o dovadă certă în acest sens. Majoritatea dintre proze sunt opere valoroase, dar, din cauza dictaturii ideologice, figurează și câteva volume ticluite în spiritul realismului socialist. E regretabil faptul că selecția scrierilor epice s-a făcut doar din ceea ce a fost creat în R. Moldova, ignorânduse patrimoniul epic de până la 1950 și neluându-se totalmente în seamă producția narativă românească făurită în nordul Bucovinei și în ținutul Herța. Astfel, contextului receptor i s-a impus o imagine trunchiată și incompletă a genului epic creat în perimetrii geografici și spirituali respectivi.

\section{Bibliografia traducerilor de proză (ediții pentru maturi):}

Бешляге Володимир. Вдома. Роман. Traducere autorizată din mold. de Marina Slovianova. Studiu introductiv de St. Semcinsky. Кïev: Видав. худож. л.-рн Дніпро, 1982. 326 р. (col. Comoara literaturilor frăteşti)

Вієру Николає, Друце Йон. Аурел Скобіоале, Аріадна Шалар. Сугасна молдавська повість. Selecţie de S. V. Semcinsky. Trad. din mold. de colectiv de traducători. Note biobibliografice despre autori (р. 231). Київ: Видавництво художньоі літератури Дніпро, 1988. 232 p.

Василаке Василе. Елегия для Анни-Марії. Роман. Повесть. Trad. autorizată din mold. de Vl. Pianov. Київ: Дніпро, 1986. 352 p.

Георгиу Георге. Весняні снігопади. Роман. Trad. din mold. de Galina Berejna. Київ: Дніпро, 1984. 320 p.

${ }^{4}$ Oamenilor de cultură din Ucraina (scriitori, traducători, savanți-filologi și editori), care vor avea intenția să afle date concrete și amănunțite despre operele recomandate de noi pentru selectare și editare, le propunem să consulte următoarele surse bibliografice și exegetice: Dicționarul scriitorilor români din Basarabia. 1812-2010. Ediția a II-a revăzută și completată. Chișinău, Prut Internațional, 2010; Mihai Cimpoi. O istorie deschisă a literaturii române din Basarabia. Ediția a II-a, revăzută și adăugată. Chișinău, Arc, 1997; Alexandru Burlacu. Proza basarabeană: fascinația modelelor. Chișinău, Cartier, 2000; Constantin Loghin. Istoria literaturii române din Bucovina. 1775-1918. Ediție îngrijită de Alexandrina Cernov. Cernăuți, Alexandru cel Bun, 1996; Grigore C. Bostan, Lora Bostan. Pagini de literatură română. Bucovina, regiunea Cernăuți. 1775-2000 (compendiu și antologie). - Cernăuți. Alexandru cel Bun, 2000; Emil Satco, Alis Niculică. Enciclopedia Bucovinei in trei volume. - Suceava, Editura Karl A. Romstorfer, 2018. 
Друце И. Георге, удовин син. Повість. Trad. autoriz. din mold. de I. Glinski. Київ: Держав. видав, худож. літ-рu, 1961. 164 р.

Друце И. Останній місящь осені. Повість. Trad. autoriz. din mold. de M. Slovianova. Ilustraţii de L. Nikitin. Київ: Дніпро, 1979. 80 р.

Друце И. Сила доброти нашої. Роман. Prefaţă de I. Pitlear. Trad. din mold. de M. Slovianova. Київ: Дніпро, 1972. 302 p. (col. Izvoarele frăţiei).

Канна И. Ранок на Дністрі. Роман. Trad. din mold. de O. Noviţki. Київ: Держлітвидав, 1954. 204 p.

Лупан А. Tреті півні. Роман. Prefaţă de V1. Beşleagă. Trad. autoriz. din mold. de M. Slovianova. Київ: Дніпро, 1977. 287 p. (col. Comoara literaturilor frăţeşti).

Маринат О. Невгамовна дівчина. Роман. Trad. autoriz. din mold. de I. Glinski. Київ: Молодь, 1962. 310 р.

Маринат О. Посланц̧і. Роман. Trad. din mold. de V. Pianov. Київ: Молодь, 1978. $253 \mathrm{p}$.

Менюк Дж. Дельфін: оповідання і повісmь. Prefaţă de S. Semcinsky. Trad. din mold. de A. Miastкivski. Київ: Дніпро, 1976. 176 p. (col. Comoara literaturilor frăţeşti)

Чобану И. Кодри. Роман. Prefaţă de S. Semcinsky. Trad. autoriz. din mold. de I. Ilienко. Київ: Дніпро, 1970. 287 р.

Чобану Йон. Підгоряни. Роман. Trad. din mold. de Galina Berejna. Київ: Видавництво художньої літератури „Дніпро”, 1988. 456 р.

Шляху С. Товарии Ваня. Повість. Trad. din mold. de V. Babii şi O. Skripnik, desene de C. Caruţeak. Київ: Дитвидав УРСР, 1962. 195 p.

Notă: Articolul a fost realizat în cadrul proiectului de cercetare 20.80009.1606.03 Contexte socioculturale autohtone şi interconexiuni europene în creaţia populară şi literatura cultă din Basarabia (sec. XIX până în prezent), Institutul de Filologie Română „B. P.-Hasdeu” al MECC. 


\title{
STRUCTURI FUNDAMENTALE CU PRONUME REFLEXIV LA CAZUL DATIV ÎN LIMBA ROMÂNĂ \\ Elena CONSTANTINOVICI
}

\author{
Doctor habilitat în filologie, profesor universitar \\ E-mail: elcon23@yahoo.com \\ ORCID: https://orcid.org/0000-0003-0007-9663 \\ Institutul de Filologie Romană „Bogdan Petriceicu-Hasdeu” (Chișinău)
}

\section{Fundamental Structures with Reflexive Pronoun in Dative in Romanian}

\begin{abstract}
This article focuses on the problem of the functioning of the reflexive pronoun in dative modifying the verb. Based on a substantial corpus, the article refers to the delimitation of its functions, values and nuances, as well as the various fundamental structures in which it appears. Three constructions with their afferent structures are described, from which it appears that the reflexive dative works in two ways: 1) the subcategorization of the verb, receiving the thematic role of recipient or beneficiary and syntactic function of indirect object and 2) the double subordination - to the verb and to a noun in the structure. That is, it does not occupy a position of subcategorization of the verb, but acquires a possessive meaning from this noun and fulfills the function of possessive object, a function without a thematic role.

Keywords: reflexive pronoun, clitic, dative, actant, the thematic role, reciprocal value, possessive value, syntactic construction.

\section{Rezumat}

Prezentul articol se axează pe problema funcționării pronumelui reflexiv în dativ pe lângă verb. Bazat pe un substanțial corpus, articolul se referă la delimitarea funcțiilor, a valorilor și a nuanțelor pronumelui reflexiv în dativ, precum și a diverselor structuri fundamentale în care apare. Sunt descrise trei construcții cu structurile lor aferente, din care reiese că dativul reflexiv funcționează în două ipostaze: 1) cea de subcategorizare a verbului, ca actant, primind rol tematic de destinatar sau de beneficiar și funcție sintactică de complement indirect și 2) cea de dublă subordonare - față de verb și față de un nominal din structura respectivă. În această ipostază, nu ocupă o poziție de subcategorizare a verbului, ci dobândește o semnificație de posesiv de la acest nominal şi îndeplinește funcția de complement posesiv, funcție fără rol tematic.

Cuvinte-cheie: pronume reflexiv, clitic, dativ, actant, rol tematic, valoare reciprocă, valoare posesivă, construcție sintactică.
\end{abstract}




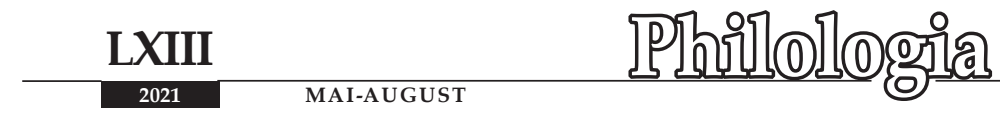

Conform definiţiei, pronumele reflexiv „evocă (= reprezintă) în discurs participanții la actul de comunicare și simultan reflectă identitatea referențială dintre doi actanți implicați în actul predicatiei.” (GALR, I, 2005, p. 222). Pronumele reflexiv este eterogen din punct de vedere morfologic, sintactic și funcțional. Morfologic, pronumele reflexiv se caracterizează printr-o paradigmă defectivă, având forme doar pentru 2 cazuri - dativ și acuzativ: ,a) Dativul se folosește atunci când subiectul și obiectul indirect este una și aceeași persoană. În acest caz acțiunea verbului predicat se înfăptuiește în favoarea subiectului: Omul harnic ișsi face iarna car și vara sanie; b) Acuzativul se folosește atunci când subiectul și obiectul direct este una și aceeași persoană, ceea ce înseamnă că acțiunea verbului-predicat se răsfrânge asupra subiectului însuși: Adesea cel care ajută pe altul se ajută pe sine." (Bărbuță, Constantinovici, 2019, p. 83). Are două serii de forme: accentuate și neaccentuate (clitice). Nu marchează distincția de gen și de număr. Are forme doar pentru persoana a 3-a. La pers. întâi și a 2-a se folosesc formele pronumelui personal care capătă valoare reflexivă atunci când marchează identitatea subiectului cu obiectul indirect sau direct. Sintactic, pronumele reflexiv ,participă la relațiile de actanță ale verbului (...) sau se asociază, prin intermediul verbului, unuia dintre complementele acestuia." (GALR, II, 2005, p. 145). Cu alte cuvinte, pronumele reflexiv se manifestă, din punct de vedere sintactic, în relație cu verbul și cu complementele acestuia, ocupând una din pozițiile de subcategorizare a verbului. Funcțional, reflexivul îndeplinește un rol important în procesul de comunicare, oferind locutorului posibilitatea de a alege din mai multe mărci pentru exprimarea unei anumite funcții. Și, în sfârșit, este de subliniat faptul că „Pronumele reflexiv nu are referință proprie (nu trimite, singur, la un referent), ci și-o procură prin mecanisme anaforice." (GB, 2010, p. 112). Un grad superior de precizie și de rigurozitate în ceea ce privește explicarea eterogenității pronumelui reflexiv în limba română îl găsim într-un amplu și bine documentat articol, semnat de Andra Șerbănescu (1994, p. 143-144).

Studiul de față se axează pe problema funcționării pronumelui reflexiv în dativ pe lângă verb, cu delimitarea funcțiilor, a valorilor și a nuanțelor acestuia, precum și a diverselor structuri fundamentale în care apare. Mioara Avram menționa că „Formele accentuate în dativ sunt puțin întrebuințate în limba contemporană” (Avram, 1997, p. 168), de aceea vom acorda o atenție mai mare cliticului. Scopul primordial al studiului de față nu constă doar în identificarea și descrierea structurilor în care apare pronumele reflexiv în dativ, ci, mai ales, în ilustrarea lor cu exemple, excerptate din materialul de limbă selectat pentru tema Proiectului „Structurile fundamentale ale limbii române" la care se lucrează în prezent la Sectorul de gramatică al Institutului de Filologie „Bogdan Petriceicu-Hasdeu”. Pentru a economisi spațiu, ilustrarea se va face uneori doar cu sintagme, fără nominalul-subiect: a-și construi o casăa, a-și face temele etc.

Spre deosebire de pronumele reflexiv în acuzativ, pentru care contează valoarea derivativă, intranzitivă/ tranzitivă, participarea la procedeul derivării actanțiale și funcționarea ca morfem gramatical diatezial (Constantinovici, 2019, p. 3-9), pronumele reflexiv în dativ dezvoltă alte valori. El poate fi: a) argument/ actant al centrului verbal, făcând parte din lista de valențe ale verbului; b) procedeu 
de redare suplimentară a valorii reciproce; c) procedeu de redare suplimentară a valorii de posesiv. Valoarea posesivă se actualizează atât pe lângă verbe, cât și pe lângă substantive și adjective. Respectiv, pronumele reflexiv în dativ se folosește în mai puține construcții. După cum s-a stabilit deja în lucrările de specialitate, reflexivul în dativ apare în 3 tipuri de construcții:

1) Construcții în care reflexivul în dativ marchează identitatea referențială dintre subiect și obiectul indirect: a-și alege o profesie, a-și crea un nume, a-și permite anumite excese, a nu-și refuza nimic etc.

În cadrul acestor construcții, verbul exprimă o acțiune care se înfăptuiește în favoarea subiectului, iar reflexivul în dativ este folosit cu valoarea lui reflexivă propriu-zisă, participând la poziția de subcategorizare a centrului verbal, poziție matricială, obiectuală. Reflexivul în dativ are o funcție sintactică, regizată de verb, și anume funcția de complement indirect: cliticul $\hat{\imath s ̦ i}$, -și: El isși este sieși primul dușman. Se probează prin fenomenul dublării cu forma accentuată: sieși. Se folosește pe lângă verbe tranzitive cu tranzitivitatea consumată (fie printr-un nume în acuzativ, fie propozițional), cu sau fără alte compliniri. Marea majoritate a verbelor regizează un complement indirect exprimat prin pronume reflexiv în dativ în diferite structuri.

$\mathbf{S}+\mathbf{C}$. ind. + Pr. + C. d. ${ }^{1}$ : a-și aminti numele cuiva, a nu-și aminti trecutul, a-și crea o clientelă, necazuri, o reputație bună, o situație; a-și imagina ceva, a-și interzice orice bucurie, orice plăcere; a-și imputa ceva, a-și însuși o descoperire, un drept, un titlu; a-și însuși cunoștințe, o limbă străină; a-și însuși un principiu, părerea cuiva, punctul de vedere al cuiva; a-și închipui lucrurile altfel decât sunt; a-și cumpăra mobilă; a-și nota ceva, a-și permite excese, luxul; a-și permite multe; a nu-și permite familiarități; a-și reproșa ceva.

$\mathbf{S}+\mathbf{C}$. ind. + Pr. + C. d. + C. prep./ C. circ.: a-și crea probleme din ceva, a-și crea motive de enervare din nimic; a-și păstra provizii pentru iarnă; a-și trage cearşaful peste cap, pălăria peste față, un pulover peste cap.

$\mathbf{S}+\mathbf{C}$. ind. + Pr. + C. prep.: a-și aminti de un profesor, de un prieten, de părinți; a-și aminti de trecut, de anii de școală, de tinerețe, de o treabă urgentă, de o întâmplare; a-și reveni din uimire, din surpriză, din leșin, din moleşeală, din stres/ starea stresantă, din amorţire, din ameţeală, din starea de dormitare/ somn.

S + C. ind. + Pr. + P. c. d.: a-și dori să plece într-o călătorie; a-şi imagina că a câștigat la loterie; a-și permite să achiziționeze ceva, să folosească ceva, să bea o bere, a nu-și permite să aștepte; a-și reproșa că n-a luat o notă mai mare.

2) Construcții în care pronumele reflexiv în dativ dobândește o semnificație suplimentară de reciproc: $a$-și da referințe unul altuia, a-și mulțumi unul altuia, a-și povesti unul altuia viețile, a-și uni destinele, a-și uni soarta cu cineva, a-și zâmbi unul altuia.

În GALR (I, 2005, p. 225) se menționează că „Majoritatea verbelor care participă la construcții cu semnificație reflexivă pot participa și la construcții în care

${ }^{1}$ Aici și în continuare simbolurile din schemă reprezintă următoarele funcții sintactice: S - subiect; Pr. - predicat; C. ind. - complement indirect; C. d. - complement direct; C. prep. - complement prepozițional; P. c. d. - propoziție completivă directă; C. circ. complement circumstanțial; C. pos. - complement posesiv. 


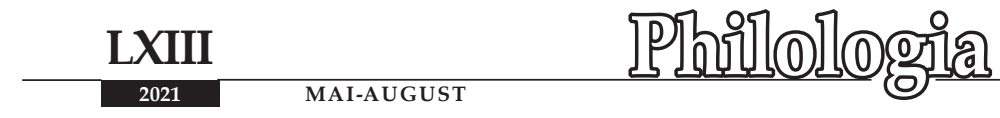

pronumele reflexiv dobândește suplimentar valoare reciprocă. (...) Semnificația reciprocă reflectă o relație simetrică între actanții implicați în acțiunea sau starea exprimată de verb: Dan și Ion își dau bună ziua. Ana și Corina și-au corectat lucrările una alteia. Ele/ Fetele şi-au corectat lucrările una alteia". În aceste construcții biactanțiale, acțiunea se înfăptuiește în favoarea/ defavoarea actanților implicați de verb, aceștia având rol dublu. Ceea ce înseamnă că fiecare indică faptul că acțiunea verbului se extinde concomitent sau alternativ asupra celuilalt participant, adică îmbină ipostazele de subiect și obiect ale unor acțiuni diferite ca orientare. Condiția impusă sintactic este ca subiectul (exprimat fie prin substantiv, fie prin pronume personal) să fie multiplu sau la plural. Ion și Maria (Prietenii/ Ei) iși spun păsul (unul altuia). Așadar, „Indiferent de forma de caz, cliticul reflexiv reciproc are statut pronominal de dublu substitut, înlocuind simultan două nominale din structura primară. (...) Cliticul pronominal ocupă, în funcție de caz (acuzativ sau dativ), poziția de complement direct sau indirect. Ca orice complement, participă la fenomenul dublării, grupurile pronominale (unul pe altul/ celălalt; unul altuia/ celuilalt) apărând cu rol emfatic și dezambiguizator în construcțiile cu dublare." (GALR, II, 2005, p. 162-163).

S + C. ind. + Pr. + C. d.: Ana și Maria își trimit bilețele la cursuri. Ana și Maria iși împrumută bani. Soții iş̦i reproșează trắdarea. Prietenii își strâng mâinile.

$\mathbf{S}+\mathbf{P r}$. + C. ind.: Prietenii își zâmbesc. Ei își sunt dragi unul altuia. Nu-si vorbesc unul altuia.

În structurile simetrice cu subiect multiplu este permisă schimbarea ordinii actanților: Ana îi împrumută bani Mariei. vs Maria îi împrumută bani Anei.

3. Construcții în care pronumele reflexivîn dativ dobândește o semnificație suplimentară de posesiv: a-și apăra interesul; a-și achita taxele; a-și antrena mintea; a-și deschide o prăvălie, a-și controla comportarea, a-și exprima părerea, a-și povesti pățania.

În aceste construcții funcționează doar forma neaccentuată a pronumelui reflexiv în dativ: își/ -și, care are o dublă subordonare - față de verb și față de un substantiv determinant din structura respectivă. (Felecan, 2010, p. 161) Conform GALR, acesta nu ocupă o poziție de subcategorizare a verbului, el fiind ,atras din afara grupului, provenind dintr-un GN-complement direct subordonat verbului centru (interesul său)" (II, 2005, p. 147). Cu alte cuvinte, semnificaţia posesivă nu este regizată de verb, ci de un nume coreferențial cu subiectul. Izabela Celmare, într-un studiu foarte argumentat despre cliticele românești, menționează în legătură cu acest fapt următoarele: „Cliticele (...) purtătoare ale unei valori suplimentare (+ poss) au un statut diferit de corespondentele lor obiectuale; deși argumente, sunt inserate în ArgPoss și realizează un lanț de coindexare trinar, al cărui centru este un Nominal." (Celmare, 2003). Suntem de acord cu această părere, cu condiția ca statutul argumental al cliticului posesiv în dativ să rămână discutabil.

Semnificația suplimentară posesivă poate fi probată prin ,posibilitatea reluării cliticului în dativ printr-o formă de genitiv sau de adjectiv posesiv". (PanăDindelegan, 1992, p. 76): A-și exprima dezamăgirea (sa). A-şi controla furia (sa). Fiecare ișsi pregătește tema (lui). Posesivul și genitivul de cele mai multe ori rămân neexprimate: Copilul își ia cărțile și pleacă la școală. În GALR (I, 2005, p. 224), se 
menționează că reflexivul posesiv este o anaforă sintactică ce „marchează identitatea referențială dintre subiect și ,atributul” semantic al complementului direct (rar, al complementului prepozițional), îndeplinind funcția sintactică de complement posesiv". Este de menționat că până la apariția GALR au existat fluctuații cu privire la funcția sintactică a cliticului reflexiv în dativ în contextele discutate: de atribut pronominal sau de complement indirect (a se vedea: Asan, 1957, p. 131-139; Felecan, 2010, p. 158-164). După apariția GALR, s-a stabilit că funcția sintactică a pronumelui reflexiv în dativ după verb este de complement posesiv, fapt considerat avantajos de unii specialiști (Felecan, 2010, p. 161).

Pronumele reflexiv în dativ cu valoare posesivă apare într-o structură triactanțială, cu un verb și un nominal care constituie o anumită complinire a verbului:

$\mathbf{S}+$ Pr. + C. pos. + C. d.: a-şi bea şi mințile, banii, salariul; a-şi controla reacțiile, ţinuta; a-şi exprima părerea, acordul, îndoiala, compasiunea, regretul, gratitudinea, sentimentele, recunoştinţa, compătimirea, simpatia, satisfacția, surprinderea, dorința, rugămintea, voința; a-și găsi chemarea, vocația; a-și gusta cafeaua; a-și îndeplini o obligație, o speranță, un vis, scopul, norma de lucru, angajamentele; a-și înfrânge teama, furia, o pornire, instinctele, sentimentele; a-și împlini obligațiile, sarcinile, promisiunile, datoria, cuvântul, visul; a-și lăuda admiratorii; a-și neglija responsabilitățile, serviciul; a-și pierde sănătatea, cumpătul, memoria, controlul, eficacitatea, prospețimea, forța, cunoștința, credința, valoarea; a-și prezenta demisia, scuzele; a-și păstra calmul, cumpătul, seriozitatea, firea, îndemânarea, stăpânirea de sine; a-și reface viața, reputația, forțele, sănătatea, puterile; a-și retrage cuvintele, o pretenție, o declarație, paza; a-și risipi viața, tinerețea, bănuielile, indoielile, frica; a-și ruina sănătatea; a-și schimba numele, adresa, domiciliul, slujba; a-și scoate mănuşile, cizmele, pălăria; a-și stăpâni mânia, supărarea, lacrimile, o pornire, emoțiile; a-și suci glezna; a-și toca averea; a-și toci nervii, palmele; a-și trăda tovarășii, patria, țara; a-și ține respirația, cuvântul, promisiunea; a-și umple buzunarele; a-și vizita pacienții.

S + Pr. + C. pos. + C. d. + C. prep./ C. circ.: a-și găsi refugiul în băuturăa în droguri; a-şi găsi consolare în ceva; a-şi încărca memoria cu prea multe amănunte; a-și lua copilul în brațe, a nu-și lua ochii de la cineva sau ceva; a-și manifesta disprețul față de cineva; a-și obosi ochii cu cititul, cu lucrul de mână; a-și plasa banii într-o afacere; a-și petrece vacanța în Miami; a-și păstra receptivitatea la ceva; a-și pune pe spate un șal; a-și scoate din deget un spin; a-și spăla rufele murdare in public; a-și sprijini afirmațiile pe dovezi serioase; a-și strivi degetul în ușă; a-și toca banii, averea cu chefurile; a-și șterge lacrimile cu batista; a-și șterge mâinile cu un șervet; a-și ține părerile pentru sine; a-și ține capul în mâini.

S + Pr. + C. pos. + C. ind.: a nu-și crede ochilor și urechilor; a-și pune capăt suferinței/zilelor/vieții.

S + Pr. + C. pos. + C. prep.: a-și căuta de casăa, de copii, de ale sale; a-și plânge de milăa; a-şi purta de grijă; a-şi vedea de sănătate; a-şi vedea de treburi.

Pronumele reflexiv în dativ cu semnificație posesivă se angajează la nivel sintagmatic într-o relație cu un nominal ce exprimă: 
Posesie inalienabilă (o parte a corpului, o însușire morală, intelectuală, o stare afectivă): a-și acoperi fața cu mâinile; a-și antrena mintea, mușchii, urechea; a-și ascunde adevăratele convingeri, emoțiile; a-și cere drepturile; a nuși putea ascunde fericirea, euforia; a-și destăinui cuiva sufletul, inima, intențiile, necazurile, emoțiile, ura, dragostea; a-și controla furia; a-și manifesta supărarea, sentimentele, entuziasmul, atașamentul, surpriza, indignarea, simpatia pentru cineva sau ceva; a-și mânca sănătatea; a-și mușca limba, buzele, degetele, mâinile; a-și obosi capul, inima; a-și odihni mintea, picioarele, creierul; a-și opri lacrimile; a-și organiza viața; a-și pierde vocea, silueta, mândria; a-și pieptăna părul, barba; a-și recunoaște greșelile, păcatele, vina; a-și reprima sentimentele, ura, dragostea, a-şi retrăi viața, trecutul; a-și reține lacrimile, plânsul, sentimentele; a-și rezema coatele de masă; a-și roade unghiile; a-și satisface gustul, o plăcere; a-și sprijini capul în mâini; a-și stăpâni sentimentele, o patimă, nemulțumirea, durerea, entuziasmul, energia, exuberanța, plânsul, bucuria, furia, dezamăgirea, nervii, înflăcărarea, ardoarea, indignarea, râsul; a-și suci mâna, piciorul, gâtul, degetele; a-și șterge ochii de lacrimi; a-și șterge fața, sudoarea, transpirația; a-și toci simțurile; a-și ține gura; a-și umfla nările, pieptul; a-și umple burta.

Posesie alienabilă (un lucru, o ființă sau atribuții și obligații): $a$-și aborda şeful; a-și achita taxele; a-și actualiza imaginea de profil; a-și agăța haina în cuier; a-și aranja lucrurile în dulap; a-și bea și cămașa; a-și găsi perechea, o ocupație în timpul liber, a nu-și găsi mănuşile; a-și îndeplini atribuțiile; a-și înfrânge inamicul; a-și jertfi fiica; a-și lăsa valiza la gară, în biroul de bagaje; a-și mânca averea, a-și neglija obligațiile, copiii; a-și ocupa locul, scaunul; a-și odihni calul, trupele; a-și părăsi iubitul, iubita; a-și pierde rangul social, locul, postul, prestigiul, puterile, bunul nume, mandatul, slujba; a-și pune paltonul, pălăria, un șal pe umeri; a-și păstra valabilitatea, avantajul; a-și petrece vara în chefuri, concediul cu familia; a-și respecta clienții; a-și retrage candidatura, oferta, propunerea; a-și reclama drepturile; a-și schimba proprietarul, locuința, locul de muncă, adresa, religia, atitudinea, concepțiile; a-și stăpâni câinii, caii; a-și turna complicii; a-și trăda prietenii; a-și ține cuvântul, o făgăduială, angajamentele; a-și umple buzunarele, punga; a-și vinde complicii, prietenii.

Concluzii. $\mathrm{Cu}$ toate că pronumele reflexiv în dativ are o sferă de funcționare limitată în comparație cu pronumele reflexiv în acuzativ, acesta este totuși destul de răspândit în limbă. După cum arată exemplele din corpusul care stă la baza acestui studiu, cliticul pronominal reflexiv în dativ se folosește în 10 structuri distincte, îndeplinind funcția sintactică de complement indirect și complement posesiv. În primele două construcții, dativul reflexiv este antrenat în relația de actanță a verbului. Având un rol actanțial regizat de verb, reflexivul în dativ ocupă, la nivel sintactic, o poziție de subcategorizare a verbului (cea de complement indirect). În cea de a treia construcție, semnificația posesivă nu este regizată de verb. Cliticul reflexiv în dativ din aceste structuri are o dublă subordonare - față de verb și față de un nominal din structura respectivă, adică acesta nu ocupă o poziție de subcategorizare a verbului, el provenind dintr-un grup nominal subordonat verbului centru și care are funcția sintactică de complement direct. Reflexivul în dativ dobândește o semnificație de posesiv 
de la acest nominal și îndeplinește funcția de complement posesiv, funcție fără rol tematic. Însușirea acestui fapt facilitează delimitarea sensurilor cuvintelor polisemantice. De exemplu, deosebirea dintre a-și impune o regulă de conduită și a-și impune ideile, autoritatea, voința, pretențiile devine clară, dacă se ține cont de cele menționate supra.

\section{Referințe bibliografice:}

ASAN, Finuța. Atributul pronominal în dativ. În: Studii de gramatică. Vol. II. Bucureşti: Editura Academiei Române, 1957, p.131-139.

AVRAM, Mioara. Gramatica pentru toți. Ediția a II-a revăzută şi adăugită. București: Humanitas, 1997.

BĂRBUŢ̆, Ion, CONSTANTINOVICI, Elena. Gramatica limbii române. Chișinău: Pro Libra, 2019.

CELMARE, Izabela. Cliticele pronominale românești în perspectivă minimalistă. În: Aspecte ale dinamicii limbii române actuale. Actele colocviului Catedrei de Limba Română, 27-28 noiembrie 2002, II, Secţiunea Morfosintaxă. Bucureşti: Editura Universităţii din București, 2003. Şi: http://www.diacronia.ro/ro/indexing/details/V3901/pdf

CONSTANTINOVICI, Elena. Despre câteva delimitări tranșante în utilizarea verbelor pronominale în limba română. În: Buletin de lingvistică, 2018-2019, nr. 19-20, p. 3-9.

GB = Gramatica de bază a limbii române. Coordonator, Gabriela Pană-Dindelegan. București: Univers Enciclopedic Gold, 2010.

GALR, I = Gramatica limbii române. Vol. I, Cuvântul. București: Editura Academiei Române, 2005.

GALR, II = Gramatica limbii române. Vol. II, Enunțul. București: Editura Academiei Române, 2005.

FELECAN, Nicolae. Complementul posesiv. În: Limba română, 2010, nr. 3-4, p. 158-164. http://limbaromana.md/?go=numar\&n=19

PANĂ-DINDELEGAN, Gabriela. Teorie și analiză gramaticală. București: Editura Coresi SRL, 1992.

ȘERBĂNESCU, Andra. Pentru un dicționar sintactic al verbelor românești. În: Studii și cercetări lingvistice, 1994, nr. 3-4, p. 133-150.

Notă: Articolul a fost realizat în cadrul proiectului de cercetare 20.80009.1606.01 Valorificarea științifică a patrimoniului lingvistic național în contextul integrării europene, Institutul de Filologie Română „B. P.-Hasdeu” al MECC. 


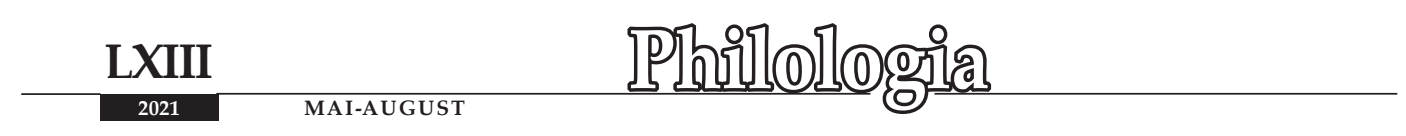

https://doi.org/10.52505/1857-4300.2021.2(314).08

CZU:811.135.1'367.2

\title{
ASPECTE DEFINITORII ALE SUBIECTULUI LOGIC ÎN PROPOZIȚIE
}

\author{
Petru BUtuC \\ Doctor în filologie, conferențiar universitar \\ E-mail: butuc.petru@gmail.com \\ ORCID: https://orcid.org/0000-0001-9667-201X \\ Institutul de Filologie Română „Bogdan Petriceicu-Hasdeu” (Chișinău) \\ Defining Aspects of the Logical Subject into the Sentence
}

\begin{abstract}
Although linguistics, the science of language, has reached a high level of development, anyway in syntax there are still many unsolved problems. A very important problem is the one that identifies the parts of the sentences. Therefore, because of inconsistent application of principles, at the analysis of language acts, at the syntactic level, sometimes the extreme structural-grammatical formalism is reached, which, as a result, superimpose parts of sentences over parts of speech, the criterion which conducts to a morphological interpretation of syntax. Such a syntactical analysis is useless, because it makes impossible the real identification of text ideas.

Grammarians, situated on morphological positions in syntax, are launching different methodological versions this way. One of them would be that the grammar case form is decisive for identification of the parts of sentences. Such a method is less applicable in Romanian, because at the same grammatical form of the case we have several syntactic functions and at the same function - several forms. In this study the author tries to analyze these morphological and syntactic aspects by demonstration, referring, in particular, to the semantic-syntactic status of the logical subject in the sentence.

Keywords: logical and semantic principle, the structural and grammatical formalism, morphological restructuring of syntax, functional syntax, pragmatic aspect, syntagmatic aspect.

\section{Rezumat}

Deși lingvistica, știință a limbii, a ajuns în prezent la un nivel înalt de dezvoltare, totuși în domeniul sintaxei mai rămân încă multe probleme nesoluționate îndeajuns. Una dintre ele, foarte importantă, este cea a criteriului de determinare a părților de propoziție. Astfel, din cauza aplicării inconsecvente a principiilor, la analiza faptelor de limbă, la nivel sintactic, se ajunge uneori în extrema formalismului structural-gramatical, prin
\end{abstract}


care, drept rezultat, sunt suprapuse părțile de propoziție cu părțile de vorbire, ceea ce conduce spre o morfologizare a sintaxei. O atare analiză sintactică este fără de folos, deoarece face imposibilă identificarea reală a gândurilor din text.

Grămătiștii, situați pe poziții morfologiste în sintaxă, lansează diferite variante metodologice în acest sens. Una dintre ele ar fi cea prin care se susține că forma gramaticală de caz al cuvântului ar fi decisivă la identificarea părților de propoziție. O astfel de metodă este mai puțin aplicabilă în limba română, deoarece la aceeași formă gramaticală de caz avem mai multe funcții sintactice și la aceeași funcție - mai multe forme.

Aceste aspecte morfologice și sintactice încercăm să le analizăm prin demonstrare în studiul ce urmează, referindu-ne, în special, la statutul semantico-sintactic al subiectului logic în propoziție.

Cuvinte-cheie: principiu logic și semantic, formalism structural-gramatical, morfologizare a sintaxei, sintaxa formală, aspect pragmatic, aspect sintagmatic etc.

Se știe că la analiza faptelor de limbă, conform criteriilor metodologice ale sintaxei funcționale, „referința la caracteristicile de ordin semantic, pertinente sub aspect pragmatic și sintagmatic, nu poate fi diminuată și nici omisă", fiindcă, la o atare procedură lingvistică, drept rezultat, „obținem, pe de o parte, o sintaxă semantică și, pe de altă parte, o semantică sintactică, împreună evoluând într-un corolar al interdependenței dintre planul conținutului și cel al expresiei" (Diaconescu, 1989, p. 110). Astfel, în cadrul general al gramaticii, sintaxa și semantica se află într-o permanentă corelație, de care, fiind indisolubil legate, nu se separă. „În acest fel, susține Eugen Coșeriu, nu e bine să distingem între sintaxă și gramatică, deoarece, într-un anumit sens, tot ce este gramatică în limbă este și sintaxă” (Coșeriu, 1994, p. 65). Această observație ne obligă să sesizăm corect simbioza raporturilor dintre gramatică și sintaxă, dat fiind faptul că numai în așa mod vom putea determina mai exact locul și rolul fiecărei unități comunicative în sistemul ei morfologic și sintactic.

Sintaxa semantică sau funcțională însă se află în opoziție cu sintaxa structuralformală, deoarece aceasta din urmă, dând prioritate formei gramaticale a cuvântului în orice propoziție, face abstracție de semantică, absolutizând ideea conform căreia „două lexeme, deosebite ca sens, pot fi determinate și pe baza diferențelor de forme gramaticale, cu ajutorul comutației și distribuției”. (Diaconescu, 1989, p. 40) Este bine știut că morfologia creează formele structurale ale cuvintelor, iar sintaxa le definitivează prin sistemul ei de funcționare comunicativ-informativă, ceea ce face ca sintaxa să devină „,veritabilă paradigmatică a semnificațiilor gramaticale”. (ibidem) În așa fel, datorită parametrilor sintaxei funcționale, dat fiind că tot ce ține de gramatică are și un sens comunicativ, ,,putem determina în cadrul propoziției, de rând cu semantica informativă, și sistemul structural-gramatical al constituenților ei" (ibidem).

Sintaxa funcțională se opune gramaticii structurale, deoarece nu-și are, ca scop în sine, forma gramaticală a unităților ei comunicative, ci doar le determină posibilităţile structurale, care, de fapt, stimulează procesul studierii semnificațiilor sau a conținuturilor informativ-comunicative ale 


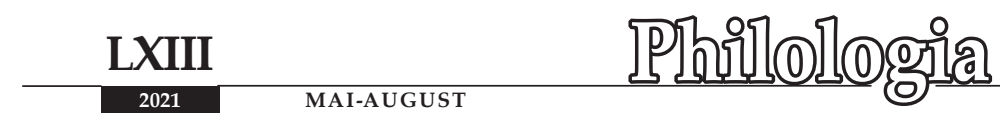

lexemelor așa cum sunt ele concret structurate într-o limbă. Prin structură, „sintaxa functională subînțelege specificul relațiilor interne sub orice aspect comunicativ al cuvântului în propoziție, deoarece, la nivel sintactic, felul acestor raporturi constă în opozițiile care se stabilesc între unitătile lexicale" (Coșeriu, 1994, p. 83).

Organizarea unităților lexicale într-un enunț, conform principiilor semantice ale sintaxei funcționale, alcătuiește, de fapt, baza organizării structurale a unităților sintactice, încât un model sau o schemă semantică determină, în cele mai frecvente cazuri, schema sau modelul sintactic, după cum schema sau modelul sintactic, prin varietatea posibilităților de organizare structurală, actualizează unitățile semanticecomunicative în orice context. Datorită acestor corelații, când schema sau modelul coincid, planul semantic devine convergent cu planul sintactic" (Diaconescu, 1989, p. 126).

De aceste teze teoretice e necesar să se tină cont sistematic la analiza sintactică a părților de propoziție, încât factorul logic și semantic să fie în permanență primordial. Din acest punct de vedere, trebuie ca, în orice enunț, să se precizeze mai întâi sensul informativ al cuvântului cu relevanță comunicativă (sintactică), întrucât numai după o atare procedură s-ar putea determina real valoarea semantico-functională a fiecărui cuvânt în propoziție; cât despre identificarea formei gramaticale de exprimare, categoric, trebuie să alcătuiască cea din urmă etapă a analizei.

Considerăm că anume ignorarea factorului semantic la delimitarea subiectului logic în propoziție a făcut vădit ostentativă reproșabila tendință de a suprapune în mare măsură categoriile sintactice cu cele morfologice, fapt care nu poate fi tăgăduit/ combătut chiar și după felul cum este prezentată respectiva parte de propoziție în mai multe lucrări de gramatică: monografii, manuale, studii, articole etc. Interpretările nesemantice creează uneori impresia că subiectul în orice propoziție nu este altceva decât doar un cuvânt (substantiv sau pronume) la cazul nominativ, care răspunde la întrebările cine? ce? O atare definire a subiectului ne orientează către o analiză formal-structurală, de obicei morfologistă, ce consistă doar din dezmembrarea elementelor constituente ale structurilor sintactice cu funcție de subiect (a se vedea: Popescu, 1995, p. 443).

Eroarea analizei date este și mai evidentă atunci când functịa de subiect este realizată de o îmbinare de cuvinte alcătuită din două sau mai multe lexeme cu sens informativ unitar. Din cauza unei atare tratări morfologiste a subiectului logic dezvoltat, drept urmare, se produce fenomenul suprapunerii părților de propoziție cu părțile de vorbire, ceea ce face ca și categoriile sintactice să rămână categorii morfologice, astfel generând variate ambiguităti.

Spiritul formalist la analiza sintactică a faptelor de limbă a creat situația în care, la identificarea subiectului propoziției se susține, cu tot seriosul, că, în propoziții de tipul Omul neînvățat este ca un copac neîngrijit, substantivul „Omul” este subiect simplu, de sine stătător, iar adjectivul „neînvățat” ar fi, chipurile, un vădit atribut acordat (a se vedea: Cartaleanu, Ciobanu, 2018, p. 176). O astfel de viziune este în conformitate cu tendințele generale de a segmenta unităţile semantico-sintactice după componența structurală. Se face oarecum totul pentru a dizolva sintaxa în 
morfologie, de vreme ce analiza sintactică începe nu de la sensul informativ, dar de la forma gramaticală a cuvântului.

Trebuie totuși să punem la bază principiile sintaxei funcționale, prin care vom promova o analiză ce ar ține de realitatea gândului scontat de vorbitor și perceput corect de ascultător. În temeiul principiilor funcționaliste, în enunțul Omul neînvățtat este ca un copac neîngrijit, rolul de subiect îl îndeplinește nu numai substantivul „omul”, ci întreaga îmbinare de cuvinte „omul neînvățat”, deoarece anume acest bloc alcătuiește un tot întreg logic, semantic și intonațional. Numai substantivul cu adjectivul împreună răspund la întrebarea subiectului judecății, care este real în enunț: Despre cine se vorbește în propoziție? - despre „omul neînvățat”, Ce se spune despre subiectul ,omul neînvățat”? - este ca un copac neîngrijit (ceea ce înseamnă că este inferior din punct de vedere moral și intelectual). Luarea în bloc sintactic a subiectului logic „omul neînvățat” este cerută și de semantica informativă a predicatului nominal dezvoltat (este ca un copac neîngrijit), fapt susținut și de valoarea proverbială (metaforică) a enunțului, prin care se face, pe de o parte, o replică la adresa necărturăriei unora, iar, pe de altă parte, este și un apel la o cultivare intelectuală prin învățământ; de fapt, avem aceeași morală a proverbului: Cine știe carte are patru ochi.

Prin urmare, viziunea semantică la identificarea subiectului în propoziție face loc onorabil logicii reale, naturale, ceea ce are și o deosebită importanță la analiza, predarea și cercetarea problemelor de sintaxă. Părțile principale ale propoziției, în raport cu părțile secundare, sunt categorii functionale, conditionate, în primul rând, de poziția lor semantico-funcțională. Subiectul și predicatul formează unități sintactice propoziționale oarecum independente gramatical, ce se intercondiţionează. Prin statutul lor sintactic, regentează subordonarea părților secundare, iar, datorită conținutului predicativ pe care îl dețin împreună, alcătuiesc sintagma principală, sintagma numărul unu în orice enunț; tot în temeiul categoriei predicativitătiii, subiectul și predicatul propoziției se află în raport de inerență unul față de altul (Banaru, 1973, p. 34).

Asemeni tuturor părților de propoziție, subiectul și predicatul se exprimă prin părți de vorbire, cu care, în general, nu se suprapun, ceea ce înseamnă că nu toate substantivele pot fi subiecte numai pentru că au forma gramaticală a cazului nominativ, dar nici toate verbele nu pot forma de sine stătător predicatul. O dovadă în acest sens este faptul că chiar una și aceeași parte de vorbire, în funcție de relațiile ce apar pe axa sintagmatică, poate îndeplini mai multe funcții sintactice. De exemplu, substantivul cu prepoziție „de jale” cumulează nu numai o singură funcție sintactică, dar, în dependență de context, mult mai multe: 1) de complement circumstanțial cauzal: De jale plânge tata,/ De jale plâng și eu. (V. Romanciuc); 2) de complement indirect: La noi de jale povestesc / A codrilor desișuri..., (O. Goga); 3) de subiect: „De jale” este un substantiv cu prepoziție.; 4) de atribut: Cântecele de jale le ascultau cu tristețe în suflet. (Tudor Colac).

Respectivele situații sintactice argumentează ideea că, la identificarea subiectului logic în propoziție, e necesar să luăm ca bază criteriul semantic al sintaxei funcționale, în caz contrar nu vom pătrunde în interiorul unităţilor sintactice, unele rămânând a fi ireale. Principiul logico-semantic ne sugerează să definim subiectul 


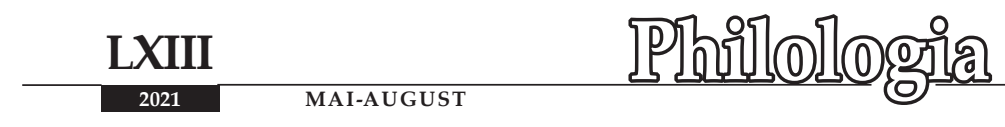

drept parte principală care exprimă agentul acțiunii, stării și existenței în propoziție și care răspunde la întrebările despre cine sau despre ce se vorbește în propoziție? (acestea sunt întrebările preluate din logică, știință a gândirii, din care a provenit sintaxa, ca nivel ce reprezintă limba sub aspect comunicativ); numai subiectul logic are tangențe directe cu structura judecății (Ciobanu, 1987, p. 86-89).

Grație acestui concept, funcția de subiect logic în propoziția Casa fără femeie este ca o biserică devastată o îndeplinește îmbinarea subliniată casa fără femeie (Despre cine se vorbește în propoziție? - despre casa fără femeie; Ce se spune despre subiectul casa fără femeie? - este ca o biserică devastată). Drept argument al adevărului științific despre relevanța sintactică a unităților acestei propoziții servește și faptul că niciun element component din ambele blocuri sintactice nu poate fi omis sau convertit în altă parte de propoziție, întrucât ar duce la denaturarea semantico-sintactică a enunţului, în general. De aceea, considerăm că anume metoda de analiză în spiritul sintaxei funcționale este reală și cu folos, întrucât alcătuiește o expresie a logicii reale și imanente a gândurilor din orice enunț.

Întrebările cine? ce? sunt incompatibile cu metodologia de identificare a subiectului logic, deoarece implică stricte aspecte morfologice. Prin întrebarea $c e$ ? sau ce face? putem identifica doar un subiect și un predicat fals, ireal: ce? casa ... ce face? - este. Mai mult decât atât, predicatul ar deveni unul nemotivat, odată ce verbul ,,a fi” este unul copulativ, lipsit de valoare predicativă. Aceasta ar însemna că, efectuând analiza sintactică în spirit morfologist, putem, în general, denatura valorile comunicativ-informative (sintactice) reale. Această unitate sintactică propozițională mai comportă și o valoare proverbială/ metaforică, ceea ce face inadmisibilă dezmembrarea blocului sintactic al subiectului (casa fără femeie) și al predicatului (este ca o biserică devastată).

Tot în spirit morfologist este determinat și subiectul propoziției în situațiile sintactice în care se ia drept bază metodologică forma gramaticală de caz a cuvântului, făcându-se abstracție atât de sensul lui informativ, cât și de raportul morfologic și sintactic (a se vedea: Mătcaș, 1982, p. 78-103). Potrivit unui atare concept, cuvintele subliniate din propozițiile: 1) Mie mi s-a întâmplat un caz.; 2) Când nouă ni-i dor.; 3) Pe Hartene nu-l tăia capul... nu sunt considerate subiecte logice și gramaticale numai pentru că nu au forma gramaticală a cazului nominativ. Drept subiecte sunt luate cuvintele: (1) un caz (Un caz s-a întâmplat mie, mi); (2) dor (Când dor este nouă, ni); (3) capul (Capul nu tăia pe Hartene). Atare subiecte nu sunt motivate sintactic, prin ele doar se denaturează informația generală a propozițiilor. Fiind calificate drept subiecte, ele formează vădite aberații, în pofida faptului că în primele două exemple, evident, este vorba despre starea sufletească a agenților concreți, anunțați prin formele gramaticale ale pronumelor personale la cazul dativ mie, nouă: (1) (Mie) Eu am fost în starea unei asemenea situații sau caz; (2) Când (nouă) noi suntem în stare de dor, copleșiți de dor; în exemplul (3) este vorba despre o acțiune: Hartene nu se putea gândi sau aștepta la una ca asta. În situația acestui de-al treilea exemplu, funcția sintactică de subiect logic și gramatical este îndeplinită de substantivul cu prepoziție „Pe Hartene”, aflat la cazul acuzativ). De fapt, acestea sunt gândurile reale, enunțate de vorbitor 
și percepute de ascultător (dacă am observat, în ex. (3), analiza morfologistă chiar profanează într-un fel valoarea semantico-sintactică a propoziției: Capul nu tăia pe Hartene?).

Așadar, forma gramaticală de caz pentru identificarea subiectului logic în propoziție este ireală și lipsită de relevanță. Categoria gramaticală a cazului nu este o condiție strictă în astfel de situații, întrucât subiectului, în raport cu predicatul, i se cere doar să se acorde în persoană și număr, în situațiile sintactice ale predicatelor verbale, și în gen, număr și persoană, în cele ale predicatelor nominale. Forma gramaticală a cuvântului, aflat în raport gramatical cazual, nu poate fi utilizată în exclusivitate, deoarece în limba română, pentru fiecare valoare a semnificatului cazual, nu dispunem de forme specifice, ca în limba latină, unde cazurile erau ușor delimitate prin desinențe. În limba română s-au format omonimii prin reducerea desinențelor latine și prin fenomenul de sincretism, iar, drept consecință, specificul structural-gramatical s-a diminuat, ceea ce ne-a făcut să conchidem că problema categoriei gramaticale a cazului în limba română, pe cât este de complicată, pe atât este și de simplă: complicată, deoarece nu pot fi definite și determinate formele de bază inițiale, și simplă, doar dacă se susține opinia despre permanenta corelație dintre formă și conținut (Diaconescu, 1989, p. 112).

În limba română, forma gramaticală de caz nu-și are rolul principal la determinarea funcțiilor sintactice. De aceea, privită din punct de vedere logicosemantic, forma cuvintelor evidențiate prin subliniere din exemplul Ai casei se adunau în jurul lui Onache (I. Druță) nu mai este una de genitiv propriu-zis, ci un echivalent functional al nominativului. Substantivul cu articol ai casei este perceput ca un cuvânt de sine stătător, ca un determinat, și nu ca un determinant. Acest substantiv cu articol îndeplinește funcția de subiect logic și gramatical: despre cine este vorba în propoziție? - despre ai casei; ce se spune despre subiectul ai casei? - se adunau.

Și din punct de vedere structural-gramatical este justificată poziția sintactică de subiect a substantivului cu articol ai casei, deoarece este cerută de forma gramaticală a verbului-predicat, la numărul plural, persoana a III-a: Ai casei se adunau în jurul lui Onachi, dar nu Ai casei se aduna în jurul lui Onachi.

Respectiva formă gramaticală de genitiv poate cumula nu numai funcția de subiect, dar și cea de complement indirect (Am transmis multă sănătate cui? la ai casei); de complement direct (Eu i-am găsit pe cine? pe ai casei în câmp); de nume predicativ al predicatului nominal (Ei sunt ai casei și îmi sunt tare dragi) etc.

Menționăm că subiectul logic și gramatical în limba română poate să se exprime și prin celelalte forme cazuale: a) cazul dativ (Călătorului îi șade bine cu drumul); b) cazul acuzativ (Pe badea Ion îl cheamă); ambele subiecte exprimă agentul logic al predicatului.

Așadar, în limba română, forma gramaticală de caz, pentru identificarea subiectului logic, nu poate fi o condiție strict necesară și nici nu poate fi utilizată în exclusivitate. Forma gramaticală a cuvântului, aflată în raport gramatical cazual, nu este primordială, odată ce agentul acțiunii sau stării poate fi anunțat prin orice altă formă de caz, decât numai cea de nominativ (A se vedea „Nota” din subsol!). Spre exemplu, în enunțul Mie trei litere-mi plac. (Gr. Vieru), pronumele personal 


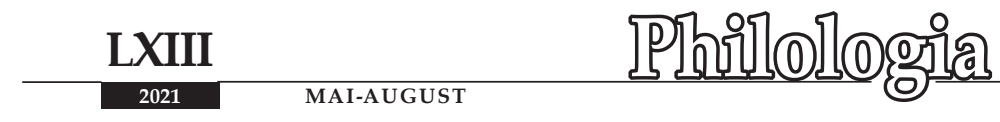

mie, deși este la cazul dativ, exprimă excelent agentul stării și se acordă în număr și persoană cu predicatul (pers. I, sg), îndeplinind funcția sintactică de subiect logic. Forma gramaticală este la cazul dativ, caz oblic, confirmat de regimul structural al verbului care i se subordonează. Aplicând criteriul semantic al sintaxei funcționale, am constatat că funcția de subiect logic este îndeplinită de pronumele personal mie, la cazul dativ: Mie imi plac trei litere. - Eu sunt îndrăgostit de trei litere. sau $\boldsymbol{E} \boldsymbol{u}$ am o plăcere aparte față de aceste trei litere din alfabet. ${ }^{1}$

Pe baza celor analizate până acum, susținem că identificarea și definirea subiectului logic în propoziție constituie un proces complex, în ale cărui mecanisme sunt angajate aspectele generale și esențiale ale tuturor compartimentelor limbii, dar ceea ce reunește părțile de vorbire cu părțile de propoziție este planul sintactic, unde calitatea unităţilor morfologice devine relevantă pentru poziția sintactică de determinat sau determinant. La nivel sintactic, o parte de vorbire, căpătând relevanță comunicativă, își obține rolul și locul ei în sistemul morfologic și sintactic al propoziției și numai ținând cont de specificul fiecăreia, putem determina valorile ei sintactice reale (Ciobanu, 1987, p. 88-89).

Datorită fuziunii organice dintre categoriile morfologice și cele sintactice, multe aspecte, privind identificarea subiectului logic și gramatical, devin dificile. Pentru a depăși aceste bariere, e necesar doar să se conștientizeze că subiectul logic exprimă agentul acțiunii sau stării în propoziție, iar subiectul gramatical se acordă cu predicatul în număr și persoană, dacă este predicat verbal, și în gen număr și persoană, cu cel nominal. Subiectul logic și gramatical nu se manifestă separat, ci simultan, unul prin altul, alcătuind o situație de idem per idem, deși sunt noțiuni care diferă.

Subiectul gramatical dispune de o singură situație sintactică, în care se manifestă separat de subiectul logic, și anume atunci când verbul-predicat este la diateza pasivă, iar, drept rezultat, subiectul logic devine complement de agent: Florile sunt udate de elevi (această formă provine din cea activă - Elevii udă florile).

În încheiere, susţinem că, la definirea și identificarea subiectului logic în propoziţie, este necesar să se țină cont în permanență de relevanța sintactică a cuvântului, dacă are valoare de agent al acțiunii sau stării. Totodată, să se ia în calcul și semnificația relațiilor pe care le contactează cu alte logoforme. Conținutul comunicativ-informativ este definitoriu, dacă este determinat în temeiul întrebărilor corecte din punct de vedere logic și semantic. Cu întrebări morfologice, ale formei structurale, de multe ori putem doar denatura sensul informativ-comunicativ al subiectului logic.

${ }^{1}$ A. A. Potebnea, având la început unele îndoieli cu privire la categoria gramaticală a cazului, îndeosebi cu referire la granițele dintre cazuri, a demonstrat până la urmă complicata corelație dintre sensul general al semnificațiilor cazului și al varietăților lui funcționale. Mai târziu, pe baza tezelor potebniene, profesorul moscovit R. A. Budagov deduce ceea ce caracterizează cu adevărat această categorie gramaticală: „Cazul, din punct de vedere gramatical, este o categorie morfologică, iar, din punct de vedere funcțional, o categorie sintactică.” A se vedea: A. A. Potebnea, Iz zapisok po russkoi grammatike. Moscova: Nauka, 1958, p. 67-68; R. A. Budagov, Shodstva i neshodstva mejdu rodstvennîmi iazîkami. Moscova: Nauka, 1985, p. 39. 


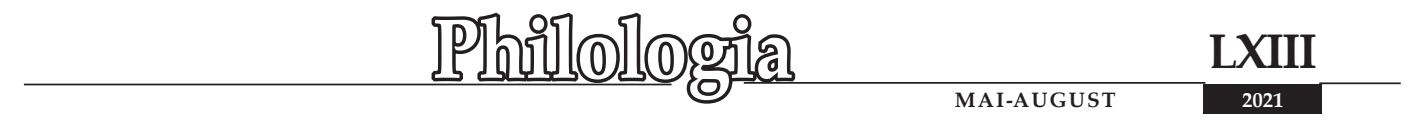

\section{Referințe bibliografice:}

BANARU, Victor. Ocerk po teorii predikativnosti. Chișinău: Știința, 1973.

CARTALEANU T., CIOBANU, M., COSOVAN, O. Limba și literatura română, clasa a VII-a. Chișinău: Știința, 2018.

CIOBANU, Anatol. Sintaxa și semantica. Chișinău: Știința, 1987.

COȘERIU, Eugen. Prelegeri și conferințe (1992-1993). Iași, 1994.

DIACONESCU, Ion. Probleme de sintaxă a limbii române actuale. București: Editura Științifică și Enciclopedică, 1989.

MẢ TCASS, Nicolae. Școală a gândului. Chișinău: Lumina, 1982.

POPESCU, Ștefania. Gramatica practică a limbii române. București: Editura Orizonturi, 1995.

Notă: Articolul a fost realizat în cadrul proiectului de cercetare 20.80009.1606.01 Valorificarea științifică a patrimoniului lingvistic național în contextul integrării europene, Institutul de Filologie Română „B. P.-Hasdeu” al MECC. 


\title{
STUDIU LINGVISTIC ASUPRA MANUSCRISULUI „SANDIPA" MORFOLOGIA (3.2.). PRONUMELE
}

\author{
GaLACTION VEREBCEANU
}

Doctor în filologie, conferențiar cercetător

E-mail: gverebceanu@gmail.com

ORCID: https://orcid.org/0000-0002-0725-4893

Institutul de Filologie Română „Bogdan Petriceicu-Hasdeu” (Chişinău)

\section{Linguistic Study on the „Sandipa” Manuscript. Morphology (3.2.). Pronouns}

\begin{abstract}
The morphological peculiarities of the pronoun present in the text of the popular writing entitled Sandipa (ms. Rom. 824, dated in 1798 and kept at the State Library of the Russian Federation, Moscow) are analyzed. Being a flexible part of speech with several species (9), the pronoun is highlighted by a series of forms typical of both our first ancient texts and those developed in the second half of the eighteenth century, especially in recent decades. of the century, therefore contemporary with the handwritten version of the popular writing announced in the title.

Keywords: pronominal adjective, case, form, gender, personal pronoun, politeness pronoun, reinforcement pronoun, reflexive pronoun, possessive pronoun, demonstrative pronoun, Relative pronouns, indefinite pronouns, negative pronouns.

\section{Rezumat}

Sunt analizate particularitățile morfologice ale pronumelui prezente în textul scrierii populare intitulate Sandipa (ms. rom. 824, datat în 1798 și păstrat la Biblioteca de Stat a Federației Ruse, Moscova). Fiind o parte de vorbire flexibilă cu mai multe specii (9), pronumele se evidențiază printr-un șir de forme proprii atât primelor noastre texte vechi, cât și celor elaborate în a doua jumătate a secolului al XVIII-lea, în special în ultimele decenii ale secolului, așadar contemporane cu varianta manuscrisă a scrierii populare anunțate în titlu.

Cuvinte-cheie: adjectiv pronominal, caz, formă, gen, pronume personal, pronume de politețe, pronume de întărire, pronume reflexiv, pronume posesiv, pronume demonstrativ, pronume relativ, pronume nehotărât, pronume negativ.

Într-un articol publicat recent în revista „Philologia” (vezi Verebceanu, 2021, p. 75-84), a fost examinată morfologia unor părți de vorbire flexibile prezente în

${ }^{1}$ Vezi Verebceanu, 2017, p. 35-55; 67-89; 113-130; Verebceanu, 2019, p. 49-63; Verebceanu, 2020a, p. 93-102; Verebceanu, 2020b, p. 22-36; Verebceanu, 2021, p. 75-84.
\end{abstract}


textul scrierii populare anunțate în titlu (ms. rom. 824, datat în 1798 și păstrat la Biblioteca de Stat a Federației Ruse, Moscova). Scopul articolului de mai jos este cercetarea particularităților morfologice ale pronumelui, parte de vorbire flexibilă cu mai multe specii care se evidențiază printr-un șir de forme proprii atât primelor noastre texte vechi, cât și celor elaborate în a doua jumătate a secolului al XVIII-lea, în special în ultimele decenii ale secolului, așadar contemporane cu varianta manuscrisă a romanului popular.

Pronumele, în calitate de clasă de cuvinte lexico-gramaticală cu trăsături oarecum distinctive faţă de celelalte părți de vorbire flexibile analizate, are, în general, aceeași structură ca și în limba literară de astăzi. Există totuși unele caracteristici care merită atenție.

Pronumele personal propriu-zis posedă o paradigmă, cu unele diferențe de ordin fonetic, asemănătoare cu cea din româna actuală. Dăm în continuare formele flexionare consemnate în text.

Persoana 1 singular nominativ masculin, feminin: $e u\left(2^{\mathrm{v}}, 9^{\mathrm{r}}\right)$; dativ: mie $\left(69^{\mathrm{v}}\right.$, $8^{\mathrm{r}}$ ), miia $^{2}$ (= mie, numai masculin, $34^{\mathrm{r}}, 98^{\mathrm{r}}$ ), îm (doar cu $m$ suprascris, $100^{\mathrm{v}}, 8^{\mathrm{r}}$ ), -mi (numai masculin, 92 $2^{\mathrm{v}}$ ), me- (= mi, masculin, $15^{\mathrm{v}}, 19^{\mathrm{r}}, 63^{\mathrm{v}}, 65^{\mathrm{r}}, 86^{\mathrm{v}}-2,90^{\mathrm{r}}$; feminin, $\left.64^{\mathrm{v}}, 65^{\mathrm{r}}, 81^{\mathrm{v}}\right)$, -m (doar suprascris, $\left.7^{\mathrm{r}}, 82^{\mathrm{v}}\right)$; acuzativ: (pe) mine $\left(32^{\mathrm{r}}, 10^{\mathrm{r}}\right)$, mă $\left(32^{\mathrm{v}}\right.$, $\left.83^{\mathrm{v}}\right),-m a \breve{a}\left(14^{\mathrm{r}}, 94^{\mathrm{r}}\right)$.

Persoana a 2-a singular nominativ masculin, feminin: $t u\left(6^{v}, 9^{v}\right)$; dativ: ție $\left(79^{\mathrm{v}}, 71^{\mathrm{v}}\right)$, țiia $^{2}$ (= ție, numai masculin, $\left.57^{\mathrm{r}}, 90^{\mathrm{r}}\right)$, ît (doar cu ț suprascris, $\left.54^{\mathrm{r}}, 36^{\mathrm{r}}\right)$,

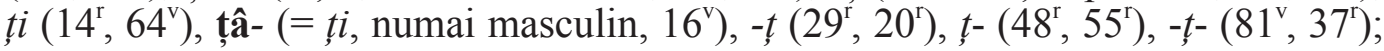
acuzativ: (pe) tine (numai masculin, $\left.41^{\mathrm{r}}\right)$, te $\left(5^{\mathrm{r}}, 25^{\mathrm{v}}\right)$, -te $\left(28^{\mathrm{v}}, 38^{\mathrm{r}}\right)$, te- $\left(40^{\mathrm{r}}, 49^{\mathrm{v}}\right)$.

Persoana a 3-a singular nominativ masculin: el $\left(15^{\mathrm{D}}\right)$, elu $\left(99^{\mathrm{v}}\right)$; feminin: ea $\left(58^{\mathrm{r}}\right)$, e $\left(=e a, 66^{\mathrm{r}}\right)$; genitiv-dativ: lui $\left(90^{\mathrm{r}}, 1^{\mathrm{v}}\right)$; ei $\left(15^{\mathrm{r}}, 35^{\mathrm{v}}\right)$; dativ: $\hat{\imath i}\left(72^{\mathrm{r}}, 42^{\mathrm{r}}\right), i\left(90^{\mathrm{r}}\right.$, $\left.37^{\mathrm{v}}\right),-i\left(39^{\mathrm{r}}, 46^{\mathrm{v}}\right), i-\left(1^{\mathrm{v}}, 62^{\mathrm{v}}\right),-i-$ lipsește; acuzativ: (pe) el lipsește; $\hat{l} l\left(3^{\mathrm{r}}\right),-l\left(31^{\mathrm{r}}\right)$, l- $\left(64^{\mathrm{r}}\right)$, le $\left(=\hat{\imath} l, 89^{\mathrm{v}}\right)$, li $\left(=\hat{\imath} l, 41^{\mathrm{r}}, 45^{\mathrm{v}}\right)$, (pe) dânsul (81 $)$, intr-însul $\left(65^{\mathrm{v}}\right)$; (pe) ea lipsește; $o\left(18^{\mathrm{r}}\right),-o\left(22^{\mathrm{v}}\right)$, (pe) dânsa $\left(74^{\mathrm{r}}\right)$, într-însa $\left(88^{\mathrm{r}}\right)$.

Persoana 1 plural nominativ: noi $\left(12^{\mathrm{v}}\right)$; genitiv-dativ: nouă lipsește; dativ: ne

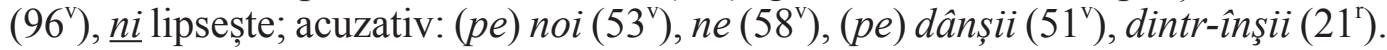

Persoana a 2-a plural nominativ: voi $\left(7^{\mathrm{r}}\right)$; dativ: voao $\left(=\right.$ vouă $\left., 7^{\mathrm{v}}, 70^{\mathrm{r}}, 83^{\mathrm{r}}\right)$; acuzativ: (pe) voi lipsește; vă $\left(75^{\mathrm{r}}\right)$.

Persoana a 3-a plural nominativ masculin: ei $\left(12^{\mathrm{r}}\right)$; feminin: ele lipsește; genitiv: $\operatorname{lor}\left(57^{\mathrm{r}}, 48^{\mathrm{r}}\right)$; dativ: lor lipsește; le $\left(4^{\mathrm{r}}, 8^{\mathrm{v}}\right)$, li $\left(76^{\mathrm{v}}\right)$; acuzativ: (pe) ei lipsește, î $\left(48^{\mathrm{r}}\right)$, le $\left(56^{\mathrm{r}}\right)$, li- $\left(=\right.$ le, $\left.67^{\mathrm{r}}\right)$; $($ pe $)$ ele lipsește, le $\left(56^{\mathrm{r}}\right),\left(\right.$ pe) dânsăle $\left(51^{\mathrm{r}}\right)$, dintrinsăle $\left(61^{\mathrm{v}}\right)$.

Din prezentarea de mai sus a formelor flexionare consemnate în textul manuscrisului Sandipa rezultă faptul că: a) la unele persoane se constată lipsa formelor accentuate și neaccentuate (marcate prin subliniere); b) pronumele de

${ }^{2}$ Formele miia și țiia erau răspândite în textele şi documentele din secolul al XVI-lea (vezi Densusianu, 1961, p. 116-117). Vezi, de asemenea, interpretarea lui Al. Rosetti despre unul din fonetismele în discuție: „miia apare în textele lui Petru Șchiopul $<\ldots .>$; astăzi forma aceasta este curentă în graiul moldovenesc (mie + amplificativul $a$, pornind de la construcții ca: mie unuia > mia" (Rosetti, 1978, p. 556). 


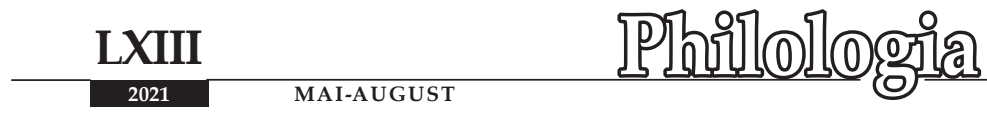

persoana a 3-a, masculin și feminin, nu cunosc cazul acuzativ; c) locul acestora este ocupat de formele pronumelui dânsul, ca sinonim al lui el, deci nu ca pronume de politețe cum apare astăzi în limba literară, însoțit totdeauna de un număr variat de prepoziții, și de îns, folosit articulat și în îmbinare cu prepozițiile întru și dintru; d) sunt înregistrate forme arhaizante folosite exclusiv pentru masculin (marcate cu aldin), respinse însă astăzi de aspectul normat al limbii literare: „Miia mi-i milă de tine” (34'), ,omule, ci me-i furat ochiul meu” $\left(86^{v}\right)$, ,să nu să întâmple ceva rău mie sau ţiia" $\left(57^{7}\right)$, ,nu vei pute scăpa de dânsul şi cu greu le-i împăca” $\left(89^{v}\right)$, ,tu ţine-t pământul carile ţi s-au dat şi ţâ-1 lucrează” $\left(16^{\vee}\right)$, ,pre carile sângur împărăţie ta de atâte ori ai zis că $l i$-i omorî” $\left(41^{1}\right)$, „nici să zici că $l i$-i birui pe muieri” $\left(67^{1}\right)$, ,Ci vi să pare voao tăcere aceasta a cuconului?" $\left(7^{\vee}\right)$.

Formele neaccentuate, clitice, de dativ și acuzativ, precedate de cele mai multe ori de cuvinte monosilabice terminate în vocală, așa-numitele cuvinte atone, sunt notate, de obicei, fără $\hat{\imath}$ - protetic: ,a- $i$ arăta” $\left(4^{\mathrm{r}}\right)$, ,nu- $i$ spusă” $\left(46^{v}\right)$, ,,să- $i$ dau” (64 $)$

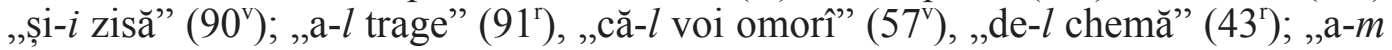

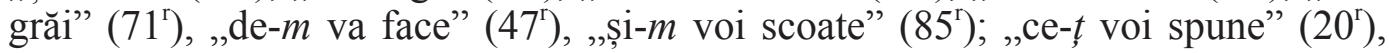
„să- $t$ s spuiu" $\left(70^{r}\right)$ etc. Mai rar, formele în discuție apar în vecinătatea cuvintelor polisilabice: ,orice-i poronce” $\left(43^{\ulcorner}\right)$, ,cându- $m$ spune" $\left(8^{v}\right)$, ,vinde- $m$ ” $\left(45^{\vee}\right)$, ,ţine- $t^{\prime}$ $\left(16^{v}\right)$ etc.

Unele forme clitice conjuncte au o întrebuințare particulară, fiind plasate după

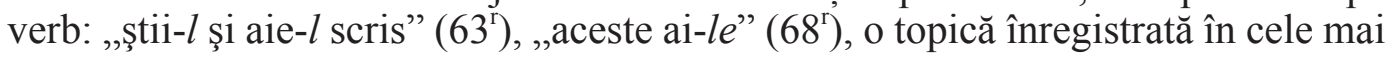
vechi texte (vezi Densusianu, 1961, p. 117; vezi și Mareș, 1969, p. 76; Chivu, 1993, p. 180) sau în prepoziția verbului la perfectul compus, în această poziție se remarcă pronumele personal de persoana a 3 -a feminin singular acuzativ $o$ : „Şi aşe să pricie ficiorul împăratului cu ace fimeie și $o$ au rămas-o şi $o$ au dovedit” $\left(33^{r}\right)$, ,eu nu $o$ am lăsat-o" $\left(37^{v}\right)$, asemenea constructii întâlnindu-se în textele din secolul al XVI-lea (vezi, de exemplu, Rosetti, 1978, p. 558; Buză, Zgraon, 1982, p. 511; Georgescu, 1982, p. 400).

Procedeul contragerii celor două vocale alăturate este concurat de procliza lui $\hat{\imath}$, exemplele consemnate având o frecvență totuși mai puțin numeroasă în raport cu formele etimologice: ,,il dedi” $\left(30^{\mathrm{r}}\right)$, , ,î făcură” $\left(96^{\vee}\right)$, , ,il ieşi” $\left(84^{\vee}\right) ;, \hat{l} l$ dusă” $\left(8^{\vee}\right)$,

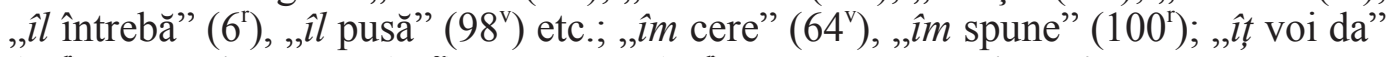
$\left(36^{\mathrm{r}}\right)$, , , it mulțemesc" $\left(47^{\mathrm{v}}\right)$, , , iț spun" $\left(86^{\mathrm{r}}\right)$ etc. Fenomenul câștigă teren în epocă „în toate variantele literare, fiind atestate de texte din toate regiunile" (ILRL, 1997, p. 328).

O altă particularitate a formelor neaccentuate de dativ și acuzativ este implicarea acestora la anticiparea sau reluarea complementului direct şi indirect (acest fenomen va fi examinat în capitolul de sintaxă).

Pronumele de politețe - subclasă de pronume personale - înregistrează, ca text și frecvență, un număr neînsemnat de forme. Din sistemul de marcare a reverenței fac parte: dumneta $\left(17^{\mathrm{v}}, 37^{\mathrm{v}}, 45^{\mathrm{v}}, 48^{\mathrm{r}}-2\right)$, dumnata $\left(38^{\mathrm{r}}, 38^{\mathrm{v}}, 87^{\mathrm{v}}, 88^{\mathrm{v}}, 90^{\mathrm{r}}-\right.$ 2) pentru persoana a 2-a singular nominativ-acuzativ, ambele cu structură fonetică învechită, dumitale $\left(45^{\mathrm{v}}, 49^{\mathrm{r}}, 84^{\mathrm{v}}\right)$ pentru genitiv-dativ și locuțiunea pronominală Măria Ta, având ca bază de formare substantivul învechit mărie: ,el mă sfătui şi mă învăţă cum să grăiescu înainte Mării<i> Tale" $\left(83^{\vee}\right)$. 
Pronumele de întărire. În lipsa formei însumi, funcția de pronume de întărire este preluată de sinonimul adjectival singur, notat în text cu vocală velară, care apare în vecinătatea unui pronume personal: „tu sângur m-ai supus la alţii” $\left(35^{\mathrm{r}}\right)$, ,,acum ai venit tu sângur” (79 $)$, ,rămasă el sângur” $\left(55^{\prime}\right)$, „să face el sângur pre sine înţelept” $\left(74^{\vee}\right)$, „mai bine să mă omor eu sângură" $\left(58^{\mathrm{r}}\right)$, ,eu sângură mă voi omorî” (33 $\left.3^{v}\right)$, „să saie ea sângură în focu să arză” $\left(58^{\mathrm{r}}\right)$, „, ,e vreme sânguri voi mărturisiţ̧" $\left(83^{\text {r }}\right.$ sau a unui pronume relativ: „,ă aştepte să-l laude alţii, iar nu sângur ciniva să să laude” $\left(75^{\mathrm{r}}\right)$, sau a unui substantiv: ,să apucă sângur bărbatul şi cernu ţerna" $\left(30^{v}\right)$, „,numai mânie sângură este un rău pre mare" $\left(60^{v}\right)$, ,sângur împăratul ar fi fost vinovat” ( $\left.73^{\vee}\right)$, sau a unui numeral colectiv: ,sânguri amândoi să vorbască" (74). Alteori, adjectivul singur nu este însoțit de niciun cuvânt: ,acum am venit sângur nechemat” (72v), „nu-t fi sângură duşmancă vieţii tale” (38 ).

Această tendință de folosire a adjectivului singur în dauna pronumelui de întărire ,este din ce în ce mai accentuată pe măsură ce ne îndreptăm spre perioada modernă" (ILRL, 1997, p. 329), fenomenul fiind preferat de aspectul vorbit al limbii datorită faptului că sintagma pronume/ substantiv + singur, alături de construcțiile chiar tu, tocmai eu, eu personal, eu unul/ una etc., „sunt mult mai concrete decât formele de întărire și mai ușor de folosit”' (GALR, 2005, p. 222).

Pronumele reflexiv deține, la fel ca în limba contemporană, o paradigmă flexionară defectivă, neavând forme speciale pentru nominativ și genitiv, ci doar pentru persoana a 3 -a dativ: $\hat{\imath} \underline{s}\left(10^{\mathrm{v}}, 19^{\mathrm{v}}\right.$ etc. $),-\underline{s}\left(12^{\mathrm{v}}-2,44^{\mathrm{r}}-2\right.$ etc. $), \underline{s}-\left(29^{\mathrm{v}}, 90^{\mathrm{r}}-2\right.$ etc. $)$ și acuzativ: sine $\left(15^{\mathrm{r}}, 93^{\mathrm{r}}\right)$, sâneț $\left(41^{\mathrm{r}}\right)$, se $\left(23^{\mathrm{r}}, 44^{\mathrm{r}}\right.$ etc. $)$, să $\left(14^{\mathrm{v}}, 67^{\mathrm{v}}\right), s-\left(74^{\mathrm{r}}-3,99^{\mathrm{r}}-2\right.$ etc.).

Distribuția formelor neaccentuate ale pronumelui reflexiv amintește, în multe privințe, de cea a cliticelor pronumelui personal propriu-zis. Astfel, sunt consemnate preferențial exemple cu forma neaccentuată de dativ $-s$, notată în poziție enclitică, frecvența formelor etimologice întrecând cu mult pe cea cu $\hat{\imath}$ protetic (43 de apariții față de numai 8 atestări): „trebuie să fie de râs şi de ocară acel împărat ci nu-ş va împlini cuvâ< $>$ tul ci au zis” $\left(19^{v}\right)$, „,muiere acelui slujitoriu să dusă în sat cu o treabă şi-ş lăsă pe bărbat acasă cu un prunc mic” $\left(43^{r}\right),{ }_{\text {,Cu adevărat au }}$ mâncat câinile pe copil, că-ş linge buzile de sânge" $\left(44^{r}\right)$, ,vicleşugurile babii o făcu de-ş pierdu curăţenie ci o ţine" $\left(51^{\mathrm{r}}\right)$, ,muieri să nu-ş ia până nu va învăţa toate meşteşugurile ale muierilor” $\left(61^{r}\right)$ etc.; cf. ,îndată îş opri mânie şi urgie” (19v), „şarpile, de durere, îş scăpă şi-ş borî veninul” $\left(75^{\vee}\right)$.

În raport cu româna contemporană, $-s ̦$ apare în vecinătatea substantivului, marcând valoarea posesivă: ,să culcă în patu-ş să doarmă” $\left(46^{\Upsilon}\right)$, „Atunce începu a grăi cu fimeia-ş" $\left(49^{v}\right)$. Această valoare de posesiune este intensificată de întrebuințarea frecventă, pleonastică, a adjectivului pronominal posesiv și, mai rar, a pronumelui personal, acestor contexte alăturându-se și ș-: ,,având poftă împăratul ca să-ş înveţă pre fiiul său întru învăţăturile cărţii”" $\left(1^{v}\right)$, ,,fiindcă-ş pusăsă ochiul şi gândul ei pre cucon" $\left(9^{\prime}\right)$, „nu 1-om lăsa să-Ş omoare pe fiiul său” $\left(12^{v}\right)$, , ,l-am lăsat de ş-au omorât pe fiiul său" $\left(12^{v}\right)$, ,să nu-1 lăsăm să-ş omoare pe fiiul său" $\left(12^{v}\right),$, ,Şau făcut râs de înţelepciune lui" (19'), „băieşul gândi să-ş aducă pe muiere $s a^{\prime \prime}$ (34'), „,becisnicul om şi-ş adusă pe muiere $s a^{\prime \prime}\left(34^{v}\right)$, ,au auzit că sânt slobode muierile a-ş face voiele sale" $\left(61^{v}\right)$, ,ş-ar fi omorât pe fiiul său" $\left(73^{v}\right)$. 


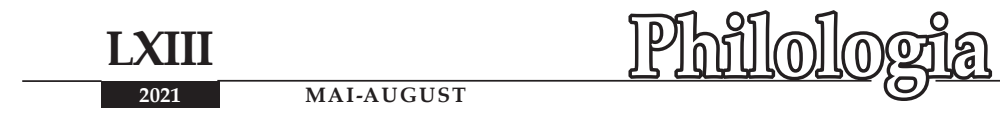

Forma accentuată, nonclitică, de acuzativ sine apare notată rar (doar nouă atestări) și este însoțită de prepoziții: ,zisă întru sine” $\left(15^{\mathrm{r}}, 39^{\mathrm{r}}, 62^{\mathrm{r}}\right)$, ,numa gândi pin sine" $\left(46^{v}\right)$ sau apare în construcții emfatice, sine fiind dublat de cliticul reflexiv: „să face el sângur pre sine înţelept” $\left(75^{1}\right)$, ,să osteneşte ca să $s a ̆$ folosască pe sine" $\left(93^{\vee}\right)$. O dată, este consemnată forma învechită sâneț, întărită de adjectivul singur cu valoare de pronume de întărire: ,sângur de sâneț cunoscându-l că i să cade această pedeapsă" $\left(41^{\mathrm{r}}\right)$.

In calitate de clitice reflexive în acuzativ apar formele se, $s$-, cu 124 de apariții, și săa -să, ce însumează un număr apreciabil de ocurențe (370): ,să cade să $s e$ ferească tot omul” $\left(14^{\prime}\right)$, ,să se joace” $\left(95^{\vee}\right)$, ,temându-să $"\left(25^{\mathrm{r}}\right)$, ,foarte $s$-au bucurat" $\left(82^{v}\right)$ etc.

Pronumele (adjectivul) posesiv cunoaște mai multe forme flexionare. Astfel, la persoana 1 singular masculin mieu, cu 46 de ocurenţe, apare, majoritar, în exemple de felul fiiul mieu" $\left(2^{\mathrm{r}}-3,70^{\mathrm{v}}-2,99^{\mathrm{v}}-3\right.$ etc.) și, mai rar, în cele ca tatămieu $\left(6^{\mathrm{r}}, 70^{\mathrm{r}}-2\right)$, tătâni-mieu $\left(27^{\mathrm{r}}, 70^{\mathrm{r}}\right)$, întrecând în frecvență actualul meu, cu 20 de atestări: fiul meu $\left(15^{\mathrm{r}}, 73^{\mathrm{r}}-3,90^{\mathrm{r}}-4\right.$ etc.), tătâni-meu $\left(32^{\mathrm{r}}\right)$. Femininul este reprezentat de forma monoftongată $m e$, cu 28 de ocurențe: „viiața $m e^{\text {” }}\left(2^{\mathrm{v}}, 82^{\mathrm{r}}-2\right.$ etc.) și de cea modernă mea, cu 7 apariții: „muiere mea” $\left(39^{\mathrm{r}}, 75^{\mathrm{r}}, 97^{\mathrm{r}}-2\right.$ etc. La plural masculin sunt consemnate doar formele miei: „tovarăşii miei” $\left(79^{r}\right)$ și mii: „sfetnicii mii” $\left(28^{\mathrm{v}}\right)$, ,prietinii mii” $\left(70^{\mathrm{r}}, 85^{\mathrm{r}}\right)$, ,ai mii” $\left(82^{\mathrm{r}}\right)$, iar la feminin apare forma mele, identică cu cea din limba contemporană: ,slugile mele” $\left(27^{\mathrm{v}}-3\right.$ etc.).

La persoana a 3-a, singular și plural, sunt consemnate toate formele adjectivului posesiv: „Această istorie au scris-o mai întâi Mosus filosoful pentru Chir, împărat al persilor, şi pentru naştire fiiului său” $\left(1^{1}\right)$, ,chemă gazda pe muierea $s a^{\prime \prime}\left(62^{v}\right)$, „împăratul atunce, după vorba muierii, căută la domnii săi” $\left(94^{r}\right)$, „tot omul să cade să aibă trii porţi la vorbile sale" $\left(60^{v}\right)$, întreaga serie înregistrând un număr destul de mare de atestări (120), marea majoritate revenind formei său (102).

Raport de posesiune redau și formele pronumelui personal lui, ei, lor, care intră în alternanță cu $s a ̆ u, s a$, fără însă a le depăși ca frecvență, ele acumulând 60 de ocurențe: „luând filosoful pe cucon, 1-au dus la casa lui” (3 $3^{r}$, ,învăţă pe taină stăpânul pe pasăre ca să păzască pe jupineasa lui" $\left(17^{1}\right)$, ,neguţitoriul, auzindu aceste cuvinte de la babă, le pusă în gândul lui” $\left(86^{r}\right)$, „muiere cu mare vicleșug au răspunsu cătră bărbatul ei" $\left(25^{v}\right)$, ,ea spusă toată pricina ei acelui cucon" $\left(81^{v}\right)$, ,muierile cele răle cu vicleşugurile lor cele ci vor să facă îndată fac” $\left(57^{r}\right)$ etc. Preferință pentru întrebuințarea adjectivului posesiv caracterizează scrierile elaborate în partea nordică a dacoromânei, pe când textele sudice folosesc cu predilecție formele pronumelui personal (vezi ILRL, 1997, p. 127-128).

Forma sale este întrebuințată, o dată, în legătură cu subiectul aflat la plural, construcția redând pluralitatea posesorilor: ,sânt slobode muierile a-ş face voiele sale" $\left(61^{v}\right)$. Fenomenul prezent în perioada veche a limbii române (ibidem) este în descreștere în a doua jumătate a secolului al XVIII-lea (ibidem, p. 330).

O caracteristică a textului Sandipa este întrebuințarea frecventă a formelor adjectivului posesiv în legătură cu subiectul, situație ce se regăsește în textele vechi românești (vezi Berea, 1961, p. 324-325): ,dedi pre fiiul său în mâna Sandipei” (3v), „mult ceas întrebându-l tatăl său, el nimică nu răspunde” $\left(7^{1}\right)$, ,au iertat împăratul 
pre fiiul său” (19v), ,împăratul priimi cuvântul fiiului său” $\left(77^{\mathrm{r}}\right)$, „chemă gazda pe muierea $s a^{\prime \prime}\left(62^{v}\right)$, ,tot omul să cade să aibă trii porţi la vorbile sale" $\left(60^{v}\right)$, ,împăratul atunce, după vorba muierii, căută la domnii săi” $\left(94^{\prime}\right)$, „nimică nu zisă muierii sale" $\left(46^{v}\right)$ etc.

Mai rar, unele forme ale pronumelui personal cu valoare posesivă apar notate în legătură cu obiectul: „,voinicul să aprinsă tare de dragoste $e i$ și de frumusețile $e i ”\left(36^{\mathrm{r}}\right)$, „nu voiu să-i împlinescu pohta $e i^{\prime}\left(71^{\vee}\right)$, „Dumnezeu au dat la toate dobitoacile hrana lor" $\left(76^{\vee}\right)$.

Său, sa și lui, ei, împreună cu cliticele reflexive, dublează valoarea posesivă, dând naștere unor construcții pleonastice de tipul ,având poftă împăratul ca să-ş înveţă pre fiiul său întru învăţăturile cărții” ( $\left(1^{v}\right)$ (vezi supra).

Un ultim comentariu care se impune este apariţia frecventă a formelor său, $s a$ și $m e u, t a ̆ u$ în vecinătatea unor substantive nearticulate în nominativ-acuzativ ce desemnează grade de rudenie sau relații sociale, rezultând construcții unitare, legate, caracteristice limbii populare și vorbirii familiare, unele dintre acestea nefiind recomandate astăzi de norma limbii române literare contemporane (vezi Avram, 1986, p. 133-134; GALR, 2005, p. 239): ginere-său (15 ), mă-sa (98'), stăpână-său $\left(22^{\mathrm{r}}, 24^{\mathrm{v}}-3\right)$ tată-său $\left(4^{\mathrm{v}}, 20^{\mathrm{v}}, 70^{\mathrm{v}}-3\right.$ etc.), tată-mieu $\left(6^{\mathrm{r}}, 70^{\mathrm{r}}-2\right)$, tată-tău $\left(6^{\mathrm{v}}, 9^{\mathrm{r}}, 9^{\mathrm{v}}-2\right)$. În alte contexte, substantivele din componența sintagmelor nu flexionează sau flexionează neobișnuit: „nimică n-au spus stăpână-său” (17 $7^{\vee}$, „spusă stăpână-său” (84), ,închinându-să tătâni-său” (5 $\left.5^{r}\right)$, ,spusă toată pricina tătâne-său” $\left(15^{\mathrm{r}}\right)$, „un filosof sfetnic al tătâne-său” (31 $)$, "Grăieşte tătâni-mieu” $\left(27^{\prime}\right)$, „după poronca tătâni-meu” (32 ), ,toate aceste le voi spune tătâni-mieu” $\left(70^{1}\right)$, „Acum roagă-te tătâni-tău” $\left(28^{v}\right)$.

Pronumele (adjectivul) demonstrativ are o paradigmă flexionară care, în unele privințe, se deosebește de cea din limba de astăzi. De exemplu, pronumele și adjectivul demonstrativ de apropiere acest, în poziție antepusă și postpusă, apare notat fără afereza lui $a$ - și este minoritar în comparație cu acist (mai rar formele sale gramaticale), fonetismul arhaic înregistrând 27 de atestări față de 7 aparitii ale formei actuale: ,acist împărat” ( $\left.1^{\mathrm{v}}, 11^{\mathrm{v}}\right)$, ,,acist lucru” $\left(3^{\mathrm{r}}, 8^{\mathrm{r}}\right)$, ,acist om” $\left(15^{\mathrm{v}}, 25^{\mathrm{v}}\right.$, $\left.62^{v}\right)$, ,acist ceas" $\left(28^{v}\right)$, ,acist cuţit" $\left(31^{\mathrm{r}}\right)$, , acist oraș” $\left(39^{v}\right)$, , ,acist vicleşug” (40 ),

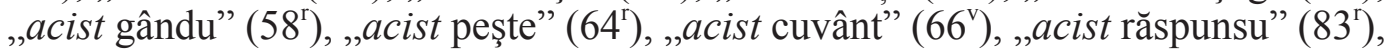
„acista-i drumul” (31 $\left.1^{\mathrm{v}}\right)$, „Ci peşti este acista, bărbate?” $\left(66^{\mathrm{v}}\right)$, , ,acista este peştile ci

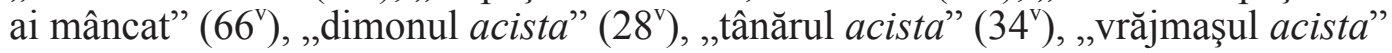
$\left(35^{\mathrm{r}}\right)$, „lemnu de acista” $\left(85^{\mathrm{r}}\right)$, ,înainte de aciste” $\left(8^{\mathrm{v}}\right)$, ,unul ca acista” $\left(20^{\mathrm{r}}\right)$, „să umpli tipsie de aceştie” $\left(88^{\mathrm{v}}\right)$, , ,acistui neguţitor” $\left(51^{\mathrm{r}}\right)$, , ,acistor doi” $\left(82^{\mathrm{v}}\right)$, ,acest dascal" $\left(78^{\prime}\right)$ etc. (despre forma acist, vezi Georgescu, 1982, p. 394).

Forma fără deicticul - $a$ este preferată față de forma cu - $a$ : ,,aceasta dascal” $\left(2^{\prime}\right)$, ,întru aceasta zi” $\left(29^{\vee}\right)$, ,acesta copil” $\left(97^{\vee}\right)$, ,într-acesta chip” $\left(51^{\vee}\right)$, fenomen curent în scrierile din perioada veche a limbii române (vezi Densusianu, 1961, p. 120; Teodorescu, Gheție, 1977, p. 103-104; Roman Moraru, 1982, p. 77; Chivu, 1993, p. 181-182; Vieru, 2014, p. 82).

La genitiv-dativul feminin al lui aceasta, în prepoziția și, uneori, în postpoziția substantivului, forma întrebuințată este cea etimologică: ,gura aciştii babi” (39v),

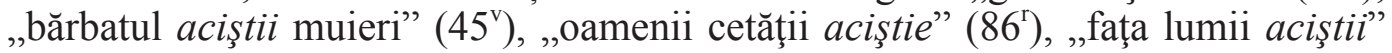




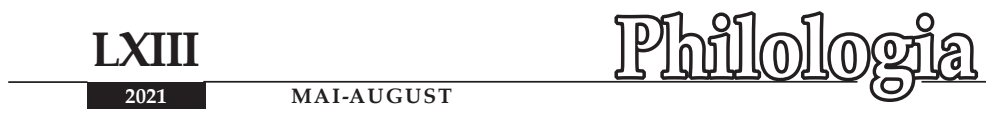

$\left(54^{1}\right)$, „aceştei blăstămate” (55 $)$, ,am dat aceştii căţeli” $\left(66^{\mathrm{r}}\right)$, ,aceştie i să cade” $\left(96^{r}\right)$, la fel ca în textele din secolul al XVI-lea (vezi Densusianu, 1961, p. 120-121) şi în cele contemporane cu manuscrisul Sandipa (vezi ILRL, 1997, p. 330). Forma modernă acestei nu este consemnată (în privința istoriei formelor refăcute, vezi Frâncu, 1972, p. 26 și urm.).

Pluralul feminin al lui aceasta cunoaște, în cele 33 de apariții, doar forma cu ea monoftongat: aceste $\left(5^{\mathrm{v}}, 58^{\mathrm{r}}, 72^{\mathrm{r}}, 100^{\mathrm{r}}\right.$ etc. $)$.

Adjectivul demonstrativ de depărtare acel, acea se remarcă prin formele astăzi arhaizante: ,acela neguţitor” $\left(88^{\mathrm{v}}\right)$, ,ace (= acea) vreme” $\left(6^{\mathrm{l}}\right)$, ,ace muiere” $\left(8^{\mathrm{r}}\right)$, „ace învățătură” $\left(9^{v}\right)$, , ,ace ocară” $\left(12^{1}\right)$ etc., cu 44 de atestări, ,aceea pâine” (22 $\left.2^{\mathrm{v}}-2\right)$, „aceea fimei” ( $\left(24^{v}\right)$, precum și prin formele de genitiv-dativ: ,acilii muieri” (45 $)$, „acilii fimei” $\left(48^{\mathrm{v}}\right)$, ,spusă toate aceste acii babe” $\left(45^{\mathrm{r}}\right)$, ,casa acii fimei” $\left(46^{\mathrm{r}}\right)$.

Pronumele demonstrativ de diferențiere este folosit în forma regională celalant $\left(82^{\mathrm{v}}, 83^{\mathrm{r}}\right)$ și, la plural, în cea învechită ciialalţi $\left(95^{\mathrm{v}}\right)$, ciielalţi $\left(95^{\mathrm{v}}\right)$.

Pronumele (adjectivul) interogativ-relativ. Care înregistrează, pentru nominativ-acuzativ, forma articulată carile $\left(13^{\mathrm{r}}, 20^{\mathrm{r}}-4,52^{\mathrm{r}}, 90^{\mathrm{r}}\right.$ etc. $)$, fără însă a marca opoziția masculin : feminin (opoziție curentă în textele vechi). Carile desemnează substantive de genuri și numere diferite și este concurat de forma nearticulată care $\left(8^{\mathrm{r}}, 38^{\mathrm{v}}-2,73^{\mathrm{r}}, 100^{\mathrm{v}}-3\right.$ etc. $)$. O predilecție anume în folosirea uneia din cele două forme nu se observă, aparițiile numerice fiind aproximativ egale: 34 pentru forma nearticulată și 32 pentru forma articulată.

Genitiv-dativul relativului este consemnat în câteva situații și se evidențiază printr-un acord și prin forme flexionare mai puțin obișnuite în raport cu limba actuală: „o pasire [...] căruia îi zic elinenii psidac” $\left(17^{\mathrm{r}}\right)$, ,Aceasta-i baba cării i-am dat dulama” $\left(48^{v}\right)$, „,dedi dulama voinicului căruie o vândusă” $\left(49^{v}\right)$.

În acuzativ care, carile apar notate în vecinătatea unor prepoziții: dintri carile $\left(97^{\mathrm{r}}\right)$, intru care $\left(38^{\mathrm{v}}\right)$, pe carile $\left(20^{\mathrm{r}}\right)$, pre carile $\left(41^{\mathrm{r}}\right)$. Mult mai numeroase sunt însă situaţiile în care relativul, de regulă, nedublat de formele neaccentuate ale pronumelui personal, nu este însoțit de prepoziţia $p(r) e$ : ,găsi dulama cari o vândusă” $\left(46^{r}\right)$, „dulama cari am cumpărat-o de la dumneta” $\left(48^{\mathrm{r}}\right)$, ,,este vro învăţătură cari nu-l vei fi învăţat pe fiiul mieu” $\left(77^{\vee}\right)$, „,erşind eu acel pământ ca să-1 lucrez, carile mi $l$-o dat" $\left(16^{\mathrm{r}}\right)$, ,,ave un câine carile de mulţi ani $\hat{\imath} l$ ţine" $\left(43^{\mathrm{r}}\right)$, ,te vei căi pentru ficiorul tău carile mult doriei” $\left(44^{v}\right)$, ,poate ţ-a cere un lucru carile nici noi toţ, cetăţenii, nu vom pute avea” $\left(88^{v}\right)$, „oi scoate și eu ochiul meu carile zici că $l$-am furat” $\left(90^{1}\right)$.

Alteori, relativul care este folosit în accepțiile „,despre care”: „toate tainile lui mie mi le spune, care, cându- $m$ spune ceva, nimine să nu ştie această taină" $\left(8^{v}\right)$; ,din care”: ,agiunsără la o fântână care, cine bea dintr-însa, dintr-ace fầntână” $\left(31^{v}\right)$, „o nevastă foarte frumoasă şi ghizdavă, care din buzile ei cură dulceaţă" $\left(38^{v}\right)$; , ,după care”: „nu luo chieptinile la care vinisă” $\left(79^{v}\right)$.

$\mathrm{Cu}$ valoare adjectivală, care apare în construcţii numite în literatura de specialitate „legătura relativă” (vezi Iliescu, 1956, p. 28; Nilsson, 1969, p. 12-14; Edelstein, 1971, p. 337-343; Edelstein, 1978, p. 93-96), în care, de la obișnuita reluare a antecedentului sau a echivalentului său sinonimic: "Şi-i dedi o carte să o cetească, in care carte scriia" $\left(14^{\mathrm{r}}\right),$, -am apucat cu alte vorbe răle ale viclenii $<\mathrm{i}>$, cu care vicleşug am scos cuvânt din gura lui” $\left(93^{\vee}\right)$ s-a ajuns la îmbinări pleonastice, 
al căror relativ, desemantizat, se prezintă ca element joncţional coordonator (vezi Edelstein, 1971, p. 342): ,̂̂l deprind oamenii şi nu să tem de împăratul, care întâi acum, de nu vei poronci” $\left(20^{r}\right)$, ,ai poroncit să omori pe fiiul tău, cari eu, ca o slugă dre<a $>$ ptă, ît aduc aminte" $\left(21^{\mathrm{r}}\right)$, ,şi-t $t$ pune gând rău ca să omori pe fiiul tău făr de vină, care apoi, pe urmă, te vei căi” $\left(21^{v}\right)$, ,n-ai făcut ca să afli adevărul, care mă rog să mă asculți” $\left(35^{\vee}\right)$.

Cine $\left(31^{\mathrm{v}}, 40^{\mathrm{r}}, 95^{\mathrm{v}}\right.$ etc.) și forma de genitiv al (e) cui $\left(32^{\mathrm{r}}, 99^{\mathrm{r}}\right)$ nu prezintă deosebiri în raport cu formele din limba contemporană. În fraza „să-ş ie plata cine cum ş-a agonesi” $\left(53^{v}\right)$ relativul are sensul pronumelui nehotărât cineși ,fiecare”.

Invariabilul ce este întrebuințat fără diferențe atât pentru ființe, cât şi pentru lucruri, atât la singular, cât şi la plural, fapt ce se răsfrânge asupra frecvenței mai mare a lui ce în dauna omonimului său, care, situație asemănătoare consemnată de cercetătorii textelor vechi românești (vezi Iliescu, 1956, p. 26): „Era un om şi cu fimeia sa $c i$ să luoasă cu lege” $\left(35^{\vee}\right)$, ,un prunc mic, ce era numai unul în faşă” $\left(43^{\urcorner}\right)$, „izbăvești-mă de frică şi de primejdie ce me-u venit” $\left(81^{\vee}\right)$, „smochinile cele mai coapte şi mai dulci ci cad" (41") etc.

La fel ca relativul care, ce este întrebuințat cu sensul „cu care”: „Ci acest om, ci m-am apucat cu dânsul” ( $\left(89^{v}\right)$; ,,în care”: ,până la vreme $c i$ au zis că l-a învăţa”" $\left(4^{r}\right)$, ,într-acele 7 zile $c i$ n-au grăit" $\left(73^{r}\right)$, ,în trii ani $c i$ ai fost întâi la dascalul cel dintâi” ( $\left(91^{\vee}\right)$, ,în ceasul $c i$ s-au născut $\left(97^{\vee}\right)$; ,de care”: „să- $m$ ceară el de acest feliu $c i$ ai zis dumnata" $\left(88^{\vee}\right)$. Mult mai numeroase sunt însă exemplele în care invariabilul ce este folosit în acceptia ,pe care”, de obicei nereluată de formele neaccentuate ale pronumelui personal: ,,acest lucru $c i$ am făgăduit” $\left(3^{r}\right)$, ,,după zapis ce au dat împăratului” $\left(5^{\vee}\right)$, ,toată învăţătura filosofie $<i>c i$ ai învăţat” $\left(6^{v}\right)$, ,aceste cuvinte $c i$ ai zis tu" $\left(10^{1}\right)$, „Pilda filosofului întâi ce au spus cătră împăratul” $\left(13^{v}\right)$, „Cum frământai ace pâine $c i$ vindei slugii mele?” $\left(22^{v}\right)$, „să fie dreaptă judecata $c e$ vei face” $\left(42^{v}\right)$, ,după tocmala $c i$ am făcut cu tine” $\left(86^{v}\right)$, ,,această cățe $c i$ o privesc ochii tăi” " $\left(37^{\mathrm{r}}\right)$, ,povoara ci o am este de vânzare" $\left(84^{v}\right)$, ,luo toate scrisorile ci le scrisăse" $\left(68^{v}\right)$ etc.

Cât este identic cu omologul său din limba actuală: „Câte au grăit toate sânt adevărate” $\left(15^{\vee}\right)$, „nu m-am apucat să beu toate gârlele câte cură în mare” $\left(89^{v}\right)$, „câte învăţături vre să mă înveţe, toate le zugrăvi pe păreţi” $\left(100^{r}\right)$ etc.

Relativul compus este reprezentat prin aceleași forme ca în limba contemporană: ,,cel ci luo banii apucă pi altă uliţă” $\left(80^{1}\right)$, „,cei ce au mâncat laptile” $\left(76^{\vee}\right)$, „,nu-i pricina celui ce au făcut masă” $\left(76^{\prime}\right)$; cf. însă, o dată, forma amplificată cu deicticul - $a$ : ,,văzind pe cela ce ţine coada vulpii în mână” $\left(95^{\prime}\right)$.

Pronumele (adjectivul) nehotărât. Pronumele nehotărât altul, singur sau împreună cu pronumele negativ, înregistrează pentru feminin singular forma altă, cu sensul ,altceva”: ,de altă nu este rugăminte me” $\left(60^{r}\right)$, ,altă nu gândie” (61 v), situație consemnată în textele din secolul al XVI-lea (vezi Densusianu, 1961, p. 123). În corelație cu pronumele negativ nimeni pronumele nehotărât are înțelesul de „altcineva”: ,nimine altul nu ştie de aceasta” $\left(17^{\mathrm{r}}\right)$. Alte apare articulat și în prepoziția adjectivului multe în sintagma ,altile multe” $\left(9^{r}\right)$.

Atât, cu valoare adjectivală, are formele gramaticale diferite de cele actuale datorită naturii fonetice: atâța $\left(68^{\mathrm{r}}\right)$, atâte $\left(60^{\vee}\right)$. 
Pronumele nehotărât derivat cineși are semnificația de „fiecare”: „și-ş pecetluiră cineş punga cu pecetea sa" $\left(78^{\vee}\right)$, sens consemnat frecvent în toate textele vechi românești (vezi Densusianu, 1961, p. 124).

Fiecare, prin cele două atestări, se prezintă sub formă învechită și regională: fieş̧tecarile $\left(87^{\mathrm{r}}\right)$, ,a fieştecăruia" $\left(100^{\mathrm{r}}\right)$.

Pronumele nehotărâte oarece $\left(46^{\mathrm{r}}, 61^{\mathrm{v}}\right)$ și oarecine $\left(46^{\mathrm{r}}, 100^{\mathrm{v}}\right)$ sunt formate cu relativele ce și cine și au sensul de „ceva” și, respectiv, „cineva”.

Câteva pronume nehotărâte apar cu elementele separate: „ori în care parte căuta” $\left(3^{\vee}\right)$, ,ori la care chip căutam” $\left(100^{v}\right)$, „, tipsie plină ori de ce vei pohti” $\left(85^{\mathrm{v}}\right)$. Mai numeroasă este însă forma sudată: orice $\left(43^{\mathrm{r}}, 88^{\mathrm{r}}\right)$, orici $\left(4^{\mathrm{r}}, 60^{\mathrm{r}}\right.$ etc. $)$.

Adjectivul demonstrativ tot, cu sensul de „fiecare”, este precedat de prepoziția $a$ și redă valoarea de genitiv: ,ajutoriu şi păzitoriu $a$ tot omul” $\left(71^{1}\right)$.

Vreunul, ca pronume și adjectiv nehotărât, apare rar și coincide, ca formă, cu omologul său actual: vreun $(u l)\left(79^{\mathrm{r}}, 95^{\mathrm{r}}\right)$, iar femininul vreo este consemnat numai ca adjectiv, o dată în forma contemporană vreo $\left(7^{\vee}\right)$, a doua oară sub forma vro $\left(77^{\vee}\right)$, astăzi învechită și populară.

Pronumele negativ nimeni are formele nime $\left(19^{\mathrm{v}}, 33^{\mathrm{v}}, 98^{\mathrm{r}}\right)$, nimi $\left(11^{\mathrm{v}}\right)$, nimene $\left(40^{\mathrm{v}}\right)$, nimine $\left(8^{\mathrm{v}}, 17^{\mathrm{r}}, 20^{\mathrm{r}}-2,61^{\mathrm{r}}, 77^{\mathrm{v}}, 78^{\mathrm{r}}-2\right)$, nime și nimi fiind caracteristice pentru Moldova (vezi Gheție, 1975, p. 163-164).

Nimic, în cele 40 de atestări, este notat doar în varianta fonetică cu -ă: nimică $\left(2^{\mathrm{r}}-2,25^{\mathrm{r}}, 65^{\mathrm{r}}-3,91^{\mathrm{v}}\right.$ etc. $)$, iar compusul niciun nu se diferențiază prin nimic de forma de astăzi: niciun ( $1^{\mathrm{v}}$ etc.), nicio $\left(2^{\mathrm{r}}\right.$ etc.).

În concluzie, morfologia pronumelui se remarcă printr-o vădită tendinţă de simplificare şi reducere a formelor arhaizante, care sunt împinse spre periferia sistemului, inovaţiile acceptate ulterior de norma limbii literare actuale impunându-se tot mai evident.

\section{Referințe bibliografice:}

AVRAM, Mioara. Gramatica pentru toți. București, 1986.

BEREA, Elena. Din istoria posesivului său-lui în limba română. În: Studii și cercetări lingvistice, 1961, nr. 3, p. 319-333.

BUZĂ, Emanuela, ZGRAON, Florentina. Prefețe și epiloguri din secolul al XVI-lea. Text stabilit, studiu filologic, studiu lingvistic și indice de Emanuela Buză și Florentina Zgraon. În: Texte românești din secolul al XVI-lea. Coordonator, Ion Gheție. București, 1982, p. 467-636.

CHIVU, Gheorghe. Codex Sturdzanus. Studiu filologic, studiu lingvistic, ediție de text și indice de cuvinte de Gheorghe Chivu. București, 1993.

DENSUSIANU, Ovid. Istoria limbii române. Secolul al XVI-lea. Vol. II. Ediție îngrijită de prof. univ. J. Byck. București, 1961.

EDELSTEIN, Frieda. Despre „legătura relativă” în limba română. În: Cercetări de lingvistică, 1971, nr. 2, p. 337-343.

EDELSTEIN, Frieda. Despre sintaxa relativului care. În: Cercetări de lingvistică, 1978, nr. 1, p. 93-96. 
FRÂNCU, C. Din istoria demonstrativelor româneşti: formele (a)cele(i), aceleiaşi, (a)celeilalte, (a)cestei(a). În: Studii de limbă literară şi filologie. Bucureşti, 1972, p. 25-52. GALR = Gramatica limbii române. I. Cuvântul. București, 2005.

GEORGESCU, Magdalena. Glosele Bogdan. Text stabilit, studiu filologic, studiu lingvistic și indice de Magdalena Georgescu. În: Texte românești din secolul al XVI-lea. Coordonator, Ion Gheție. București, 1982, p. 367-464.

GHET,IE, Ion. Baza dialectală a românei literare. București, 1975.

ILIESCU, Maria. Concurenţa dintre pronumele relative care şi ce. În: Studii de gramatică. I. 1956, p. 25-35.

ILRL = Istoria limbii române literare. Epoca veche (1532-1780) de Gheorghe Chivu, Mariana Costinescu, Constantin Frâncu, Ion Gheţie, Alexandra Roman Moraru şi Mirela Teodorescu. Coordonator, Ion Gheţie. București, 1997.

MAREȘ, Alexandru. Liturghierul lui Coresi. Text stabilit, studiu introductiv și indice de Al. Mareș. București, 1969.

NILSSON, Elsa. Les termes relatifs et les propositions relatives en roumain moderne. Etude de sintaxe descriptive. Lund, 1969.

ROMAN MORARU, Alexandra. Catehismul lui Coresi. Text stabilit, studiu filologic, studiu lingvistic și indice de Alexandra Roman Moraru. În: Texte românești din secolul al XVI-lea. Coordonator, Ion Gheție. București, 1982, p. 21-127.

TEODORESCU, Mirela, GHET,IE, Ion. Manuscrisul de la Ieud. Text stabilit, studiu filologic, studiu de limbă şi indice de Mirela Teodorescu, Ion Gheție. Bucureşti, 1977.

VEREBCEANU, Galaction. Un manuscris al Sindipei de la sfârșitul secolului al XVIII-lea. Text. In: Philologia. 2017, nr. 1-2, p. 35-55; nr. 3-4, p. 67-89; nr. 5-6, p. 113-130.

VEREBCEANU, Galaction. Considerații filologice asupra manuscrisului „Sandipa”. În: Philologia. 2019, nr. 3-4, p. 49-63.

VEREBCEANU, Galaction. Studiu lingvistic asupra manuscrisului „Sandipa”. Grafia (1). În: Philologia. 2020a, nr. 3-4, p. 93-102.

VEREBCEANU, Galaction. Studiu lingvistic asupra manuscrisului „Sandipa”. Fonetica (2). În: Philologia. 2020b, nr. 5-6, p. 22-36.

VEREBCEANU, Galaction. Studiu lingvistic asupra manuscrisului „Sandipa”. Morfologia (3.1.). Substantivul. Articolul. Adjectivul. Numeralul. În: Philologia. 2021, nr. $1-2$, p. $75-84$.

VIERU, Roxana. Studiu lingvistic asupra „Paliei de la Orăştie”. Iași: Editura Universității „Al. I. Cuza”, 2014.

Notă: Articolul a fost realizat în cadrul proiectului de cercetare 20.80009.1606.01 Valorificarea științifică a patrimoniului lingvistic național în contextul integrării europene, Institutul de Filologie Română „B. P.-Hasdeu” al MECC. 


\title{
INDICI LEXICALI VARIAŢIONALI ÎN „AMINTIRI DIN COPILĂRIE” DE ION CREANGĂ LILIANA BOTNARI
}

\author{
Doctor în filologie \\ E-mail: botnari.liliana86@gmail.com \\ ORCID: https://orcid.org/0000-0002-9909-2982 \\ Institutul de Filologie Română „Bogdan Petriceicu-Hasdeu” (Chișinău)
}

\section{Lexical Indices of Variation in „Amintiri din copilărie” by Ion Creangă}

\begin{abstract}
Ion Creangă's literary work is an inexhaustible source of expressiveness, which lends itself to versatile interpretations, from various perspectives, never finished. In this study, we analyze the lexical variation indices of „Amintiri din copilărie” through the prism of the variational dimensions: diachrony, diatopia, diastratia and diaphasia. Their inventory demonstrates that Ion Creangă's work abounds in contextual expressive-aesthetic meanings and is a perfect model for rendering the simultaneous harmonious functioning of these indices, which actually builds the oral and popular character of his writing. Obsolete lexical units, archaic forms, as well as words of Slavic origin are indices of diachronic and diatopic variation. The terms of popular occupations or the lexemes related to the village life and its activities become diastratic indices, their intentional insertion involving various moods, emotions or attitudes.
\end{abstract}

Keywords: indices of variation; diachronic, diatopic, diastratic, diaphasic indices; orality; archaic units; terms of popular occupations.

\section{Rezumat}

Opera crengiană este o inepuizabilă sursă de expresivitate, care se pretează la polivalente interpretări, din diverse perspective, niciodată finite. Studiul de față analizează indicii de variație lexicali ai „Amintirilor din copilărie” prin prisma dimensiunilor variaționale: diacronie, diatopie, diastratie și diafazie. Inventarierea acestora ne permite să observăm că lucrarea lui Ion Creangă abundă în semnificații expresiv-estetice contextuale și este un model perfect de redare a funcționării simultane armonioase a acestor indici, ce edifică, de fapt, caracterul oral și popular al scriiturii crengiene. Unităţile lexicale învechite, arhaice, precum şi cuvintele de origine slavă sunt indici ai variaţiei diacronice și diatopice, iar termeni ai meseriilor populare sau lexeme referitoare la viaţa satului şi la activităţile acestuia devin indici diastratici, inserarea intenţionată a acestora implicând variate stări de spirit, emoţii sau atitudini.

Cuvinte-cheie: indici de variație; indici diacronici, diatopici, diastratici, diafazici; oralitate; unități arhaice; termeni ai meseriilor populare. 
Delimitarea unei limbi în varietăți diacronice, diatopice, diastratice sau diafazice nu poate fi decât de ordin metodic, or, funcționarea unei limbi include toate aspectele acesteia, perspectiva completă: realizarea în timp, spațiu, în funcție de modalitățile de expresie, uz și mediu social etc. Astfel, în discursul unei persoane sau în limbajul operelor literare nu pot fi reliefate varietăți diatopice, diastratice, diafazice etc. pure, ci pot fi identificați indicii de variație, mărci variaționale în functiie de diversele dimensiuni variaționale, care se sudează, se modelează adaptându-se la statutul social al vorbitorului, la dialectul/ graiul pe care îl vorbește acesta, la context, la interesele profesionale proprii sau la cele ale interlocutorului etc.

Relevante, în acest sens, ni s-au părut constatările lingvistului F.-T. Olariu care menționează că ,,a așeza stilurile la baza diversității diastratice corespunde unei echivalări, practic, a unităților sinfazice cu cele sinstratice, fapt ce atestă strânsa corelație între variația stilistică și cea sociolingvistică în cadrul proteicului spațiu al comunicării publice" (Olariu, 2017, p. 117). Prin urmare, toate tipurile de varietăți se întrepătrund și interferează, fiind simultan prezente într-o situație de comunicare, mai ales la nivelul lexical al limbii, în care se atestă un împrumut continuu, conștient sau mai puțin conștient, între varietăți.

Limba lui Ion Creangă, colorată, dulce sau pipărată, surprinzătoare sau hazlie, cuminte sau ghiduşă, este un exemplu perfect de împletire a expresivitătiii, a oralităţii, a indicilor de variație ai lexicului din perspectiva dimensiunilor variationale, toate acestea fiind ingenios edificate în diverse contexte intrinsec estetice, decodificând, astfel, talentul și intuiția artistică a scriitorului. În același sens, lingvista Viorica Molea afirmă: „limbajul oral crengian, re-gândit, re-modelat, re-estetizat în maniera unui artist precum este vestitul scriitor humuleștean, devine o sursă de re-interpretare a creației acestuia, din multiple perspective: stilisticoestetică, pragmatică, psiholingvistică, etnolingvistică, sociolingvistică etc., întrucât Ion Creangă este un scriitor mult mai complex decât cred cei ce-l analizează insistând numai asupra umorului său sau asupra jovialității sale" (Molea, 2018, p. 163).

Particularităţile esenţei textului artistic crengian au fost cercetate şi supuse unei analize sub diverse aspecte de către numeroşi exegeţi, precum Şt. Munteanu, I. Iordan, I. Coteanu, G. Călinescu, E. Simion, Z. Dumitrescu-Buşulenga ş. a., prin urmare, nu ne rămâne decât să contabilizăm şi să reliefăm observaţiile şi interpretările acestora, identificând indicii de variaţie ai lexicului operei „Amintiri din copilărie”.

Ion Creangă scrie în varianta limbii vorbite, apelând la un arsenal lexical extrem de divers, autorul fiind un copil al satului, un vorbitor al limbii vii a poporului. Așadar, Amintirile crengiene sunt amintirile unui personaj descendent din lumea satului tradițional al secolului al XIX-lea, cu coloritul său local, rural, selecția mijloacelor de exprimare având nu doar un temei semantic, dar și simbolic, de descriere a epocii. Naratorul humuleştean relevă viaţa satului, activităţile cotidiene ale acestuia, grijile şi interesele. Istorioarele şi năzbâtiile sale, deloc puţine la număr, sunt polarizate în jurul unor teme ca: activităţile ţărăneşti, rutina zilnică, contradicţiile dintre generații, diferenţele de statut, căci „Creangă a însușit arta naraţiunii artistice de la povestitorul popular pe care 1-a ascultat nopți întregi în vremea copilăriei și adolescenței și a reprodus procedeele generale ale limbii 


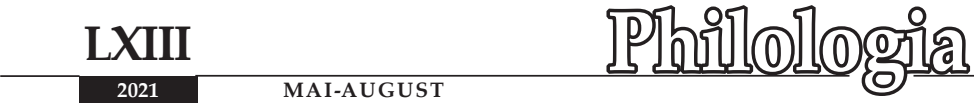

vorbite, ceea ce dă un pronunțat caracter de oralitate povestirii sale" (Bahnaru, 2013a, p. 10).

Pe lângă mărcile stilistice, precum ambiguitatea, calamburul, aluzia sau echivocul, care i-au determinat ,felul de a scrie”, autorul inserează lexeme regionale, indici variationali diatopici sau diacronici, unele dintre acestea fiind identificate de către lingvista V. Molea: „Şi când mă uit înapoi, doi hojmălăi se și luaseră după mine..., context în care, susţine autoarea, elementul regional hojmălăi sugerează un sentiment de frică și antipatie; Era în sat şi dascălul Iordache, fârnâitul de la strana mare, dar ce ţi-i bun? fârnâitul decodifică note peiorative de dispreț și supărare față de situația creată; Iar țăranul, făcându-și cruce, a rămas cu gura căscată, fără să bleştească un cuvânt - a blești, în contextul respectiv, trimite spre o stare de perplexitate și de confuzie" (Molea, 2018,p. 164-165). Accesând o diversă panoplie de mijloace de exprimare sugestive, oralitatea devine o caracteristică inerentă a scriiturii crengiene, indicii de variaţie diatopici şi diastratici ilustrând identitatea stilistică a autorului. În acest sens, enumerăm şi alte elemente lexicale regionale sau populare, cum ar fi: cotigesc în stânga și întru în ograda unui megieș al nostru, în care verbul a cotigi este un regionalism, având sensul de ,a coti”, ,a schimba direcţia”, iar substantivul megieş este un element popular, acestea fiind inserate pentru a conferi naraţiunii nuanţe pronunţate de comic şi oralitate. În contextele următoare: Și tot cihăia mama pe tata să mă deie undeva la școală, când mama lui Nică încearcă să-şi convingă soţul de importanţa învăţării pentru viitorul feciorului lor, verbul a cihăi este un element popular, care reliefează caracterul insistent şi îndârjit al mamei, decisă să obţină ce-şi puse în gând; pe vremea lui mitropolitu Iacob, care era oleacă de cimotie cu noi-lexemul cimotie este un regionalism, cu sensul de „rudă, neam”; Pe acest deal, Smărandă, am fugit în vremea zaverei (...) de frica unei cete de turci, care se bătuse chiar atunci cu volintirii la Secu, în care tatăl evocă amintirile sale, lexemul zaveră este o unitate învechită şi regională, care se referă la Revoluţia din 1821 împotriva stăpânirii turceşti şi conţine în subtext şi o încărcătură expresivă, accentuând emoţiile tatălui, copleşit de frica simţită atunci, iar volintir este o variantă învechită a substantivului voluntar, referindu-se la ostaşii voluntari, care încercau să ţină piept turcilor; Și scroambele ieste a voastre îs pocite - lexemul scroambă este un element regional, având sensul de „cizmă grosolană sau uzată", iar pocite nu face altceva decât să reliefeze şi mai mult imaginea ilară şi încărcată de umor, care sugerează, totodată, şi sentimentul de jenă sau repulsie faţă de acest obiect vestimentar; îi plăteam câte un sorocovăt pe lună, postoronca de dascălul Simeon Fosa din Țuțieni (...) se sfârcâiește toată ziua la tabac, cere câte trei husăși pe lună; Când tragi sorocoveții la musteaţă, de ce nu te olicăiești atâta? - unităţile lexicale sorocovăt şi învechite, care conturează viaţa satului şi realităţile valabile atunci, iar verbele a sfârcâi şi a olicăi sugerează note peiorative de supărare şi indignare.

Din perspectiva celor enunţate mai sus, considerăm că unităţile lexicale învechite, formele arhaice, precum şi cuvintele de origine slavă sunt indici ai variaţiei diacronice sau ai celei diatopice, fiind specifici, mai ales, dialectului moldovenesc: Şi zvârr! cu pravila cea mare după călugări; să se procitească băieții și fetele - verbul a se prociti, a cărui semnificaţie o prezintă chiar naratorul în 
continuare: adică să asculte dascălul pe fiecare de tot de-a învățat peste săptămână; să facem pocinog sfântului Nicolai cel din cui; se ținea praznicul câte-o săptămână incheiată; ahotnică pentru mine; o casă ici, sub tihăraia asta, alta dincolo de Bistrița ş. a.

Bineînţeles, lista elementelor regionale şi populare poate continua, or, toate aceste unităţi sau structuri lexicale, inserate intenţionat în anumite contexte, implică variate stări de spirit, emoţii sau atitudini, care, alături de frazeologismele, proverbele şi dialogurile intercalate în naraţiune, oferă dinamism şi autenticitate textului lui Ion Creangă. Aşadar, înțelepciunea țărănească se relevă prin zicalele şi proverbele utilizate, care au o funcţie de totalizare a celor spuse, de reliefare a moralei sau a învăţăturii deduse dintr-o experienţă trăită: De plăcinte râde gura, de vărzare, și mai tare; tot îs mai aproape dinții decât părinții; Lucrul rău nu piere cu una cu două; s-o luăm de-a chioara; Ce ți-i scris în frunte ți-i pus; Dar nu-i cum gândește omul, ci-i cum vrea Domnul; de unde nu-i, de-acolo nu se varsă; Omul învățat înțelept va fi și pe cel neînvățat slugă-l va avea - înțelepciune de-a mamei etc.

Este evident scopul inserării acestor secvenţe, ca indici ai oralităţii, precum şi cel al indicilor diastratici, ce se referă, mai ales, la o serie de meserii populare, specifice humuleștenilor. Analizând vocabularul ştiinţific şi tehnic, lingvistul V. Bahnaru susține că „este necesar să facem o distincție netă între vocabularul științific și tehnic, care este de origine savantă sau străină, și cel al meseriilor, de cele mai multe ori popular, care face parte din fondul vechi al limbii” (Bahnaru, 2013b, p. 192). Astfel, în opera crengiană, referindu-ne la nivelul lexico-semantic, nu identificăm o variaţie diastratică în sens tradiţional, ci, mai degrabă, nişte mărci variaţionale diastratice, reprezentate prin enumerarea mai multor meserii populare sau a termenilor populari și învechiţ̧i, arhaisme şi istorisme. Pentru a exemplifica, prezentăm câteva fragmente de text în care sunt menţionate unele meserii şi ocupaţii ale timpului: Iar vornicul Nic-a Petricăi, cu paznicul, vătămanul şi câțiva nespălaţi de mazili se purtau printre oameni de colo pănă colo, şi, când deodată, numai iaca vedem în prund câțiva oameni claie peste grămadă, şi unul din ei mugind puternic.; (...) şi-mi ardea sufletul în mine de sete, şi ciobanii şi baciul habar n-aveau de asta, numai se întorceau pe ceea parte în țipetele mele şi horăiau mereu.; Abia despre ziuă s-a îndurat Vasile Bordeianu, strungarul nostru, de s-a dus în Humuleşti, cale de două ceasuri cu piciorul, şi a înştiinţat pe tata, de a venit cu căruţa şi m-a luat acasă.; (...) doftorii satului (...) prăjeau nişte hoștine cu său.; Petre Todosiicăi, crâşmarul nostru, aşă-i că ţi-a mâncat nouă sute de lei?; În altă zi ne trezim că iar vine părintele la şcoală, cu moş Fotea, cojocarul satului.; Intru una din zile, şi chiar în ziua de Sfântul Foca, scoate vornicul din sat pe oameni la o clacă de dres drumul. În fragmentele selectate, identificăm meseriile: paznic, vătăman, cioban, baci, strungar, doftor, crâş̧mar, părinte, cojocar, vornic, unele dintre aceste îndeletniciri, precum vătăman - slujbaș însărcinat cu încasarea dărilor la sate, mazil - persoană însărcinată cu strângerea birurilor, cojocar - persoană care face sau vinde cojoace sau căciuli din blană, sau vornic - primarul satului, 


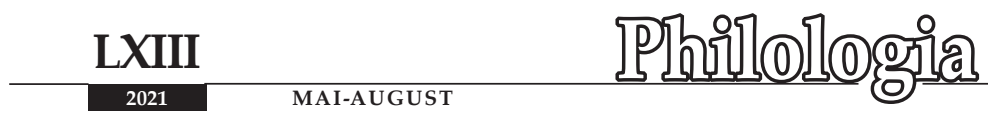

nu mai sunt actuale, ieșind din uzul limbii odată cu schimbarea regimului politic și cu depășirea contextelor politico-istorice sau fiind substituite cu alţi termeni adaptaţi epocii, celelalte referindu-se, mai ales, la activităţile rurale ale humuleștenilor.

Destul de frecvent atestăm un număr considerabil de lexeme referitoare la viaţa satului și la activităţile acestuia, care sporesc caracterul popular al naraţiunii: săpau cu cazmalele; cărau cu tărăboanțele, (...) cu căruțele, (...) cu covățile; Iară gazda (...) se proslăvea pe cuptor, între șanuri, calupuri, astrăgaci, bedreag, dichici și alte custuri tăioase, mușchea, piedecă, hască și clin, ace, sule, clește, pilă, ciocan, ghinț, piele, ață, hârbul cu călacan, clei și tot ce trebuie unui ciubotar; giguri de sumani și lăi, şi de noaten, care se vând și pănură, și cusute.

Efectuând o clasificare tematică a substantivelor enumerate în fragmentul excerptat, se reliefează grupul lexical al instrumentelor utilizate de către un simplu gospodar în activităţile cotidiene, inventarul de unelte utile unui ciubotar sau termeni din domeniul negustoriei.

În acelaşi sens, Zoe Dumitrescu-Buşulenga aminteşte cunoștințele lui Nică referitoare la meșteșugit, agricultură sau culinărie, ultimele fiind redate cu precizie şi poftă în secvențele: ,un cuptior de plăcinte, câțiva pui părpăliți în frigare și prăjiți în unt, o străchinoaie cu brânză cu smântână și mămăliguță" (Dumitrescu-Buşulenga, 2017, p. 195), precum și preparatele din porcul tăiat la Crăciun: costițe de porc afumate, chiște și buft umplut, trandafiri usturoiați și slănină din cea subțire, făcute de casă, tăiate la un loc, fripte bine și cu mămăliguță caldă... sau: Gătitu-le-ați ceva bob fiert, găluște, turte cu julfă și vărzare?; să fi avut pântece unde să pui coliva și bucatele. Tot acest meniu copios, atât de apetisant redat de către Ion Creangă, exprimă aşteptările naratorului, cel care încearcă să-l intercaleze pe cititor în lumea din care provine, în amintirile sale, care evocă atâtea stări de spirit.

In exemplele ce urmează: a învârti suveica; vuia satul de vatale; niște sumani să-i scoată din stative; alții să-i nividească, și să inceapă a-i țese din nou, (...) țevi de făcut la sucală, descoperim un Nică mai potolit, căruia îi plăcea să petreacă timpul pe lângă mama şi celelalte femei când organizau şezători, cunoscând excelent îndeletnicirile femeieşti.

De-a lungul naraţiunii identificăm şi seria semantică a familiei: copilărie, copil, mama, tata etc., intercalarea acestora fiind inevitabilă, decodând sentimentele de duioşie şi gratitudine ale scriitorului faţă de cei care au plămădit ,,boțul de lut” din Humuleşti.

Bineînţeles, un ucenic care a tot citit din ceaslov şi, la insistenţa mamei, învăţa să se facă popă, nu era cu putinţă să nu exceleze în cunoașterea termenilor bisericeşti, etalând un arsenal lexical bogat al sărbătorilor, or, sărbătorile în sate sunt sfinte, fiind prilejuri de a aduna toată comunitatea la un loc, de a petrece frumos, mai ales atunci când ești un copil: Odată, vara, pe-aproape de Moși; în ziua de Sfântul Foca; La Crăciun, când tăia tata porcul; Petrecem noi sărbătorile frumos la părinţi, în Humuleşti, şi după Bobotează ne întoarcem iar în Folticeni; Nu ştiu cum se întâmplă, că aproape de Bunavestire, unde nu dă o căldură ca aceea, şi se topeşte omătul, şi curg pâraiele; într-o duminicăa, prin cârneleaga, a venit tatăl mamei ş. a. Ion Creangă cunoaşte, în special, sărbătorile religioase, denumirile 
populare ale acestora, inserând, de cele mai multe ori, şi unele secvenţe care descriu tradiţiile săteşti, cu imagini încărcate de pitoresc şi nostalgie. Astfel, împletirea armonioasă a întâmplărilor din copilărie cu sărbătorile sau ordonarea cronologică a evenimentelor prin prisma zilelor de sărbătoare respectate tradiţional în popor caracterizează coloritul epocii şi natura psihologică a personajelor crengiene.

Totodată, înregistrăm şi termeni bisericeşti, care apar cu diverse intenţii stilistico-pragmatice în unele pasaje ca: din băţul în care era aşezată fila cu cruce-ajută şi buchile scrise de bădița Vasile pentru fiecare, am ajuns la trătaji, de la trătaji la ceaslov, ş-apoi, dă, Doamne, bine! în lipsa părintelui şi a dascălului întram în ţinterim, țineam ceaslovul deschis şi, cum erau filele cam unse, trăgeau muştele şi bondarii la ele, şi, când clămpăneam ceaslovul, câte zece-douăzeci de suflete prăpădeam deodată; potop era pe capul muştelor!; Iar părintele, ba azi, ba mâne, aducând pitaci şi colaci din biserică, a împărţit la fiecare, de ne-a imblânzit, şi treaba mergea strună; băieţii schimbau tabla în toate zilele, şi sâmbăta procitanie - în toate aceste secvenţe de text, cu măiestrie artistică, naratorul îşi dezvăluie cunoştinţele şi sârguinţa în învăţătură, dar nestrunind spiritul jovial al copilului, gândul căruia era la cireşe, la scăldat sau la pupăza din tei.

La cele prezentate mai sus, am adăuga şi fragmentele: lainic de școlar; Şi când învătă eu la şcoală, mama învăța cu mine acasă şi citea acum la ceaslov, la psaltire şi Alexandria mai bine decât mine; a face cădelniță în biserică; a ține isonul; și dascăli, și popi, și vlădici; isonar al bisericii; stăriție, monahi, ieromonahi; Şi câte târnosiri şi sfinţiri de biserici din nou, şi câte soboare şi revizii de fețe bisericeşti şi politiceşti, şi câți străini din toată lumea, şi câte inimi purtate de dor, şi câte suflete zdrobite şi rătăcite n-au trecut prin satul nostru spre monăstiri!; s-a sfințit paraclisul, în care autorul enumeră activităţile unui şcolar sau prezintă ierarhia rangurilor bisericeşti. Ultimul enunţ amintit mai sus se remarcă, pe lângă termenii din sfera religioasă pe care-i conţine, printr-o expresivitate implicită, printr-un limbaj emotiv, artistic, cu referire la acei care căutau să-şi stingă dorurile rătăcind în trecere prin Humuleşti spre alte mănăstiri.

Dincolo de valorile stilistice imanente ale textului, de prezentarea ansamblului de caracteristici care formau coloritul local al satului, oralitatea şi jovialitatea crengiană derivă şi din mărcile singulare ce ţin de context, care edifică stilul crengian propriu-zis. Cu referire la cele menţionate mai sus, amintim că Iulian Costache identifică în scriitura crengiană o dublă interpretare: „recursul la un limbaj popular, cu ingrediente de oralitate şi specificitate locală moldovenească" (Costache, 2017, p. 20), adică o distanţare intenţionată de la norma literară, şi recursul la vocabularul pasiv al limbii, care „a pierdut” unele semnificații primare, ieșind din uzul comunităţii lingvistice.

Relevantă, în acest sens, ni se pare afirmaţia lui W. Labov (apud Gadet, 1992, p. 5-15) care susține că oamenii sunt în aceeași măsură sau chiar mai mult subiecte ascultătoare decât vorbitoare: noi ne formăm „competența eterogenă” prin confruntările noastre constante cu diferite produceri neunificate sau răzlețe. In acest context, precizăm că receptorul, cel care ascultă și recepționează o informație scrisă sau orală, reconstituie sensul în funcție de competența 


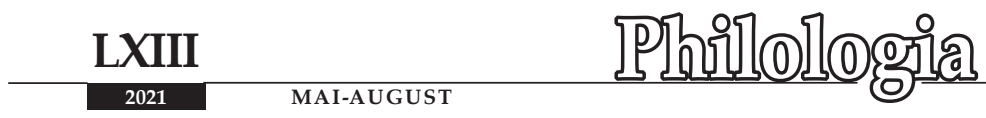

sa lingvistică, interpretându-l în baza trăirilor proprii. Efectuând o analiză a sensului, ca mecanism al variabilității individuale, L. Răciulă conchide că anume ,abordarea variabilității diafazice obligă la o interpretare a sensului în raport cu alte sensuri, sensul individual depinzând, astfel, de alte sensuri individuale" (Răciulă, 2010, p. 100). Aşadar, lingvista consideră că o comunicare, o idee care este proiectată spre un receptor, generează în mintea acestuia o altă idee sau un ,interpretant”, dacă e să utilizăm termenul propus de către autoare, care se constituie în limitele experienței umane a receptorului.

Prin urmare, în „Amintirile...” lui Creangă poţi să vezi exact ce e scris sau poţi decoda fiecare interpretare semantică, raportând cele narate, întâmplările şi aventurile lui Nică, la propria copilărie, la propriile trăiri, identificându-te, pe alocuri, cu naratorul sau cu alte personaje implicate în naraţiune. Suntem în acord cu afirmația lui Umberto Eco care susține că libertatea interpretativă a receptorului este ghidată de către autor, acesta urmărind ,,a ne insera în mod liber într-un univers care totuşi este întotdeauna cel voit de autor" (Eco, 1969, p. 44), unul elaborat în funcție de factorii motivaționali ai emițătorului. Astfel, orice text al emițătorului este elaborat printr-o manipulare dibace a expresiei, solicitând o anumită atitudine sau un anumit feedback din partea receptorului. Anume acest aspect diferențiază stilurile individuale ale autorilor, construind corelația dintre expresie și conținut, motivând alegerea unor variante combinatorii sintactice sau lexico-semantice în funcție de competențele lingvistice, psihologice și de creativitate ale autorului, dar, mai ales, de competentele de perceptie și de interpretare ale receptorului, cel care devine „manipulat”. În „Amintiri din copilărie”, Ion Creangă devine un „manipulator” excelent, care ilustrează cu măiestrie viața Humuleștiului și, printr-o serie de indici diafazici, intercalează cititorul în iureșul întâmplărilor copilăriei sale, făcându-l părtaș al propriilor gânduri, emoții și trăiri intense.

Din perspectiva dimensiunii variaţionale diafazice, „Amintiri din copilărie” este o naraţiune confesivă a trăirilor unui copil universal, ale copilului de la sat, din perioada când nu exista acest „boom” tehnologic şi când plictisul era învins prin ghiduşii şi pozne. Componentele esenţiale ale lucrării - oralitatea, umorul, jovialitatea, adevărurile epocii etc. - sunt prezentate de către autor printr-o construcţie estetică a frazelor, prin joc de cuvinte şi sensuri, abilitate crengiană, pe care o sesizează și Vl. Streinu: „Scriitor și actor totodată, fraza lui e bineînțeles scrisă, dar este mai ales jucată vocal pe un registru de intonații, în cuprinsul cắruia cuvintele pot căpăta chiar sensuri contrare. Ca în limbile extrem-orientale unde cuvintele au atâtea înțelesuri câți moduli de intonație li se aplică, glasul povestașului moldovan e plin de asemenea «semanteme» (cum le spun lingviștii) nescriptice, și ele singure îi susțin identitatea" (Vianu, Cioculescu, Constantinescu, Streinu, 2009, p. 177).

Indici ai variaţiei diafazice în opera crengiană „Amintiri din copilărie” sunt diversele structuri unitare fuzionate în text, care constituie nişte ,transfigurări frazeologice” - „schimbarea unui element component” (Molea, 2015, p. 36) pentru a obţine o semnificaţie retorico-pragmatică, de ironizare sau pentru a reda o atitudine zeflemitoare: înaintat în învățătură până la genunchiul broaștei; blagoslovenia lui Nicolai, făcătorul de vânătăi; Logofete, brânză-n cui, lapte 
acru-n călămări, chiu și vai prin buzunar!; Na-ți-o bună, că ți-am frânt-o sau crearea unor unităţi lexicale proprii: ai trecut de bucheludeazla și bucherițazdra ş. a. Astfel, prin construirea dibace a acestor structuri lexicale, Ion Creangă re-inventează semnificaţiile, atribuind cuvintelor sensuri noi şi diverse valori pragmatico-stilistice ale ilarului.

În alte exemple ne delectăm cu structuri modificate sau cu expresii frazeologice profunde din punct de vedere conţinutal şi expresiv precum: a mâncat papară; $a$-și face felul (a-și face de cap); începe a ne pofti pe fiecare la Bălan; a găti de ascultat; a o lua la sănătoasa; a se lua de la școală (a se învoi); fugeam de rupeam omătul; a boscorodi cu cimilitura - toate acestea contribuind la nuanțarea semantică a enunţurilor şi la amplificarea valenţelor spiritului popular crengian.

Relevantă ni se pare şi utilizarea unui flux de construcţii lexicale cu rol de metaforă sau comparaţie: Plângea de sărea cămeșa de pe dânsa (plângea în hohote); ne mângâia cu Sfântul Nicolai (îi bătea, îi pedepsea prin aplicarea unor lovituri de bici); a trage o bleandă (a împinge); mă uitam pe furiș la ușa mântuirii (avea intenţii de evadare); altă făină se macină acum la moară (altfel stau lucrurile); am dogorit obrazul părintelui de ruşine (a-1 face pe părinte să-i fie foarte ruşine de ucenicii săi); nu fă vorbă ca fariseul cel fățarnic. Bate-te mai bine peste gură și zi ca vameșul: Doamne, milostiv fii mie, păcătoasei, care-mi tot înbălorez gura pe bărbat degeaba (în care, prin exemplul fariseului şi al vameşului, sunt evocate personajele biblice cu care, în opinia tatălui, se identifică părinţii copilului Nică); m-am azvârlit fără sine pe părul unui cal (a încăleca în grabă); s-o luăm de-a chioara (a merge în neştire, a rătăci) etc.

O trăsătură lexicală importantă este atestarea unui număr extrem de redus de neologisme, care nu poate fi motivată decât prin excluderea conştientă şi intenţionată a acestora de către autor pentru a păstra caracterul popular al naraţiunii sau, cum am menţionat şi anterior, prin prisma unor factori motivaţionali, urmărind finalitatea de a ghida manipulativ cititorul spre o anumită interpretare a textului.

În concluzie, călătorind a nu ştiu câta oară printre „Amintirile” lui Ion Creangă, ne-am delectat cu un lexic variat şi, în cea mai mare măsură, marcat stilistic, prin care autorul povesteşte întâmplări senine, încărcate de căldură şi nostalgie, redate prin construcţii lexicale de factură populară, sugerându-ne diverse stări de spirit: de la haz şi voie bună până la dor şi beatitudine. Nota definitorie a operei lui Ion Creangă rămâne a fi îmbinarea sui generis a umorului şi a sentimentalității, acestea fiind redate printr-o varietate bogată de forme şi mijloace de expresie, menite a ne „teleporta” în viaţa Humuleştiului de odinioară.

\section{Referințe bibliografice:}

BAHNARU, Vasile. Limba prozei lui Spiridon Vangheli - Caracteristici functionalstilistice. În: Philologia. 2013a, LV, p. 9-22 [online]. Disponibil: https://ibn.idsi.md/ sites/default/files/imag_file/Limba\%20poeziei\%20lui\%20Spiridon\%20Vangheli_ caracteristici\%20functional\%20stilistice.pdf [citat 12.03.2020].

BAHNARU, Vasile (red. resp.). Lexicologia practică a limbii române. Chişinău: Profesional Service, $2013 b$. 
COSTACHE, Iulian. Introducere. În: DUMITRESCU-BUŞULENGA, Zoe. Ion Creangă. Putna: Editura Nicodim Caligraful, 2017.

DUMITRESCU-BUŞULENGA, Z., Ion Creangă. Putna: Editura Nicodim Caligraful, 2017.

ECO, Umberto. Opera deschisă: Formă şi indeterminare în poeticile contemporane. Trad. C. M. Ionescu, București: Editura pentru Literatură, 1969.

GADET, Françoise. Variation et hétérogénéité. În: Langages. $26^{\mathrm{e}}$ année, $\mathrm{n}^{\circ} 108$, Hétérogénéité et variation: Labov, un bilan, sous la direction de Françoise Gadet. Paris: Larousse, 1992. p. 5-15 [online]. Disponibil: https://www.persee.fr/doc/lgge_0458726x_1992_num_26_108_1647\# [citat 15.03.2017].

MOLEA, Viorica. Revalorificarea tezaurului frazeologic în textul publicistic actual. În: Studia Universitatis Moldaviae (Seria Ştiinţe Umanistice). 2015, nr. 10(90), p. 32-38.

MOLEA, Viorica. Valorificarea expresiv-estetică a oralităţii în creaţia lui Ion Creangă. În: Limba Română. 2018, nr. 7-8 (249-250), p. 161-169.

OLARIU, Florin-Teodor. Variație și varietăți în limba română. Studii de dialectologie și sociolingvistică. Iași: Editura Institutul European, 2017.

RĂCIULĂ, Lilia. Variabilitatea diafazică în cadrul unor serii stilistico-istorice. Chişinău: Bons Offices, 2010.

VIANU, Tudor, CIOCULESCU, Șerban, CONSTANTINESCU, Pompiliu, STREINU, Vladimir. Ion Creangă. Metafora umorului. Iași: Princeps Edit, 2009.

Notă: Articolul a fost realizat în cadrul proiectului de cercetare 20.80009.1606.01 Valorificarea științifică a patrimoniului lingvistic național în contextul integrării europene, Institutul de Filologie Română „B. P.-Hasdeu” al MECC. 


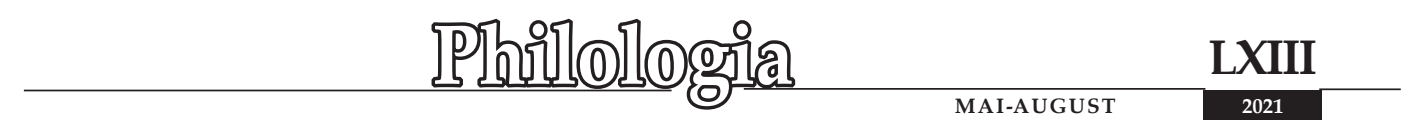

https://doi.org/10.52505/1857-4300.2021.2(314).11

CZU:811.135.1'373.45

\title{
ENGLEZISME RECENTE - DIN UZ ÎN DICT⿻IONAR
}

\author{
LIVIA CARUNTU-CARAMAN \\ Doctor în filologie \\ E-mail: liviacaraman@yahoo.com \\ ORCID: https://orcid.org/0000-0001-6829-6440 \\ Institutul de Filologie Română „Bogdan Petriceicu-Hasdeu” (Chișinău) \\ Recent Anglicisms - from use in the Dictionary
}

\begin{abstract}
In contemporaneity, the English language successfully fulfills the role of a mediator in international communication, deeply influencing the other languages, including Romanian. Through the realities of the brand made in the Anglo-American space, which are propagating inventively in all four parts of the world, penetrate in the local vocabulary and their names, being assimilated and used in internal daily expression. The given words, called Anglicisms, cause inaccuracies among both users and researchers.

In order to solve some of the problems, we propose the design of a small dictionary, in which to collect all the recent Anglicisms from our use in order to be subjected, from scholarly positions, to a regulated interpretation that will become an obligatory norm to follow. The language consumer should consult here spelling and morphological values, pronunciation and stress, decoding of abbreviations and etymology, semantic definitions and practical examples.

Finally, the Anglicisms, which have previously confused the speaker, to be scientifically processed, elucidated and returned to the public.

Keywords: globalization, communication, influence, vocabulary, Anglicism, dictionary, spelling, pronunciation, etymology, semantics.

\section{Rezumat}

În etapa contemporană, limba engleză își îndeplinește cu succes rolul de mediator în comunicarea internațională, influențând profund celelalte limbi, printre care și româna. Prin intermediul realităților marca made in spațiul anglo-american, care se propagă inventiv în toate cele patru părți ale lumii, pătrund în vocabularul local și denumirile acestora, fiind asimilate și întrebuințate în exprimarea cotidiană internă. Cuvintele date, numite englezisme, provoacă inadvertențe atât printre utilizatori, cât și printre cercetători.

Pentru a soluționa unele din probleme, propunem elaborarea unui mic dicționar, în care să fie colectate toate englezismele recente din uzul nostru ca să fie supuse, de pe poziții savante, unei interpretări reglementate ce va deveni normă
\end{abstract}




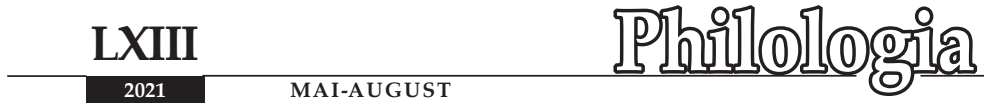

obligatoriu de respectat. Consumatorul de limbă să consulte aici ortografie și valori morfologice, pronunție și accentuare, decodarea abrevierilor și etimologie, definiții semantice și exemple practice.

În fine, englezismele, care derutau vorbitorul, să fie procesate științific şi întoarse înapoi publicului, elucidate și necesare.

Cuvinte-cheie: globalizare, comunicare, influență, lexic, englezism, dicționar, ortografie, pronunție, etimologie, semantică.

La etapa contemporană, omenirea se angajează tot mai dinamic într-un proces complex de globalizare, ceea ce duce la o apropiere benefică între popoare. Pentru ca această diversitate polidimensională de trai, de comportament, de activitate să-și poată mai lesne atinge obiectivul, e necesar să desfășoare o colaborare multilaterală. Astfel, se încheie tranzacții economice interstatale, se semnează acorduri politice între diferite sisteme, au loc interferențe între culturile lumii. Ceea ce inițial este un produs național, ajunge să fie o utilitate a multor națiuni. Iar comunicarea, în acest conglomerat social-uman în continuu progres, devine una din părțile componente de bază ale succesului.

Și cum mijlocul principal de comunicare între oameni este limba, iese în evidență imperativul de a determina glotonimul aceleia care să-și asume rolul de intermediar în această relaționare eterogenă. Era logic, și așa s-a și întâmplat, ca să-și autopropulseze serviciile funcționale în circulația internațională limba unor națiuni mai puternic dezvoltate, care, grație nivelului tehnico-științific avansat, produc noi și noi bunuri materiale și spirituale, implicit își renovează concomitent și propriul vocabular, iar producția, utilă și cu cerere pe piața mondială, se distribuie în toate cele patru puncte cardinale, însoțită de denumirile primite la ieșirea de pe rampa conveierului, încetățenindu-se și adaptându-se în noile ambianțe de aplicativitate.

În așa mod, limba engleză, maternă în două dintre cele mai dezvoltate state ale lumii, devine vorbită, în măsură mai mare sau mai mică, în toate țările. Mai mult, implantându-și realități și noțiuni în destinul altor popoare, printre care și cel român, își exercită o influență impunătoare asupra limbilor acestora, ducând la perturbații importante în lexic, îmbogățindu-1 și internaționalizându-1, dar și punându-i în gardă pe mulți lingviști care atenționează asupra unui potențial pericol de poluare a caracterului național al limbilor.

E de la sine înțeles că invadarea unor elemente străine în viața cotidiană a unui neam stârnește diverse reactiii de suspiciune printre concetătenii săi. Depinde de gust, de agreabilitate generată de formă sau eufonie, de necesitate, de anturaj. Așa s-a întâmplat întotdeauna și limbile multor popoare s-au amestecat cu altele, încât nu există limbi pure. Chiar engleza, care își afișează cu superioritate rolul de hegemon în comunicarea internațională, nici pe departe nu este o limbă pură. Ea conține o mulțime de termeni împrumutaţi din exterior, începând cu cei latini, pătrunși în perioada antică de dominare a romanilor, urmând cu termenii din franceza veche, apoi cei veniţi prin intermediul limbii franceze moderne ca rezultat al contactelor 
firești de vecinătate. În urma colonizărilor, în engleză au pătruns o serie de cuvinte exotice din la fel de exoticele limbi vorbite în teritoriile ocupate de britanici.

La fel și limba română a trecut în evoluția sa prin imixtiuni însușindu-și slavonisme, grecisme, turcisme, maghiarisme. Unele și-au lăsat durabil amprenta asupra lexicului nostru, fiind utilizate și azi, altele s-au pierdut în neant odată cu dispariția realităților pe care le-au desemnat. Iar modernizarea ei s-a produs sub influenţa limbii franceze la mijlocul sec. al XIX-lea, prin constituirea noului vocabular din cuvinte de origine franceză, renovându-şi astfel vocabularul cu împrumuturi însemnate făcute din această limbă. Și limba română s-a dovedit receptivă la toate aceste schimbări: când a simțit nevoia le-a acceptat, când a trebuit a eliminat din uz orice lexem inutil, deservind cu fidelitate utilizatorii săi.

În prezent limbii engleze i-a venit rândul să-și demonstreze forța de penetrare în funcțiile organizatorice ale limbii române. Și limba română a sesizat conjunctura actuală din lumea limbilor, consimțind, prin vorbitorii săi, modificările considerabile de vocabular înaintate de limba engleză prin realitățile implementate în viața de zi cu zi. Aceste metamorfoze rămân totuși niște imixtiuni, dar necesare. $\mathrm{O}$ cere timpul și românul e antrenat și el în acțiunea de globalizare pentru a fi în rând cu lumea civilizată, pentru a se integra în comunicarea internațională. Or, pentru momentul acesta concret, invazia cuvintelor de origine engleză, numite englezisme (de la denumirea limbii engleză - englezism), constituie un mijloc ieftin și lejer de îmbogățire a vocabularului, un prilej prielnic de internaționalizare a lui.

Și întrucât acest fenomen de englezizare (Caruntu-Caraman, 2017, p. 48) este în desfășurare ineluctabilă, suspiciunile specialiștilor de resort privind probabilitatea unui risc de impurificare a exprimării trebuie risipite. E de datoria savanților să-1 țină sub control, să-1 analizeze și să-l îndrepte pe o cale cât mai compatibilă de ajustare și armonizare a englezismelor în comunicare; să-i permită limbii să decidă cum şi cât să-l consimtă.

Anume din considerentul că în actualitate limba engleză este și continuă să fie o influență internațională destul de puternică pentru o perioadă îndelungată, autori versați vorbesc despre aceasta în termenii unei mondializări lingvistice generate de ritmurile alerte ale contactelor economice, politice, sociale și culturale ale secolului XXI. Astfel, dacă e să ne referim la englezisme, vom susţine că ele au fost și rămân în centrul cercetărilor lexicologice, provocând variate opinii.

Pe de o parte, menționăm efortul lăudabil și curajos, dar și patriotic al aderenților orientării puriste, care s-au ridicat vehement în apărarea purității limbilor lor. Asemenea reacții s-au manifestat pretutindeni, întrucât „La Paris, Roma, Berlin sau Atena sunt tot atâtea firme scrise în engleză sau în pseudoengleză ca și la noi, iar cuvintele împrumutate în limbile respective sunt cam aceleași" (Avram, 1997, p. 8). Însă o dârzenie mai ferventă s-a accentuat în Franţa, unde personalități marcante au condamnat aprig invaziunea englezismelor în limba franceză. Savantul R. Étiemble a lansat termenul „franglais” pentru ,a desemna idiomul hibrid rezultat din împestrițarea francezei cu anumite cuvinte, frazeologisme și elemente de compunere anglo-americane" (Stoichițoiu-Ichim, 2007, p. 84). Iar profesorul F. de Grand-Combe consideră anglomania „o rătăcire deplorabilă și antipatriotică”, o manifestare din sfera ,patologiei mentale”, având drept principală 


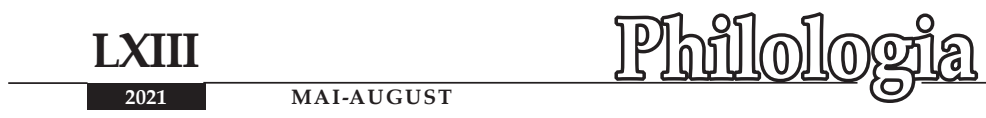

cauză „veleitarismul intelectual” (ibidem). Și s-a culminat cu propuneri legislative și măsuri oficiale prin care li se interzicea vorbitorilor să folosească englezismele în public, neaprobate în anumite inventare, iar pentru realitătile recente (pe care totuși le acceptau) recomandau echivalente denotative deja existente sau nou create în limba franceză.

Voci răspicate menite să protejeze limbile naționale au răsunat și în alte țări. În Germania, Asociația Limbii Germane (Verein Deutsche Sprache - VDS) considera că limba germană, dacă nu se iau măsuri urgente pentru a o proteja de invaziile străine, ar putea deveni ,periferică” și s-ar transforma într-un idiom peiorativ „Denglisch” (Wikipedia). In Spania, „la plaga de los anglicismos” (J. Mallo) era percepută ca ceva dăunător și inutil, care îndrepta limba spaniolă spre un idiom hibrid - „(e)spanglish” sau ,englañol” (Mateescu, 2014). Belgienii vorbeau despre un ,anglovirus”, iar canadienii (R. Georgin) considerau influența engleză asupra limbii franceze din Québec o amenințare care durează mai bine de un secol (Radu, 2007). Și în România G. Pruteanu a stigmatizat „,romgleza”, invocând ca să fie stopată „,cocalizarea” limbii române (Stoichițoiu-Ichim, 2007, p. 84).

Dar, după cum s-au derulat evenimentele în continuare, în pofida argumentelor logice și firești (deși, fără îndoială, râvna puriștilor și-a avut efectul său), atitudinea de zădărnicire a înrâuririlor engleze a fost anihilată. Englezismele, purtate de realizările ,invadatoare”, care au pus stăpânire pe viața cotidiană, și-au adeverit viabilitatea. Au pătruns în vorbire, au cucerit vorbitorii și s-au încorporat în lexicul limbilor, iar mai apoi le-au acceptat și specialiștii.

Pe de altă parte, evidențiem unele investigații ale adepților care acceptă englezismele și văd în fenomenul dat un imperativ al vremii în comunicare, lansând proiecte internaționale edificatoare: Proiectul European de cercetare „Elementul englez în limbile europene”, condus de Rudolf Filipović (Filipović, 1982); Proiectul internațional coordonat de profesorul Manfred Görlach, destinat să reflecte efectul influenței limbii engleze în lexicul a 16 limbi europene contemporane, inclusiv limba română, din care au rezultat un dicționar al englezismelor europene „A Dictionary of European Anglicisms, 2001”, un volum de studii „English in Europe, 2002” și un volum de bibliografie „An Annotated Bibliography of European Anglicisms, 2002” (Zafiu, 2002).

Cei mai mulți dintre cercetătorii români (Th. Hristea, M. Avram, G. Ciobanu, A. Stoichițoiu-Ichim ș.a.) se afiliază opiniilor majoritare din spectrul lingvistic european referitor la problema englezismelor și a influențelor engleze, recunoscând, în lucrările lor, că fenomenul în cauză există și în limba română, că e foarte activ, penetrant, iminent. Având în față experiența internațională, dar și pe cea specific românească, au demonstrat mai multă permisivitate în abordare și au relevat soluții conforme pentru a include în vorbirea noastră unități complet de altă natură, distincte din diverse puncte de vedere: filologic, geografic, psihologic, oferindu-le posibilităţi modificative reglementate și mediu pe măsură pentru utilizare corectă și liberă.

Preocupați de aspectul strict lingvistic al penetrării englezismelor în limba română, autorii au determinat numitorii comuni - ,etimologia, căile de pătrundere, sferele de circulație, adaptarea grafică, fonetică și morfologică, 
modul de înregistrare în dicționare" (Stoichițoiu-Ichim, 2007, p. 85) - care trebuie analizați și subordonați reformării și care, în caz oportun de flexionare, să fie suprimați (afixele englezești) sau suplimentați (afixele românești), pentru ca formele modelate să se includă certamente în circuit și să fie identificate drept lexeme românești cu valabilitate deplină.

În așa mod, în urma unor cercetări sistematice teoretice și practice, valoarea englezismelor în limba română (ca și a celorlalte împrumuturi lexicale, la momentul lor istorico-lingvistic) s-a demonstrat a fi incontestabilă: substituie unitățile învechite, epurând vocabularul de elementele uzate; îl renovează, denumind adevăruri materiale și spirituale recent pătrunse în uz; contribuie la acumularea și diversificarea mijloacelor de exprimare, amplificând latitudinea de selecție a arsenalului sinonimic de redare; modernizează însăși limba, incluzând-o în circuitul internațional printr-un însemnat segment de lexic, comun și înțeles în multe limbi ale lumii.

În această ordine de idei, nuanțăm raționamentul că fenomenul englezismelor este favorabil limbii române. În susținere vin argumentele de rigoare prezentate de specialiști în materie, dar și de alte personalități ale științei și culturii românești, care au contribuit la îmbogățirea potențialului de exprimare prin acceptarea și includerea elementelor străine ce au dus la evoluția calitativă a tezaurului nostru lexical.

Așadar, pătrunderea și utilizarea curentă a englezismelor în limba română este o manifestare firească. Dinamismul lor este probant și avansează în mod progresiv. Din necesitatea de a desemna noianul de realități recente, apar noi și noi englezisme. Unele, mai puține la număr, se comportă literal ca în limba de origine (card, modem), întru totul asemănătoare cu structuri neaoșe ale cuvintelor românești și e ușor să le reții atât forma, cât și rostirea. Altele însă, cele mai numeroase, ori se aseamănă după aspectul structural, dar cer o pronunție cu totul diferită (mall - mol, musical - miuzicăl), ori diferă și după formă, și după pronunțare (mouse maus; byte - bait), provocând dificultăți și la memorizare, și la recunoaștere, și la întrebuințare. Apar confuzii și în situaţiile când englezismele necesită a fi supuse flexionării sau exprimă semnificații și nuanțe semantice înnoite. Ele erup în vorbire sau în lectură inopinat, ca niște necunoscute neinvitate care împiedică perceperea mesajului transmis de text.

Aceste inadvertențe, dar și altele, se întâlnesc frecvent și la vorbitorii de rând. Cititorii surselor mass-media, mai multe categorii de utilizatori au nevoie de ajutor. În asemenea cazuri, binevenită este consultarea dicționarului, unde se identifică norme ortografice, forme gramaticale, modele de pronunție, explicarea sensurilor și a nuantelor de sens, mostre de aplicare.

Însă există cazuri când unii termeni nu se găsesc în dicționar din simplul motiv că sunt mai recenți și n-au fost încă înregistrați. Se întâmplă aceasta, mai întâi, pentru că „avalanșa de anglicisme” (Stoichițoiu-Ichim, 2007, p. 83) și perioada foarte scurtă de încadrare a acestora în comunicare pune în dificultate mecanismele limbii pentru a le procesa în ritm normal și a le lansa în funcție conform reglementărilor sale, cum a făcut-o cu unele pe parcurs de zeci sau chiar sute de ani (miting, fotbal), de aceea multe rămân în afara cadrului normativ și scot în evidență neajunsuri care pot aduce prejudicii limbii române înseși, specificului și purității ei, iar lexicologii 


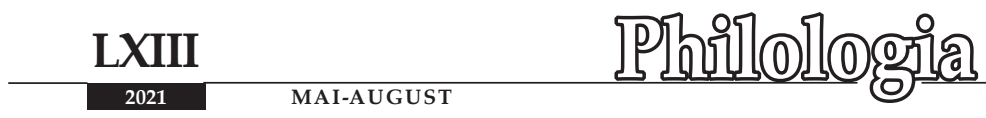

nu prea izbutesc, din mai multe considerente, să le includă în glosare. Nu se pot edita dicționare în fiecare an.

În al doilea rând, dezvoltarea rapidă a vocabularului românesc, determinată de pătrunderea intensivă a englezismelor, nu permite specialiștilor în domeniu să țină prompt pasul cu ritmul lui de îmbogățire, ,lucrările lexicografice existente nu reușesc să reflecte în mod adecvat un fenomen atât de dinamic și multiform cum este influența engleză" (idem, 2001, p. 7).

Desigur, multe dintre englezismele care circulă cu o frecvență impresionantă în vorbire, în mass-media și în alte domenii ar putea părea, la o primă vedere, ca fiind de prisos, fără nici un avantaj, însă în viața reală, de cele mai multe ori, se dovedesc a fi utile. Datorită acestui fapt, majoritatea articolelor de presă și cele specializate permit utilizarea englezismelor, chiar și a celor neatestate în dicționare cu scopul de a preciza mai bine sensul, de a evita monotonia lexicală, repetarea cuvintelor de același fel, respectând laconismul și exactitatea exprimării și redând în mod real faptele prezentate. De aceea, trebuie să le admitem și noi și să lăsăm uzul să le hotărască soarta: care să fie menținute și care să fie uitate. Aşa că e nevoie să le înmagazinăm într-un dicționar de specialitate pe cele mai noi și relativ noi, iar celor mai vechi să le completăm sensurile adiționate pe parcurs și să le constatăm schimbările de ordin morfologic, ortografic și ortoepic. Ca urmare, englezismele să poată fi consultate şi apoi utilizate corect şi adecvat.

Ideea că dicționarele par întotdeauna incomplete, pentru că sunt ,depășite de bogăția și complexitatea faptelor existente în limbă”, este dezvoltată și de cercetătorul F. Kiraly (Kiraly, 1990, p. 48). Iar Th. Hristea complinește că „dicționarele noastre uzuale şi mai ales DOOM-ul ar trebui să înregistreze cât mai multe dintre neologismele recente și foarte recente, chiar dacă prin aceasta ar provoca reacții negative din partea unor puriști întârziați”" (Hristea, 1995, p. 52).

Această necesitate a fost susținută și de alți lingviști de-a lungul timpului. „Englezismele trebuie înregistrate în dicționare, întrucât folosirea lor nu poate fi împiedicată" (Athu, 2006, p. 41). Autoarea mai precizează că problema nu poate fi ignorată, deoarece lasă loc eventualelor greșeli, iar ca acestea să fie cât mai puține sau chiar să nu se mai producă deloc, ar fi preferat să se înregistreze și formulele originare din limba engleză pentru a sugera căi și mijloace de adaptare a lor în limba română.

Mai mult ca atât, autorizarea înregistrării tuturor inovațiilor lexicale pătrunse în uzul actual se va justifica, raportându-se la normele limbii literare pentru a identifica și analiza posibilele abateri și erori, întrucât doar „uzul determină în ultimă instanță încetățenirea propriu-zisă în limba noastră a cuvintelor străine" (Dumbrăveanu, 1999, p. 138), inclusiv a englezismelor. Numai circulația termenilor urmează să aleagă forma care se va încetățeni şi va fi fixată în dicționar, unde se va legifera și se va întoarce reglementată înapoi în comunicare.

Odată cu trecerea timpului, multe dintre englezismele care se răspândesc cu repeziciune în prezent, își vor găsi cadrul corespunzător de întrebuințare și se vor alătura stocului de cuvinte deja existent. Vor persista în limbă acele englezisme care 
vor fi acceptate și adaptate. Dinamica lor nu va fi recomandată de Academie, de cercetători, ci de necesitatea uzului lor în timp.

Dat fiind faptul că englezismele sunt numeroase, e de datoria noastră să revenim mereu asupra lor, fiindcă acest fenomen este practic inepuizabil. Toți termenii de origine engleză apăruţi anterior sau pătrunşi recent în limba română merită să fie supuși unor cercetări complexe atât sub aspectul cultivării limbii, cât și al necesității utilității acestora în domeniile/ scrierile specializate, dar și în limbajul oral.

Așadar, pornind de la exigențele dictate de utilizatori, privind receptivitatea neologismelor de sorginte engleză și dificultățile provocate de acestea în uz, dar și de la evaluarea aserțiunilor unor lingviști cu renume referitoare la acest act (expuse în rândurile de mai sus), am decis să selectăm toate englezismele întâlnite pe parcursul cercetării și să le depozităm într-un mic dicționar special. Corpusul examinat în producția de față va fi constituit din elemente excerptate din presa scrisă și audiovizuală a ultimilor ani, de pe firme și inscripții stradale, dar și din dicționarele generale, ortografice, explicative și de cuvinte și sensuri recente. Utilitatea identificării, înregistrării și analizei acestora a fost demonstrată și vom deține o sursă (considerăm noi) valoroasă, de încredere și accesibilă pentru fiecare, unde se vor regăsi termenii solicitați pentru a le verifica formele corecte de rostire și scriere. Lucrarea este deja în curs de elaborare la Centrul de Lingvistică, în cadrul proiectului Valorificarea științifică a patrimoniului lingvistic național în contextul integrării europene, subtema Cercetarea și valorificarea lexicului limbii române în context general românesc.

În concluzie, menționăm încă o dată că, în plan practic, Dicționarul de englezisme recente va avea un rol apreciabil în asimilarea termenilor englezi, având caracter explicativ și normativ. Acele cuvinte care se referă la aspecte indispensabile activității cotidiene, fiind frecvent întrebuințate, au șanse definitive să se mențină în limbă și să reziste în timp, iar cele mai neînsemnate, ocazionale, se vor manifesta episodic, vor avea o existență efemeră și vor dispărea, fiind date uitării.

Astfel, valabilitatea englezismelor se va confirma de la sine, vor trece testul timpului și al necesității, vor avea priză la public și se vor integra în vocabularul limbii române. Un loc meritoriu în acest proces sperăm să-1 dețină și dicționarul nostru, care înregistrează englezismele recente din iureșul vorbirii, le dotează cu aspect și comportament savant românesc și le întoarce, în plenitudine funcțională, înapoi la vorbitor.

\section{Referințe bibliografice:}

ATHU, Cristina. Neologismele din engleză în perspectiva lucrărilor normative DOOM și DOOM². În: Limba română, București, 2006, nr. 1-2, p. 41-52.

AVRAM, Mioara. Anglicismele în limba română actuală. București: Ed. Academiei Române, 1997.

CARUNTU-CARAMAN, Livia. Englezismele în presa periodică din Republica Moldova (aspectele funcțional, fonetic, ortografic, morfologic, semantic): teză de doctor în filologie. Chișinău, 2017. 


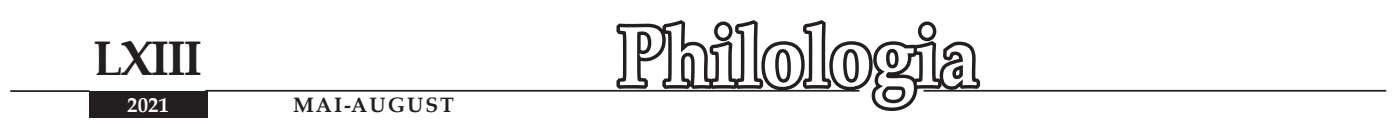

DĂNILĂ, Andrei, TAMBA, Elena. Dicționar de cuvinte și sensuri recente. București: Litera, 2014.

DEXI = Dicționar explicativ ilustrat al limbii române. Chișinău: Ed. Arc, 2007.

DUMBRĂVEANU, Albina, DUMBRĂVEANU, Ion. Considerente privind expansiunea și utilizarea unor anglicisme în limba română. În: Limba română, 1999, nr. 1, p. 135-138.

FILIPOVIĆ, Rudolf. Can a dictionary of -isms be an etimological dictionary? [online citat 10.03.2021]. Disponibil: https://www.euralex.org/elx_proceedings/Euralex 1983/013_Rudolf\%20Filipovic\%20\%20(Zagreb)\%20-\%20Can\%20a\%20dictionary\%20 of\%20-isms\%20be\%20an\%20Etymological\%20Dictionary.pdf [citat 10.03.2021].

HRISTEA, Theodor. Ortografia și ortoepia neologismelor românești (cu specială referire la împrumuturile recente). În: Limbă și Literatură. Vol. II. București: Societatea de Științe filologice din România, 1995, p. 36-54.

MATEESCU, Mihaela. Los Anglicismos en el diccionario de americanismos de la Asociation de Academias de la Lengua Española: Apreciaciones sobre su vitalidad. Universitatea din Pitești, 2014, p. 343-350 [online]. Disponibil: https://www.diacronia.ro/ ro/indexing/details/A14535/pdf p. 344 [citat 2.02.2021].

KIRALY, Francisc. Contacte lingvistice. Timișoara: Ed. Facla, 1990.

PĂCURARU, Veronica, UNGUREANU, Violeta, VULPE, Ana. Dicționar explicativ de cuvinte și sensuri noi. Chișinău: Pro Libra, 2016.

RADU, Voica. Influența internațională a limbii engleze. Cu privire specială la limbile romanice. Editura Mirton; Editura Amphora, 2007, p. 17-36 [online]. Disponibil: https://www.diacronia.ro/ro/indexing/details/A12869/pdf [citat 25.02.2021].

STOICHIȚOIU-ICHIM, Adriana. Observații privind semantica și stilistica anglicismelor în româna actuală (I). În: Limba și literatura română, 2001, nr. 3, p. 7-13.

STOICHIȚOIU-ICHIM, Adriana. Vocabularul limbii române actuale. Dinamicăl Influențe/ Creativitate. București: BIC ALL, 2007.

Wikipedia $=$ https://de.wikipedia.org/wiki/Verein_Deutsche_Sprache [online] [citat 3.03.2021].

ZAFIU, Rodica. Anglicismele în Europa. Din nou despre anglicisme [Manfred Görlach (ed.), A Dictionary of European Anglicisms. A Usage Dictionary of Anglicisms in Sixteen European Languages (DEA), Oxford, Oxford University Press, 2001; English in Europe, 2002; An Annotated Bibliography of 7 European Anglicisms, 2002]. În: România literară, 2002, nr. 37 şi 2002, nr. 38.

Notă: Articolul a fost realizat în cadrul proiectului de cercetare 20.80009.1606.01 Valorificarea științifică a patrimoniului lingvistic național în contextul integrării europene, Institutul de Filologie Română „B. P.-Hasdeu” al MECC. 


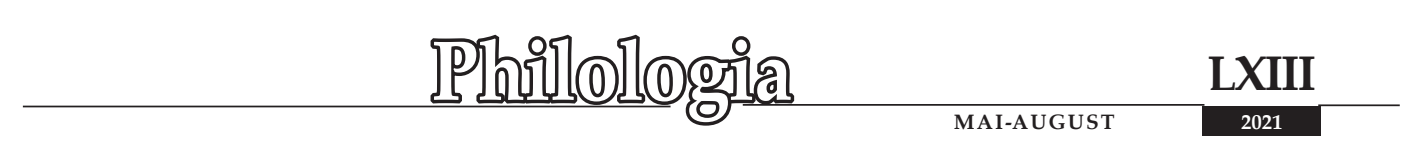

https://doi.org/10.52505/1857-4300.2021.2(314).12

CZU:811.135.1'374.2:373.46:61

\title{
REPERE MITOLOGICE ALE DUBLETELOR GRECO-LATINEȘI TERMINOLOGIA
}

\section{Eugenia MINCU}

Doctor habilitat în filologie, conferențiar universitar

E-mail: jana_mincu@yahoo.fr

ORCID: https://orcid.org/0000-0002-3774-2599

Institutul de Filologie Română „Bogdan Petriceicu-Hasdeu” (Chișinău)

\section{Mythological References of Greek and Latin Doublets and Terminology}

\begin{abstract}
The investigation of the process of establishing the Greco-Latin doublets implies the presence of mythological sources, which offer elucidations from the origin and are important in their semantic-functional design. In this article, we propose the analysis of the Greek-Latin doublet $<$ lat. umbilicus, $i, m$ and $<$ gr. omphalos, es, $f$,umbilical” (national and international dimensions), a representative doublet in medical terminology, but also modestly productive. Each of the components of the doublet requires personalized investigations (diachronic, synchronic aspects): the Latin component is included in the fundamental vocabulary of the Romanian languages (national terminology); Greek component - in the mass of vocabulary (international terminology). Neological lexical creations (formed on the basis of Greco-Latin doublets) correspond to a universal dimension of the conscious creativity of scientists and denominate specialized medical knowledge. medicine.

Keywords: Greek-Latin doublet, mythology, lexical creations, terminology,

\section{Rezumat}

Investigarea procesului de stabilire a dubletelor greco-latine presupune prezența surselor mitologice, care oferă elucidări ab origine și sunt puncte de reper în proiectarea semantico-funcțională a acestora. În prezentul articol propunem analiza dubletului greco-latin < lat. umbilicus, $i, m$ și < gr. omphalos, es, $f$,ombilic” (dimensiunile național și internațional), un dublet reprezentativ în terminologia medicală, dar, totodată, modest productiv. Fiecare dintre componentele dubletului solicită investigaţii (aspecte diacronic, sincronic) personalizate: componenta latină se include în vocabularul fundamental al limbii române (terminologia națională); componenta greacă - în masa vocabularului (terminologia internațională). Creaţiile lexicale neologice (formate în baza dubletelor greco-latine) corespund unei dimensiuni universale a creativităţii conştiente a savanţilor şi denumesc cunoştinţe specializate medicale.
\end{abstract}

Cuvinte-cheie: dublet greco-latin, mitologie, creații lexicale, terminologie, medicină. 
Introducere. Terminologia medicală românească reprezintă o simbioză a terminologiei medicale naţionale (formată în baza cuvintelor preluate din lexicul tradiţional autohton, supuse procesului de terminologizare) şi a celei internaţionale (axată pe lexiconul general internaţional). Creaţiile lexicale neologice (în baza dubletelor greco-latine) corespund unei dimensiuni universale a creativităţii conştiente a savanţilor şi denumesc cunoştinţe specializate, căpătate printr-o cunoaştere suplimentară a realităţii, având o utilizare cu predilecţie în limbajele specializate (în medicină formează, în special, terminologia clinică; se manifestă mai puțin în terminologia anatomică).

Dubletele greco-latine formează unităţi lexicale specializate, care, la rândul lor, în terminologia medicală acoperă funcţiile denominativă, reprezentativă şi de transmitere. Din punct de vedere pragmatic, acestea respectă principiile de utilizare, generate de următoarele condiţii pragmatice: a) respectă funcţia de bază a limbajului (comunicarea); b) presupune atitudinea subiectului faţă de hic et nunc; c) ia în considerare aria de utilizatori; d) acoperă imperativele situaţiilor comunicative; e) se pretează la maniera discursului.

Inventarierea dubletelor greco-latine, utilizate în terminologia medicală, a relevat: din totalul de $164(100 \%)$ de dublete greco-latine, $108(66 \%)$ denumesc segmente anatomice ale corpului uman, $41(24,4 \%)$ de dublete desemnează „lucruri” care se înscriu în terminologia clinică, $15(9,6 \%)$ dublete - în cea farmaceutică (Mincu, 2020, p. 56-58).

Dubletul greco-latin < lat. umbilicus, $i, m$ și < gr. omphalos, es, $f$,ombilic” denumește un segment anatomic al corpului uman, fiind atestat nu doar în terminologia anatomică, ci și în terminologia clinică.

Componenta latină a dubletului umbilicus, $\boldsymbol{i}, \boldsymbol{m}$ (suprimarea terminaţiei -us, rotacismul etc.) se află la originea cuvântului românesc buric, termen popular, inclus în vocabularul fundamental, dar și a termenului împrumutat din limba franceză ombilic, cuprins în masa vocabularului; ambii termeni desemnând ,orificiul abdominal prin care trece cordonul ombilical la fetus".

În Dicționarul de dublete etimologice ale limbii române (Gabinschi, 1998, p. 71) atestăm două evoluții ale latinescului umbilicus: 1) buric - moștenit din latină: lit. umbilicus; pop. umbulicus, cu un -us perceput ca articol nehotărât; 2) ombilic împrumut lat.-fr.; lat. umbilicus, împrumut din franceză (ombilic).

Dictionnaire étymologique de la langue française (Dauzat, 1938, p. 512) indică anul 1503 (G. de Chauliac), an de atestare a acestui termen, un cuvânt împrumutat din limba latină (< lat. umbilicus) (1490) și derivatele ombilical (1409), ombilique (1803).

Totuşi, la originea componentei latine umbilicus $i, m$ este cuvântul grec umbo, onis, $m$ care însemna ,proeminență în mijlocul scutului luptătorilor: aliquem umbone resupinare, care, la rândul lui, atestă variații semantice: „scut”: umbone se protegere; ,cot/ pumn”: cuntos umbone repellere; „pisc”: umbo Isthius; „piatră de hotar”: saxeus umbo; „togă” - umbo candidus etc. (Dvoretsky, 1976, p. 1042-1043).

Latinescul umbilicus este fidel polisemantismului, dezvoltându-l în expresii frazeologice. Cuvintele ombilic (med.); buric (med. pop.), cordon ombilical, 
centru, mijloc, jumătate sunt frecvente în expresii de tipul: dies ad umbilicus mortuus est/ ad. lit. ziua (ajunsă) la ombilic (la amiază) este moartă (pierdută); ad umbilicum adducerel ad lit. a fi adus până la ombilic (a finaliza, a duce la bun sfârșit); umbelicus in ventre medio/ ad lit. ombilic în mijlocul ventrului (proeminență centrală) etc. (ibidem).

In Letopisețele Țării Moldovei, lexemul buric nu este atestat.

$\mathrm{O}$ descriere a segmentului anatomic respectiv o oferă Pompei Samarian (1936, p. 225) făcând trimitere la Lexiconul slavo-român: „Pe peretele abdominal se găsește buricul. În Lexiconul Slavo-Roman, din 1649, termenul de buric se explica cu cuvântul găoace (< gr. Crețu. Lexicon Slavo-Român)". Apoi continuă: „Pravilistul bisericesc interpretând pe Hipocrat, spune că în timpul sarcinei copilul respiră prin buric [...] coconul acolo unde se află în mațul muerei [...] nu resuflă pre gură, ce pre buric (Bujoreanu, L c., g1. 13, p. 424)” (ibidem, p. 220). Forma articulată este cuprinsă în enunțul: „Buricu, când se umflă..." (ibidem, p. 333). scobitură".

Asocierea buric și găoace definește acest segment drept „gaură, loc gol,

În medicina populară, buricul semnifică însăși viața, conectând toate venele, ceea ce-1 face „,centru” al corpului uman. Cu valoare figurată, este prezent într-o serie de unități frazeologice: Copilul cu multe moașe rămâne cu buricul netăiat; a se crede buricul pământului etc.

Expresia frazeologică a se crede (sau a se socoti) buricul pământului înseamnă ,a se crede (sau a se socoti) cel mai important dintre toți”.

În accepția sa primară, buricul (centrul pământului) presupunea ,,punctul de plecare de la care liniile indică cele patru direcții sau punctele cardinale și împart orizontul în patru părți”. Ideea antică a ,buricului pământului” se găsește în multe culturi.

Mircea Eliade, în lucrarea sa Cosmologie şi alchimie babiloniană, oferă o sinteză a semnificației expresiei „buricul pământului” din perspectiva creației universale.

a) „Buricul pământului” este relaționat cu Paradisul:

„Paradisul, „,buricul pământului»,, era așezat, după tradiția siriană, pe un munte mai mare decât toți munții de pe pământ”' (Eliade, 1991, p. 26).

„... și Adam, și Lumea, sunt făcuți la «buricul pământului»” (ibidem, p. 28).

b) „Buricul pământului” este relaționat cu locul sacrificiului:

„După cartea siriană Peștera Comorilor, Adam a fost creat în centrul pământului, în același loc unde mai târziu s-a ridicat crucea lui Iisus" (ibidem, p. 27).

„În India, «locul sacrificiului» este adesea numit «buricul pământului», pentru că prin „,sacrificiu“" se susține Universul“, există ritmurile, viața, armonia” (ibidem, p. 30).

c) „Buricul pământului” este relaționat cu orașe, temple sacre:

„Valoarea mistică a unui oraș ca Ierusalim nu stă în faptul că este un oraș ceresc..., ci pentru că e considerat Centrul Lumi” (ibidem, p. 18).

d) „Buricul pământului” este relaționat cu omul (microuniversul): 
„Tehnicile ascetice indiene acordă o mare importanță „,buricului“; răsuflarea (aerul, ,fluidul vital“") trebuie dusă de la „buric“ la inimă; concentrarea yoghinică se face de cele mai multe ori în «buric»" (ibidem, p. 31).

e) „Buricul pământului” este relaționat cu cosmosul, creația universală (macrouniversul):

„... indienii, ca și mesopotamienii și celalte popoare orientale, concepeau «buricul pământului» drept adevăratul centru al Cosmosului” (ibidem, p. 73).

Sacralitatea (munte, templu, spirit etc.) presupune înălțime și înălțare și este condiția primordială a Axei Universului, a „Pomului vieții” care crește în centrul Lumii, în „Buricul Pământului”. Arborele Vieții asigură „ritmurile cosmice și viaţa se desfășoară începând de la „centru“ (ibidem, p. 29). Ideea de loc înalt, vârf se menţine în sintagma buricul degetului „vârful degetului”.

Cuvântul buric se atestă în mai multe denumiri de plante medicinale: buricul apei „plantă erbacee cu flori mici, albe sau roșietice”; buricul Venerei sau părulfetei; buricul-pământului sau muma-pădurii (Latharea squamaria); buricu-boului „plantă cu flori albe și multe rămurele, folosită în vindecarea tăieturilor” etc.

Terminologia medicală militează pentru termenul ombilic și pentru termenul-sintagmă cordon ombilical. Dicționarul lui Rusu (2010, p. 560) prezintă 4 termeni formați de la ombilic, dintre care 3 sunt derivați: substantivul ombilicare „adâncituri în formă de ombilic; procesul de formare a unei depresiuni, de formă asemănătoare ombilicului, în vârful unei papule"; paraombilical (localizare a herniei), adjectivul este arătat în relaţie de sinonimie cu paraomfalic și paraumbilical (< gr. para „lângă”) „,care se află situat în vecinătatea ombilicului"” (ibidem, p. 581); subombilical și, respectiv, subumbilical (< lat. sub „sub") „situat inferior de ombilic" (ibidem, p. 784). Al patrulea termen este format prin juxtapunere afixoidală: ombilicoportografie (< lat. umbilicus „buric” $+<$ lat. porta ,poartă” $+<$ gr. graphein ,a scrie”) „examen radiografic al sistemului port după injectarea unui produs de contrast iodat hidrosolubil, cu ajutorul unei sonde introduse la nivelul venei ombilicale, după denudarea și recanalizarea acesteia" (ibidem, p. 560).

Dicționarul rus-român oferă 8 termeni (Bejenaru, 1991, p. 80) pentru ombilic:

1. Termeni-sintagmă: ombilic cutanat, ombilic posterior etc.

2. Termeni formați prin afixoidare: a) element prim: ombiliform; b) element secund: spinoombilical.

Este o atestare care denotă statutul dublu al formanților afixoidali: prezența cuvântului autonom și, în același timp, parte integrantă a unui cuvânt compus.

Dicționarul lui Marcu explică și mai puțini termeni, doar 4 (2013, p. 688), menționând sinonimia cordon ombilical și cordon omfalic. Autorul dicționarului menționează un alt sens al termenului ombilic în sintagma ombilic glacial, folosit în geologie „parte a albiei subsăpate a unui ghețar, limitată în aval de contrapantă”.

Considerând cuvântul latinesc umbo, onis, $m$ aflat la originea cuvântului umbilicus, $i, m$ (de la care în română s-au format termenii buric și ombilic), constatăm o multiplă metaforizare: 
- umbo, onis, $m$,proeminență în mijlocul scutului luptătorilor” $\rightarrow$ umbilicus $\rightarrow$ buric (corpul uman)/ ombilic $\rightarrow$ găoace $\rightarrow$ gaurăa, loc gol, scobitură $\rightarrow$ adâncitură $\rightarrow$ depresiune $\rightarrow$ albie (parte a albiei) subsăpate;

- umbo, onis, $m$,proeminență în mijlocul scutului luptătorilor” $\rightarrow$ buric $\rightarrow$ centru/ jumătate;

- umbo, onis, $m$,proeminență în mijlocul scutului luptătorilor” $\rightarrow$ vârf $\rightarrow$ buric $\rightarrow$ umbilicus digiti $\rightarrow$ buricul/vârful degetului;

- umbo, onis, $m$,piatră de hotar” $\rightarrow$ saxeus umbo; aici sesizăm o corelare semantică cu grecescul omphalos ,piatră sacră”.

Referitor la componenta greacă a dubletului, în dicționarul lui Dvoretsky (1976, p. 704) atestăm următoarele: Omphale, es, $f$, cu trimitere la mitologie, și omphalos, $i, m$ a) „buric” (menționăm tendința de latinizare a cuvântului, pretarea la substantivele masculine); și b) „centru”, cu sens figurat.

Mitologia oferă mai multe explicații. Omphale este numele reginei Lidiei, al cărei sclav era eroul mitologic Herakle (devenit ulterior soțul ei); în cinstea soției sale, Herakle numește omphale cel mai ,adorat” segment al corpului reginei (https:// en.wikipedia.org/wiki/Omphale).

Conform aceleiași mitologii, omphalos-ul este „o piatră deghizată cu haine”. La nașterea lui Zeus, Rheia i-a oferit lui Chronos (care obișnuia să-și înghită nounăscuții) un omphalos; astfel, salvându-și fiul.

În cosmogonia greacă, Zeus a marcat centrul pământului cu un omphalos, indicând locul unde se află centrul pământului; punct în care haosul a dat ființă ordinii: omphalos devenind „piatra sacră” care aranjează timpul și spațiul și este o reprezentare simbolică a minții în lumea fizică (Burke, 1986, p. 30).

Dicționarul lui Arnaudov (1979, p. 305) stabilește o relație de sinonimie între substantivul omphalus, $i, m$ (menționăm faptul că lexemul deține deja o formă latinizată definitivă: $-u s,-i, m)$ și umbillicus, $i, m$ și prezintă pentru omphalus „buric” şapte termeni latinești, dintre care un termen este derivat (omphalitis, tidis, $f=<$ gr. omphalos „,buric” $+<$ gr. itis „,inflamație”,,inflamație a regiunii ombilicale"), iar alți şase termeni sunt formați prin juxtapunerea elementelor de origine savantă, înregistrându-se prezența modelului grec de formare a cuvintelor: omphalocele, es, $f$ (< gr. omphalos „,buric” + < gr. kele „,hernie”) ,hernie ombilicală”; omphalomesentericus, a, um (< gr. omphalos „buric” $+<$ gr. mesos ,la mijloc” $+<$ gr. enteron ,intestin”, „foiţă a peritoneului care leagă intestinul de peretele posterior al abdomenului, prapur"; omphalophlebitis, tidis, $f(<$ gr. omphalos „buric” $+<$ gr. phlebos „venă” + < gr. itis , inflamație”), termen care nu s-a păstrat; omphalorragia (< gr. omphalos „,buric” + < gr. rragia ,a curge”) ,hemoragie ombilicală” etc.

In calitate de afixoid, grecescul omphalos este susceptibil a fi ambipozițional: omfal(o)-, -omfal.

In dicționarul lui Nicolae Andrei (1987, p. 199), elementul secund -omfal este explicat drept „buric, ombilic”, dar și „,umflătură” - exemplele lipsesc. Pentru elementul omfal- omfalo-, dicționarul oferă nouă termeni: omfaloectomie $(<$ gr. omphalos „buric" $+<$ gr. ek ,în afară” $+<$ gr. tome „tăiere” $\rightarrow<$ gr. ektome + $-i a \rightarrow<$ gr. ektomia ,excizie” „excizie a ombilicului”); omfalotomie (< gr. omphalos „buric” + < gr. tome „tăiere” „tomie a ombilicului”) etc. 
Dicționarul lui Bejenaru explică 16 termeni (Bejenaru, 1991, p. 419), dintre care 3 sunt sintagmatici (se referă la omfalită gangrenoasă, purulentă, catarală), iar ceilalți sunt termeni formați prin afixoidare, termeni neatestați în alte dicționare: omfaloree, omfaloproptoză, omfaloflebită, omfaloflegmon etc.

Vom încerca să definim acești termeni (dicționarul prezintă doar traducerea în limba română, fără a oferi definițiile), în funcție de elementele terminologice adiacente:

- omfaloree $=<$ gr. omphalos „buric” $+<$ gr. rrheos „curgere” „secreții la nivel de ombilic";

- omfaloflebită $=<$ gr. omphalos ,buric” $+<$ gr. phlebos ,venă” $+<$ gr. itis „inflamație” ombilic” ,inflamație a venelor adiacente ombilicale”;

- omfaloflegmon $=<$ gr. omphalos „buric” $+<$ gr. phlegma „flegmă” „inflamație purulentă a țesutului subcutanat adiacent ombilicului”.

Posibilitatea definirii acestor termeni, fie și empirică, este determinată de elementele savante stratificate în timp, preponderent monosemantice; aspect decisiv în constituirea termenilor.

Valeriu Rusu definește 4 termeni pentru elementul prim omfal(o)- (2010, p. 559): omfalectomie, omfalită, omfalocel, omfalomezenteric și un termen-sintagmă canal omfalomezenteric echivalat cu sintagma canal ombilical (ibidem, p. 220).

În Dicționarul actualizat de neologisme (Marcu, 2013, p. 688) sunt definiți 10 termeni. Tot aici se atestă cuvântul autonom omfalos, ,piatră sacră folosită în templul lui Apolo din Delfi, care constituia centrul lumii” (ibidem).

Un prim semn al inițierii procesului de afixoidare este combinarea radicalului cu sufixul de origine greacă -itis, generându-se termenul omfalită.

Sunt atestați 16 termeni formați cu ajutorul prefixoidului terminologic omfal (o)„ombilic".

Având drept reper dicționarele nominalizate anterior, au fost delimitate două eșantioane semantice:

- Eșantionul 1 „ombilic”-omfaloragie, omfalotomie, omfalotrib, omfalotripsie etc. -15 termeni.

- Eșantionul 2 „sac vitelin” - omfalogeneză - 1 termen.

După cum vedem, elementul suportă devieri minore de la sensul de bază. Aceasta se explică prin fapyul că elementul terminologic desemnează un segment anatomic concret al corpului uman.

$\mathrm{Nu}$ au fost atestaţi termeni formați cu ajutorul sufixoidului terminologic -omfal „ombilic".

Totuși, o desemantizare a elementului -omfal este prezentă în rețelele de socializare: „Noul catalog Omfal Educational în format electronic este aici!” (http://www.omfaleducational.ro/catalog/\#page/1). Acest catalog propune ,în cele 335 de pagini peste 4300 de produse concepute și selectate atent pentru educația copiilor: jocuri senzoriale, materiale didactice, jocuri educative și resurse pedagogice, articole pentru activităţi artistice și creative, jocuri de rol, educație fizică, amenajare, echipare și decorarea claselor, precum și materiale pentru birou, rechizite si birotica”, care, presupunem, ar trebui să asigure o educație „,centrată”, „omfalică”, distinctă de cea tradițională. 
Astfel, apar denumiri de tipul: jucării omfal/ omfal jucării, grădiniță omfal, mobilier omfal, omfal scaun etc.; distribuitor fiind OMFAL EDUCATIONAL SRL (www.omfal.ro).

Prin urmare, cuvântul grec omphalos, lexem autonom, atestat în Dicționarul actualizat de neologisme, devine (sub influența regularității, productivității și a variabilității semantice) afixoid (omfal(o)-; -omfal), parte componentă a cuvântului, ca mai apoi să fie supus procesului de relexicalizare (omfal, cuvânt desemantizat).

Evoluțiile semantice ale componentei grecești a dubletului savant sunt următoarele:

- omphalos ,piatră sacră” $\rightarrow$ centru $\rightarrow$ umbilicus $\rightarrow$ buric (corpul uman)/ ombilic $\rightarrow$ sac vitelin;

- omphalos ,piatră sacră” $\rightarrow$ omfal $\rightarrow$ centru;

- omphalos ,piatră sacră” $\rightarrow$ omfal $\rightarrow$ umflăturăa;

- omphalos ,piatră sacră” $\rightarrow$ corelare semantică cu latinescul umbo, onis, $m$ „piatră de hotar”.

\section{Concluzii}

Terminologia medicală în limba română prezintă o simbioză a terminologiei medicale naţionale (formată în baza cuvintelor preluate din lexicul tradiţional autohton, supuse procesului de terminologizare) şi a celei internaţionale (terminologie axată pe lexiconul general internaţional).

Componentele dubletului savant $<$ lat. umbilicus, și $<$ gr. omphalos „ombilic” sunt prezente în ambele terminologii - naţională şi internaţională. Componenta latină se înscrie în terminologia naţională; componenta greacă, de la care derivă elementul terminologic omfal(o)-; -omfal - în cea internaţională. Dubletul desemnează un segment anatomic, dar este prezent și în terminologia clinică, în denumiri de boli. În structura termenilor clinici, dubletul indică, în special, localizarea afecțiunii. Se pretează a fi combinat cu afixe, afixoide, dar se regăsește și în structura termenilor-sintagmă. Considerăm cuvântul latinesc umbo, onis, $m$ originea cuvântului umbilicus, $i, m$ de la care s-au format termenii buric și ombilic. Cuvântul grec omphalos, lexem autonom, devine sub influența regularităţii, productivității și a variabilității semantice afixoid (omfal(o)-; -omfal), parte componentă a cuvântului, ca mai apoi să fie supus procesului de relexicalizare (omfal, cuvânt desemantizat). În prezentul articol au fost arătate reperele mitologice ale acestui dublet și au fost proiectate evoluțiile semantice.

\section{Referințe bibliografice:}

ANDREI, Nicolae. Dicţionar etimologic de termeni ştiințifici. Bucureşti: Editura Ştiinţifică şi Enciclopedică, 1987.

ARNAUDOV, George. Terminologia medica polyglota en cinq langages. Latinum, русский, français, deutsch. Sofia, Bulgaria: Editio Medicina et Physcultura, 1979.

BEJENARU, Vasile, BEJENARU, Galina. Dicţionar medical rus-român. Vol. I şi II. Chişinău: Editura enciclopedică „Gh. Asachi”, 1991 
BURKE, John G. Cosmic Debris: Meteorites in History (în engleză), University of California Press, 1986.

DAUZAT, Albert. Dictionnaire étymologique de la langue française. Paris: Librairie Larousse, 1938.

DVORETSKY, Iosif. Latinsko-russkiy slovar'. Moskva: Izdatel'stvo Russkiy yazyk, 1976.

ELIADE, Mircea. Cosmologie şi alchimie babiloniană, 1937; 2nd edition, Iaşi: Editura Moldova, 1991.

GABINSCHI, Marcu Dicționarul de dublete etimologice ale limbii române. Chișinău: Litera, 1998.

I. O., 2010.

MARCU, Florin. Dicționar actualizat de neologisme. Bucureşti: Editura Saeculum

MINCU, Eugenia. Arhitectonica terminologiei medicale în limba română. Mic dicționar de elemente și dublete terminologice. Chișinău: IFR, Vătavu, 2020.

RUSU, Valeriu. Dicţionar medical, ediţia a IV-a revizuită şi adăugită. Bucureşti: Editura medicală, 2010.

SAMARIAN, Gh. Pompei. Medicina și farmacia în trecutul românesc, vol. I, 13821775, București: Tipografia Culturală, 1936.

\section{Surse:}

Omphale. https://en.wikipedia.org/wiki/Omphale

Catalog Omphal Educațional http://www.omfaleducational.ro/catalog/\#page/1

OMFAL EDUCATIONAL SRL (www.omfal.ro)

Notă: Articolul a fost realizat în cadrul proiectului de cercetare 20.80009.1606.01 Valorificarea științifică a patrimoniului lingvistic național în contextul integrării europene, Institutul de Filologie Română „B. P.-Hasdeu” al MECC. 


\title{
BALADA ,MEŞTERUL MANOLE": O INTERPRETARE ARHETIPALĂ \\ TATIANA BUTNARU
}

Doctor în filologie, conferențiar universitar

E-mail: tbotnaru66@gmail.com

ORCID: https://orcid.org/0000-0001-5771-9081

Institutul de Filologie Română „Bogdan Petriceicu-Hasdeu” (Chișinău)

\section{The Ballad „Meșterul Manole”: an Archetypal Interpretation}

\begin{abstract}
In this article, the interpretation of the ballad „Meșterul Manole" found expression in an archetypal perspective, in correlation with the message of ideas, the legendary-historical significance and the sources of mythical inspiration. A symbol of the aspiration for the perfection of a work of art, the ballad is a masterpiece of universal inspiration, where the motive of human sacrifice in the service of a social, aesthetic, spiritual ideal becomes the essence of our millennial spirituality, is the artistic synthesis of a sacred space of values their fundamentals. One of the distinctive features of the ballad is the opening to new areas of mythical transcendence, orientation to some original images, with an ancient mythological substratum, prone to successive changes, to reveal new dimensions in the aesthetic perception of the world, in the context of serious meditations on life. and death, fulfillment, and sacrifice, about the perpetuation of the human spirit through creation.

Keywords: sacred space of values, historical synchronization, elegiac chords, ballad versions, general-human values, myth of the creator, mythical-ritual initiation, sacred history, metaphorical associations, the sacrifice of building.

\section{Rezumat}

În articolul de faţă şi-a găsit expresie interpretarea baladei „Meşterul Manole” dintr-o perspectivă arhetipală, în corelaţie cu mesajul de idei al semnificaţiei legendaristorice şi al surselor de inspiraţie mitică. Simbol al aspiraţiei pentru desăvârşirea unei opere de artă, balada reprezintă o capodoperă de inspiraţie universală, unde motivul sacrificiului uman, pus în slujba unui ideal social, estetic, spiritual, devine esenţa spiritualităţii noastre milenare, este sinteza artistică a unui spaţiu sacru de valori circumscrise în aspectele lor fundamentale. Una dintre trăsăturile distinctive ale baladei constă în deschiderea către noi zone de transcendenţă mitică, în orientarea către nişte imagini originare, cu un substrat mitologic străvechi, predispus modificărilor succesive, pentru a dezvălui noi dimensiuni în percepţia estetică a lumii, în contextul
\end{abstract}




\section{LXIII

unor meditaţii grave despre viaţă şi moarte, împlinire şi sacrificiu, despre dăinuirea spiritului uman prin creaţie.

Cuvinte-cheie: spaţiu sacru de valori, sincronizare istorică, acorduri elegiace, versiuni baladeşti, valori general-umane, mitul creatorului, iniţiere mitico-ritualică, istorie sacră, asociaţii metaforice, jertfa zidirii.

Balada „Meșterul Manole”, una din cele mai reprezentative scrieri din patrimoniul nostru folcloric, dezvăluie destinul creatorului de frumos, ,reprezintă o sinteză şi un simbol al unui destin artistic, o proiecţie într-un spaţiu spiritual mitic, a unei existenţe care s-a identificat cu frumosul şi s-a devotat creaţiei" (Ciompec, 1979, p. 115). Necesitatea studierii acestei balade rezultă dintr-o serie de principii metodologice, cu anumite determinări istorico-sociale, în rezultatul interferenţei diferitor straturi culturale. Drama omului de creaţie predispus unui consum interior pentru desăvârşirea unei opere de artă, ideea despre jertfa zidirii şi aspiraţia spre absolut determină, în linii mari, substraturile arhaice concretizate în mesajul baladei. Originea acestui subiect îşi poate găsi expresie în dependenţă de anumite principii estetice, avem în vedere un rit fundamental de întemeiere condensat într-o istorie sacră despre mănăstirea Argeşului, aşa cum a fost atestat ulterior în documentele de epocă, fiind vorba de ,vechiul substrat de tradiţii şi legende al jertfei zidirii... comun întregii umanităţi” (Vrabie, 1966, p. 70). În mai multe variante înregistrate pe teren, vedem o tendinţă de contaminare şi adaptare a materialului de circulaţie folclorică unor criterii artistice noi. În majoritatea cazurilor, este respectată convenţia clasică, iar naraţiunea epică este plasată între ficţiunea mitică şi sincronizarea istorică, evoluând sub semnul unei regăsiri spirituale. „Localizarea la Curtea de Argeș a temei despre zidirea femeii, cu marea ei putere de a impresiona, accentuează I. Taloş, a avut consecinţe numeroase asupra poeziei înseşi, înainte de toate, ea a atras bogata floră de legende care circulau anterior în legătură cu mănăstirea..." (Taloş, 1973, p. 264), generând nişte situaţii inedite în asimilarea surselor miticolegendare. În consecinţă, după cum afirmă în continuare exegetul, ,cu ocazia noii localizări” nu numai că se poate depăşi „un caracter oarecum etnografic”, dar are loc conceptualizarea valorilor, este , un exemplu desăvârşit de întinerire a temelor folclorice" (ibidem, p. 264).

Acţiunea baladei se desfăşoară în dependenţă de circulaţia variantelor:

„Pe Argeş în jos,

Pe un mal frumos" (AF AŞM, 1966, f. 10).

sau

unde

„Pe un plan frumos” (AF AŞM, 1968, f.86).

„Plimbă, mi se plimbă,

Domnul Negru Vodă,

$\mathrm{Cu}$ opt telegari,

Nouă meşteri mari,

$\mathrm{Cu}$ Manole zece,

Care mi-i întrece" (AF AŞM, 1968, f. 86-90). 
În opinia specialiştilor (Munteanu, 1982, p. 308), Negru Vodă figurează în baladă în locul lui Neagoe Basarab, din porunca căruia a fost construită mănăstirea de la Curtea de Argeş. Dorind să ridice o biserică „cum n-a fost alta”, în unele versiuni, însuşi domnitorul participă la alegerea unui „loc de mănăstire” şi porneşte în căutarea unui ,zid vechi şi mucezit, demult părăsit” (AF AŞM, 1968, f. 86-90). Într-un text depistat în sudul Basarabiei (astăzi în regiunea Odessa), aflându-se în căutarea zidului, Manole cu meşterii îl întâlnesc pe „Noiam purcăraş”, care-i duce la locul râvnit:

„Mult că n-a umblat,

Peste zid a dat” (AF AŞM, 1968, f. 86-90).

Motivul surpării zidurilor se împleteşte cu necesitatea de a fi sacrificată o fiinţă omenească şi „zidirii” acesteia în temelii. Manole are revelaţia unui vis, care va salva, în cele din urmă situaţia şi decide:

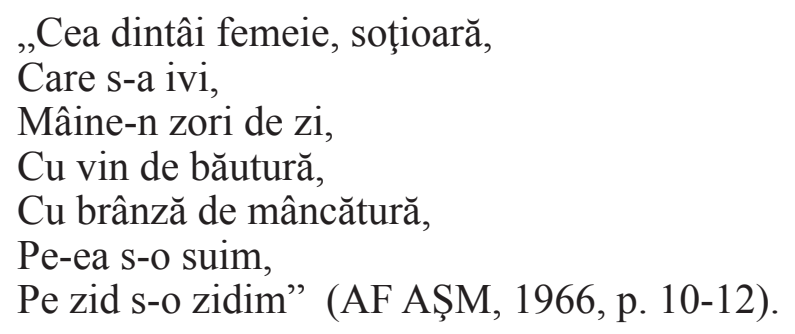

Cronologizarea motivului pare să fie determinată de nişte colizii interioare, care aprofundează sursele de inspiraţie mitică. Ceea ce Negru Vodă porunceşte „,ca domn", se converteşte prin sacrificiul lui Manole într-o valoare estetică superioară, devine un „teribil memento pentru toţi slujitorii artei” (Caraman, 2000, p. 201). $\mathrm{Cu}$ alte cuvinte, se poate intui drama artistului, care, fiind pus faţă-n faţă cu tirania unui despot, îşi găseşte o singură alternativă, de imortalizare prin opera de artă. „Zbuciumul lui Manole”, în tendinţa de a zămisli frumosul, ,este zbuciumul oricărui mare creator de valori umane" (Vrabie, 1966, p. 86). Păstrând prin convenţie deschiderea spre mitologie, balada transpare printr-o declanşare de lumini şi umbre, indică necesitatea unei jertfe pentru temeinicia zidurilor. Din aceste considerente, Meşterul Manole capătă semnificaţia generalizată a creatorului de frumos, conştient de gravitatea situaţiei în care se află. Potrivit precizării lui E. Munteanu, el reprezintă ,pe fiecare creator de artă şi de acţiune, fiecare zămislitor şi întemeietor care să îngroape în efortul lui tot ce are mai scump : nu se poate viaţă nouă fără jertfă" (Munteanu, 1982, p. 224). Jertfa Meşterului Manole implică ascensiunea omului la o dimensiune simbolică, datorită căreia se manifestă rosturile sale existenţiale circumscrise în lumina iniţierii dacice.

Modificările parvenite în rezultatul fenomenului de contaminare a diferitor elemente şi clişee artistice transferă drama creatorului într-un context estetic aparte, unde vedem existenţa simultană a mai multor motive, iar imaginile artistice reproduse transpar în relaţie de complementaritate cu unele toposuri de provenienţă mitică, 


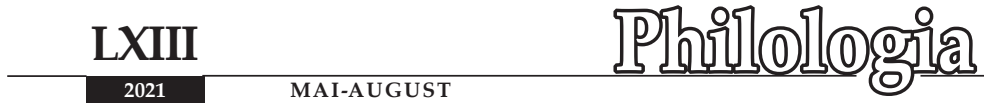

desprinse fie prin filiera unor legende străvechi, fie din experienţa generalizată a existenţei umane. Depăşind sfera familiară, observăm prezenţa unor situaţii poetice, care vor transpare sub cele mai diferite forme şi la diferite niveluri de receptare mitică. Pentru a revărsa o lumină mai discretă asupra condiţiei artistului, autorul popular a fixat în sistemul său estetic şi metafora „femeie - biserică”, care ar putea fi interpretată dintr-o perspectivă multiplă. Aproape înrudite, aceste motive caută să pătrundă în dezlegarea unor taine ascunse ale spiritului omenesc. $\mathrm{Cu}$ această ocazie, S. Ispas vorbește despre „,biserica biruitoare” întruchipată „,printr-o sintagmă familiară creştinismului ortodox" (Ispas, 2002, p. 262). Desăvârşirea unei opere semnifică ideea „de sacru, de sublim şi de frumos” - categorii estetice, care, totodată, mai sunt orientate şi spre ideea generalizată de neam. Exegeta are în vedere, în acelaşi timp, cultul strămoşilor, „recunoaşterea lor, comemorarea şi actualizarea actelor sacrificiale, reprezentaţi prin biserica construită de meşterularhitect Manole" (ibidem). Dacă biserica include ideea unei valori sacre, atunci femeia atinge aceeaşi dimensiune prin destinul ei, de a perpetua existența omenească. Păstrând prin convenţie deschiderea spre mitologie, în balada „Meşterul Manole”, prezenţa femeii e determinată de un impuls lăuntric, cu semnificaţie dublă - ea este născătoarea vieţii şi imboldul spre creaţie. De aceea, mitul creatorului este, în acelaşi timp, şi cântecul de lebădă al femeii, care acceptă sacrificiul pentru împlinirea menirii sale supreme, de dăruire şi desăvârşire spirituală. Din interiorul sufletesc al lui Manole, drama creaţiei este transferată în universul Anei, pentru care necesitatea jertfirii de sine devine o condiţie indispensabilă. „În fond, problema nici nu este a unei alegeri prin creaţie şi iubire, subliniază L. Rusu, ci a unui singur drum: creaţie prin iubire” (Rusu, 1981, p. 208). Odată ce „,...) creaţia mare nu poate să se nască decât din tot ce este mai profund, mai nobil, mai generos în fiinţa umană" (ibidem, p. 303), ea consfinţeşte rosturile existenţiale, le orientează spre culmile transcendenţei universale.

În versiunile atestate pe teren din diferite aşezări din Basarabia, se accentuează, în mod special, episodul săvârşirii ritului de sacrificare şi suferinţele femeii jertfite. Dacă la început zidirea femeii pare mai mult o glumă şi redă undeva în subtext nuanţa unui joc dintre îndrăgostiţi, pe parcurs ea capătă o accepţie dramatică. Trecerea de la gluma aparentă la o profundă dramă omenească este redată prin lamentaţiile copleşitoare ale eroinei:

„Manole, Manole, meştere Manole, Ajungă-ţi de şagă,

Că nu-i bună treabă..." (AF AŞM, 1963, f. 117-118),

ca mai apoi să-şi exteriorizeze direct suferinţele:

„Viaţa mi se stinge,

Trupuşoru-mi strânge,

Viaţa mi se stinge" (AF AŞM, 1966, f. 10-12).

Motivul jertfei creatoare se suprapune unor diverse resorturi artistice, care ar putea fi interpretate în dependenţă de semnificaţia imaginilor artistice 
desprinse din mesajul baladei. Femeia predispusă să fie „zidită” capătă, în cele din urmă, o semnificaţie arhetipală aparte şi indică o culminaţie a suferinţei în necuprinderea cosmică, acolo unde şi-a găsit expresie „marea poezie a durerii” (Rusu, 1967, p. 151). Rezonanţele tragice, conjugate cu resemnarea, sunt înlocuite treptat prin nişte implicaţii danaidice cu deschidere spre ancestral. Devenită fântână, eroina îşi asigură continuitatea existenţei sale terestre şi, ca „o cruce", se înalţă la piatra de hotar a amintirii, ca să vorbească oamenilor despre cutezătoarea faptă a meşterului Manole. Situaţiile tragice sunt aplanate în plan vizionar. La chemarea destinului, personajul feminin se înalţă la dimensiunile miticului prin voinţa de sacrificiu:

\author{
„Iar unde-mi cădea \\ Cruce se făcea, \\ Şi de-alăturea, \\ Cișmea izvora \\ $\mathrm{Cu}$ apă curată. \\ Trecută prin piatră, \\ $\mathrm{Cu}$ lacrimi sărate \\ De Caplea vărsate" (Teodorescu, 1982, p. 216).
}

În esenţialitatea sa simbolică, fântâna capătă nişte semnificaţii artisticemultiple, ea exprimă chezăşia unor resorturi sufleteşti de adâncime mitică, de unde vor izvorî nişte acorduri lirice copleşitoare, redimensionează din interior toate impulsurile și trăirile actului de creaţie. E „dimensiunea scump plătită frumosului”, care dăinuie în conştiinţa omului de artă cu claritatea şi simplitatea adevărurilor primordiale ale vieţii, unde are loc „totală şi grea dăruire”. Figuraţia mitică se manifestă într-o sinteză de ritual şi se înscrie ca un reflex ,,al nemuririi dacice” (Munteanu, 1982, p. 172). „Pietrificată” în mrejele tăcerii, în taină şi mister, metafora fântânii mai capătă undeva în subtext şi o semnificaţie de recviem, devine o simbolică întruchipare a suferinţei şi jertfei, determinată fiind de o seninătate dureroasă, dar în același timp, ne mai predispune spre o retrospecţie sentimentală, de continuă aducere-aminte despre sacrificiul eroilor. Geniul popular adaptează situaţia tradiţional-folclorică unor dimensiuni estetice noi, găsind o echivalenţă poetică corespunzătoare între orizonturile mitice şi viziunea personală de convertire a materialului folcloric. În această ordine de idei, sunt explorate înţelesurile filosofice ale miticului şi, ca în intuiţia lui Brâncuşi, fântâna ne adună la ,masă tăcerii divine”, unde alături de efigia meşterului de la Argeş, se va profila şi chipul femeii „zidite”, care, prin decizia ei cutremurătoare de imortalizare prin creație, înclină spre tărâmurile transcendenței cosmice, acolo unde Marele Anonim îşi determină calea spre eternitate.

Versurile ce urmează în continuare:

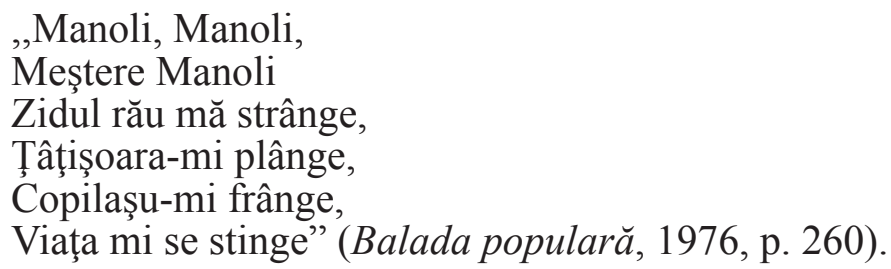




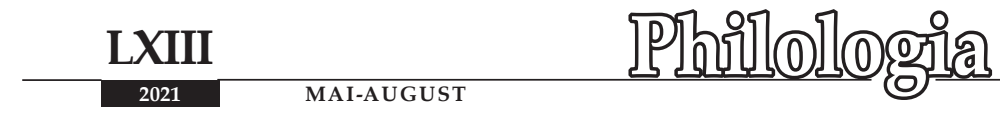

devin o expresie a unei descătuşări simbolice, a unei evaziuni sufleteşti în sfera arhetipală a sacrului. Balada „Meşterul Manole” culminează cu sacrificiul eroilor, evocarea căruia transpare din asociaţiile metaforice de sorginte mitică. Trecând peste aspectul tragic al existenţei omeneşti, autorul anonim îi găseşte dezlegare prin nişte valenţe spirituale cu caracter general-uman, prin cugetări grave despre viaţă și moarte, despre împlinire și sacrificiu, despre dăinuirea spiritului uman prin creaţie. Eroii îşi vor menţine existenţa într-un context erotico-familial, ei se vor identifica, în cele din urmă, cu o „mănăstire de iubire”, ca să aprofundeze „sublimarea sofianică” (Blaga, 1969, p. 303) a resorturilor existenţiale majore. Natura, cosmosul terestru, întreg universul participă la drama sufletească a lui Manole şi a femeii care a acceptat sacrificiul pentru desăvârşirea lor spirituală. Intensitatea elegiacă a versurilor din mai multe texte baladeşti se intensifică, în special, prin viziunea miticosimbolică a copilului orfan, rămas fără îngrijirea părintească, dar amplasat într-o zonă a resorturilor mitice, acolo unde predomină o stare de germinaţie totalizatoare, iar bunele ursitoare vor poposi ca într-o „lume de basm populate de zeităţi şi stihii binefăcătoare”, având menirea să dezvăluie „o augustă împăcare a omului cu firea veşnic armonioasă şi a aduce o mişcare mai calmă în ritmul agitat al naraţiunii" (Ciompec, 1979, p. 45). În mai multe versiuni ale baladei „Meşterul Manole”, persistă o natură umanizată, ea participă la viaţa sufletească a eroilor epici, iar copilul lăsat în cadrul ritmurilor primordiale din ambianţa naturală, capătă o nuanţă sacrală şi va prelua o funcţie mitică aparte, el se va integra în anturajul selenar al cosmosului prin nişte calităţi neobişnuite, exprimând ideea de continuitate a vieţii. Prin imaginea copilului mitic, vor fi dezvăluite noi dimensiuni ontologice, geniul anonim relevă noi niveluri de aprofundare a trăirilor umane, care se vor încadra în tendinţa de exteriorizare a unui ,sentiment total, abisal, ireversibil, în stare de cele mai sublime momente de elevaţie”, dar şi „de catastrofele cele mai dureroase" (Fochi, 1988, p. 15). Versurile dintr-un text baladesc înregistrat de A. Teodorescu:

„Copilaşul tău,
Pruncuşorul meu,
Vază-1 Dumnezeu.
Tu cum 1-ai lăsat
În pat
Desfăşat,
Zânele c-or trece,
La el s-or întrece,
Ţaţă că i-or da;

Ninsoarea d-o ninge, Pe el mi l-or unge; Ploi când o ploua; Pe el 1-or scălda; Vânt când o sufla, Mi 1-o legăna, Dulce legănare, Pân 's-o face mare" (Teodorescu, 1982, p. 526).

relevă o situaţie iniţiatică, raportată ,unei stări primare geomorfe a vieţii pe pământ reprezentată prin asocierea vegetalului" (Rusu, 2005, p. 55). În alte variante, pruncul este ocrotit de Dumnezeu, de codru, de păsările cerului, vegetaţie, elemente care indică perpetuarea unor modele mitice străvechi, este ,un material, probabil foarte 
vechi" (Fochi, 1980, p. 311), aşa cum ne atenţionează A. Fochi, şi are legătură cu moartea iniţiatică din sânul naturii din balada „Mioriţa” (ibidem). Imaginea fântânii, dar şi cea a copilului lăsat în seama stihiilor din mediul natural, ,,sub directa îngrijire plină de solitudine a naturii” (ibidem), poartă o semnificaţie mitico-legendară şi redă integrarea personajelor baladești într-un spaţiu sacralizat, condensat până la saturaţie de nişte trăiri sufletești de excepţie, este dezvăluită o cosmogonie specifică, cu deschidere spre o zonă a misterelor şi a resorturilor primare.

Balada „Meşterul Manole” anunţă un deznodământ situat între nişte dimensiuni valorice de alternativă, acolo unde viaţa şi moartea, amurgul şi lumina, dragostea şi suferinţa se condiţionează reciproc. La fel ca şi „Mioriţa”, această lucrare e străluminată de o senzaţie de resemnare, de revigorare a substratului mitic. Calea ciobanului mioritic circumscrie conturul unui spaţiu mitic marcat de ideea dacică a nemuririi şi ascensiunea permanentă a omului spre valoarea supremă a condiţiei sale - creaţia. Sensurile de luciditate mioritică conjugate cu rosturile personalităţii creatoare se bazează pe cadrul vizionar al unor corespondenţe estetice de sorginte mitică. Transformarea meşterului în fântână include în sine o metaforă evocatoare despre frumuseţea faptei dăruite, despre condiţia supremă a existenţei omeneşti desăvârşită prin dragoste şi creaţie. Imaginea fântânii şi curgerea ei ireversibilă cu:

„Apă curătoare

Cu nouă izvoare,

Cu apă uşoară” (Teodorescu, 1982, p. 215).

copleşeşte prin profunzime şi armonie, versul curge lent ca un murmur de izvor, cu unduiri melancolice, ca un plâns cosmic al universului, printre „sfere şi scânteie”, prin „hăuri de lumini stelare”, acolo unde are loc actul sacramental „de totală şi grea dăruire". În cele din urmă, fântâna capătă asociaţia de comoară a spiritualităţii noastre milenare, devine lacrimă durută condensată în eternitatea fiinţării omului, a rosturilor sale plenipotenţiare. Autorul anonim adaptează situaţia tradiţionalfolclorică unor dimensiuni valorice sufleteşti şi creează cupola morală a versului său, ca să înveşnicească sacrificiul eroilor în turle de catedrală, să-i aducă la o condiţie indispensabilă a ființării lor omeneşti, materializată ,prin funcţia experimentării sacrului” (Ispas, 2010, p. 14). Or, fântâna „cu apă curătoare” se află între „epifanie şi sacrament" (ibidem), ea semnifică dobândirea perenităţii prin vocaţie şi cutezanţă creatoare, prin disponibilitatea ,spre veşnica rotire a meditaţiei în sfera «stării poeziei»" (Ciompec, 1979, p. 215). Asemenea tinerilor îndrăgostiţi, care în cele din urmă se vor identifica cu ,arborii îmbrăţişaţi”, eroii epici din balada „Meşterul Manole" vor dăinui uniţi prin moarte, ca o simbolică întruchipare a suferinţei şi jertfei, a perenităţii sacrificiului, ,în semn de înălţare a lăcaşului sfânt”.

În concluzie vom releva că balada „Meşterul Manole” dezvoltă „un adevărat cod axiologic al etnosului folcloric" (Cârstean, 1984, p. 201), iar în planul funcţionalităţii mitice ea rămâne o problemă complexă pentru sfera de cercetare. Aşa cum am încercat să demonstrăm, problema merită să fie abordată în lumina unor interpretări multiple, întrucât subiectul respectiv se manifestă în eposul nuvelistic prin nişte calităţi de naraţie deosebite, prin ideea de promovare 
şi menţinere a valorilor general-umane într-un spaţiu spiritual mitic, constituie „punctul de plecare al oricărei evaziuni serioase în sfera poeticului” (Fochi, 1975, p. 48), în corelaţie cu modificările succesive din cadrul unui material factologic străvechi aflat în circulaţie.

\section{Referinţe bibliografice:}

AF AŞM, 1963, ms. 147, f. 117-118, Pleşeni-Leova, inf. E. Mocanu,culeg. N .Băieşu. AF AŞM, 1966, ms.164, f. 10-12, Moleşti-Hânceşti, inf. P. Leunte, culeg .E. Junghietu. AF AŞM, 1968, ms. 178, f. 86-90, Plavni (Barta) Reni-Odessa, inf. Gh. Bulgaru, culeg. Gr. Botezatu.

ANGHELESCU, Silviu. Mitul şi literatura. Bucureşti: Editura Univers, 1999.

Balada populară. (Alcătuirea, introductiv şi comentariile de A. Hâncu) Chişinău: Editura Ştiinţa, 1976.

BLAGA, Lucian. Trilogia Culturii. Bucureşti: EPLU, 1969.

CARAMAN, Petru. Pământ şi apă. Contribuţie etnologică la studiul simbolicei eminesciene. Bucureşti:Editura Elion, 2000.

CIOMPEC, Gheorghe. Motivul creaţiei în literatura română. București: Editura Minerva, 1979.

CÂRSTEAN, Stelian. Balada şi folclorul Moldovei de Nord. Bucureşti: Editura Minerva, 1984.

FOCHI, Adrian. Mioriţa. Tipologie, circulație, geneză, texte. Bucureşti: Editura Academiei, 1975.

FOCHI, Adrian. Estetica oralităţii. București: Editura Minerva, 1980. 1988.

FOCHI, Adrian. Valori ale culturii populare române. Bucureşti: Editura Minerva,

ISPAS, Sabina. Embleme şi stereotipii. Pledoarie pentru o abordare diversificată a culturilor orale. În: Identitatea limbii şi culturii române din perspectiva globalizării: Volum îngrijit de Ofelia Ichim şi Florin Teodor Olariu. Iaşi: 2002.

ISPAS, Sabina. Colindatul în cadrul culturii tradiţionale româneşti. În: Tabor, nr. 9, decembrie, 2010.

MUNTEANU, Elizabeta, Motive mitice în dramaturgia românească. Bucureşti: Editura Minerva, 1982.

RUSU, Aurelia. 15 iunie. M. Eminescu. În: Buletin. Serie nouă, 2005, nr. 2.

RUSU, Liviu. De la Eminescu la Blaga. Bucureşti: Editura Cartea românească, 1981.

RUSU, Liviu. Viziunea lumii în poezia noastră populară. Bucureşti: Editura pentru Literatură, 1967. 1982.

TEODORESCU, Alexandru. Poezii populare româneşti. Bucureşti: Editura Minerva,

TALOŞ, Ioan. Meşterul Manole. Contribuţii la studiul unei teme de folclor european. Bucureşti: Editura Minerva, 1973.

VRABIE, Gheorghe. Balada populară română. Bucureşti: Editura Academiei, 1966.

Notă: Articolul a fost realizat în cadrul proiectului de cercetare 20.80009.1606.03 Contexte socioculturale autohtone şi interconexiuni europene în creaţia populară şi literatura cultă din Basarabia (sec. XIX până în prezent), Institutul de Filologie Română „B. P.-Hasdeu” al MECC. 


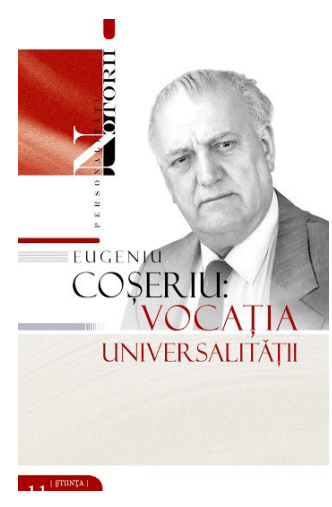

\section{Eugeniu Coșeriu: vocația universalității.}

Chișinău: Știința, 2021, 484 p.

În 27 iulie 2021 Eugeniu Coșeriu (născut în 1921, comuna Mihăileni, județul Bălți), celebritate lingvistică de talie mondială, ar fi împlinit 100 de ani de la naștere. Acestei date comemorative i-au fost consacrate diverse manifestări științifice, desfășurate ${ }^{2}$ sau care urmează să aibă $\operatorname{loc}^{3}$, editări de reviste ${ }^{4}$ și de carte. La una dintre cărțile tipărite cu acest prilej ne vom referi în cele ce urmează.

E vorba de volumul Eugeniu Coşeriu: vocaţia universalităţii, rezultat al conlucrării Facultății de Litere a Universității de Stat „Alecu Russo” din Bălți, reprezentată de prof. univ., dr. hab. Gheorghe Popa, și cunoscuta editură chișinăuiană Știința (director, dr. ing. Gheorghe Prini), colaborarea având un scop bine determinat: pregătirea și punerea în circulație științifică a unei lucrări dedicate centenarului lui Eugeniu Coșeriu. Prezentăm în continuare structura volumului.

${ }^{1}$ Ideile principale ale acestei prezentări de carte au fost expuse de autorul acestor rânduri, într-o variantă prescurtată, în cadrul lansării lucrării, în data de 27 iulie, la Biblioteca Municipală „B. P. Hasdeu” din Chișinău, asistată de o expoziție impresionantă de fotografii și texte comentate din creația lui Eugeniu Coșeriu. Pe marginea cărții au luat cuvântul: Mihai Cimpoi, Maria Şleahtițchi și autorul ediției, Gheorghe Popa. Moderatorul prezentării a fost Mircea Ciobanu, responsabil de ediție.

${ }_{2}^{2}$ Avem în vedere Congresul Internațional Coșeriu [Coseriana VIII], cu titlul „Coseriu’s Linguistics. Originand Actuality” [Lingvistica lui Coșeriu. Origine și Actualitate], care și-a ținut lucrările la Universitatea din Zürich (Elveția) în perioada 16-18 iunie 2021. În cadrul evenimentului a fost prezentată, de Cristina Bleorțu, ediția îngrijită de Gh. Popa (vezi Floarea Vîrban, Congresul Internațional Coșeriu la a VIII-a ediție. În: „Limba Română” (Chișinău), 2021, nr. 4 (264), p. 118-126). Precizăm, de asemenea, că o altă prezentare a volumului, de data aceasta la Bălți, a avut loc în data de 22 iunie, la Universitatea de Stat „Alecu Russo”.

${ }^{3}$ Institutul de Filologie Română „Bogdan Petriceicu-Hasdeu”, în colaborare cu Universitatea de Stat „Alecu Russo” din Bălţi și Institutul de Filologie Română „A. Philippide” al Academiei Române, organizează, în data de 6-7 octombrie 2021, Conferința științifică internațională „Filologia modernă: realizări și perspective în context european”. Ediția a XV-a, cu genericul Limbajul ca sumă de valori, este dedicată aniversării a 100 de ani de la nașterea lui Eugeniu Coșeriu.

${ }^{4}$ Revista „Limba Română” (Chișinău), nr. 4 (264), iulie-august 2021 i-a consacrat Magistrului o ediție specială: Eugeniu Coșeriu - 100. 


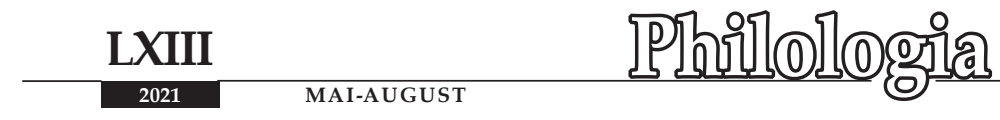

Deschide lucrarea capitolul intitulat Eugeniu Coșeriu: drumurile vieții și ale afirmării (p. 5-21), în care, așa cum se poate deduce ușor, sunt evocate momentele biografice și calea parcursă în devenire ale lui Eugeniu Coșeriu, autorul ediției, Gheorghe Popa, folosind inspirat, în calitate de moto, chiar comentariile marelui lingvist. Iată, bunăoară, câteva dintre acestea: „[...] pentru că e baștina mea, Mihăileni e cea mai frumoasă localitate din Basarabia” (p. 9), ,[...] am făcut un liceu extraordinar la Bălți [...]” (p. 10), „Eu am umblat pe la multe universități, invățând ce se putea sau predând ce puteam, dar totuși Universitatea din Iași, prima mea universitate, deși am studiat aici numai un an, a rămas într-un fel tot timpul universitatea mea” (p. 13), „Italia a însemnat pentru mine foarte mult. [...] În primul rând, a schimbat perspectiva mea românească într-o perspectivă universală, nu numai datorită universalității și tradiției culturii italiene, ci și datorită faptului că, trecând de la o perspectivă la alta, mi-am dat seama de multitudinea perspectivelor posibile" (p. 14).

Urmează Tabel cronologic (p. 22-25), care, în afară de anii biografici, contine denumirea lucrărilor lui Eugeniu Coșeriu publicate la diferite edituri, distincțiile de stat obținute, precum și titlul onorific de doctor honoris causa de care s-a învrednicit marele lingvist din partea a 40 de instituții academice din lume.

Încheie capitolul introductiv al cărții Notă asupra ediției (p. 26-27), în care, printre altele, se precizează că volumul, „vine nu numai să completeze colecția de carte Personalități notorii a prestigioasei Edituri Știința, dar și să reanimeze mai vechile colaborări ale editurii nominalizate cu Eugeniu Coșeriu, publicându-i întâia carte în limba română (,Lingvistica din perspectiva spațială și antropologică”, 1994), coorganizând și cofinanțând, totodată, Colocviul „Filologia secolului al XXI-lea", ediția I (2001). La aceeași editură apăreau, de asemenea, volumul materialelor Colocviului în discuție, intitulat „Un lingvist pentru secolul XXI” (2002), precum și volumul de interviuri „Universul din scoică” (2004)” (p. 26). Cele aproape 500 de pagini s-au dovedit nici pe departe încăpătoare pentru includerea în volum a atâtor și atâtor materiale despre viața și opera lui Eugeniu Coșeriu. În acest sens, autorul scrie: „Luând în considerare că volumul lucrării este limitat, am fost puși în situația, pe de o parte, de a renunța neonorabil la multele, dar consistentele materiale (se estimează cca 4500) despre viața și opera redutabilului savant și, concomitent, de a recurge - cu strângere de inimă - la prescurtări masive. Toate aceste „reduceri” au fost făcute (sperăm) fără a prejudicia conținutul textului, utilizând puncte de suspensie între paranteze drepte" (p. 27). În fine, Gh. Popa stabilește criteriile de care s-a condus în alcătuirea ediției: „La selectarea și gruparea materialelor s-a ținut cont de obiectivul major al lucrării: de a cuprinde și de a dezvălui, pe cât mai mult posibil, dimensiunile personalității lui E. Coșeriu din diverse perspective: biografică, spirituală, intelectuală, științifică, profesională etc. În plus, am luat în calcul și ideea că potențiali beneficiari ai volumului pot să fie nu numai filologii, dar și specialiști din alte domenii (știința literaturii, filozofie, estetică, logică și, de ce nu, științele naturii etc.)” (p. 27).

Ceea ce formează partea semnificativă a volumului sunt articolele și studiile consacrate operei lingvistice și preocupărilor literare ale lui Eugeniu Coșeriu, publicate mai demult în diverse reviste și volume (astăzi mai greu de găsit sau cu un tiraj epuizat), iar acum reunite în prima secțiune intitulată Repere și rezonanțe 
coșeriene (p. 30-136). Iată, în formă rezumativă, unele din ideile, convingerile și constatările autorilor lingviști ai celor 10 expuneri scrise, selectate de autorul ediției.

Astfel, Iorgu Iordan, primul profesor de limba română al lui Eugeniu Coșeriu de la universitatea ieșeană, e de părerea, în Eugenio Coseriu, teoretician al limbajului și istoric al lingvisticii (tradus din franceză de Cristina Varga), că „,cercetările sale arată foarte clar, chiar și unui lector mai puțin avizat, că ceea ce îl interesează nu sunt faptele pe care le invocă, nici relațiile dintre ele considerate din punctul de vedere al lingvisticii romanice, istorice sau descriptive, ci semnificatia lor teoretică, posibilitatea lor teoretică de a le integra într-o viziune de ansamblu, care să-i permită să-și dea seama de caracteristicile generale ale limbajului uman și de esența acestuia, făcând abstracție de forma concretă, reală, pe care o are în timp și în spațiu” (p. 30).

Dumitru Copceag, în „Realismul lingvistic” sau doctrina științifică a lui Eugenio Coseriu (tradus din spaniolă de Eugenia Bojoga), crede că „,există în opera Maestrului, alături de valoroasa analiză rațională a realității limbajului, mărturii ale unei intuiții artistice pe potrivă” (p. 41).

Dumitru Irimia, în Un mare lingvist contemporan: Eugen Coșeriu, analizează studiile lui Eugeniu Coșeriu publicate în perioada când era profesor de lingvistică generală și indo-europeană și director al Institutului de Lingvistică de la Universitatea din Montevideo (Uruguay), trăgând următoarea concluzie: „el s-a manifestat cu preponderență în lingvistica teoretică, impunându-se ca unul din cei mai mari lingviști contemporani” (p. 46).

Stelian Dumistrăcel, în Întrebările și promisiunile începutului, examinează îndeaproape primele cercetări lingvistice ale lui Eugeniu Coșeriu, intitulate Limbă și folclor din Basarabia și Material lingvistic basarabean.

Mircea Borcilă, în Eugeniu Coșeriu: fondator al lingvisticii ca știință a culturii, se referă la rațiunile principale fundamentate de Maestru în Lecții de lingvistică generală din 1981 .

Cornel Vîlcu, în Sensul polemic al integralismului, este convins că ,integralismul lingvistic reclamă (...) o modificare nu a procedurilor marginale, ci a punctului de întemeiere; și, câtă vreme nu se săvârșește această modificare, opera coșeriană rămâne (...) de neînțeles $(. .$.$) (p. 70).$

Dina Vîlcu, în Integralism vs. generativism (schiță a unei confruntări), ia în discuție cele două direcții de cercetare lingvistică: integralismul și generativismul. Conform convingerii lui Eugeniu Coșeriu, ,integralismul se asociază științelor culturale, iar generativismul celor naturale" (p. 75).

Nicolae Saramandu, în Eugeniu Coșeriu: teoretician al limbajului, constată că Maestrul ,,a fundamentat o teorie despre limbă și limbaj ca obiect al culturii, delimitând lingvistica în cadrul științelor despre om, după o perioadă de schematism și formalism exagerat, care a marcat lingvistica secolului XX, de la structuralismul saussurian la ,generativismul” chomskyan” (p. 85).

Alexandru Bantoș, în Un lingvist care vine din viitor: Eugeniu Coșeriu și realitățile lingvistice din Republica Moldova, este ferm convins că „lucrările lui Eugeniu Coșeriu, în special cele ce abordează (...) identitatea limbii și a poporului nostru, trebuie să fie așezate la temelia politicii lingvistice și naționale din Republica Moldova" (p. 91). 


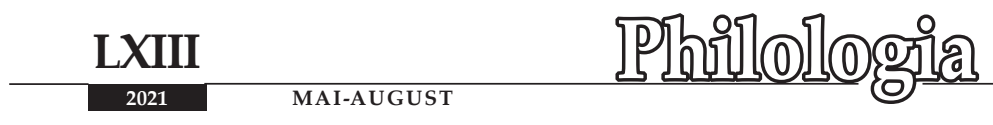

Stelian Dumistrăcel și Doina Hreapcă, în Eugeniu Coșeriu: o perspectivă romanică în studierea frazeologiei românești, referindu-se la clasificarea frazeologismelor studiate de Profesor, subliniază că ,avantajul lui Coșeriu, pentru analiza și explicarea (...) originii unor frazeologisme (...), este raportarea la limba lui maternă, româna, necunoscută (sau destul de puțin cunoscută) romaniștilor din Italia, Franța ori Spania, pe de o parte, iar pe de altă parte, buna cunoaștere a limbilor italiană și spaniolă, dar și a francezei (...)” (p. 93).

Despre preocupările lui Eugeniu Coșeriu pentru estetică și critică literară aflăm din consemnarea lui Nicolae Saramandu: „In zilele noastre universalitatea omului de cultură este dată, mai curând, de faptul că se realizează într-un anumit domeniu, dar cu deschideri universale". Despre scrierile sale literare de pe timpul studiilor ieșene şi din perioada aflării sale în Italia și în Uruguay aflăm din interviul lui Constantin Severin, „Toate problemele culturii și toate formele ei sunt şi ale noastre", din articolele semnate de Dumitru Irimia, Literatura lui E. Coșeriu în limba italiană, și de Nicolae Leahu, Eugeniu Coșeriu: poetul și prozatorul. Tot de domeniul literaturii, de care s-a ocupat Maestrul, țin și articolele semnate de Mihai Cimpoi, Eugen Coșeriu, precursor al [literaturii] absurdului, Elena Ungureanu, Eugeniu Coșeriu despre arta limbajului și limbajul artei, Oana Boc, Lingvistica și textualitatea literară.

Urmează mai multe convorbiri cu și despre Eugeniu Coșeriu, regrupate în secțiunea a II-a, Interviuri, având două subtitluri (p. 138-386). Printre interlocutorii primului subcapitol, intitulat Dialoguri cu Eugeniu Coșeriu sau Magistrul cu sine insuși, se numără Nicolae Saramandu, Lingvistica integrală (fragment), Vasile Gârneț, „Destinul Basarabiei îl văd cu speranță și cu mare teamă ... Trăiesc intens acest destin și mă doare în mod constant", Lucian Lazăr, Ființă şi limbaj (fragment), Johannes Kabatek și Adolfo Murguía, „A spune lucrurile așa cum sunt...", Gheorghe Popa, Maria Șleahtițchi și Nicolae Leahu, Universul din scoică (fragment), Angela Furtună, „Trebuie să cunoaștem toată tradiția și să mergem mai departe de tradiția limitată pe care o poate avea cultura unei țări”’.

Dintre cosemnatarii celui de-al doilea subcapitol, intitulat Dialoguri cu Eugeniu Coșeriu sau Magistrul în oglinzile receptării, se remarcă Eugenia Bojoga, prin articolul Eugeniu Coșeriu în memoria discipolilor săi, dar, mai ales, prin mai multe convorbiri întreținute cu Benjamin García Hernández: „Eugeniu Coșeriu este un om universal, a cărui știință o împărtășim multe popoare și, prin urmare, fiecare îl consideră ca fiind «al său»”, cu Reinhard Meisterfeld: „Principiul tradiției ne obligă să transmitem mai departe învățătura lui Eugeniu Coșeriu", cu Gunter Narr: „Am înființat Editura Narr din dorința de a-i publica studiile lui Eugen Coșeriu”, cu Oscar Loureda Lamas: „Nimeni nu a propus atât de devreme, la mijlocul anilor '60, nici cu atâta coerență și claritate, o știință a textului, așa cum a făcut-o Eugen Coșeriu”, cu Adolfo Murguía: „Eugeniu Coșeriu a devenit din întâmplare lingvist, la fel de bine putea să devină și filosof...”, cu Vincenzo Orioles: „Eugen Coșeriu a avut o viziune europeană asupra lingvisticii”. Mai consemnăm dialogul lui Vitalie Ciobanu cu Mircea Borcilă: „Opera lui Coșeriu a învins deja veacurile”, precum și cel al lui Cristinel Munteanu cu Rudolf Windisch: „Pentru noi, romanistica a fost, așa cum am învățat-o de la Coșeriu, catalizatorul care ne-a dezvăluit problemele și metodologia lingvisticii romanice și generale". 
Cea de-a III-a secțiune a volumului, intitulată sugestiv Evocări (p. 388-451), este structurată în două subtitluri. Primul - Mărturisiri și reconstituiri - îi are ca semnatari pe Valentin Mândâcanu, Un homo scientificus ajuns pe Olimp, Nicolae Mătcaș, Colosul din Tübingen, Grigore Vieru, Două neîmplinite dorințe ale lui Eugen Coșeriu, Matilda Caragiu-Marioțeanu, Eugeniu Coșeriu - savantul și omul, Nicolae Saramandu, Intâlniri cu Eugeniu Coșeriu, Cornel Vîlcu, Axis! (Coșeriu, azi, în mine), KatsuhikoTanaka, Ce am învățat eu de la Coșeriu?, Maria Șleahtitchi, Coșeriu: „Prin faptul că sunt vă fac să fiți și voi”, Lorenzo Lenzi, De la Mihăileni spre lume. Eugeniu Coșeriu (1921-2002) la zece ani de la moarte, Eugen Munteanu, Eugen Coșeriu, așa cum l-am cunoscut, Nicolae Leahu, Eugeniu Coșeriu: portret din vitraliu.

În subtitlul al doilea - Reflecții despre „,modelul Coșeriu” - meditează Dumitru Irimia, Nadia Anghelescu, Nicolae Saramandu, Silviu Berejan, Luminița Fassel, Vladimir Beșleagă, Marius Sala, Stelian Dumistrăcel, Valentina Botnaru, Eugen Munteanu, Valentina Tăzlăuanu, Ioana Vintilă-Rădulescu, Aurel Codoban, Anatol Moraru, Donatella Di Cesare, François Rastier, Rudolf Windisch, Wolf Dietrich, Vincenzo Orioles.

A IV-a secțiune - Viața în imagini (p. 461-477) - înfățișează fotografii ale Maestrului, în anii copilăriei și ai adolescenței, imaginea părinților săi, imagini ale colegilor şi discipolilor săi etc. Ultimele două fotografii ni-l prezintă pe „extraordinarul învățător Roman Mândâcanu” împreună cu elevul său, Eugeniu Coșeriu, și bustul savantului din comuna de baștină, Mihăileni.

Incheie lucrarea scurte date despre Autorii volumului (p. 478-479).

Apariția volumului Eugeniu Coșeriu: vocația universalității, aprobat de Comisia de selecție pentru editarea cărții naționale și editat cu sprijinul Ministerului Culturii, Educației și Cercetării, constituie un eveniment editorial remarcabil în viața culturală de la noi (și nu numai) și încununează o colaborare fructuoasă, ce durează iată mai bine de 20 de ani între Facultatea de Litere a Universității bălțene și Întreprinderea Editorial-Poligrafică Știința.

O ultimă constatare vizează ținuta poligrafică deosebită a lucrării, care va ocupa, suntem convinși, un loc aparte în colecția Personalități notorii (ajunsă la cel de-al XII-lea volum), suscitând un interes pe potrivă din partea celor interesați de viața și opera celui care a fost Marele Eugeniu Coșeriu.

Galaction VEREBCEANU

Doctor în filologie, conferentiar cercetător

E-mail: gverebceanu@gmail.com

ORCID: https://orcid.org/0000-0002-0725-4893

Institutul de Filologie Română „Bogdan Petriceicu-Hasdeu” (Chișinău)

Notă: Articolul a fost realizat în cadrul proiectului de cercetare 20.80009.1606.01 Valorificarea ştiinţifică a patrimoniului lingvistic naţional în contextul integrării europene, Institutului de Filologie Română „B. P.-Hasdeu” al MECC. 

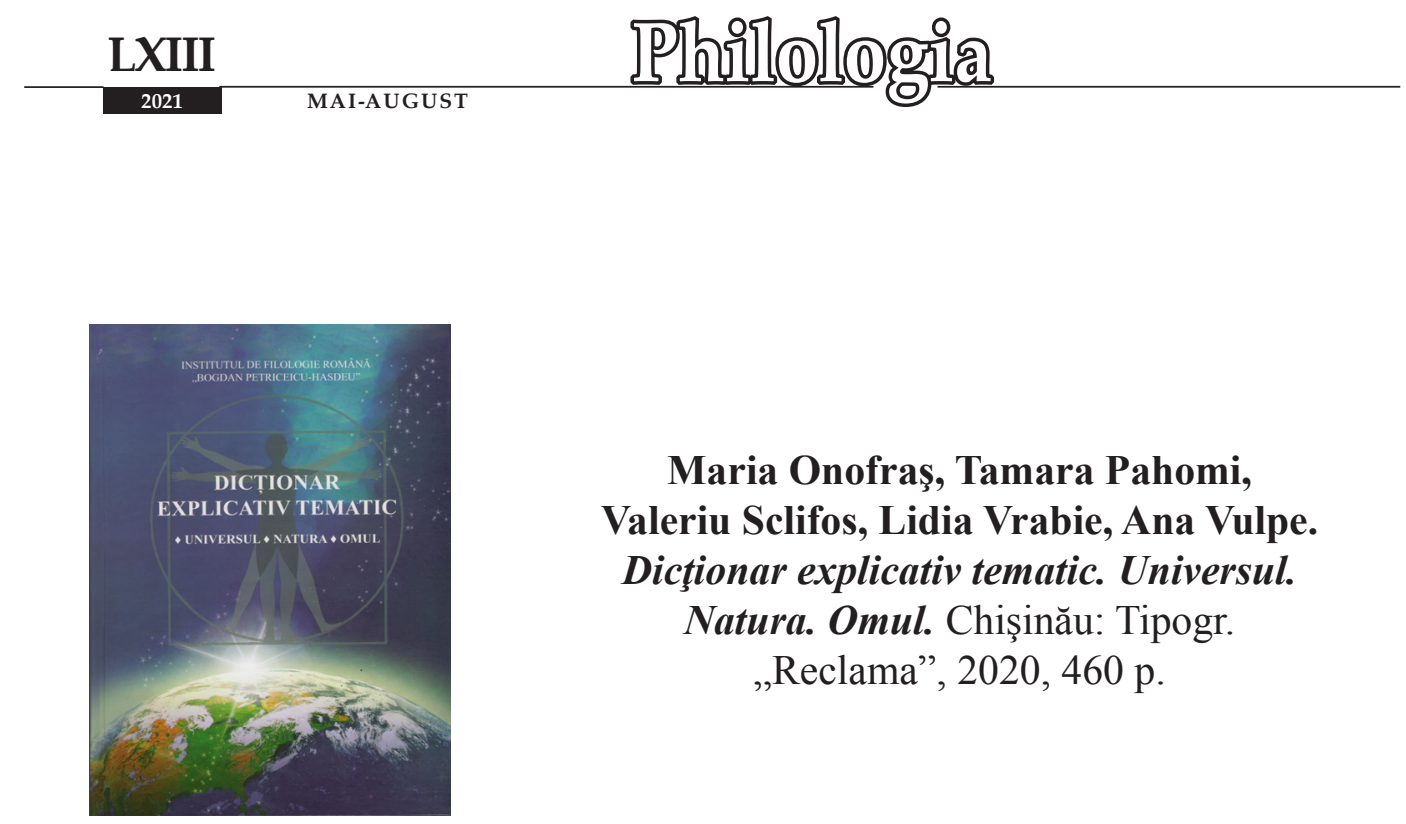

\author{
Maria Onofraş, Tamara Pahomi, \\ Valeriu Sclifos, Lidia Vrabie, Ana Vulpe. \\ Dicţionar explicativ tematic. Universul.
}

Natura. Omul. Chişinău: Tipogr.

„Reclama”, 2020, 460 p.

Dicţionarul explicativ tematic. Universul. Natura. Omul, ieşit de sub tipar la sfârşitul anului 2020, este unul original, singular, prin faptul că se înscrie într-o categorie de lucrări lexicografice mai rară, mai puţin cunoscută, mai puţin obişnuită cea a dicţionarelor ideografice. Tocmai de aceea este salutară apariţia lui.

Dicţionarul ca produs lexicografic tradiţional se asociază, de obicei, cu aranjarea în ordine alfabetică a cuvintelor care-i formează inventarul, deoarece această modalitate de prezentare a cuvintelor este cea mai răspândită. Se ştie însă că „ordinea alfabetică, deşi este practică, are un pronunţat caracter arbitrar”, mecanic şi izolează cuvintele unele de altele şi de ansamblurile lexicale din care fac parte (V. Bahnaru).

Unităţile de vocabular descrise în dicţionarul de faţă sunt grupate în baza unor noţiuni generice: UNIVERSUL, NATURA, OMUL. Optând pentru clasificarea noţională a cuvintelor, opusă celei alfabetice (semasiologice), autorii şi-au propus să reflecte raporturile dintre cuvinte, caracterul sistemic al lexicului, organizarea lui în câmpuri sau grupuri tematice. S-a adoptat, deci, perspectiva onomasiologică de abordare a vocabularului, căci pentru a realiza dicţionarul s-a pornit ,nu de la cuvânt în parte, ci de la noțiunea exprimată de acest cuvânt", după cum se menţionează în Prefaţă (p. 7). Implicând ideea de subordonare, câmpul sau grupul tematic reuneşte termenii în baza relaţiei hipero-hiponimice şi are capacitatea de a se ramifica în alte (sub)grupuri. Astfel, grupul tematic Corpul omenesc (p. 227-276) cuprinde grupurile Părţi ale corpului, Organe şi sisteme de organe, Procese fiziologice, Stări fiziologice, iar grupul Părţi ale corpului, de exemplu, este format, la rândul său, din subgrupurile Mâna, Piciorul, Degetele, Capul, Gâtul, Părul, Ochii, Dinţii, Scheletul.

Tot în Prefaţă se precizează că ,,principiul tematic de organizare a lexicului corespunde specificului de sistematizare a cunoştinţelor lingvistice în mintea omului" (p. 8). Vocabularul este într-adevăr considerat o „oglindă a realităţii”, funcţionarea sistemului lexico-semantic fiind determinată de caracterul sistemic al imaginii lumii, iar raporturile dintre elementele lexicale - de raporturile între obiectele şi 
fenomenele realităţii. În această ordine de idei, Dicţionarul explcativ tematic oferă o reprezentare, fie şi parţială, a imaginii conceptuale a lumii, exprimată prin mijloace lexicale. Dicţionarul cuprinde, ,într-o formulă redusă”, cele trei sfere conceptuale de bază: Universul, Natura, Omul, divizate în domenii şi subdomenii, care şi-au găsit reflectare şi în lucrări reprezentative pentru lexicografia ideografică europeană (F. Dornseiff. Der deutsche Wortschatz nach Sachgruppen. Berlin, 1933; J. Casares. Diccionario ideologico de la lengua espanola. Barcelona, 1959; R. Hallig, W. von Wartburg. Begriffssystem als Grundlage fur Lexigraphie. Berlin, 1963). Cu toate acestea, autorii dicţionarului au elaborat propria schemă ideografică, respectând „principiul ierarhiei şi cel al succesivităţii logice” (p. 8). Chiar dacă schema de clasificare a cuvintelor într-un dicţionar de acest tip, inclusiv în cel recenzat, poartă oarecum amprenta subiectivităţii autorilor, ea este rezultatul unui efort intelectual deosebit, determinat de necesitatea unei analize complexe şi minuţioase a raporturilor lexico-semantice existente între unităţile lexicale şi corelarea cât mai exactă a sistemului lexico-semantic al limbii cu imaginea conceptuală a lumii. Întrucât "lucrarea face parte din seria de dicţionare tematice de uz didactic" (p. 7), autorii au avut o sarcină în plus: aceea de a selecta temele şi unităţile lexicale corespunzătoare temelor, astfel încât să răspundă aşteptărilor publicului vizat în primul rând: profesori, elevi, studenţi, inclusiv alolingvi, ce studiază limba română. Stabilirea judicioasă a temelor, subtemelor, microtemelor, ,pornind de la unitatea lumii înconjurătoare, ca o totalitate a tot ce există" (p. 8), şi, totodată, de la necesităţile eventualilor utilizatori, identificarea elementelor lexicale uzuale din cadrul grupurilor tematice, volumul echilibrat al grupurilor în ansamblul lucrării sunt argumente ce ne îndreptăţesc să considerăm că autorii au găsit soluţia optimă pentru problemele capitale ale dicţionarului, cele privind schema de clasificare şi inventarul de cuvinte, fapt pentru care merită toată aprecierea.

Modul de prezentare a materialului, de definire a cuvintelor poartă marca şcolii lexicografice chişinăuiene, ce se distinge prin rigoarea principiilor aplicate la elaborarea dicţionarelor, în special a celor explicative. Astfel, toate definiţiile sunt de tip analitic; cuvintele-sinonime au definiţii similare (nefrític adj. Care ţine de rinichi; propriu rinichilor. Sin.: renal. renál adj. Care ţine de rinichi; propriu rinichilor. Sin.: nefritic. (p. 247); a asudá itr. A elimina sudoare prin porii pielii. Sin.: a transpira. a transpirá itr. A elimina sudoare prin porii pielii. Sin.: a asuda. (p. 251)); ţinându-se cont de caracterul normativ al lucrării, s-a indicat accentul şi categoria gramaticală a cuvintelor; în cadrul grupurilor cuvintele sunt repartizate după părţi de vorbire (substantive, adjective, verbe, uneori şi adverbe, numerale), apoi aranjate în ordine alfabetică. Observăm că, pentru a asigura comoditatea consultării dicţionarului, nu s-a renunţat totalmente la clasificarea alfabetică, la ea s-a recurs şi pentru întocmirea Indicelui de la sfârşitul lucrării, care serveşte la orientarea celor ce doresc să se informeze cu privire la vocabularul limbii române, pornind de la cuvânt spre noţiunea desemnată.

Aşadar, propunând, pe de o parte, descrierea lexicografică a unor subsisteme lexicale ca expresie a organizării structurate a vocabularului, respectând, pe de altă parte, principii riguroase de redactare, în concordanţă cu scopul urmărit, dicţionarul prezintă un vădit interes teoretic şi metodologic. 
Este evidentă şi valoarea practică a lucrării, din moment ce principiul onomasiologic care stă la baza elaborării ei corespunde punctului de vedere al vorbitorului şi ţine seama de necesităţile sale de comunicare (U. Ricken). Dat fiind faptul că în procesul comunicării interumane sunt abordate teme variate, clasificarea cuvintelor pe domenii de întrebuinţare se dovedeşte a fi deosebit de utilă. Utilizat în scopuri didactice, dicţionarul va servi drept sursă pentru o mai bună cunoaştere a vocabularului limbii române ca limbă maternă sau ca limbă străină şi realizarea unor sarcini de învăţare cât mai apropiate de situaţiile cotidiene, naturale de comunicare, conform paradigmei educaţionale actuale.

În final, ţinem să subliniem că Dicţionarul explicativ tematic. Universul. Natura. Omul denotă, fără tăgadă, competenţa celor care au trudit la elaborarea lui - un colectiv de lexicografi cu experienţă bogată în domeniu, care îşi adaugă în palmares o nouă lucrare valoroasă.

\section{Liliana POPOVSCHI}

Doctor în filologie

E-mail: lilianapopovschi@mail.ru

ORCID: https://orcid.org/0000-0002-7032-142X

Institutul de Filologie Română „Bogdan Petriceicu-Hasdeu”

(Chişinău)

Notă: Articolul a fost realizat în cadrul proiectului de cercetare 20.80009.1606.01 Valorificarea ştiinţifică a patrimoniului lingvistic naţional în contextul integrării europene, Institutului de Filologie Română „B. P.-Hasdeu” al MECC. 


\section{GaLaCtion VEREBCEANU - 70 de ani de la naștere}

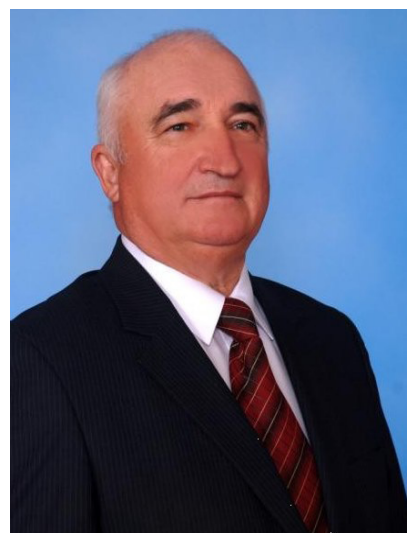

\section{Un vis cât o viață sau o viață de vis}

În după-amiaza unei zile fierbinți de vară, aflându-mă la biroul meu din Bălți, mă străduiam să dau conținut unor idei care, de la o vreme, mă frământau. Ceva însă nu se lega, iar muza nu-mi dădea târcoale. Căldura mare și dogoritoare de afară răzbătea prin pereții casei, făcând aerul din cameră greu respirabil. La un moment dat, simții cum o dulce moleșeală îmi învăluie tot corpul și, dintr-o dată, mă cufundai într-un somn adânc, cum arar mi se mai întâmpla.

$\mathrm{Nu}$ știu câtă vreme să fi dormit, dar mă trezii tot așa de ușor cum adormisem. Zăpușeala de afară slăbise, lăsând loc aerului răcoros al serii. Conștientizai atunci că tot ce văzui în somn nu era altceva decât un vis (dar ce vis!), care mi se fixă în minte în cele mai mici detalii și în care evenimentele se succedau cu o repeziciune uimitoare și într-o succesiune cronologică strictă, asemenea unui film bine regizat. Și, după cum toate cu noroc vin, la un interval de o zi, mă întâlnesc cu distinsa Doamnă Nina Corcinschi care, după ce i-am depănat pe îndelete visul, a venit cu inspirata idee de a face public această amintire afectivă proaspătă după trezire, despre septuagenarul Galaction Verebceanu. I-am mulțumit pentru sugestie cu condiția că acceptă să fie „,complice”: eu care îl cunosc pe omagiat de 43 de ani și ea care îl cunoaște și colaborează cu el cot la cot de peste 20 de ani.

Gh. P.

Se făcea că treceam prin vremuri plutind aidoma unui personaj al lui Mihail Bulgakov pe deasupra unor locuri necunoscute, în fața ochilor perindându-se mai multe așezări (sate, orașe) și numeroase chipuri cunoscute sau mai puțin cunoscute. De acolo, din înălțimi înregistram în minte tot ce vedeam. Alteori, 


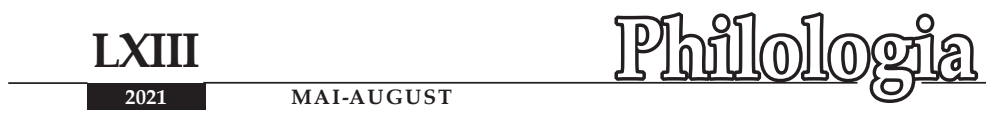

coboram printre eroii visului meu, conversând cu ei sau, pur și simplu, urmărindule tacit acțiunile lor.

Primul așa-zis popas a fost în localitatea Slobozia, Ștefan Vodă, despre care nu știam prea multe. Cunoșteam, bunăoară, că este locul de baștină al lui Galaction Verebceanu, un bun cunoscut de al meu și, fără a exagera, un prieten devotat, de care mă leagă mai multe amintiri luminoase, ce au trecut, cu timpul, în sentimente reciproce de amiciție. Așadar, am intrat, virtual, în casa soților Tatiana și Sava Verebceanu, care sărbătoreau modest, în cercul familiei lor, la o măsuță rotundă cu trei picioare, aniversarea a câțiva ani de la nașterea fiului Galaction. Privii la băiatul vioi și simpatic, purtător al unui nume extrem de rar, și constatai că seamănă leit cu mama sa, care, parcă ghicind mirarea și curiozitatea mea, declară că numele de botez, caracteristic unor fețe bisericești, i-a fost dat la insistența ei.

Așa cum clipele în vis durează fracțiuni de secundă, iată-l pe Galaction, după cei șapte ani de acasă, pășind în 1958 pragul școlii din satul natal și promovând clasă după clasă. Că elevul Galaction se deosebea prin niște aptitudini ieșite din comun, nu pot spune. Era un copil obișnuit, cum se întâmplă cu mai mulți copii de vârsta lui, vesel și nu o dată pus pe șotii. Într-o zi, continuă mama Tatiana, micul Galaction reveni în grabă de la școală și, de la poartă, strigă: „Mamă, mata știi cine-i bunicul nostru?” „Păi, cum să nu știu, bunicul nostru Vanea”. La care Galaction, contrariat că maică-sa nu știe nici atâta lucru, răspunse ferm: „Nu, mamă. Bunicul nostru e Lenin”. Mamă-sa îl fixă cu privirea și, schițând un zâmbet abia zărit în colțul buzelor, șopti, ca pentru sine: „Știu eu”. Zâmbii și eu și, de la realitatea zilelor noastre, m-am convins, nu o dată, ce efect dezastruos avea ideologia regimului sovietic asupra copiilor!

Mai aflai de la mama Tatiana că, de la o vârstă încă fragedă, Galaction își petrecea timpul citind, uneori în dauna temelor care erau însușite în grabă. Văzându-1 cu cartea în mâini, ea se bucura și aproba fără rezervă îndeletnicirea fiului său. Odată, sora mai mare, Ira, îl zări că citește pe furiș, lăsând la o parte manualele, și îl pârî: „Mamă, da' Galaction citește cărți de la bibliotecă”, convinsă că face un lucru folositor. Mama însă, care nu a fost dată la școală de mică (așa erau vremurile când fetele nu prea erau trimise la învățătură), răspunse mulțumită: „Bine că citește”.

$\mathrm{Nu}$ mult după absolvirea școlii medii este obligat, cum se obișnuia pe atunci (în 1968), să petreacă instruirea militară în rândurile forțelor armate sovietice. Cei trei ani de serviciu în termen, ca matelot pe un vas militar de tip distrugător, îmbâcsit cu armament de mare calibru, i-au părut o veșnicie, mai ales în primele luni. Dorul de părinți, de prietenii rămași acolo, de satul lui cel drag îl măcina neîncetat. Alinare își găsise în cititul cărților împrumutate de la biblioteca de pe vas, care aveau ca subiect frământările și suferințele personajelor provenite din mediul rural. O bucurie mare avu când descoperi printre rafturile de cărți romanul Ion de Liviu Rebreanu. Chiar dacă era o traducere în rusă, cititul îi producea o mare satisfacție, trăind și suferind împreună cu eroii cărții, de parcă se afla printre oamenii locului din satul lui cel scump. Lectura îi potolea oarecum dorul, ajutându-l să se adapteze mai ușor la regulile aspre ale vieții militare de pe corabie, la răul de mare, la expedițiile militare, de trei-patru luni, pe marea și oceanul cu valuri învolburate, care izbeau 
cu furie în bordul vasului, făcându-se auzit un scrâșnet îngrozitor de fiare. Când furtuna trecea, se întâmpla ca nava să acosteze în porturi străine, marinarii având permisiunea să viziteze, în grup a câte cinci persoane, orașele de coastă din țări ca Algeria, Cuba, Olanda, Norvegia.

După terminarea stagiului militar, îl aflăm pe tânărul Galaction Verebceanu la Facultatea de Litere a Universităţii de Stat din Moldova (în 1973). Am pășit alături de proaspătul student, trecând din aulă în aulă, din an în an, făcând cunoștință cu profesorii și colegii săi.

Cei cinci ani de studenție, ca și anii serviciului militar, îl transformară dintrun băiat timid și nehotărât în fața greutăților într-o persoană încercată și ambițioasă, care dovedea judecată adâncă și manifesta seriozitate și chibzuință. Probabil, aceste calităţi i-au determinat pe mai-marii Facultăţii să-l recomande pentru participare la concursul anunțat de Institutul, pe atunci, de Limbă și Literatură al Academiei de Științe. Odată cu ocuparea postului vacant (în 1978), începe o fază importantă în viaţa protagonistului nostru.

Aici firul evenimentelor trăite în vis încerc să-l împletesc cu momentele de viață ale eroului nostru, unele dintre acestea cunoscute și nouă. Așadar, preocupat să-și găsească un rost în activitatea de cercetare a Institutului, la îndemnul criticului literar Lazăr Ciobanu, Galaction Verebceanu face cunoștință cu niște manuscrise vechi păstrate la Muzeul de Literatură de la Uniunea Scriitorilor, luând primele lecții de documentare în scrierea chirilică de la L. Ciobanu. A urmat apoi (în 1982) sfatul Tatianei Iliașenco, șefa Sectorului de istorie a limbii, de a cerceta mai îndeaproape aspectul lingvistic al celei mai vechi versiuni românești a romanului popular Bertoldo, fiindu-i pus la dispoziție, prin bunăvoința istoricului literar Gheorghe Bogaci, o copie fotografică a manuscrisului aflat în arhiva Muzeului Istoric de Stat din Moscova. O deplasare de serviciu (şi nu una singură, cum s-a dovedit ulterior) în vederea consultării, pe viu, a exemplarului moscovit se impunea cu certitudine. Aceasta a fost cotitura determinantă de a se consacra cercetării şi editării textelor româneşti aparţinând epocii vechi, preocupare destul de rar întâlnită astăzi. Aplecat cu lupa în mână asupra manuscriselor provenind din timpurile vechi încerca să-și dea seama de valoarea fonetică pe care o ascundeau literele chirilice.

Dificultatea însușirii grafiei chirilice consta în faptul că limba română a folosit, timp de aproximativ cinci secole, alfabetul chirilic, care a fost creat, în primul rând, pentru o limbă slavă. Preluat însă de limba română pentru a reda structura sa fonetică, alfabetul chirilic se prezenta, după o expresie plastică a lui Al. Rosetti, asemenea unei haine rău împrumutată și rău adaptată limbii române, deoarece dispunea de mai multe semne grafice decât avea nevoie limba română și, în același timp, avea puține slove pentru a reda unele sunete specifice limbii române. De acest detaliu esențial Galaction Verebceanu și-a dat seama când a pornit pe un teren puțin sau chiar deloc bătătorit, fiind în întregime un autodidact în problema deloc simplă de a pătrunde în adâncurile scrierii vechi românești. Tocmai din aceste considerente, de la aprobarea oficială a temei pentru teza de doctorat și până la susținerea publică a ei, a trecut un timp destul de lung.

Primul rod al cercetării în domeniu a fost ediția critică intitulată Viața lui Bertoldo. Un vechi manuscris românesc. Studiu filologic, studiu lingvistic, ediție 


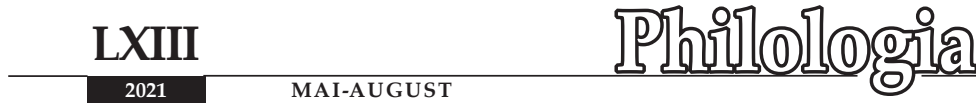

de text și indice de cuvinte de Galaction Verebceanu (Chișinău: Museum, 2002). Lucrarea este consacrată editării și cercetării celei mai vechi variante românești a romanului popular de origine italiană pătruns în literatura noastră în a doua jumătate a secolului al XVIII-lea.

În studiul filologic sunt examinate probleme privind originea şi circulaţia legendelor care au stat la baza cărţii lui Giulio Cesare Croce della Lira, descrierea manuscrisului, datarea manuscrisului, opinii asupra manuscrisului, localizarea manuscrisului şi chestiuni de filiaţie. Studiul lingvistic este consacrat cercetării aprofundate a fenomenelor de limbă la nivel grafic, fonetic, morfologic, sintactic, lexical şi al formării cuvintelor.

Textul propriu-zis al manuscrisului conţine transcrierea celei mai vechi versiuni românești a romanului popular Viața lui Bertoldo. În acest scop a fost aleasă metoda de prezentare, în paralel cu transcrierea, a filelor manuscrisului reproduse prin fotocopiere. În subsolul paginii se află aparatul negativ al ediţiei, ce cuprinde două secţiuni. În prima dintre ele au fost semnalate greşelile de scriere, modificările, grafiile insolite, precum şi diferenţele de natură fonetică, morfologică, sintactică sau lexicală privitoare la manuscrisul moscovit și versiunea Bertoldo secolul al XIX-lea (ms. BAR 1759). Comentariile lui G. Verebceanu pe marginea construcțiilor lingvistice ale textului, a paternității acestora, a perspectivei diacronice, care a modelat receptarea, a contextului în care a apărut manuscrisul, deopotrivă cu prezentarea facsimilelor, reactualizează o epocă, ne pun la dispoziție un pattern cultural, vorbesc despre continuitate și durată în limbă, literatură și cultură. Aflăm, din studiul cercetătorului nostru cât de mult întâmplările picante, seva vitală a dialogului, încărcătura sugestivă şi substratul ironic al discursului din romanul Viaţa lui Bertoldo au inspirat folclorul românesc, pătrunzând şi în basmele noastre.

Se încheie volumul cu un indice de cuvinte, ce cuprinde toţi termenii - comuni şi proprii - prezenţi în textul romanului popular Viaţa lui Bertoldo.

Despre importanța ediției, redutabilul profesor universitar bucureștean Gheorghe Chivu scria în prefața volumului: „Cercetare filologică temeinică, întreprinsă cu acribie şi bazată pe o bună cunoaştere atât a literaturii de specialitate, cât şi a stadiului atins de limba noastră de cultură la mijlocul secolului al XVIIIlea, volumul elaborat de Galaction Verebceanu va putea fi utilizat cu deplin profit de toţi cei interesaţi de vechiul scris românesc, deopotrivă istorici ai limbii literare şi istorici ai literaturii. El argumentează fără dubiu calitatea şcolii filologice din Chişinău şi pune încă o dată în evidenţă rolul pe care Institutul de Lingvistică din acest oraş şi l-a asumat în valorificarea ştiinţifică a cărţii vechi româneşti ajunse pe teritoriul fostei Uniuni Sovietice".

A urmat o perioadă (de paisprezece ani) în care Galaction Verebceanu ocupă funcția de secretar științific al Institutului de Lingvistică (din 2000). În acest răstimp colegii au avut de învățat de la Galaction Verebceanu lecția migalei întru perfecțiune. Atenția pentru detaliu, documentarea riguroasă, consecvența cu principiile și valorile în care crede, grija pentru corectitudinea de orice fel - lingvistică, administrativă, umană - sunt înscrise în scenariul comportamental și ființial al colegului nostru. 
Revine însă în curând la preocuparea sa preferată și participă la concursul inițiat și finanțat de Ministerul Educației, Culturii şi Cercetării al Republicii Moldova privind Programul pentru editarea cărții naționale. Câștigă acest concurs și depune la Întreprinderea de Stat Firma Editorial-Poligrafică Tipografia Centrală manuscrisul lucrării intitulate Alexandria chișinăuiană de la 1790. Un vechi manuscris românesc. Introducere filologică, studiu lingvistic, facsimile și ediție de text de Galaction Verebceanu, (Chișinău, 2016). E vorba de una din numeroasele versiuni ale romanului popular Alexandria, copie practic nestudiată și puțin cunoscută în mediul specialiștilor. Importanța ediției critice rezidă în faptul că reunește pentru prima dată în paginile unui volum atât reproducerea facsimilată a manuscrisului păstrat în străinătate (Institutul de Manuscrise al Bibliotecii Naţionale a Academiei de Ştiinţe „V. I. Vernadsky” din Kiev), dublată de transliterarea în română, conform metodei interpretative, a textului chirilic, cât și analiza temeinică a aspectului lingvistic (grafie, fonetică, morfologie, sintaxă, lexic, formarea cuvintelor), faptele de limbă fiind cercetate sub raportul stadiului atins de limba română din a doua jumătate a secolului al XVIII-lea.

Menționăm că aceste două volume de incontestabilă factură academică sunt elaborate cu o acuratețe de invidiat, devenind, din momentul apariției lor, lucrări de referință, permițandu-ne totodată să constatăm fără putință de tăgadă că, la ora actuală, Galaction Verebceanu e cel mai profund cunoscător și, în același timp, subtil și unic cercetător în Republica Moldova al istoriei limbii române vechi.

În prezent, Galaction Verebceanu este interesat de cercetarea unui manuscris al romanului popular intitulat Sandipa, păstrat la Biblioteca de Stat a Rusiei sub cota 824 (fondul Grigorovici) și datat în a doua jumătate a secolului al XVIII-lea.

Mai precizăm, de asemenea, că Galaction Verebceanu a participat la două proiecte științifice internaționale. Primul, Limba română vorbită în Moldova istorică, la care au luat parte cercetători de la Universitatea din Leipzig, Universitatea „Al. I. Cuza” din Iaşi, Universitatea de Stat „Alecu Ruso” și Institutul de Lingvistică al AŞM (1996-1999), și al doilea, Limbă şi identitate... asistat de cercetători de la Universitatea din Leipzig, Universitatea de Stat din Moldova, Institutul de Lingvistică al AŞM, Universitatea din Cernăuţi, Universitatea din Kiev (2003-2006). Rezultatele înregistrate sub forma unor studii au fost incluse în cele trei volume colective internaţionale: (ed.) Klaus Bochmann, Vasile Dumbrava, Limba română vorbită în Moldova istorică, vol. II, Texte, 2000; vol. I, Contribuții, Leipziger Universitätsverlag, 2002; Klaus Bochmann, Vasile Dumbrava (Hrsg.), Sprachliche Individuation in mehrsprachigen Regionen Osteuropas. I. Republik Moldova, Leipziger Universitätsverlag, 2007.

Portretul omagiatului nostru nu ar fi conturat suficient, dacă nu am aminti aici de modul cum își manifestă atitudinea disprețuitoare faţă de incompetenți și impostori; de delicatețea cu care te ,pescuiește” când comiți vreun lapsus linguae; de privirea rebelă când cineva debitează falsități despre limba română, identitate și conștiință națională, bilingvism; de harul humuleștean și zâmbetul șarmant de a povesti snoave și istorioare din viața de toate zilele; de patima pentru muzica populară românească autentică și pentru lectură; de obstinația de a evita camerele 
de luat vederi și de a nu se complace în umbra multelor lucrări bine făcute; de spiritul gospodăresc pe care îl ,,materializează” cu satisfacție pe lotul din jurul casei de vacanță.

Acestea fiind, după părerea noastră, reperele marcante ale biografiei celui care este Galaction Verebceanu, dr. în filologie, cercetător științific coordonator al Institutului de Filologie Română „Bogdan Petriceicu-Hasdeu”, nu ne rămâne decât să-i urăm, la cei 70 de ani, multă sănătate, realizări în sfera de activitate care și-a ales-o conștient și, deopotrivă, mulți ani înainte, voie bună și liniște sufletească alături de cei dragi și, nu în ultimul rând, alături de înțeleapta-i soție Valentina.

La mulţi ani!

Nina CORCINSCHI, Institutul de Filologie Română „B. P.-Hasdeu”, Chișinău

Gheorghe POPA, Universitatea de Stat „Alecu Russo” din Bălți 


\title{
PHILOLOGIA
}

\author{
2021, nr. 2 (314), p. 1-140 \\ https://doi.org/10.52505/1857-4300.2021.2(314)
}

\section{Descrierea CIP a Camerei Naționale a Cărții}

Philologia, 2021, LXIII, nr. 2 (314), 140 p./ Institutul de Filologie Română „B. P.-Hasdeu”; Redactori-șefi: Viorica Răileanu, Marian Gheorghe Simion, Chișinău: „PRO LIBRA” SRL. ISSN 1857-4300, E-ISSN 2587-3717.

Tiraj 150 ex. 
